\title{
Efeito de agentes anti-hiperestésicos à base de oxalato de potássio na permeabilidade da dentina humana. Estudo in vitro.
}

\section{Angela Destéfani Segala}

Tese apresentada à Faculdade de Odontologia de Bauru, da Universidade de São Paulo, como parte dos requisitos para obtenção do título de Doutor em Odontologia, área de Dentística. (Edição Revisada)

Orientador: Prof. Dr. J osé Carlos Pereira 


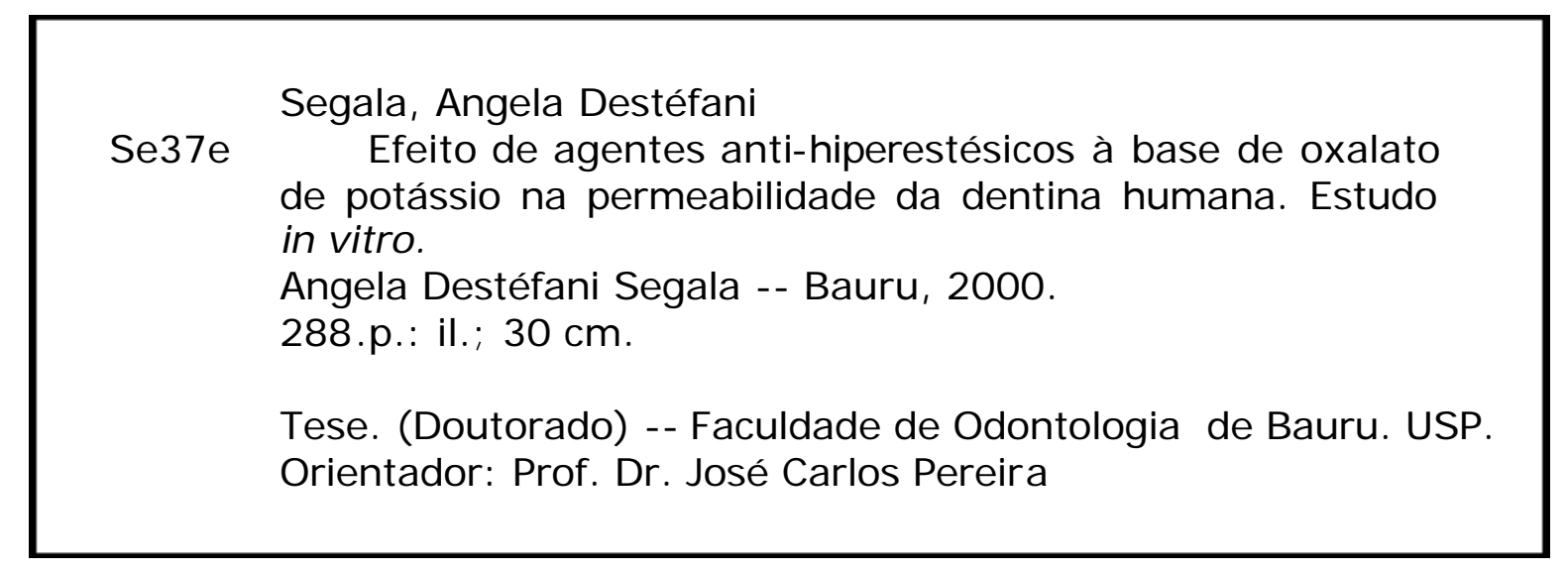

Autorizo, exclusivamente para fins acadêmicos e científicos, a reprodução total ou parcial dessa Tese, por processos fotocopiadores e/ou meios eletrônicos.

Assinatura do autor(a): 


\section{Angela Destéfani Segala}

3 de maio de 1966

Curitiba, PR.

Angelo Segala Neto

Nilza Destéfani Segala

1984-1988

1990

1993-1996

$1995-2000$

Associações
Nascimento.

Filiação.

Curso de Graduação em Odontologia, na Universidade Federal do Paraná.

Curso de Especialização em Dentística, pela PROFIS, na Faculdade de Odontologia de Bauru da Universidade de São Paulo.

Curso de Pós-Graduação em nível de Mestrado, área de Dentística, na Faculdade de Odontologia de Bauru da Universidade de São Paulo.

Curso de Pós-Graduação em nível de Doutorado, área de Dentística, na Faculdade de Odontologia de Bauru da Universidade de São Paulo.

$$
\begin{aligned}
& \text { ABO - Associação } \begin{array}{c}
\text { Brasileira de } \\
\text { Odontologia, Secção Paraná. }
\end{array} \\
& \text { GBPD - } \begin{array}{c}
\text { Grupo Brasileiro de Professores de } \\
\text { Dentística. }
\end{array} \\
& \text { IADR - Internation Association for Dental } \\
& \text { Research. } \\
& \text { SBPqO - Sociedade Brasileira de Pesquisas } \\
& \text { Odontológicas. }
\end{aligned}
$$




\section{Dedico esse trabalho ao Professor J osé Carlos Pereira}

Professor de capacidade incontestável,
capaz de fermentar o ambiente científico,
que ao aliar talento profissional, humildade
e um incansável esforço diário,
direciona nossos caminhos ao ensino e à pesquisa,
estimula e faz nascer professores e pesquisadores,
cumprindo sua missão e
concretizando a cada dia a dedicação de uma vida.

Homem de pureza de espírito que somente os sábios possuem; autêntico, honesto, idealista, desprendido de vaidades e preconceitos;

sua coerência de palavras e atitudes

Ihe permitem conduzir com firmeza e equilíbrio tudo o que faz; sua postura discreta e confiável refletem o ser humano que é.

\footnotetext{
Ao Professor

que me recebeu como um livro de páginas em branco pronto para ser escrito, ofereceu sua experiência e conhecimento, apoiou, confiou, investiu e me fez crescer.

Ao Ser Humano pelas palavras de incentivo que me fizeram caminhar mais leve, pela convivência que me fez uma pessoa melhor.
} 


\title{
Agradeço especialmente
}

\author{
A meus pais, Angelo e Nilza \\ E ao meu irmão, Marcos \\ que mesmo tão longe \\ e por tanto tempo, \\ nunca deixaram \\ sentir-me só, \\ garantindo meus ideais \\ e meus sonhos, \\ arejando meu caminho, \\ me incentivando \\ e me impedindo de fraquejar.
}




\section{Agradeço também}

À Regina, amizade que supera a distância;

ao J oão, companheiro;

à Simone, presença tranqüila;

Aos amigos do curso de Doutorado em Dentística:

Adriana, Cecília, Fátima, J oão, Margareth, Renata e Rogério

pelos caminhos que juntos
andamos,

sonhos.

Aos colegas dos cursos de Pós-Graduação

pelo companheirismo e pela cumplicidade

pelos momentos agradáveis

Aos funcionários e amigos da Pós-Graduação,

Ana, Aurélio, Cleusa, Débora, Giane, Heloísa, Neide,

pela presteza com que desempenham suas funções,

pela maneira afetuosa com que sempre me trataram,

participando comigo desses anos de curso

de maneira agradável e alegre,

tornando mais amenos os meus dias de pós-graduanda.

tudo seria incompleto sem a presença de vocês. 


\section{levarei uma recordação eterna...}

\section{Agradeço ainda}

À Faculdade de Odontologia de Bauru, por intermédio de seu Diretor Professor Aymar Pavarini, do seu Vice-Diretor Professor Clóvis Monteiro Bramante, pelas condições fornecidas para a realização deste curso.

À Comissão de Pós-Graduação da Faculdade de Odontologia de Bauru, na pessoa de seu Presidente Professor Luiz Fernando Pegoraro, pela atuação junto às causas da Pós-Graduação.

Ao Departamento de Dentística, através de seus funcionários que sempre me atenderam com atenção fornecendo suporte técnico e, em especial, aos docentes que me proporcionaram a possibilidade de sedimentar conhecimentos e de valorizar a pesquisa e a carreira docente.

À Associação dos Pós-Graduandos, aos funcionários Salvador e André, pela atenção e presteza com que sempre me atenderam.

Aos Funcionários do Serviço de Biblioteca e Documentação da FOB, pela maneira atenciosa e solícita com que desempenham suas funções.

Ao Professor José Mondelli, pela oportunidade que dá aos pósgraduandos, oferecendo sua experiência e liderando de maneira ímpar tudo que o cerca.

À Professora Maria Fidela de Lima Navarro, pela mulher forte e determinada que é em prol das causas acadêmicas.

Ao Professor Aquira I shikiriama, pelo homem amável e justo que se revelou escondido sob o manto de um professor sério, de poucas palavras.

Ao Professor Carlos Eduardo Francischone, pelo exemplo de dinamismo e versatilidade nas atividades profissionais.

Ao Professor Reinaldo Mazzotini, pela gentil e essencial coleta de dentes para a realização dessa pesquisa.

Aos Professores Elliot Kitajima e Breno Leite, pela disponibilidade com que ofereceram a infra-estrutura de seu laboratório, e ao Professor Mário Góes, pelo auxílio na realização das imagens microscópicas. 
Ao Professor José Roberto Lauris, pela orientação e realização criteriosa da análise estatística.

Ao Professor José Mauro Granjeiro, pela maneira entusiasmada e competente com que buscava respostas para esclarecer nossas dúvidas.

Aos profissionais do CCDM - Centro de Caracterização e Desenvolvimento de Materiais, pelo auxílio na execução dos ensaios de microscopia eletrônica de varredura e difração de raios $X$.

Ao Rubens Kasuo Kato, pelo cuidado na programação visual da capa desse trabalho.

À Professora Eloisa Maria Pagani Pereira e ao Professor Valdir J oão Afonso, pelas correções gramaticais e ortográficas.

À FAPESP - Fundação de Amparo à Pesquisa do Estado de São Paulo, pelo apoio financeiro durante o desenvolvimento do Curso de Pós-Graduação.

\section{A todos que contribuíram para a conclusão desse curso e dessa etapa da minha vida...}

Muito obrigada. 


\section{Sumário}

Lista de Abreviaturas e Símbolos......................................................................................

Lista de Figuras...................................................................................................

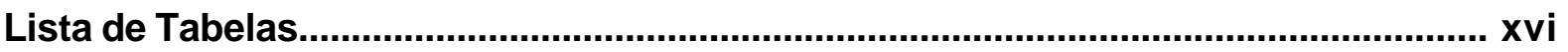

Lista de Gráficos............................................................................................................. xviii

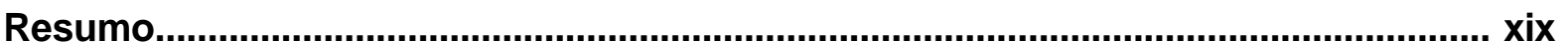

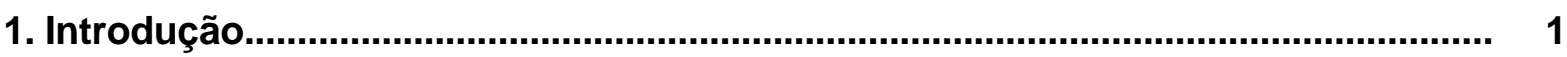

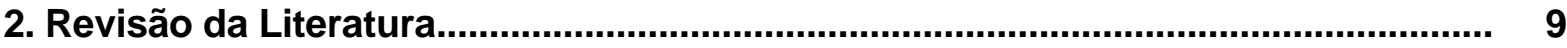

2.1. Terminologia e Definição.......................................................................... 10

2.2. Incidência e Prevalência.............................................................................. 11

2.3. Etiologia............................................................................................... 11

2.4. Diagnóstico da Hiperestesia Dentinária.......................................................... 14

2.5. Morfologia, Permeabilidade e Hiperestesia Dentinária........................................ 16

2.6. Mecanismos da Hiperestesia Dentinária......................................................... 22

2.7. Tratamento da Hiperestesia Dentinária - histórico............................................ 26

2.8. Mecanismos de Ação das Terapias e Agentes Anti-hiperestésicos....................... 28

2.8.1. Agentes de Ação Antiinflamatória.......................................................... 29

2.8.2. Despolarização das Terminações Nervosas............................................. 30

2.8.3. Agentes de Efeito Oclusivo sobre os Canalículos Dentinários.................... 31

2.9. Dessensibilização Natural e a Smear Layer........................................................ 54

2.10. Estudos Clínicos....................................................................................... 57

2.10.1. Hiperestesia Dentinária................................................................ 57

2.10.2. Permeabilidade Dentinária............................................................... 65

2.11. Estudos de Permeabilidade Dentinária in vivo............................................. 70

2.12. Estudos de Permeabilidade Dentinária in vitro................................................ 73

2.12.1. Métodos Quantitativos de Permeabilidade Dentinária............................. 73

2.12.1.1. Câmara para Medição da Permeabilidade Dentinária................... 75

2.12.1.2. Cálculos de Condutividade Hidráulica (Lp)............................... 75

2.12.1.3. Espécimes.............................................................................. 76

2.12.1.4. Seleção, Armazenamento e Tempo Pós-extração.......................... 81

2.12.1.5. Obtenção dos Discos de Dentina................................................ 83

2.12.1.6. Permeabilidade Mínima (smear layer) ....................................... 84

2.12.1.7. Permeabilidade Máxima (limpeza com ácido) ............................. 86

2.12.1.8. Direção de Filtração................................................................ 89

2.12.1.9. Pressão Pulpar e Pressão Hidrostática...................................... 90

2.12.1.10. Estudos de Condutividade Hidráulica, In Vitro .......................... 92

2.12.1.11. Estudos do Coeficiente de Permeabilidade, In Vitro, por Difusão 122

2.12.1.12. Estudos do Coeficiente de Reflexão, In Vitro.............................. 126 
2.12.2. Métodos Qualitativos de Permeabilidade Dentinária - MEV, EDS e XDS.. 127

2.12.2.1. Estudos Laboratoriais de Microscopia Eletrônica de Varredura.... 130

3. Proposição.

4. Material e Métodos. 139

4.1. Ensaios de Condutividade Hidráulica.................................................................... 140

4.2. Ensaios de Microscopia Eletrônica de Varredura...................................................... 156

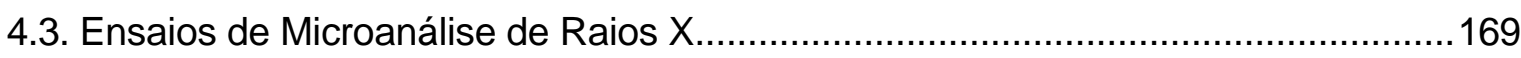

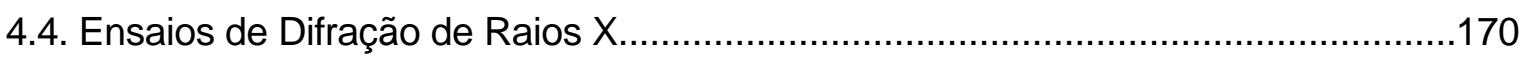

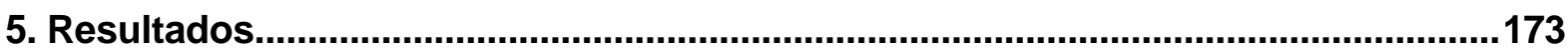

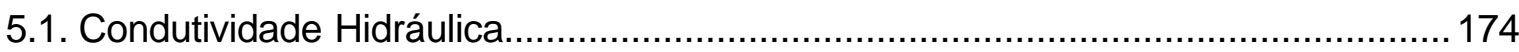

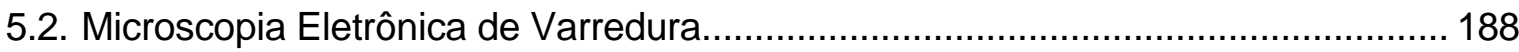

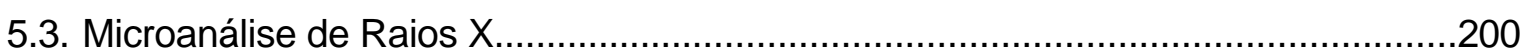

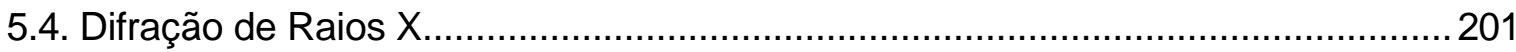

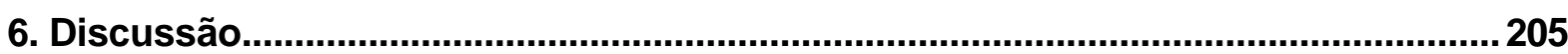

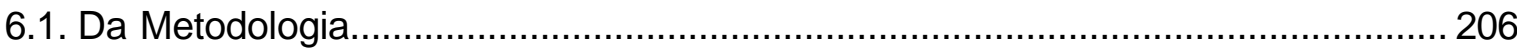

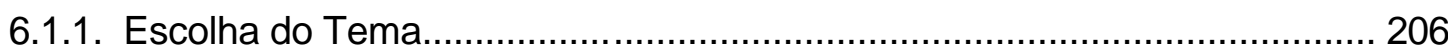

6.1.2. Escolha dos Materiais......................................................................... 208

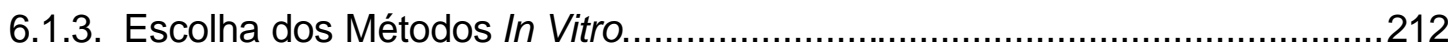

6.1.3.1. Condutividade Hidráulica........................................................... 215

6.1.3.2. Microscopia Eletrônica de Varredura............................................222

6.1.3.3. Microanálise de Raios X ............................................................ 230

6.1.3.4. Difração de Raios X............................................................ 231

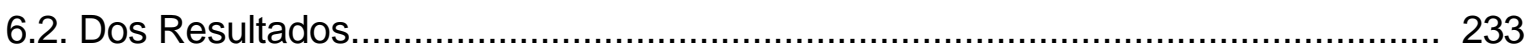

6.2.1 Condutividade Hidráulica....................................................................... 233

6.2.2. Microscopia Eletrônica de Varredura.......................................................... 244

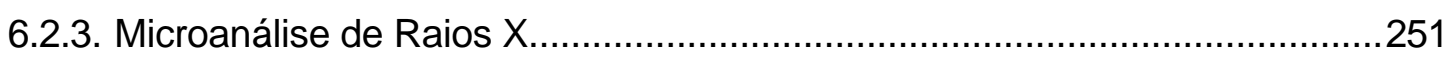

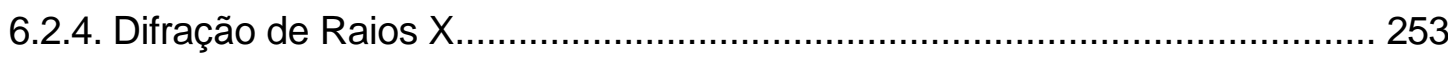

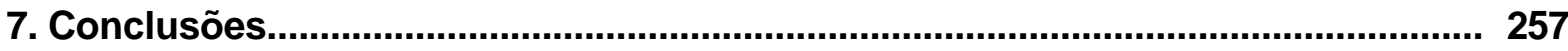

Referências Bibliográficas .................................................................................261

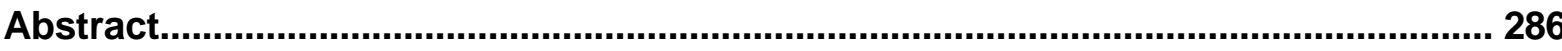




\section{Abreviaturas e Símbolos}

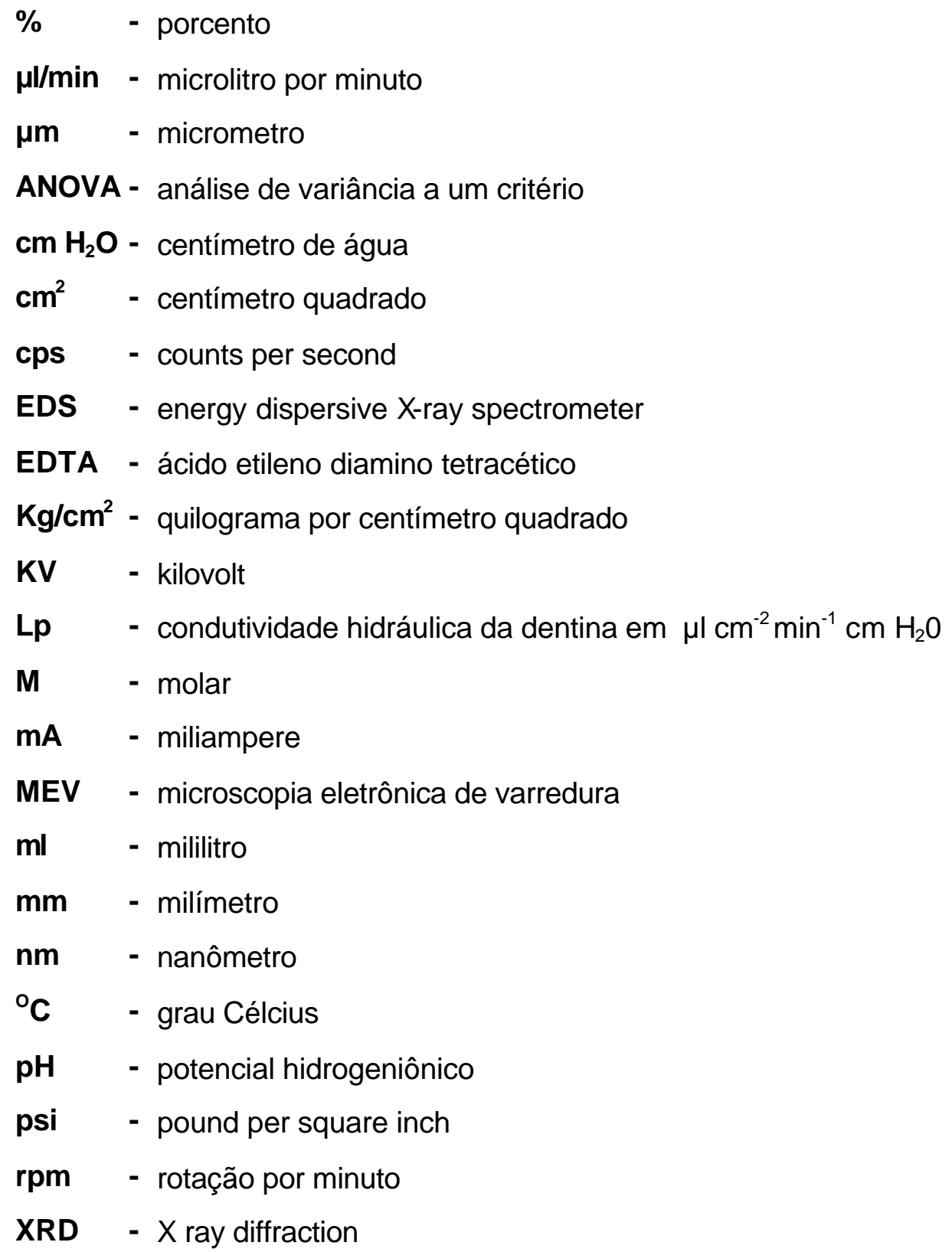

XRD - X ray diffraction 


\section{Lista de Figuras}

Figura 1 - Resumo dos mecanismos anti-hiperestésicos. Os túbulos dentinários abertos (à esquerda) permitem que forças hidrodinâmicas estimulem mecanorreceptores causando dor. A dessensibilização pela oclusão tubular (à direita) pode restringir o movimento do fluido, diminuindo a dor. A criação da smear layer é efetiva como uma camada equivalente de precipitados cristalinos (à esquerda). A dessensibilização pelo bloqueio da atividade nervosa (à direita), não interfere com o movimento do fluido, mas reduz a resposta nervosa. Os sais de potássio eugenol são exemplos desse tipo de dessensibilização ${ }^{164}$

Figura 2 - A - Fotomicrografia de um túbulo dentinário de uma área hiperestésica. 0 lúmen do túbulo está repartido por estruturas membranosas; B - Imagem da estrutura membranosa forrando o túbulo dentinário de um área hiperestésica ${ }^{282}$

Figura 3 - A - Fotomicrografia de um túbulo dentinário em área espontaneamente dessensibilizada. Cristais romboédricos de 0,1 a $0,3 \mu \mathrm{m}$ estão presentes; B - Imagem de amplos depósitos cristalinos no lúmen do túbulo dentinário de uma área espontaneamente dessensibilizada ${ }^{282}$

Figura 4 - Sistema hidráulico utilizado para avaliar a pressão pulpar in vivo ${ }^{42}$

Figura 5 - Desenho esquemático mostrando o disco de dentina e a câmara de filtração utilizada em diversos trabalhos ${ }^{81,135,142,143,186,190,192,193,217,248,249}$

Figura 6 - A - Dentina tratada com oxalato de potássio a $30 \%$, revelando cristais de oxalato de cálcio que coincidem com o tamanho dos túbulos dentinários; B - Penetração dos cristais de oxalato de cálcio nos túbulos dentinários; C - Dentina tratada com oxalato, mostrando extensões do material ligando os cristais de oxalato de cálcio às paredes dos túbulos ${ }^{81}$

Figura 7 - Desenho esquemático do dispositivo utilizado por muitos autores para a medição da condutividade hidráulica da dentina, in vitro. O movimento da bolha de ar através da câmara representa o índice de fluido que filtra através da dentina. A micro-seringa permite o ajuste da posição da bolha de $\operatorname{ar}^{196,194}$

Figura 8 - Esquema do aparato utilizado para medir a permeabilidade dentinária como condutividade hidráulica, introduzida por Pashley e Galloway, em 1985, utilizada no presente estudo e por muitos outros autores $141,183,184,213,214,227,237$

Figura 9 - A - Aparência homogênea e amorfa da smear layer controle; B - Remoção da smear layer pelo ácido cítrico a $6 \%$, revelando os orifícios tubulares ${ }^{181}$.. 103

Figura 10 - A - Smear layer tratada com oxalato dipotássio a $30 \%(\mathrm{pH} 7)$ por dois minutos. Nota-se a formação de cristais amplos e irregulares; B - Smear layer tratada com oxalato dipotássio a $30 \%$ por dois minutos, seguida por desafio ácido. $O$ condicionamento removeu 0 material amorfo $\mathrm{e}$ homogêneo ao redor dos cristais maiores ${ }^{181}$ 
Figura 11 - A - Smear layer tratada com oxalato de potássio a 3\% (pH 2) por dois minutos. Nota-se que a superfície é formada por grânulos mais finos; B superfície tratada com oxalato de potássio a $3 \%(\mathrm{pH} 2)$ por dois minutos, seguida pelo desafio com ácido cítrico. Nota-se pouca mudança na superfície $^{181}$

Figura 12 - A - Smear layer tratada com oxalato dipotássio a $30 \%$ por dois minutos, seguido do tratamento com oxalato de potássio a $3 \%$. Observa-se a superfície dentinária coberta por cristais heterogêneos; B - Desafio com ácido cítrico a $6 \%$ por dois minutos. Notam-se poucas modificações na superfície ${ }^{181}$

Figura 13 - A - Sistema adaptado para a utilização de segmentos coronários. Ao invés da câmara de filtração, utilizou-se uma placa de plexiglass e um tubo de aço que interliga a câmara pulpar e o sistema de microcapilares ${ }^{75,85,145,161,179,180,198,200,213,214,215,239,253,255}$; B - Disco de dentina adaptado sobre uma depressão cônica na plataforma de plexiglass para avaliação qualitativa da permeabilidade dentinária ${ }^{161}$

Figura 14 - Constatação das diferenças regionais de permeabilidade em discos de dentina $^{162}$

Figura 15 - Demonstração esquemática dos espécimes radiculares e de como foram adaptados na câmara de filtração ${ }^{61,63}$

Figura 16 - Desenho esquemático do dispositivo utilizado para medir a evaporação de água da dentina ${ }^{13}$

Figura 17-Diagrama mostrando como o fluxo de líquido é medido através do dispositivo Flodec, capaz de detectar alterações lineares mínimas do movimento da bolha de $\operatorname{ar}^{169,286}$

Figura 18 - Fotomicrografia da superfície dentinária após 20 aplicações de Butler Protect. Notam-se muitos cristais na superfície e no interior dos túbulos ${ }^{146}$.. 134

Figura 19 - A - Dentina tratada com Therma-Trol (solução de oxalato de potássio); B Dentina tratada com Therma-Trol, imersa em saliva artificial e submetida a escovação $0^{104}$

Figura 20 - A - Terceiro molar extraído, fixado na base de resina, pronto para ser acoplado à máquina de corte; $\mathbf{B}$ - Remoção da porção radicular através de um corte aproximadamente na altura do teto da câmara pulpar; C - Corte paralelo ao primeiro, removendo o esmalte oclusal para a obtenção dos discos de dentina; D - Máquina de corte ISOMET utilizada para a confecção dos discos de dentina; E - Diagrama mostrando a localização aproximada do disco de dentina na porção coronária do dente. Notar sua posição imediatamente acima dos cornos pulpares; F - Discos de dentina após o acabamento das superfícies, com aproximadamente $1 \mathrm{~mm}$ de espessura, livres de remanescentes de esmalte e de cornos pulpares. 
Figura 21 - Desenho esquemático do sistema para medição da permeabilidade dentinária como condutividade hidráulica (Lp), adaptado de Pashley e Galloway, em 1985, com seus componentes: cilindro de nitrogênio, câmara de pressão, micro-seringa e capilar de vidro com a bolha de ar, câmara de filtração com o disco de dentina.

Figura 22 - A - Desenho esquemático dos componentes da câmara de filtração: compartimentos superior e inferior, espaçadores e anéis de borracha; $\mathbf{B}$ Disco de dentina posicionado sobre o espaçador no compartimento inferior da câmara de filtração; C - Espaçador do compartimento superior adaptado sobre o disco de dentina, mostrando a área da superfície dentinária onde foram realizados os testes.

Figura 23 - Bolha de ar no interior do capilar de vidro, sobre a régua milimetrada, acompanhando o deslocamento do líquido através do disco de dentina...........

Figura 24 - Confecção de canaletas na superfície pulpar, com broca esférica, direcionando a fratura para permitir a análise da espessura do disco.

Figura 25 - Desenho esquemático do disco de dentina delimitado conforme a seqüência de experimentos executada.

Figura 26 - A - Desenho esquemático do disco de dentina fraturado de acordo com a orientação das canaletas, mostrando as áreas da superfície e da espessura da fratura de cada etapa da seqüência experimental; B Fragmentos do disco de dentina após ter sido desidratado e fraturado.

Figura 27 - Fragmentos externos do disco de dentina, montados no porta-amostra de alumínio e recobertos com ouro, para serem analisados no microscópio eletrônico de varredura.

Figura 28 - Histograma de cores (à esquerda), imagem original (acima, à direita) e o resultado da segmentação utilizando tons de cinza para definir as áreas desobstruídas dos túbulos dentinários (abaixo, à direita)...

Figura 29 - Visualização da imagem das áreas não obstruídas dos túbulos dentinários identificados automaticamente pelo computador.

Figura 30 - Os cálculos efetuados são apresentados numa planilha que fornece uma variedade de informações sobre as áreas delimitadas no histograma.

Figura 31 - Etapas da seqüência experimental executada: A-imagem característica da smear layer. Nota-se mínima área desobstruída demarcada com a cor verde; $\mathbf{B}$ - situação da dentina limpa com EDTA, cuja desobstrução canalicular foi também demarcada com verde; C-regiões em azul representando as áreas desobstruídas após o tratamento da dentina com um dos materiais anti-hiperestésicos estudados; $\mathbf{D}$ - regiões desobstruídas após o desafio com ácido cítrico, delimitadas em vermelho......

Figura 32 - Medição da profundidade alcançada pelos cristais, a partir da superfície, no interior dos túbulos. 
Figura 33 - A - Aparelho de difração de raios X utilizado nas análises; B - destaque da parte interna do aparelho onde foram depositadas as amostras para receberem o bombardeamento de raios $X$

Figura 34 - Imagens microscópicas da seqüência experimental executada com o material Oxa-Gel: A-imagem da smear layer simulada com lixas; Baparência da dentina limpa com EDTA; $\mathbf{C}$ - aspecto da dentina tratada com Oxa-Gel. Observam-se cristais obstruindo as embocaduras dos túbulos dentinários; D - após o desafio com ácido cítrico a $6 \%$, percebe-se a remoção parcial dos cristais da superfície, permanecendo aqueles localizados nas embocaduras tubulares; E-imagem dos cristais de oxalato de cálcio acomodados no interior dos túbulos dentinários após a ação do Oxa-Gel na superfície da dentina; F - não se observam, nesse espécime, modificações no padrão de obstrução intra-tubular após o desafio ácido

Figura 35 - Imagens microscópicas da seqüência experimental executada com o material Experimental 1: A - smear layer simulada in vitro; $\mathbf{B}$ - remoção da smear layer após o condicionamento com EDTA; $\mathbf{C}$ - aspecto da superfície da dentina tratada com 0 agente Experimental 1, obstruindo completamente as aberturas tubulares; D - pequenas modificações foram notadas após o desafio com ácido das superfícies tratadas; E - cristais puderam ser vistos no interior dos túbulos tratados com o Experimental 1; F - o ácido cítrico não modificou o padrão obstrutivo dos túbulos tratados com esse material.

Figura 36 - Imagens microscópicas da seqüência experimental executada com o material Experimental 2: A - aspecto amorfo e homogêneo característico da smear layer; B-remoção completa da smear layer após o condicionamento com EDTA; $\mathbf{C}$ - aspecto da superfície da dentina tratada com o agente Experimental 2, obstruindo as aberturas tubulares com formações cristalinas de diferentes tamanhos; D - após o desafio ácido, percebe-se que a maior parte das partículas menores foram removidas, e os cristais maiores permaneceram obstruindo as aberturas tubulares; E presença de cristais no interior dos túbulos aglomerados com remanescentes do material; F - após a ação do ácido cítrico, os cristais ainda puderam ser observados intratubularmente.

Figura 37 - Imagens microscópicas da seqüência experimental executada com o material Gel Fluoretado: A - dentina coberta pela smear layer; B - limpeza da superfície após o condicionamento com EDTA; C-aspecto da superfície da dentina tratada com o Gel Fluoretado, mostrando a ausência de cristais e o pequeno poder obstrutivo do material; D - o desafio ácido não modificou o padrão da superfície em relação ao da dentina tratada, observando-se apenas a superfície livre dos remanescentes do material; E - os pequenos cristais de fluoreto de cálcio puderam ser vistos no interior dos túbulos tratados com o Gel Fluoretado, formando uma espécie de tampão; F - esse material não mostrou boa resistência ao desafio com ácido cítrico, apesar de ainda serem vistos cristais no interior dos túbulos... 199 
Figura 38 - A - aparência da smear layer cristalizada devido à reação com o oxalato de potássio; B - no espécime fraturado, notam-se densos smear plugs no interior dos túbulos dentinários impedindo a penetração dos cristais depositados nas embocaduras

Figura 39 - Aspecto da dentina após ter sido limpa com EDTA a 0,5 M. Percebe-se a ausência da smear layer superficial revelando as embocaduras tubulares desobstruídas e eventuais resíduos dos smear plugs no interior dos túbulos.

Figura 40 - Dentina acidificada com EDTA e não lavada, previamente à aplicação do oxalato de potássio. Percebe-se o aspecto granuloso da superfície, sugerindo a permanência dos produtos da dissolução da centina pelo ácido

Figura 41 - Precipitações cristalinas derivadas da reação dos géis à base de oxalato de com o substrato dentinário: A-cristais com formato romboédrico e contorno definido são formados pela reação do material Oxa-Gel com a dentina; B - percebe-se a forma mais globular dos cristais formados pelo material Experimental 1; $\mathbf{C}$-precipitação característica do material Experimental 2, mostrando cristais romboédricos envoltos por estruturas semelhantes a resíduos do gel

Figura 42 - Aparência da dentina tratada com o Gel Fluoretado: A-superfície dentinária e as aberturas tubulares livres de cristais, mostrando um massa amorfa circundando as embocaduras; $\mathrm{B}$-massa amorfa aderida às paredes dos túbulos fraturados, na região próxima à embocadura, sugerindo resíduos do material 


\section{Lista de Tabelas}

Tabela 1 - Distribuição da amostragem conforme os materiais anti-hiperestésicos e as diferentes formas de pré-tratamento superficial estudados nos ensaios de condutividade hidráulica.

Tabela 2 - Ficha para o registro dos dados obtidos nos ensaios de condutividade hidráulica e respectivos cálculos de Lp e percentagem.

Tabela 3 - Distribuição dos materiais e seqüência experimental utilizados nos ensaios de microscopia eletrônica de varredura....

Tabela 4 - Distribuição da amostragem nos ensaios de difração de raios X, relacionando os agentes anti-hiperestésicos estudados e os espécimes em forma de disco ou pó de dentina.

Tabela 5 - Comparações intragrupos da condutividade hidráulica da dentina, expressas em percentagem, após tratamento com o Oxa-Gel, considerando as condições de pré-tratamento (Duncan, $p<0,05$ ).

Tabela 6 - Comparações intragrupos da condutividade hidráulica da dentina, expressas em percentagem, após tratamento com o material Experimental 1 , considerando as condições de pré-tratamento (Duncan, $p<0,05$ ).......... 178

Tabela 7 - Comparações intragrupos da condutividade hidráulica da dentina, expressas em percentagem, após tratamento com o material Experimental 2 , considerando as condições de pré-tratamento (Duncan, $p<0,05$ ).

Tabela 8 - Comparações intragrupos da condutividade hidráulica da dentina, expressas em percentagem, após tratamento com o Gel Fluoretado, considerando as condições de pré-tratamento (Duncan, $p<0,05$ ).

Tabela 9 - Diferença entre os valores médios de filtração, em percentagem, na presença da smear layer e após o tratamento com os materiais, e entre o tratamento com os materiais e o desafio ácido, sob os diferentes prétratamentos da dentina (Duncan, $\mathrm{p}<0,05$ ).

Tabela 10 - A - Efeito dos agentes anti-hiperestésicos na condutividade hidráulica da dentina, em percentagem, com relação ao pré-tratamento da superfície (Duncan, $p<0,05$ ).

B - Efeito do pré-tratamento da superfície na condutividade hidráulica da dentina, em percentagem, com relação aos agentes anti-hiperestésicos (Duncan, $p<0,05$ )

Tabela 11 - Comparação intergrupos da condutividade hidráulica da dentina, em percentagem, após diferentes pré-tratamentos de superfície (Duncan, $p<0,05)$

Tabela 12 - Comparações intragrupos das áreas desobstruídas dos túbulos dentinários, expressas em percentagem (média e desvio-padrão Duncan, $p<0,05)$. 
Tabela 13 - Diferença entre os valores médios de áreas não obstruídas dos túbulos dentinários, em percentagem, nas diferentes etapas do experimento (Duncan, <0,05).

Tabela 14 - A-Efeito dos agentes anti-hiperestésicos na obstrução dos túbulos dentinários, independentemente das condições analisadas, em percentagem de área não obstruída (Duncan, $p<0,05$ ). B - Percentagem de área desobstruída dos túbulos dentinários na seqüência experimental, independentemente do agente anti-hiperestésico (Duncan, $p<0,05$ ).

Tabela 15 - Profundidade de precipitação dos cristais mínima, máxima e média após o tratamento da dentina com os diferentes agentes anti-hiperestésicos

Tabela 16 - Comparação entre os dados obtidos através dos experimentos de condutividade hidráulica e das imagens de microscopia eletrônica de varredura para os 4 materiais anti-hiperestésicos, sob a condição de prétratamento da dentina seca com ar.

Tabela 17 - Percentagem dos elementos químicos encontrados após o tratamento da dentina com os agentes anti-hiperestésicos, através da microanálise semiquantitativa de raios $X$.

Tabela 18 - Distribuição dos compostos químicos encontrados nos discos de dentina tratados com os agentes anti-hiperestésicos, conforme a condição da superfície e o tempo de aplicação, através de testes de difração de raios X 203

Tabela 19 - Distribuição dos compostos químicos encontrados na dentina pulverizada tratada com os agentes anti-hiperestésicos, conforme o tempo de aplicação, através de testes de difração de raios $X$

Tabela 20 - A - Ordenação dos materiais experimentais, do melhor para o pior, em função das diferenças de filtração comparativamente a smear layer e ao desafio ácido.

B - Ordenação das condições de pré-tratamento, da melhor para a pior, em função das diferenças de filtração comparativamente a smear layer e ao desafio ácido

Tabela 21 - Seqüência dos materiais frente aos condições de pré-tratamento que produziram as menores diferenças, em ordem crescente, entre os parâmetros A - smear layer e material e, também, B - material e desafio ácido

Tabela 22 - Comparação entre as médias percentuais obtidas após a aplicação dos materiais na dentina seca com ar, conforme a seqüência experimental, analisadas através dos ensaios em microscopia eletrônica de varredura e de condutividade hidráulica. 


\section{Lista de Gráficos}

Gráfico 1 - Valores médios de filtração, em percentagem, na presença da smear layer, após o tratamento com o Oxa-Gel e após o desafio ácido, sob os diferentes pré-tratamentos da dentina (Duncan, $p<0,05$ ).

Gráfico 2 - Valores médios de filtração, em percentagem, na presença da smear layer, após o tratamento com o material Experimental 1 e após o desafio com ácido cítrico, sob os diferentes pré-tratamentos da dentina (Duncan, $p<0,05)$...........

Gráfico 3 - Valores médios de filtração, em percentagem, na presença da smear layer, após o tratamento com o material Experimental 2 e após o desafio ácido, sob os diferentes pré-tratamentos da dentina (Duncan, $p<0,05$ ).

Gráfico 4 - Valores médios de filtração, em percentagem, na presença da smear layer, após o tratamento com o Gel Fluoretado e após o desafio ácido, sob os diferentes pré-tratamentos da dentina (Duncan, $p<0,05$ ).

Gráfico 5 - Médias percentuais de filtração proporcionadas pelos agentes antihiperestésicos nos diferentes pré-tratamentos da superfície de dentina (Duncan, $p<0,05$ ).

Gráfico 6 - Médias percentuais de filtração dos agentes anti-hiperestésicos em relação aos pré-tratamentos superficiais da dentina (Duncan, $p<0,05$ ).

Gráfico 7 - Representação gráfica das médias percentuais de áreas não obstruídas após a execução da seqüência experimental, para cada material anti-hiperestésico (Duncan, $\mathrm{p}<0,05$ ).

Gráfico 8 - Representação gráfica das médias percentuais das áreas não obstruídas na presença da smear layer, após a aplicação do material anti-hiperestésico e após o desafio com ácido cítrico (Duncan, $p<0,05$ ).

Gráfico 9 - Representação gráfica das médias percentuais de áreas desobstruídas após a aplicação dos materiais experimentais, em relação a seqüência experimental (Duncan, $p<0,05)$......

Gráfico 10 - Comparação entre as médias percentuais obtidas após a aplicação dos materiais anti-hiperestésicos na dentina seca com ar, analisadas através dos ensaios em microscopia eletrônica de varredura e de condutividade hidráulica.

Gráfico 11 - Espectro de raios X, mostrando picos característicos dos elementos em níveis específicos de energia.

Gráfico 12 - Exemplo de espectro obtido nos ensaios de difração de raios X, identificando as fases cristalinas presentes nos espécimes analisados.

Gráfico 13 - Comparação entre as médias percentuais obtidas conforme a seqüência experimental, independentemente do material utilizado na dentina seca com ar, através dos ensaios em microscopia eletrônica de varredura e de condutividade hidráulica. (representação gráfica das Tabelas 10 e 14). 


\section{Resumo}

O oxalato de potássio tem sido utilizado no tratamento da hiperestesia dentinária através da precipitação de cristais de oxalato de cálcio intra e extracanaliculares, obstruindo os túbulos dentinários e reduzindo o deslocamento de fluido. O objetivo desse estudo foi analisar in vitro quantitativa e qualitativamente a permeabilidade da dentina tratada com três diferentes formulações à base de oxalato de potássio e um gel fluoretado, sob cinco diferentes pré-tratamentos superficiais. O grau de oclusão dos túbulos dentinários foi avaliado por meio de microscopia eletrônica de varredura, observando a precipitação cristalina, e pela medição da condutividade hidráulica da dentina após a aplicação dos agentes anti-hiperestésicos. A natureza dos elementos químicos que compõem os cristais e os compostos formados foram identificados por meio da microanálise de raios $\mathrm{X}$ e da difração de raios $X$, respectivamente.

Para o ensaio de condutividade hidráulica, realizado por meio de um dispositivo específico, foram preparados 200 discos de dentina com $1 \mathrm{~mm}$ de espessura, obtidos de terceiros molares humanos extraídos. Os espécimes foram divididos em 20 grupos de dez espécimes, correspondentes a três géis derivados do oxalato de potássio: Oxa-Gel, pH 4,10; Experimental 1, $\mathrm{pH} 4,02$; Experimental 2, $\mathrm{pH}$ 2,52, e um gel de fluoreto de sódio acidulado a $1,23 \%$ - Nupro (Dentsply) - pH 3,6 a 3,9. Esses materiais foram aplicados na dentina sob as seguintes condições de pré-tratamento: seca com ar; seca com papel absorvente; mantida molhada; acidificada e seca com ar; acidificada e seca com papel. Os ensaios foram realizados na seguinte seqüência experimental: na presença de smear layer; após condicionamento com EDTA $0,5 \mathrm{M}$, por um minuto; após a aplicação dos materiais-teste e após o desafio com ácido cítrico a 6\%, por um minuto.

Outros 40 discos de dentina foram selecionados para o estudo em microscopia eletrônica de varredura. Os espécimes foram divididos em quatro grupos de dez espécimes, correspondentes aos quatro agentes anti-hiperestésicos em experimentação. A superfície 
oclusal dos discos foi dividida em partes, onde foram executadas as quatro etapas da seqüência experimental. Os agentes anti-hiperestésicos foram aplicados na dentina seca com ar, a condição de pré-tratamento de melhor desempenho no teste de condutividade hidráulica. Os discos, após serem desidratados, foram fraturados e metalizados para a análise microscópica. A análise das imagens foi feita com o auxílio do programa ImageLab, que fornecia os valores percentuais das áreas não obstruídas/desobstruídas dos túbulos dentinários para cada condição estudada.

A microanálise de raios $\mathrm{X}$ foi realizada em oito discos de dentina, tratados dois a dois com um dos quatro agentes anti-hiperestésicos, após a superfície dentinária oclusal ter sido seca com ar. Os espécimes foram preparados da mesma maneira como foram o para microscopia eletrônica de varredura; entretanto, tiveram a cobertura condutora de carbono.

Para os ensaios de difração de raios $X$ foram preparados 18 espécimes em forma de disco de dentina e outros nove, de pó de dentina. Dezesseis dos discos de dentina foram tratados com os agentes anti-hiperestésicos na superfície seca com ar, após a remoção ou não da smear layer, durante 3 ou 12 minutos. Os outros dois espécimes serviram œmo controle, um com smear layer e outro limpo com EDTA. O pó de dentina foi misturado a cada um dos materiais experimentais e filtrado para a análise. Um espécime de pó sem tratamento também foi analisado e utilizado como controle.

A análise estatística dos dados fornecidos pelos ensaios de condutividade hidráulica e de microscopia eletrônica de varredura foi realizada por meio da análise de variância e do teste de Duncan $(\mathrm{p}<0,05 \%)$. Independentemente do pré-tratamento de superfície, o material Experimental 2 produziu valores de filtração significativamente menores e o Gel Fluoretado, os maiores. Em geral, a dentina seca com ar foi o pré-tratamento de melhor desempenho e significativamente diferente dos demais. A interação entre material e pré-tratamento de superfície mostrou valores similares de condutividade hidráulica para a maioria das combinações, mas o material Oxa-Gel sob a condição seca com ar mostrou melhor 
tendência para o decréscimo da filtração, e para resistência a desobstrução ao desafio ácido.

A análise microscópica das imagens mostrou que os géis à base de oxalato de potássio formaram precipitados cristalinos na embocadura e no interior dos túbulos dentinários com padrões estatisticamente semelhantes. O material com maior poder obstrutivo foi o Oxa-Gel, mesmo após o desafio com ácido cítrico. As superfícies dentinárias fraturadas, previamente tratadas com derivados do oxalato de potássio, mostraram cristais a uma profundidade média entre 7,52 e 9,41 $\mu \mathrm{m}$ no interior dos túbulos. O Gel Fluoretado mostrou raríssimas formações cristalinas apenas no interior dos túbulos.

A microanálise de raios $X$ da dentina tratada mostrou o cálcio, fósforo e oxigênio como os elementos mais encontrados nos espécimes. Na difração de raios $\mathrm{X}$, os espécimes em forma de disco de dentina mostraram -se mais reativos do que os em pó. Os compostos encontrados quando a dentina foi tratada com derivados do oxalato de potássio foram o oxalato de cálcio e o fosfato de cálcio potássio. O fluoreto de cálcio foi observado nos espécimes tratados com o Gel Fluoretado. Os agentes experimentais derivados do oxalato de potássio aplicados na dentina seca com ar têm potencialidade para o tratamento da dentina hiperestésica. 


\section{Introdução}

A efetividade de muitos agentes utilizados para o tratamento da hiperestesia dentinária, a elevada incidência clínica e a dificuldade de resolução deste problema têm induzido numerosos estudos utilizando um grande número de metodologias à procura da terapia mais eficiente.

As dificuldades no manejo da hiperestesia dentinária parecem iniciar-se com a própria terminologia empregada para expressar essa manifestação sensorial da dentina ${ }^{154,175.203}$. Encontram-se na literatura expressões como hipersensibilidade dental, sensibilidade dental, hipersensibilidade dentinária ou, simplesmente, sensibilidade dentinária. O termo hipersensibilidade é, entretanto, inapropriado já que mantém estreita relação com as manifestações imunológicas do organismo. Por outro lado, os termos sensibilidade e dental são demasiadamente genéricos para apontar a particularidade da condição estésica da dentina. Tem-se sugerido a expressão hiperestesia dentinária para diferenciar entre uma situação de extrema sensibilidade a um determinado estímulo aplicado à dentina, e a dor resultante de eventos de natureza patológica ${ }^{203}$. Hiperestesia dentinária foi a expressão empregada na seqüência deste trabalho e que, acredita-se, a que mais proximamente defina a condição estésica da dentina.

A hiperestesia dentinária pode ser definida como uma dor transitória a partir da dentina exposta, tipicamente em resposta aos estímulos químicos, térmicos, táteis ou osmóticos, os quais não podem ser explicados por qualquer outro defeito ou patologia dental $^{5,14,54,154,222,258}$. A prevalência dessa condição varia de um mínimo de $10 \%$ a um máximo de $20 \%^{9,44,67,154,241}$, dependendo do estudo e da população analisada. Pesquisas epidemiológicas indicaram que a maioria das superfícies hiperestésicas está na margem vertíbulo cervical de caninos e pré-molares $9,44,67,154,155,241$. Convém ressaltar que qualquer local da dentina exposta pode exibir hiperestesia, mas nem toda dentina exposta é 
hiperestésica $^{39}$, a exemplo do que ocorre em aproximadamente 10\% dos indivíduos, nos quais o esmalte e o cemento não se encontram, deixando uma região de dentina cervical exposta, mas não necessariamente hiperestésica ${ }^{274}$.

A dentina começa a acusar sensibilidade apenas quando exposta ao meio bucal, após a perda do esmalte e/ou do cemento, formando geralmente lesões não cariosas cervicais $^{34}$ originadas por erosão ${ }^{9,10,13,17,57,79,89,99,105,109,125,218,224,242,245,275,276}$, abrasão 11,21,22,54,77,78,99,216,226,228 , atrição $0^{67,119,225,226,259}$, abfração $22,82,119,120,203,276$. Também, vários autores têm apontado o tratamento periodontal como um mecanismo capaz de viabilizar a hiperestesia dentinária ${ }^{6,60,126}$. Entretanto, a etiologia das lesões dentárias cervicais é considerada multifatorial, apontando o trauma oclusal e a erosão como processos primários do aparecimento dessas lesões, coadjuvados por outras causas de natureza endógena e exógena 9, 21,22,34,67,82,83,119,123,203,241,259.

A hiperestesia dentinária pode ser confundida com condições clínicas que mostram a ocorrência de dor provocada pelos mesmos agentes, contudo, apresentam etiologias diferentes e variam em freqüência e severidade ${ }^{14,55,265}$. O diagnóstico da hiperestesia dentinária, segundo Curro, em $1990^{48}$, e corroborado por Pereira ${ }^{203}$, em 1995, deve coincidir com as seguintes características: dor localizada e aguda de origem não patogênica; perda de esmalte e/ou cemento; resposta variável aos estímulos térmicos, químicos e táteis; desaparecimento da dor com a remoção dos estímulos; controle com agentes antihiperestésicos e não deve haver evidência radiográfica de patologia apical ${ }^{48,203}$. Além disso, muitas vezes, a dor pode ser coincidente com o estado de ansiedade do paciente ${ }^{203,265}$.

Várias hipóteses têm sido sugeridas para explicar o mecanismo da hiperestesia dentinária, embora nenhuma delas leve a um perfeito entendimento de como os estímulos aplicados na superfície de uma dentina hiperestésica possam ser transmitidos para a polpa e provocar dor ${ }^{54,115,116,164,175,184,203}$. Há três teorias mais freqüentemente descritas para entender esse fenômeno: a Teoria das Terminações Nervosas, a Teoria Odontoblástica e a 
Teoria Hidrodinâmica. A primeira explica que são as terminações nervosas ou os nociceptores que respondem diretamente quando a dentina é estimulada e estão completamente localizadas na dentina. A segunda teoria sugere que os odontoblastos e seus prolongamentos, sendo química ou eletricamente relacionados aos nervos, atuariam como receptores dentinários, participando da iniciação e da transmissão de um estímulo. A terceira é a mais aceita e defende o envolvimento das terminações nervosas neurossensitivas próximas da polpa na condução impulso doloroso, estimuladas pelo mecanismo hidrodinâmico ${ }^{160}$.

A Teoria Hidrodinâmica da sensibilidade dentinária, originalmente postulada no século XIX e mais tarde desenvolvida por Brännström ${ }^{175,269}$, sugere que movimentos de deslocamento dos fluidos dentinários ou do conteúdo dos túbulos ocorrem em resposta ao estímulo tátil, térmico, químico ou osmótico ${ }^{8,25,26,31,32,66,72,107,160,209,222}$. O rápido deslocamento de fluido no sentido da polpa ou em sentido contrário promove alterações na pressão intrapulpar e a conseqüente estimulação das terminações nervosas causando dor. Assim, a presença de túbulos dentinários abertos em direção à polpa, devido à exposição dentinária por atrição, abrasão, erosão, abfração ou ainda recessão gengival, se torna o prérequisito para a hiperestesia dentinária ${ }^{27,112}$.

Com base no princípio da hidrodinâmica, qualquer diminuição no movimento do fluido pulpodentinário fatalmente leva a uma correspondente redução da hiperestesia dentinária ${ }^{164}$. Assim, o objetivo do tratamento da hiperestesia é promover a obliteração ou selamento dos túbulos dentinários por meio de agentes que interagem com a permeabilidade ou, mais precisamente, com a condutividade hidráulica da dentina ${ }^{54,274}$. Segundo Pashley ${ }^{164}$, em 1986, e Holland ${ }^{98}$, em 1994, a ação anti-hiperestésica pela oclusão tubular engloba uma variedade de agentes que atuam fisiológica ou patologicamente mais do que terapeuticamente. A hiperestesia dentinária pode ser reduzida, fisiológica ou patologicamente, pela formação de cálculo sobre túbulos hiperestésicos, formação de 
cristais intratubulares por meio do fluido dentinário ou de minerais salivares, formação progressiva de dentina peritubular (dentina esclerosada), invasão dos túbulos por bactéria, formação de cristais de cárie, formação intratubular de plugs de colágeno, infiltração de proteínas plasmáticas grandes para o interior dos túbulos e formação de dentina terciária ou reparadora. O tratamento terapêutico da dentina hiperestésica pode se dar pela produção de smear layer por escovação e etc., cobertura ou impregnação da dentina com material resinoso e pela obstrução dos túbulos dentinários por meio da aplicação tópica de fluoretos, oxalatos ou outras drogas com potencial obstrutivo.

Entretanto, alguns desses mecanismos podem ser impedidos por alimentos ácidos, bebidas ou organismos acidogênicos da placa dental. Os ácidos provavelmente dissolvem os depósitos superficiais, reabrindo os túbulos e restabelecendo o desequilíbrio hidrodinâmico $^{165}$. Portanto, não é difícil observar uma característica transitória da hiperestesia dentinária. Abertos, os túbulos dentinários expostos são, provavelmente, sensitivos, além de permitirem o transporte de substâncias da cavidade bucal para a polpa $^{175}$.

Apesar da hiperestesia não ser um fenômeno recente e nem raro, seu mecanismo ainda é pobremente entendido e, conseqüentemente, não se dispõe até o momento de um produto que preencha todos os requisitos de um agente anti-hiperestésico ideal, mencionados por Groosman ${ }^{84}$, em 1935. Além disso, tratar a hiperestesia sem estabelecer e controlar as causas primárias da degradação das estruturas mineralizadas do dente e sem a devida orientação do paciente seria uma tarefa mal sucedida a curto prazo ${ }^{203}$. Assim, os materiais anti-hiperestésicos podem ser classificados, de acordo com seu suposto mecanismo de ação, em agentes de ação antiinflamatória ${ }^{14,19,116,118,139,149,265}$, agentes que despolarizam as terminações nervosas ${ }^{4,12,93,94,95,113,164,238,258}$ e agentes de efeito oclusivo sobre os canalículos dentinários. Estes últimos podem atuar através da precipitação de 
proteínas, da deposição de partículas, da aplicação de uma película impermeabilizadora ou de procedimentos restauradores e, também, por intermédio da luz laser ${ }^{203}$.

A obliteração dos canalículos dentinários pela precipitação de proteínas é representada pela atuação do nitrato de prata $^{7,81,116,222,265}$ e da formalina ${ }^{4,81,84}$. A formação e deposição de partículas pode ser viabilizada principalmente pela brunidura ${ }^{84,184,20,204}$, pelo hidróxido de cálcio $^{28,80,81,122,138,139,183,264,265}$, também pelo cloreto de estrôncio ${ }^{7,68,81,110,133,236}$ e pelo fosfato de cálcio ${ }^{103,111,248,249,250,267,268,278}$, além dos

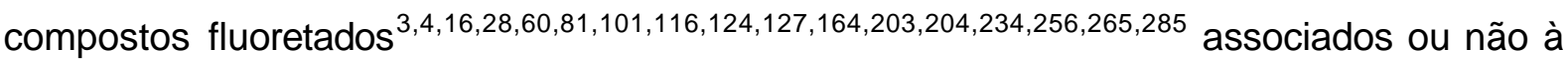
iontoforese $e^{64,65,81,137,203,229,265}$ e, em especial, pelo oxalato de potássio que se comporta tipicamente, obstruindo ou reduzindo o lúmen dos túbulos dentinários $46,56,59,70,81,88,91,104,112,113,141,142,143,144,145,150,160,164,168,174,179,181,184,201,203,205,207,2$ $12,217,220,237,248,270,277$

Os procedimentos adesivos agem oclusivamente pela impregnação das resinas fluidas $^{31,49,50,69,100,101,104,152,153,162,219,251,254,271,281,286}$, ou dos primers ${ }^{49,51,104,240,254,271}$ e, ainda, das restaurações com resinas compostas ${ }^{67,210,211}$ e com cimento de ionômero de vidro $^{23,40,223,45}$. A luz laser também é capaz de tratar a dentina hiperestésica através da deposição de partículas ${ }^{74,117,136,147,151,199,230,273,274,287}$.

O oxalato de potássio atende a vários requisitos de um agente anti-hiperestésico ideal e pode ser apresentado como sendo tipicamente uma droga de efeito oclusivo sobre a dentina, embora alguns autores tenham sugerido a possibilidade da sobreposição de um efeito neural ${ }^{91,129,164,207,113,150,202}$, caracterizando dois efeitos distintos na redução da hiperestesia dentinária, um imediato e outro mediato. O bloqueio dos túbulos por cristais caracteriza o efeito mediato e a despolarização neural, o efeito anti-hiperestésico imediato do oxalato de potássio ${ }^{150}$. 
O mecanismo de ação do oxalato de potássio através da obstrução ou redução do lúmen dos túbulos dentinários por meio da formação e deposição de cristais de oxalato de cálcio em presença de meio ácido, é corroborado tanto por estudos in vitro $^{81,104,144,168,174,179,181,237,277}$ quanto in vivo ${ }^{46,59,112,248,150}$. O efeito neural, defendido por $\mathrm{Kim}^{113}$, em 1986, Stead, Orchardson e Warren ${ }^{244}$, em 1996, Gillam et al. ${ }^{70}$, em 1996, e Peacock e Orchardson ${ }^{202}$, em 1999, deve-se à difusão do potássio através dos túbulos, aumentando a concentração deste íon extracelularmente, ao redor das terminações nervosas próximas ao limite pulpodentinário, onde altera as trocas normais de sódio e potássio essenciais para a transmissão do impulso nervoso, tornando-as imediatamente menos excitáveis.

O fluoreto de sódio é um dos compostos mais largamente utilizados desde 1941, quando Lukonsky ${ }^{127}$ acreditou que poderiam ser empregados no tratamento da hiperestesia dentinária, apesar das pesquisas mostrarem resultados conflitantes. Enquanto alguns autores como Krauser $^{116}$, em 1986, acreditam que o uso dos fluoretos como agentes antihiperestésicos é encorajador, outros ${ }^{28,203,234}$ crêem, como Pashley ${ }^{164}$, em 1986, que apesar do fluoreto de sódio agir formando cristais de fluoreto de cálcio, especialmente na embocadura dos túbulos dentinários, proporciona um bloqueio insuficiente para impedir completamente a transmissão do estímulo pelo mecanismo hidrodinâmico. Além disso, o fluoreto de cálcio é um composto bastante instável e parece se dissolver facilmente em um ambiente aquoso, fazendo com que o efeito anti-hiperestésico dos fluoretos seja, via de regra, de curta duração 6,60,203,265,285. Apenas uma pequena fração dos fluoretos aplicados sobre a dentina é retida sobre a forma insolúvel de fluorapatita ${ }^{60,116,203,256,285}$.

Uma variedade de pesquisas clínicas e laboratoriais tem sido desenvolvida para desvendar essa pouco compreendida, porém dolorosa condição dentinária. Os estudos clínicos caracterizam-se pela dificuldade de execução e subjetividade, especialmente quanto aos métodos de mensuração da dor ${ }^{71,87,97}$. Os estudos laboratoriais englobam as pesquisas 
relacionadas à permeabilidade dentinária realizados em animais, in vivo, contribuindo com os experimentos que não podem ser realizados em humanos ${ }^{128,167,170,172,173,182,192,277}$. Os estudos in vitro, envolvem a preparação de espécimes dentinários subseqüentemente avaliados quantitativa e qualitativamente por uma diversidade de técnicas. Em qualquer das situações, entretanto, trabalham-se com variáveis e situações diferentes da dinâmica e da complexidade da fisiologia dentinopulpar.

Como a maior parte das formulações que reduzem a hiperestesia dentinária o fazem por cristalização no interior e na embocadura dos túbulos, reduzindo a movimentação do fluido dentinário, esta pesquisa visa contribuir com informações qualitativas e quantitativas sobre o efeito de agentes derivados do oxalato de potássio e do fluorfosfato de sódio acidulado no padrão obstrutivo dos túbulos dentinários. 


\section{Revisão da Literatura}




\section{Revisão da Literatura}

\subsection{Terminologia e Definição}

Os termos utilizados na literatura para designar a manifestação sensorial da dentina exposta são de natureza bastante variável ${ }^{175}$, e por isso não há, até o momento, uma terminologia universalmente aceita ${ }^{154}$. Os termos sensibilidade e hipersensibilidade, dental ou dentinária, são freqüentemente encontrados. O termo dental é inapropriado por ser demasiadamente genérico para apontar a particularidade da condição estésica da dentina ${ }^{203}$. A sensibilidade dentinária é uma resposta normal à dentina exposta, ao passo que a hipersensibilidade dentinária pode significar uma sensibilidade excessiva, uma manifestação imunológica do organismo ${ }^{265}$. Para Damante*, hiperestesia é um termo que mais especificamente define uma sensibilidade excessiva e dolorosa a um determinado estímulo. Diferencia-se de hipersensibilidade, que é a qualidade do organismo vivo de reagir com dor a eventos de natureza patológica ${ }^{203}$. O termo hiperestesia dentinária foi também sugerido por Pereira ${ }^{203}$, em 1995, para traduzir a sensação dolorosa da dentina a um determinado estímulo que não a cárie dental.

A hiperestesia dentinária é freqüentemente definida como sendo uma resposta exagerada ou uma dor transitória relacionada à exposição da dentina a estímulos químicos, táteis, térmicos ou osmóticos provenientes do meio bucal, os quais, normalmente, não causariam resposta em um dente saudável, sem evidência de outro defeito ou patologia $3,14,54,154,222,258$. Essa exposição pode ser resultante da perda de esmalte por processos de abfração, atrição, erosão ou abrasão e, também, por desnudamento da superfície radicular por recessão gengival ou tratamento periodontal. A dor, conseqüência da exposição dentinária, possui intensidade variável nos diferentes dentes e indivíduos,

\footnotetext{
*Damante, J. H. - Comunicação pessoal
} 
estando, ainda, diretamente relacionada ao grau de tolerância e aos fatores emocionais de cada paciente ${ }^{203}$.

\subsection{Incidência e Prevalência}

Estudos demonstram que a hiperestesia dentinária afeta entre 10\% e 20\% da população, sendo a prevalência similar em várias partes do mundo Pode acometer qualquer dente, porém, é mais comum em caninos e pré-molares, ocorrendo quase que invariavelmente na face vestibular ${ }^{9,44,67,154,241}$. Verificaram também, clinicamente, a semelhante predisposição à hiperestesia dentinária entre os $\operatorname{sexos}^{9,39,67,241}$, e, ainda, a alta prevalência em pacientes tratados periodontalmente ${ }^{39}$.

\subsection{Etiologia}

A dentina em condições normais, recoberta pelo esmalte na região correspondente à coroa dentária e pelo cemento na porção radicular dos dentes, não é hiperestésica. Esses elementos naturais de proteção não mostram sensibilidade aos estímulos próprios da cavidade bucal. Dessa forma, a dentina começa a acusar algum grau de hiperestesia somente quando exposta ao meio bucal, após o desgaste dessas estruturas de proteção, principalmente na região da junção amelocementária. Entretanto, em aproximadamente $10 \%$ dos indivíduos, o esmalte e o cemento não se encontram, e uma área de dentina cervical permanece exposta, mas não, necessariamente, hiperestésica ${ }^{274}$.

A perda das estruturas dentárias por lesões não cariosas pode ser causada por, erosão, abrasão, atrição, abfração ou pela associação desses fatores. É considerada abrasão a perda de substância dentária por ação mecânica como, por exemplo, a escovação dos dentes. Considera-se como erosão a perda de estrutura dentária decorrente de um processo químico ou idiopático, sem a presença de bactérias ${ }^{57}$. Por outro lado, atrição é entendida como o desgaste fisiológico das superfícies dentárias pela ação 
funcional e parafuncional da mastigação, como conseqüência do contato dente a dente $^{67,120,203,225,259}$. E, ainda, denomina-se a abfração, a perda patológica de tecido duro de uma região do dente distante da atingida por forças biomecânicas ${ }^{82}$.

Como se vê, a patologia das lesões dentárias cervicais é considerada multifatorial ${ }^{9,22}$ e pode ser explicada à luz de algumas teorias. A teoria da erosão química explica como vários tipos de ácidos, presentes em alimentos, drogas e bebidas, podem descalcificar o esmalte. Essas substâncias têm origem exógena e provêm de dietas ricas em ácidos orgânicos ou de refrigerantes, muitos dos quais contêm ácidos inorgânicos ${ }^{79,125,224}$.

Também a regurgitação, associada a doenças que provocam distúrbios gastrintestinais, pode contribuir para o aparecimento de ácidos na boca. Nessas condições, os ácidos, de natureza endógena, podem resultar de estados de bulimia ou anorexia nervosa $^{89}$ e que, associados a distúrbios salivares, levam à exacerbação das lesões ${ }^{9,13,105,125,242,245,275,276}$. As lesões produzidas pela ação dos ácidos mostram perda de estrutura dentária ampla e sem bordas definidas ${ }^{119}$, dando à lesão um aspecto de pires. Nos pacientes com distúrbios na alimentação, como é o caso dos bulímicos e anoréxicos, os vômitos constantes, provocados ou espontâneos, acabam por dissolver o esmalte e posteriormente a dentina principalmente na superfície lingual dos dentes superiores, deixando-as planas, lisas e sem brilho. Em ambas as situações, a freqüente acidez da cavidade bucal produzida pelos vômitos e regurgitações, associada à xerostomia e à diminuição da capacidade tampão da saliva, levam à dissolução das estruturas mineralizadas dos dentes ${ }^{242}$. Esse processo erosivo dos dentes é conhecido como perimolise ${ }^{10,17,218}$. Eccles e Jenkins ${ }^{57}$, 1974, relataram que é alta a incidência de hiperestesia em dentes erosionados.

Outra teoria baseia-se no desgaste abrasivo induzido pela escovação dos dentes, onde a primeira preocupação está no tamanho e na dureza das partículas abrasivas do dentifrício, na pressão de escovação exercida, na qualidade da escova dental e na 
freqüência de escovação ${ }^{21,99,216}$. Essas lesões aparecem com maior freqüência nos dentes anteriores superiores e nas áreas de pré-molares ${ }^{228}$. A aparência clínica das lesões por abrasão apresenta variações, porém, nas lesões mais desenvolvidas a configuração mais comumente encontrada assemelha-se a uma cunha ${ }^{11,226}$, sendo a superfície dentinária altamente polida, lisa e dura, além da aparência gengival saudável e Ła higiene. Nas lesões iniciais, percebe-se apenas exposição radicular ${ }^{225}$. Muitos pesquisadores têm relacionado a melhor escovação e, portanto, a menor quantidade de placa dental, com um maior grau de hiperestesia ${ }^{54,77,78}$. Associado aos cuidados de higienização, considerados a principal causa da exposição radicular e hiperestesia dentinária, vários autores têm apontado o tratamento periodontal, seja cirúrgico ou mecânico, como fator promotor de abrasão e, por conseguinte, viabilizando a hiperestesia dentinária ${ }^{6,60,126}$. A ocorrência de hiperestesia em presença das lesões por abrasão é quatro vezes maior do que a registrada frente a lesões por erosão ${ }^{228}$.

A teoria que define a abfração, sugere uma possível influência etiológica do traumatismo oclusal sobre os elementos dentários durante a função mastigatória ${ }^{119}$. Segundo essa teoria, forças excêntricas sobre os dentes podem resultar em tensões de tração, ou seja, há uma deflexão da estrutura dental que produz a ruptura dos cristais do esmalte na altura da região cervical dos elementos dentários ${ }^{22,119,276}$ tornando a região mais susceptível ao efeito solubilizador dos ácidos e abrasivo da escovação. Dentre as forças excêntricas de compressão, tração e cisalhamento sofridas pelos dentes em condições de oclusão não balanceada, os esforços de tração são os mais significantes do ponto de vista da possível formação de lesões cervicais ${ }^{119,203}$. Com base nos princípios da alavanca, os esforços de tração sobre os dentes proporcionam uma tensão resultante na altura da região cervical dos elementos dentários ${ }^{119}$. Caracteristicamente, as lesões decorrentes desses esforços excêntricos, apresentam-se geralmente isoladas acometendo um único dente e localizadas assimetricamente com relação à face vestibular dos dentes ${ }^{22}$, profundas e com 
margens bem definidas, assumindo um aspecto de cunha ${ }^{119}$. Muitos estudos relacionam as lesões dentárias cervicais não cariosas com algum tipo de trauma oclusal, apontando a concentração de esforços sobre os dentes como um processo desencadeador do aparecimento dessas lesões, coadjuvado por outras causas de natureza exógena e endógena $9,21,34,67,82,83,119,120,123,203,241,259$.

O quadro, apresentado por Pereira ${ }^{203}$, em 1995, relaciona as causas exógenas e endógenas das lesões dentárias cervicais não cariosas:

\begin{tabular}{lc}
\hline \multicolumn{2}{c}{ Lesões dentárias cervicais não cariosas } \\
Causas Exógenas & Causas Endógenas \\
\hline - Técnica de escovação incorreta & - Defeitos na junção cemento/esmalte \\
- Hábitos alimentares & - Defeitos na formação dentária \\
- Hábitos sociais & - Doenças periodontais \\
- Trauma oclusal & - Doenças sistêmicas: \\
- Procedimentos clínicos: & Bulimia \\
Tratamentos ortodônticos & Anorexia Nervosa \\
Retração gengival excessiva & Hipertireoidismo \\
Cirurgias periodontais & Distúrbios gástricos \\
Desgaste das estruturas &
\end{tabular}

\subsection{Diagnóstico da hiperestesia dentinária}

O tratamento de qualquer doença está centrado no seu correto diagnóstico. A hiperestesia dentinária, apesar de não ser considerada uma doença, apresenta sintomas que podem confundi-la com eventos patológicos que acometem os elementos dentários. O seu reconhecimento depende, portanto, da anamnese do paciente, de criteriosa análise dos sintomas e de exames clínico e radiográfico minuciosos ${ }^{203}$.

De modo geral, a história do paciente relativa à hiperestesia dentinária, quanto aos estímulos desencadeantes, a duração, freqüência e localização da dor, coincide com os seguintes aspectos ${ }^{203}$ :

- dor provocada por estímulos térmicos (alimentos frios e/ou quentes, ar durante a conversação ou mesmo aspiração), químicos (alimentos doces e ácidos) e táteis (escovação e sondagem);

- dor localizada, com grande definição do elemento dentário e da região envolvida do dente; 
- dor aguda, de curta duração e que desaparece com a remoção do estímulo;

- períodos de remissão espontânea;

- muitas vezes coincidente com estado de ansiedade do paciente.

O exame clínico prende-se à inspeção dos dentes e ao registro das particularidades dos elementos dentários que são o motivo da queixa. Há inúmeras situações clínicas que podem provocar a hiperestesia dentária. Alguns autores ${ }^{14,55,265}$, apontam algumas condições, cujos sintomas podem ser facilmente confundidos com a hiperestesia dentinária, como: trincas da coroa dentária, perda de estrutura dentária por fratura, restaurações fraturadas, cárie, sensibilidade pós-restauração, dentes em hiperfunção.

A análise dessas condições clínicas mostra que o sintoma comum entre elas é a ocorrência de dor provocada pelos mesmos agentes que estimulam a hiperestesia dentinária. Pode-se dizer que o sintoma é semelhante, os agentes desencadeadores da dor são os mesmos e a estrutura a partir de qual os estímulos são propagados também é a mesma. Com exceção da dor provocada pela hiperfunção, todos os eventos mencionados estão relacionados com algum grau de exposição dentinária, mas apresentam etiologias diferentes e variam em freqüência e severidade. É recomendável, também, que se determine a diferença entre hiperestesia e a condição patológica da polpa. Vale acrescentar que muitos indivíduos apresentam dentina exposta sem, necessariamente, apresentarem sintomatologia dolorosa ${ }^{203}$.

O quadro apresenta as características que podem definir clinicamente hiperestesia dentinária ${ }^{48,203}$.

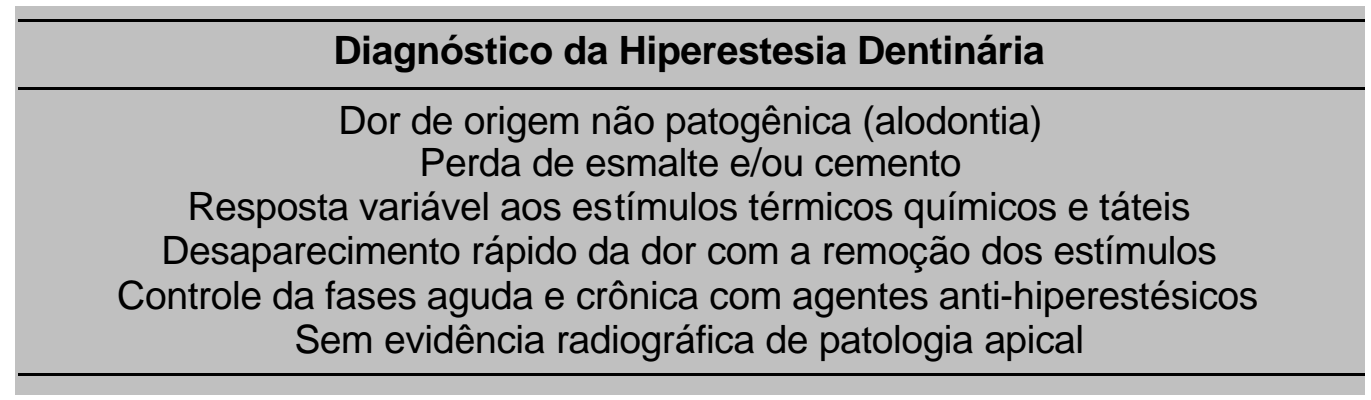


Pode-se considerar, então, que na ausência de outra patologia dental, quando os sintomas são provenientes da dentina exposta ao meio bucal ${ }^{55}$, o termo hiperestesia dentinária é utilizado para determinar tal condição ${ }^{203}$.

\subsection{Morfologia, permeabilidade e hiperestesia dentinária}

Nos estágios iniciais da dentinogênese, no local da futura junção amelodentinária, são formados os túbulos dentinários pela deposição e mineralização da pré-dentina ao redor dos processos odontoblásticos que são estruturas altamente ramificadas ${ }^{261}$. A principal característica morfológica da dentina é sua estrutura tubular preenchida por fluido, conectando a polpa à junção amelodentinária ${ }^{160}$, sendo a permeabilidade dentinária, uma conseqüência direta da presença dos túbulos dentinários.

A dentina apresenta, em média, de 30.000 túbulos por $\mathrm{mm}^{2}$, ocupando um espaço de $10 \%$ de seu volume total, que varia de $4 \%$, na junção amelodentinária, a $28 \%$, na polpa, fazendo-a uma estrutura bastante porosa. A ocorrência desses túbulos dentinários, varia tanto em número quanto em volume, na dependência da sua maior ou menor proximidade com a polpa, sendo que de 45.000 a 65.000 túbulos por $\mathrm{mm}^{2}$ são observados na região próxima à polpa, de 29.500 a 35.000 por $\mathrm{mm}^{2}$ na região mediana e 15.000 a 20.000 próximo ao limite amelodentinário, com diâmetros de cerca de $2,5 \mu \mathrm{m}, 1,2 \mu \mathrm{m}$ e $0,98 \mu \mathrm{m}$, respectivamente. Assim, espera-se que a dentina profunda seja mais permeável do que a superficial pois, como tem sido demostrado, nas proximidades do tecido pulpar concentra-se maior número de canalículos dentinários que, coincidentemente, apresentam, também, maior diâmetro e, portanto, maior volume de fluido ${ }^{27,53,66,203,260}$.

A composição química da dentina em relação ao seu volume total é aproximadamente $50 \%$ mineral, $20 \%$ água e $30 \%$ matriz orgânica, sujeita a variações em função da proximidade com a polpa. A composição mineral média é relativamente constante, pois, de acordo com a proximidade da câmara pulpar, a quantidade de dentina 
peritubular hipermineralizada, rica em cálcio, fósforo e magnésio, diminui aproximadamente na mesma proporção que a dentina intertubular, com altas concentrações de flúor e potássio e rica em colágeno, aumenta, deixando o conteúdo mineral médio similar nas dentinas superficial e profunda ${ }^{86}$. O conteúdo de água é menor na dentina superficial e maior na profunda, pois uma significante fração do conteúdo total de água da dentina está confinada nos túbulos dentinários. E ainda, a dentina profunda possui mais colágeno intratubular do que a superficial, não resultante de estímulos externos. Essas características contribuem para a heterogeneidade da dentina ${ }^{66,152,160,260}$.

As paredes dos túbulos e suas ramificações são revestidas pela dentina peritubular, mais mineralizada do que a dentina intertubular, e com menos matriz orgânica. A dentina peritubular, em geral, atinge sua máxima espessura nas porções média e superficial, sendo que, com o passar do tempo, observa-se uma significante correlação entre o estreitamento progressivo dos túbulos e a deposição de dentina peritubular, que pode, ainda, ser acelerada por fatores externos ${ }^{243,252}$. O mais interessante é que mesmo nos níveis mais densos da dentina esclerótica, menos de $50 \%$ dos túbulos estão obliterados ${ }^{98}$.

Os processos odontoblásticos e seu conteúdo líquido permeiam a estrutura dentinária e são os responsáveis por seu metabolismo. Existe uma considerável controvérsia sobre o quanto os processos odontoblásticos se estendem perifericamente dentro dos túbulos. Relatos de muitas autoridades ${ }^{27,261,262,266}$ sugerem que os processos odontoblásticos apenas se estendem a aproximadamente $20 \%$ a $25 \%$ do comprimento dos túbulos, correspondendo um terço da distância da polpa à junção amelodentinária, isto é, que os dois terços periféricos dos túbulos são desprovidos de processos odontoblásticos. Segundo relatado por Thomas $^{261}$, em 1985, as estruturas visualizadas nos túbulos, na região mais superficial e média da dentina, são estruturas eletrodensas de natureza extracelular que circundam o lúmen tubular, distinguíveis dos processos odontoblásticos quando as duas estruturas são vistas juntas na dentina profunda. As sim, essa estrutura 
corresponde a uma camada interna hipomineralizada de dentina peritubular chamada lâmina limitante, separada da dentina intertubular pelo espaço da matriz dentinária peritubular. Também Yoshiyama e colaboradores ${ }^{280,284}$ relataram sobre a presença dessa estrutura no interior dos túbulos, podendo influenciar a permeabilidade dentinária.

O metabolismo da dentina, quando exposta, caracteriza-se pela deposição gradativa de componentes minerais e orgânicos do fluido pulpodentinário ao longo das paredes internas dos túbulos, aumentando a espessura da dentina peritubular e reduzindo a permeabilidade dentinária ${ }^{138,139}$. O fluido intersticial da câmara pulpar está sob uma pequena mas significativa pressão positiva que provoca uma filtração lenta do fluido a partir da polpa, através dos túbulos para a superfície da dentina exposta. O fluido dentinário não apresenta grânulos ou células e possui uma composição típica de fluido extracelular. Apresenta alta concentração de íons sódio, baixa quantidade de íons potássio, proteínas plasmáticas, e, provavelmente, é saturado em íons cálcio e fosfato. Espera-se que reações físico-químicas espontâneas, mais do que uma atividade celular, ocorram quando há uma exposição de túbulos dentinários, de tal forma que, após alguns dias ou semanas, sais de fosfato de cálcio se depositem dentro dos túbulos dentinários, formando dentina peritubular e diminuindo o diâmetro do túbulo ou, então, precipitando intratubularmente uma variedade de sais de fosfato de cálcio como cristais, que também dificultam o movimento do fluido, transformando a dentina tanto menos permeável quanto sensitiva ${ }^{43}$.

A presença dessa mineralização intratubular distinta da dentina peritubular é um fator significante na obstrução dos túbulos dentinários que ocorre predominantemente em resposta a estímulos externos e, indubitavelmente, tem efeito na redução da permeabilidade dentinária ${ }^{243,260}$. Reações similares, porém mais lentas, ocorrem na dentina coberta por esmalte ou cemento, mas, ao invés de meses, a reação requer décadas. Então, o processo de esclerosamento da dentina, pode ocorrer fisiologicamente e, portanto, se acentua com o 
passar do tempo, ou reacionalmente com a resposta rápida a qualquer processo destrutivo da superfície dentária ${ }^{243}$.

Os depósitos intratubulares restringem o movimento hidráulico do fluido através da dentina, pois provocam a diminuição do diâmetro funcional dos túbulos mais do que o anatômico $^{135}$. Microscopicamente, o comprimento dos túbulos é 2000 a 3000 vezes maior que o seu diâmetro, porém, as projeções cristalinas ou fibras colágenas que se estendem ao longo dos túbulos reduzindo o movimento dos fluidos não são detectadas por essa técnica. Segundo Michelich et al. ${ }^{135}$, em 1978, o diâmetro funcional dos túbulos utilizando as técnicas hidrodinâmicas é apenas $5 \%$ a $10 \%$ do anatômico, ou seja, o diâmetro funcional dos túbulos é menor que $0,1 \mu \mathrm{m}$, enquanto que o anatômico é aproximadamente $1 \mu \mathrm{m}$.

Conforme os escritos de Maroli, Khera e Krell ${ }^{130}$, em 1992, a permeabilidade dentinária gradualmente aumenta oclusocervicalmente, sendo o terço oclusal o menos permeável e, o cervical, o de maior permeabilidade, pois está mais próximo da polpa do que o oclusal. Richardson, Tao e Pashley ${ }^{220}$, em 1991, concluíram que a permeabilidade de preparos para coroas totais é mais alta na superfície mesial, seguida pela vestibular, distal, oclusal e superfícies linguais. Microscopicamente, o terço cervical mostrou maior quantidade de túbulos abertos. Pashley et al. ${ }^{161}$, em 1987, estudando a variabilidade regional da dentina, verificaram que a permeabilidade da dentina coronária oclusal não é uniforme, sendo maior nas áreas acima dos cornos pulpares e menor no centro da superfície oclusal. Estudos em microscopia eletrônica de varredura de áreas permeáveis e não permeáveis revelaram a presença de túbulos abertos em ambas as regiões. Presumivelmente, tem mais material intratubular na dentina da região central do que nos túbulos localizados sobre os cornos pulpares, o que pode justificar o fato de se encontrar regiões não permeáveis com túbulos abertos e condutividade hidráulica zero, isto é, apesar dos túbulos parecerem permeáveis, não são ${ }^{160}$. Essa observação indica a importância da combinação de técnicas 
de microscopia eletrônica de varredura com técnicas funcionais, pois qualquer uma delas isoladamente pode levar a interpretações enganosas ${ }^{71,124}$

Se o mecanismo de transmissão dos estímulos através da dentina for por intermédio da movimentação de fluidos, a hiperestesia dentinária está diretamente relacionada à dimensão, número e grau de obstrução dos túbulos. Brännström e colaboradores ${ }^{25,26,30,32}$ e também Ishikawa ${ }^{103}$, em 1996, demonstraram a desobstrução dos túbulos na dentina hiperestésica. Estudos de Yoshiyama et al. $^{282}$, em 1989, e de Yoshiyama et al. ${ }^{283}$, em 1990, empregando microscopia eletrônica de varredura e de transmissão, em biópsias de dentina extraídas de áreas hiperestésicas mostram que, nessas regiões, a maioria dos túbulos encontra-se aberta, enquanto nas áreas naturalmente não hiperestésicas os túbulos estão dbliterados com cristais minerais de diferentes dimensões. E, ainda, que os túbulos nos locais hiperestésicos eram duas vezes mais largos do que nos locais não hiperestésicos. Absi, Addy e Adams², em 1989, utilizando-se de réplicas confirmaram estes achados clinicamente. Observações dessa natureza reforçam a relação da hiperestesia com condutividade hidráulica da dentina e antecipam o raciocínio de que o tratamento da dentina hiperestésica depende, em princípio, da obliteração dos túbulos dentinários.

Ainda analisando a dentina cervical hiperestésica e não hiperestésica, Absi, Addy e Adams $^{1}$, em 1987, observaram que existe um aumento significativo do número de túbulos por área, aproximadamente de oito vezes nos dentes hiperestésicos, além de apresentaremse significativamente mais amplos. Rimondini, Baroni e Carasi ${ }^{221}$, em 1995, concordam que os túbulos dentinários da dentina hiperestésica parecem ser mais numerosos e amplos. Essas características dão suporte à teoria da permeabilidade hidrodinâmica da dentina hiperestésica. Ciucchi et al. ${ }^{41}$, em 1994, observaram microscopicamente a relação positiva entre hiperestesia e túbulos abertos na superfície cervical exposta, coincidindo com estudos in vivo e com a hipótese hidrodinâmica de indução da dor através de túbulos desobstruídos. 
Porém, túbulos abertos também foram observados em dentes não hiperestésicos, possivelmente por estarem ocluídos na subsuperfície intratubular.

A maioria dos estudos examinou a desobstrução dos túbulos dentinários na superfície do dente sem, porém, garantir que essa desobstrução se estenda ao longo do túbulo até a polpa. Absi, Addy e Adams ${ }^{1}$, em 1987, além de pesquisar a desobstrução superficial dos túbulos, também observaram que enquanto muitos túbulos estavam completamente desobstruídos, alguns estavam ocluindo apenas parte da espessura da dentina. Segundo Holland ${ }^{98}$, em 1994, há três maneiras de um túbulo estar ocluído: na superfície, pela smear layer, placa, mineralização ou agentes oclusores; na periferia, pela deposição da dentina peritubular; e mais pulparmente, pela deposição de dentina terciária ou reparadora. Pashley et al. ${ }^{174}$, em 1978, mostraram claramente que o grau de oclusão tubular está relacionado com a permeabilidade.

Seqüencialmente aos outros estudos, Yoshiyama et al. ${ }^{281}$, em 1996, observando o lúmen dos túbulos dentinários de dentina radicular hiperestésica, identificaram, em $75 \%$ dos casos, a presenças das estruturas chamadas tubulares ou lâminas limitantes. Na dentina não hiperestésica, notaram somente $20 \%$ dos túbulos com essas estruturas. Os autores especularam a possibilidade dessas estruturas serem as responsáveis pela manutenção dos túbulos dentinários abertos, tendo, portanto, papel muito importante na produção da hiperestesia. Sugeriram, ainda, a possibilidade dessas estruturas impedirem o desenvolvimento espontâneo do processo físico-químico de oclusão dos túbulos dentinários pela precipitação fisiológica de cristais minerais, como pode ocorrer nos casos de dentina exposta não hiperestésica. Essa poderia ser a explicação para a persistência da hiperestesia mesmo após o efetivo bloqueio dos túbulos dentinários.

As características da permeabilidade dentinária radicular foram examinadas por Fogel, Marshall e Pashley ${ }^{62}$, em 1988 e também por Fogel e Pashley ${ }^{61}$, em 1993. A dentina radicular é coberta por uma fina camada de cemento de 25 a $50 \mu \mathrm{m}$, que mesmo 
após removido, a dentina permanece com relativa impermeabilidade. Apenas após a remoção de 0,3 a $0,5 \mathrm{~mm}$ da dentina radicular, a permeabilidade começa a aumentar, porém, mesmo a dentina radicular interna mais permeável tem apenas $20 \%$ da permeabilidade da dentina coronária. Exames da dentina radicular periférica revelaram que os túbulos têm menor diâmetro do que na dentina coronária e nem sempre se estendem até o cemento. Se a dentina radicular fosse tão permeável quanto à coronária, sua manipulação pelos periodontistas e higienistas não seria possível sem anestesia. Então, há consideráveis evidências da grande variação da permeabilidade dentinária de uma região para outra do dente.

Assim como as variações da desobstrução tubular, tanto a densidade como o tamanho dos túbulos dentinários e também, por conseqüência, a hiperestesia variam em diferentes níveis longitudinais no dente e em diferentes profundidades na dentina ${ }^{66}$. Em que extensão as dimensões e o número de túbulos afetam a hiperestesia e a permeabilidade não se sabe exatamente, uma vez que podem ser também influenciadas por diferentes fatores, incluindo o grau de inervação e a espessura dentinária ${ }^{62}$.

\subsection{Mecanismos da hiperestesia dentinária}

Alguns aspectos relacionados com a hiperestesia dentinária, centrados na grande diversidade de respostas sensoriais, permanecem sem explicação definitiva, dificultando o plano de tratamento e comprometendo os resultados clínicos ${ }^{203}$. Alguns desses aspectos são:

- nem todas as lesões dentárias cervicais não cariosas apresentam hiperestesia dentinária, apenas cerca de $57 \%$ dessas lesões apresentam-se hiperestésicas ${ }^{9}$;

- o grau de hiperestesia varia de paciente para paciente, de dente para dente no mesmo paciente e até em áreas diferentes de dentina exposta no mesmo dente ${ }^{203,206}$;

- a ocorrência de dentina hiperestésica varia entre os grupos dentários, sendo mais freqüente nos pré-molares, com cerca de $68 \%$ dos casos ${ }^{9}$; 
- a resposta hiperestésica varia conforme o estímulo aplicado, sendo extremamente alta quando do contato com substâncias que produzem elevada pressão osmótica como as frutas cítricas e os doces, e pressão física com os jatos de $a r^{205}$;

- a dor é recorrente e pode desaparecer temporariamente sem qualquer tratamento ${ }^{203}$;

- a hiperestesia pode desaparecer com a aplicação de placebos ${ }^{80,122,205,206}$;

- não tem relação com a idade do paciente, podendo acometer jovens e adultos em proporções semelhantes ${ }^{9}$.

Várias hipóteses tem sido sugeridas para explicar o mecanismo da hiperestesia dentinária, embora nenhuma delas leve a um perfeito entendimento de como os estímulos aplicados na superfície de uma dentina hiperestésica possam ser transmitidos para a polpa e provocar dor $54,115,164,175,184,203$.

Apesar da hiperestesia dentinária não ser um fenômeno recente e nem raro, sua etiologia é pobremente entendida. As evidências favorecem a Teoria Hidrodinâmica, geralmente creditada a Brännström, como sendo a mais aceita para explicar a hiperestesia dentinária $26,32,175,222,269$. A despeito do movimento dos fluidos no interior dos túbulos dentinários ter sido, originariamente proposto por autores como Neil, Kramer e Gysi no final do século dezenove, Brännström, em 1963, procurando uma justificativa para a dentina periférica, desprovida de fibras nervosas, ser tão sensível, reintroduziu a Teoria Hidrodinâmica levando-a a aceitação pela comunidade científica ${ }^{72,222}$. Segundo essa teoria, suportada por numerosos experimentos de Brännström e seus colaboradores ${ }^{25,31,66,107}$, tanto in vitro como in vivo, alguns estímulos provocam o rápido deslocamento dos fluidos, na ordem de 2 a $4 \mathrm{~mm} /$ segundo $^{115}$, em qualquer direção através dos túbulos, ativando os mecanorreceptores das fibras nervosas pulpares, gerando a transmissão ao sistema nervoso central de um impulso que é instantaneamente percebido como dor. Essa teoria auxiliou a explicar como uma grande variedade de estímulos de diferente natureza, principalmente mecânicos, térmicos, osmóticos e hidrostáticos, aparentemente não relacionados, podem todos causar dor ${ }^{160}$. 
As estruturas de proteção, esmalte e cemento, desempenham uma importante função no mecanismo da hiperestesia dentinária, protegendo a dentina da exposição ao meio bucal e impedindo a movimentação do fluido no interior dos túbulos dentinários em direção a polpa ou em sentido contrário, na dependência da natureza do estímulo. A movimentação do fluido provoca uma variação de pressão intrapulpar positiva ou negativa e conseqüente estimulação das terminações nervosas próximas da camada odontoblástica ${ }^{164}$. Brännström e Aström ${ }^{26}$, em 1972, afirmaram que o movimento do fluido dentinário para o exterior dos túbulos é mais responsável pelo aparecimento da dor do que o deslocamento em direção à polpa.

Se o movimento do fluido através dos túbulos dentinários for, de fato, o estímulo que antecede a produção dor dentinária, então é importante examinar os fatores físicos que regulam este movimento. Então, ao se relacionar a hiperestesia dentinária com a movimentação de fluido, podem-se estabelecer algumas variáveis que regulam a condutividade hidráulica da dentina e que, portanto, podem modificar o seu padrão hiperestésico ${ }^{175}$. As variáveis são formalizadas pela Lei de Poiseuille-Hagen na equação que inclui o comprimento dos túbulos dentinários, pressão mecânica, física ou química aplicada, viscosidade do fluido dentinário, e o raio dos túbulos elevado à quarta potência, considerado mais importante na movimentação do fluido do que o comprimento do túbulo, isto é, a espessura da dentina ${ }^{160}$. As mudanças de temperatura da dentina têm dois importantes efeitos no movimento de fluido através dos túbulos dentinários. Um, a viscosidade, que varia inversamente com a temperatura e outro, quando a dentina é aquecida, os túbulos se tornam levemente mais largos devido ao aumento do coeficiente de expansão linear. Apesar do aumento das dimensões tubulares ser pequeno, na equação da lei, o raio é elevado à quarta potência, permitindo que pequenas mudanças produzam efeitos significantes. Reduzindo o raio funcional dos túbulos pela oclusão parcial das embocaduras deve reduzir grandemente o fluxo de fluido e a hiperestesia dentinária ${ }^{135,274}$. 
A resistência do movimento do fluido através da dentina foi também analisada experimentalmente por Pashley, Livingston e Greenhill ${ }^{186}$, em 1978, em dentes recémextraídos, antes e após a criação da smear layer e antes e após a remoção do tecido pulpar. A resistência total foi calculada como a soma de três resistências arranjadas em série. A resistência da superfície, devido à presença da smear layer, foi responsável por $86 \%$ da resistência total do movimento do fluido através da dentina. A resistência oferecida pelo tecido pulpar foi de apenas $7 \%$, enquanto que a resistência intratubular foi responsável por $6 \%$ do total. Em outra série de experimentos também realizados, em 1978, Reeder et al. ${ }^{217}$, avaliaram a espessura dentinária. Estes experimentos claramente demostraram a importância do raio dos túbulos, comprovando que pequenas mudanças nos raios tubulares têm maior efeito no deslocamento do fluido através da dentina do que grandes mudanças de espessura $^{107}$.

Pereira $^{203}$, em 1995, salientou que o efeito de um determinado estímulo aplicado na superfície dentinária exposta, sobre a movimentação do fluido pulpodentinário, mantém relação inversa com a espessura da camada de dentina remanescente e com a viscosidade do fluido e relação direta com o número de túbulos expostos e seu raio. Como base de raciocínio clínico, espera-se que uma exposição dentinária profunda em um paciente jovem esteja mais sujeita à hiperestesia do que em um paciente de idade avançada sob o mesmo estímulo e com exposição de igual profundidade, esperam-se modificações no padrão de esclerosamento dentinário e da própria fisiologia da polpa.

Pode-se antecipar, então, segundo Pashley ${ }^{164}$, em 1986, e com base no princípio da hidrodinâmica, que qualquer diminuição no movimento do fluido dentinário ou mesmo na permeabilidade dentinária, fatalmente haverá uma correspondente redução da hiperestesia. Deste modo, o objetivo do tratamento da hiperestesia dentinária deve ser a restauração da impermeabilidade original dos túbulos (Figura 1). 


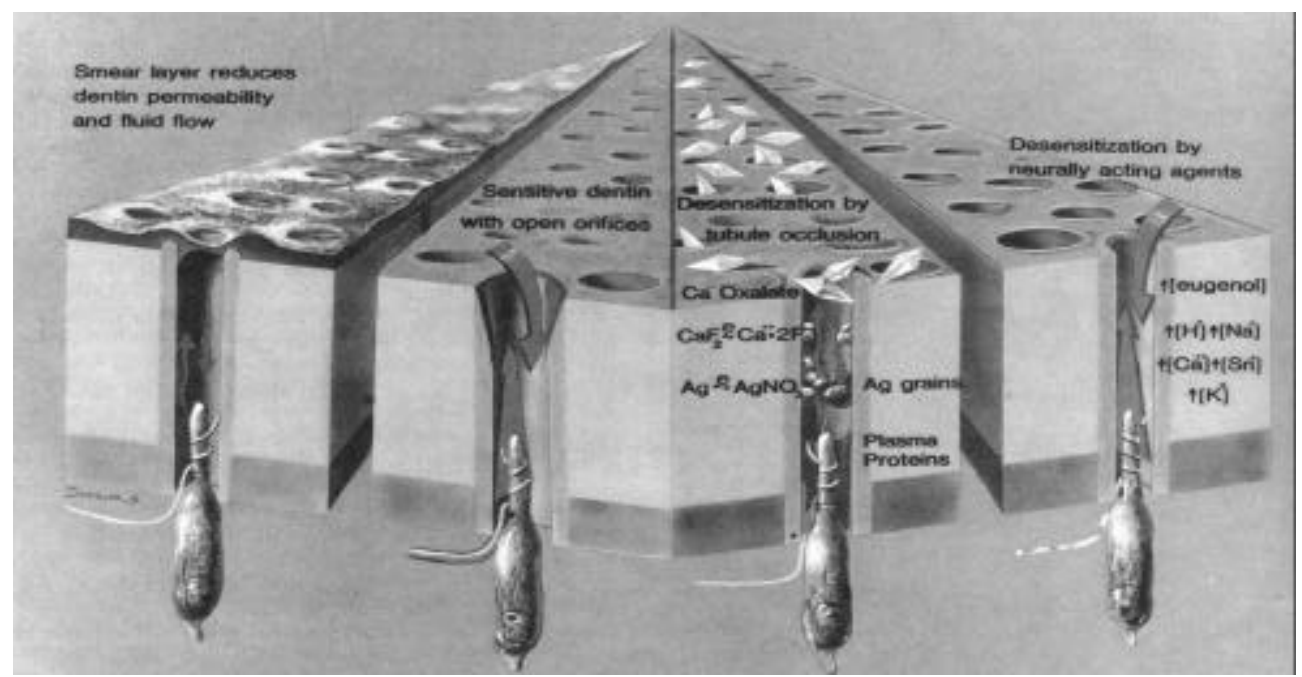

Figura 1 - Resumo dos mecanismos anti-hiperestésicos. Os túbulos dentinários abertos (à esquerda) permitem que forças hidrodinâmicas estimulem mecanoreceptores causando dor. A dessensibilização pela oclusão tubular (direita) pode restringir o movimento do fluido, diminuindo a dor. A criação da smear layer é efetiva como uma camada equivalente de precipitados cristalinos (esquerda). A dessensibilização pelo bloqueio da atividade nervosa (direita), não interfere com o movimento do fluido, mas reduz a resposta nervosa. Os sais de potássio são exemplos desse tipo de dessensibilização ${ }^{164}$.

\subsection{Tratamento da hiperestesia dentinária - histórico}

Muitas terapias foram propostas no passado para aliviar a dor dentinária, porém as investigações científicas e primeiras publicações sobre a hiperestesia dentinária ocorreram aproximadamente por volta de $1860^{222}$. O emprego do ópio, iniciado em 400 a.C. no tratamento da hiperestesia dentinária, foi defendido até meados de 1000 d.C. Depois, passou-se a recomendar uma grande variedade de tratamentos baseados na aplicação de plantas e insetos sobre áreas sensíveis. Isso, até o princípio do século XIX. A cocaína foi introduzida em 1859 e outros medicamentos como o creosoto, o ácido tânico e o arsênico foram utilizados até o final do século passado. Nos anos 1920, as soluções aquosas de nitrato de prata com iodo apresentaram-se efetivas no alívio da dor dentinária. Mais tarde, surgiu o iodeto de prata, apontado como eficaz no alívio da hiperestesia dentinária e, por não escurecer a superfície dental, mais vantajoso que o nitrato de prata. Houve, ainda, uma teoria nutricional da hiperestesia, que sugeria o emprego de vitaminas $A$ e D liposolúveis ${ }^{116,222}$. 
Em 1935, Grossman ${ }^{84}$ estabeleceu o tipo de terapia a ser empregado em cada situação. Por se mostrar mais eficiente, o nitrato de prata seria o mais indicado para região cervical dos dentes posteriores e para as superfícies linguais dos anteriores. Por não manchar, a formalina deveria ser usada nas faces vestibulares dos dentes anteriores. Ao carbonato de sódio potássio caberiam as áreas próximas à polpa. Nos anos 50 , eram utilizados óleo de oliva quente, formaldeído, nitrato de prata, cloreto de zinco, carbonato de cálcio e fluoreto de sódio. Muitos desses materiais eram agentes de ação entorpecente, alguns estimulavam a formação de dentina secundária, e outros eram adesivos e cobriam as áreas hiperestésicas ${ }^{116,222}$.

Acredita-se que a maior parte dos medicamentos que reduz a hiperestesia dentinária, o faz tanto por cristalização no interior como na embocadura dos túbulos dentinários, mas de qualquer forma, diminuindo a movimentação do fluido. Os compostos mais largamente estudados com os respectivos autores das primeiras publicações no tratamento da dentina hiperestésica estão relacionados no quadro a seguir ${ }^{116,222}$ :

\begin{tabular}{|c|c|}
\hline Agentes anti-hiperestésicos & Autores das primeiras publicações \\
\hline formalina & Groosman, 1935 \\
\hline formaldeído & Franken, 1931; Forrest , 1963 \\
\hline glicerina & Colaneri, 1952 \\
\hline cloreto de estrôncio & Pawlowska, 1956; Cohen, 1961; Meffert e Hoskins, 1964 \\
\hline citrato de sódio & Zinner, Duanny e Lutz, 1977 \\
\hline nitrato de prata & Colaneri, 1952; Everett, 1964 \\
\hline nitrato de potássio & Hodosh, 1974; Green, Green e McFall, 1977 \\
\hline fosfato dicálcio & Hiatt e Johansen, 1972 \\
\hline hidróxido de cálcio & Ljarkjend, Tronstad, 1972; Levin et al.,1973 \\
\hline monofluorfosfato de sódio & Bolden et al. e Hazen et al.,1968 \\
\hline fluoreto de sódio & Lukomsky, 1941; Hoyt e Bibby, 1943; Clement, 1947 \\
\hline fluoreto estanhoso & Miller et al., 1969; Zinner et al.,1977 \\
\hline iontoforese & Siemon , 1960 e Gangarosa et al., 1978 \\
\hline oxalato de potássio & Pashley et al., 1984 \\
\hline ionômero de vidro & Charbeneau e Bozel, 1979 \\
\hline resinas e adesivos & Dayton et al., 1974 e Brännström et al..,1979 \\
\hline luz laser & Goodis e White, 1989 \\
\hline
\end{tabular}




\subsection{Mecanismos de ação das terapias e agentes anti-hiperestésicos}

Como a teoria mais aceita para explicar o mecanismo da hiperestesia dentinária é a Hidrodinâmica, os agentes mais utilizados são os que interagem com a condutividade hidráulica da dentina. Assim, o objetivo do tratamento da hiperestesia dentinária é promover a obliteração dos túbulos dentinários ${ }^{203}$.

São inúmeros os agentes e as terapias preconizados para o tratamento da hiperestesia dentinária, o que denota, em princípio, que nenhum deles é completamente eficaz para tal finalidade ${ }^{203}$. De acordo com Grossman ${ }^{84}$, em 1935, algumas características devem ser consideradas no momento de se escolher um agente anti-hiperestésico dentinário, entre elas: promover efeito imediato e duradouro, ser de fácil aplicação, não ser irritante à polpa, ser bem tolerado pelo paciente, não deve manchar o dente e ser de baixo custo.

Uma vez que a hiperestesia dentinária é um fenômeno sensorial complexo, depende de fatores fisiológicos e emocionais não completamente definidos, não se dispõe até o momento de um produto que preencha todos os requisitos mencionados acima. Ainda porque a hiperestesia é um sintoma decorrente, em princípio, de um processo destrutivo das estruturas dentárias mineralizadas, tratá-la sem estabelecer e controlar suas causas primárias e sem a devida orientação do paciente, seria uma tarefa mal sucedida a curto prazo. Efeito imediato e duradouro dificilmente será alcançado por qualquer agente ou terapia anti-hiperestésica para todas as circunstâncias clínicas que envolvem este processo. Por outro lado, terapias de fácil aplicação se alternam com os procedimentos clinicamente mais complexos e dispendiosos para o paciente, com resultados igualmente imprevisíveis ${ }^{203}$.

Outro requisito importante está relacionado com o conforto do paciente durante o tratamento. A absoluta maioria das terapias anti-hiperestésicas exige a remoção de depósitos moles ou duros da superfície dentinária a ser tratada. As manobras profiláticas 
disponíveis, como as raspagens e polimentos corono-radiculares provocam grande desconforto, exigindo muitas vezes a aplicação de anestesia antes do tratamento. Um paciente com hiperestesia generalizada, envolvendo vários dentes com lesões cervicais não cariosas, será vítima de grande desconforto caso não seja selecionada a conduta clinica mais apropriada para o seu tratamento, Nessas condições e com a eventual necessidade de isolamento absoluto para levar a cabo métodos anti-hiperestésicos mais sofisticados procedimentos restauradores, por exemplo - perde-se o requisito da simplicidade do tratamento ${ }^{203}$.

Os agentes ou terapias anti-hiperestésicas podem ser classificadas de acordo com seu suposto modo de ação, em :

\subsubsection{Agentes de ação antiinflamatória}

A literatura pertinente ao assunto menciona, com freqüência, as drogas antiinflamatórias como agentes anti-hiperestésicos ${ }^{19,139,265}$. É preciso compreender, entretanto, que a ação de uma droga anti-inflamatória, como o são os corticoesteróides, implica, em princípio, em que a hiperestesia dentinária esteja relacionada com inflamação pulpar como ocorre, por exemplo, nos dias que sucedem a um preparo cavitário ${ }^{203}$. Segundo Krauser ${ }^{116}$, em 1986, muitos acreditam que sua ação tópica sobre a dentina exposta de um preparo cavitário é capaz de diminuir a sensibilidade pós-operatória. Também Bowers e Elliot ${ }^{19}$, em 1964, após aplicar corticosteróide e eliminar traumas oclusais de dentes hiperestésicos, concluíram que o trauma oclusal provoca o aumento da pressão intrapulpar e, logo, o processo inflamatório e a dor.

Os corticosteróides atuam sobre o tecido inflamado reduzindo a pressão tecidual e, com ela, a estimulação das terminações nervosas que causam a dor. Alguns estudos têm constatado ação efetiva da prednisolona a $1 \%$ em combinação com para-cloro-fenol, m- 
cresil acetato e cânfora em dentina cirurgicamente exposta ${ }^{118}$, e da parametasona sob restaurações de ouro ${ }^{149}$ na redução da hiperestesia.

Não são drogas de efeito imediato e o rápido alívio proporcionado quando aplicados sobre a dentina, não tem sido relacionado com a ação do hormônio propriamente dito, pois sabe-se que não reduz a inflamação pulpar histologicamente ${ }^{149,265}$. E, ainda, Mjor e Furseth $^{139}$, em 1968, demonstraram que os corticoesteróides podem provocar o aumento da mineralização da dentina peritubular, reduzindo a luz dos túbulos e o movimento do fluido. Mas, se os corticoesteróides não são drogas que agem rapidamente, como explicar sua rápida ação anti-hiperestésica quando aplicados na dentina sensível.

Não há evidências, portanto, de que os conticoesteróides tenham aplicação definida nos casos de hiperestesia dentinária típica, mas quando utilizados, são aplicados sobre a dentina com bolinhas de algodão, ou por meio da brunidura da superfície sensível com um bastão de madeira ${ }^{14}$.

\subsubsection{Despolarização das terminações nervosas}

\section{Nitrato de Potássio}

Até a descoberta das propriedades anti-hiperestésicas do nitrato de potássio divulgadas por Hodosh ${ }^{94}$, em 1974, a abordagem mais aceita pelos pesquisadores para aliviar o problema era obstruir os túbulos dentinários mecanicamente. O nitrato de potássio caracteriza-se como um agente de ação prolongada que atua pela despolarização das terminações nervosas, além de não ser irritante para os tecidos gengivais e nem descolorante da superfície dental. Também não diminui a condutividade hidráulica da dentina, nem promove a obstrução dos túbulos dentinários pela deposição de cristais, mas, ainda assim, é considerado um agente efetivo no tratamento da dentina hiperestésica ${ }^{12,93,94,258}$. 
De acordo com Kim ${ }^{113}$ e Pashley ${ }^{164}$, ambos em 1986, o nitrato de potássio atua pela despolarização das membranas das fibras nervosas devido ao aumento da concentração de potássio extracelular, bloqueando a percepção dos mecanorreceptores aos movimentos do fluido dentinário e, portanto, dificultando a passagem do estímulo doloroso. O estudo de Markowitz e $\mathrm{Kim}^{129}$, em 1985, confirmou a informação de que os íons potássio reduzem a sensibilidade neural da polpa em 85,4\%.Também Stead, Orchardson e Warren $^{244}$, em 1996, e Peacock e Orchardson ${ }^{202}$, em 1999, avaliaram o desempenho dos íons potássio nos túbulos dentinários concluindo que o aumento da concentração desses íons na extremidade interna dos túbulos dentinários pode inativar as terminações nervosas pulpares, entretanto, tem efeito passageiro pois, a concentração de potássio é diminuída pela ação do fluido dentinário.

Desde que se considera verdadeira a ação neural do nitrato de potássio, caracterizada pela difusão do potássio através dos túbulos dentinários até a polpa, não se recomenda a aplicação de agentes de ação oclusiva sobre a dentina previamente à utilização de produtos à base dessa substância. Isto porque a impermeabilização da dentina deverá impedir que o potássio alcance as terminações nervosas em nível de polpa dental $^{93,95}$. Assim, sugere-se a aplicação tópica do nitrato de potássio na forma de gel, composto por fluoreto de sódio e nitrato de potássio a 5\%, seguido do tratamento doméstico com dentifrício também à base de nitrato de potássio a $5 \%{ }^{4,95,238}$.

\subsubsection{Agentes de efeito oclusivo sobre os canalículos dentinários}

Os agentes e as terapias anti-hiperestésicas mais comumente empregados são aqueles que interagem com a condutividade hidráulica da dentina, obliterando a embocadura dos canalículos dentinários. Tem sido demostrado que a dentina hiperestésica apresenta maior número de túbulos abertos comparativamente à dentina exposta não hiperestésica ${ }^{1,282,283}$ e que o desaparecimento da hiperestesia coincide com a oclusão total 
ou parcial dos túbulos dentinários ${ }^{1}$. A obliteração dos canalículos dentinários pode ocorrer por meio da precipitação de proteínas que compõe os processos de Tomes, pela formação e deposição de cristais na embocadura e no interior dos túbulos dentinários, pelo recobrimento da dentina e/ou impregnação dos túbulos e, finalmente, através de procedimentos restauradores de modo geral ${ }^{203,243}$.

\subsubsection{Precipitação de proteínas}

Agentes químicos que destroem os prolongamentos odontoblásticos compõem um grupo de produtos muito utilizados para o controle da hiperestesia dentinária. Encontram-se entre esses agentes o cloreto de zinco, formalina, paraformaldeido, ácidos carbólicos e seus derivados, nitrato de prata e outros ${ }^{222}$, que são aplicados sobre a dentina isoladamente ou em combinação com outros ingredientes.

\section{Nitrato de prata}

O nitrato de prata coagula os prolongamentos odontoblásticos rapidamente, formando albuminato de prata, um precipitado relativamente sólido que bloqueia os túbulos, porém adquire coloração escura quando exposto à luz $z^{222,265}$. A utilização subseqüente de cloreto de sódio, reduz a pigmentação da dentina mas, ainda assim, o seu emprego é bastante limitado atualmente pois acredita-se que é potencialmente prejudicial à polpa e à gengiva $^{116}$.

Anderson e Mattews ${ }^{7}$, em 1966, julgaram o efeito anti-hiperestésico do nitrato de prata desfavorável quando aplicado em dentina exposta de preparos cavitários. E, ainda, Greenhill e Pashley ${ }^{81}$, em 1981, mostraram em seus estudos que a presença de proteínas nos túbulos dentinários tem pouco a ver com a redução da condutividade hidráulica da dentina provocada pelo nitrato de prata. 


\section{Formalina}

A utilização da formalina como agente anti-hiperestésico, atuando pela precipitação de proteínas, foi proposta inicialmente por Grossman ${ }^{84}$, em 1935. Sugeria o emprego tópico da formol a $40 \%$, especialmente para o tratamento da hiperestesia em dentes anteriores pois, ao contrário do nitrato de prata, essa substância não mancha a dentina. Entretanto, existe o risco de agressão à polpa uma vez que essa droga penetra rapidamente através dos canalículos dentinários ${ }^{203}$.

Addy e Mostafa ${ }^{4}$, em 1988, após estudarem a atuação do formaldeído na oclusão tubular in vitro, concluíram que não produz qualquer efeito. Greenhill e Pashley ${ }^{81}$, em 1981 demonstraram, também, que a aplicação da formalina a $10 \%$ exerce pouco efeito sobre a condutividade hidráulica da dentina.

\subsubsection{Deposição de partículas}

\section{Brunidura}

Alguns medicamentos indicados para o tratamento da hiperestesia dentinária são aplicados por meio da brunidura com um bastão de madeira macia. A madeira considerada conveniente para essa finalidade por sua resistência e flexibilidade, é a aranjeira ${ }^{203}$. Foi Grossman $^{84}$, em 1935, quem preconizou a brunidura com madeira de laranjeira e carbonato de sódio potássio na superfície hiperestésica.

Pashley, Leibach e Horner ${ }^{184}$, em 1987, relatam o efeito oclusivo sobre os túbulos dentinários após a brunidura com uma pasta composta por fluoreto de sódio, kaolim e glicerina comparado com o efeito da brunidura sem qualquer produto químico. Constataram que a simples brunidura com um bastão de madeira foi a terapia mais efetiva, reduzindo a permeabilidade dentinária em até $80 \%$. Pereira et al. $^{204}$, em 1990, confirmaram por meio de avaliação clínica, o desaparecimento da dor em cerca de $70 \%$ dos dentes tratados após 
quatro sessões de simples brunidura das áreas hiperestésicas com bastão de madeira. Tem-se sugerido que a brunidura da dentina produz uma smear layer característica a partir de partículas da própria madeira e de resíduos de dentina, forçados mais profundamente nos túbulos dentinários ${ }^{184}$.

A brunidura é um procedimento bastante simples e rápido, embora extremamente dolorido, limitando o seu emprego como primeira opção. A superfície da dentina exposta é friccionada com um bastão de madeira macia num tempo que pode variar de 1 a 2 minutos. Além do desconforto para o paciente, um dos inconvenientes dessa técnica é o difícil acesso às lesões muito pequenas ${ }^{203}$.

\section{Hidróxido de cálcio}

O verdadeiro mecanismo de ação do hidróxido de cálcio é desconhecido, mas acredita-se que ele possa obliterar os túbulos dentinários por intermédio da deposição de pequenos cristais, oriundos possivelmente da precipitação de sais minerais, e estimular a formação de dentina peritubular ${ }^{138}$.

A ação oclusiva do hidróxido de cálcio em $75 \%$ é demonstrada por Pashley e colaboradores $^{183}$, em 1986, tanto sobre dentina condicionada com ácido quanto sobre a smear layer. Entretanto, a aplicação subseqüente de ácido cítrico a $6 \%$, devolve a permeabilidade original à dentina, sugerindo que a ingestão de alimentos ácidos e refrigerantes pode remover o hidróxido de cálcio, caracterizando-o como um tratamento instável. Já em 1981, Greenhill e Pashley ${ }^{81}$, obtiveram, in vitro, uma redução de $21 \%$ na condutividade hidráulica após a aplicação do hidróxido de cálcio.

Ao hidróxido de cálcio é ainda atribuído o efeito neural, pois, supõe-se que o aumento da concentração de íons de cálcio ao redor das fibras nervosas provoca a redução da excitabilidade nervosa ${ }^{265}$. Essa hipótese é descartada na prática em decorrência da baixa 
solubilidade do hidróxido de cálcio que, assim, teria pouca possibilidade de liberar íons cálcio em quantidade suficiente para afetar a função dos nervos ${ }^{264}$.

Não se pode descartar o efeito de coagulação de proteínas proporcionado pelo elevado $\mathrm{pH}$ do hidróxido de cálcio como um dos fatores de modificação da condutividade hidráulica da dentina. A literatura não apresenta dados que comprovem essa possibilidade, mas espera-se que este produto tenha sobre os prolongamentos de Tomes o mesmo efeito cauterizador observado no tecido conjuntivo pulpar como nos casos de capeamento ou pulpotomia $^{203}$.

Segundo Levin, Yearwood e Carpenter ${ }^{122}$, em 1973, com a aplicação do hidróxido de cálcio na forma de pasta sobre a dentina hiperestésica durante três a cinco minutos, passivamente, sob brunidura com um bastão de madeira ou com taça de borracha, pode ser esperado um alívio imediato da hiperestesia dentinária em $75 \%$ dos casos tratados. Após seis meses, era de $98 \%$ a redução da hiperestesia, entretanto, $40 \%$ dos dentes do grupo controle tratados com água destilada estavam livre de hiperestesia, provavelmente, pelo mecanismo de defesa natural. Green, Green e McFall ${ }^{80}$, em 1977, após avaliação clínica indicaram, ao invés do nitrato de potássio, a aplicação de hidróxido de cálcio por cinco minutos em superfícies radiculares hiperestésicas.

Em relação à dentina tratada com hidróxido de cálcio, Brännström, Isacsson e Johnson ${ }^{28}$, em 1976, encontraram, microscopicamente, um grau variável de constrição nos túbulos dentinários de $0,1 \mathrm{~mm}$ de profundidade, considerando-a uma oclusão tubular pobre e temporária.

\section{Cloreto de estrôncio}

As avaliações do cloreto de estrôncio mostraram resultados variados com relação a sua efetividade ${ }^{7,81,133,236}$. Acredita-se que a aplicação de uma solução concentrada de cloreto de estrôncio na superfície da dentina exposta produz um depósito de estrôncio que se 
estende a uma profundidade de até $20 \mu \mathrm{m}$ no interior dos túbulos dentinários. Isto ocorre, provavelmente, devido à troca de cálcio da dentina pelo estrôncio, produzindo um novo complexo de estroncioapatita, reduzindo a condutividade hidráulica da dentina e, conseqüentemente, a hiperestesia ${ }^{203}$.

O cloreto de estrôncio é um sal neutro com toxicidade inferior à do cloreto de cálcio, além de ser altamente solúvel em água e de fácil emprego ${ }^{133}$. São encontradas no comércio algumas formulações à base de cloreto de estrôncio hexa-hidratato a 10 \%, apresentadas na forma de verniz ou, principalmente, dentifrícios ${ }^{110}$.

De acordo com Greenhill e Pashley ${ }^{\beta 1}$, em 1981, apesar de ter sido constatada a eficiência de dentifrícios contendo cloreto de estrôncio em pesquisas clínicas, estudos in vitro registraram que essa substância apenas reduz levemente o fluxo do fluido dentinário. Supõe-se que a redução da hiperestesia ocorre clinicamente, não por causa da incorporação do cloreto de estrôncio, mas, graças à oclusão dos túbulos pelas partículas abrasivas dos dentifrícios.

Meffert e Hoskins Jr. ${ }^{133}$, em 1964, contataram o alívio em $49 \%$ dos pacientes que escovavam os dentes com pasta dentifrício contendo $10 \%$ de cloreto de estrôncio. Já, Anderson e Matthews ${ }^{7}$, em 1966, aplicaram a solução de cloreto de estrôncio em preparos cavitários e não verificaram a redução da hiperestesia. Porém, contestaram os resultados alegando que as condições nas quais a hiperestesia cervical ocorre são diferentes das encontradas num preparo cavitário.

Shapiro et al. ${ }^{236}$, em 1970, após compararem o cloreto de estrôncio e o monofluorofosfato de cálcio a 0,76\% em dentes hiperestésicos, concluíram que apesar do cloreto de estrôncio proporcionar redução da hiperestesia mais rapidamente, ao final de oito semanas, não notaram diferenças entre os dentifrícios. De um modo geral, creditaram ao dentifrício com cloreto de estrôncio os melhores resultados. E, ainda, alguns pesquisadores verificaram que a aplicação de cloreto de estrôncio a 10\% seguido da utilização de fluoreto 
de sódio a $2 \%$ foi mais efetiva na redução da hiperestesia do que o fluoreto de sódio isoladamente ${ }^{68}$.

\section{Fosfato de Cálcio}

Sendo o fosfato de cálcio o principal componente da dentina, Suge ${ }^{248}$ et al., em 1995 e Kawasaki ${ }^{111}$ et al., em 1996, consideraram natural que os túbulos fossem ocluídos com este mineral. Sugeriram, então, que o método de precipitação da solução de fosfato de cálcio, acidificada com ácido fosfórico, seguida pela neutralização com uma solução básica, à base de fluoreto e hidróxido de sódio, tem potencialidade para o tratamento da dentina hiperestésica. A precipitação imediata de fosfato di-cálcio di-hidratado, podendo atingir uma profundidade de 10 a $15 \mu \mathrm{m}$ no interior dos túbulos, demonstra o valor potencial do método para a oclusão dos túbulos dentinários, reduzindo imediata e significativamente a permeabilidade dentinária após o tratamento ${ }^{103,111,248,249,250}$.

Neste contexto, o papel do fluoreto de sódio é, segundo Kawasaki et al. ${ }^{111}$, em 1996, alterar o precipitado de fosfato di-cálcio di-hidratado para um mineral apatítico. No ambiente in vivo, devido ao fluxo de fluido dentinário e a pressão pulpar, há a possibilidade do fosfato di-cálcio di-hidratado dissolvido se perder. Portanto, é desejável a transformação do precipitado em fluorhidroxiapatita, mais resistente à dissolução ácida. Suge et al. $^{250}$, em 1995, revelaram que a concentração de cálcio e fosfato no precipitado é maior quando o fluoreto de sódio está presente na solução pós-tratamento. Kawasaki et al. ${ }^{111}$, em 1996, chegaram a mesma conclusão após experimentarem a adição de hexafluorsilicato na solução de fosfato de cálcio, na tentativa de evitar que o mineral apatítico fosse formado apenas na superfície dentinária, remanescendo o precipitado de fosfato di-cálcio dihidratado no interior dos túbulos dentinários.

Suge et al. ${ }^{248}$, em 1995, constataram que a permeabilidade após o tratamento da dentina com o método de precipitação de fosfato de cálcio permanece baixa mesmo após 
um período de imersão em saliva sintética. Além de, microscopicamente, após este tempo, não observarem linha demarcatória entre o precipitado de apatita e a dentina intertubular, indicando sua mineralização. A imersão do precipitado de apatita num volume fixo de saliva sintética explicou o fenômeno, pois a diminuição da concentração de íons cálcio e fosfato na saliva sintética indica a mineralização com o tempo do fosfato de cálcio no precipitado apatita. O método de precipitação do fosfato de cálcio teria, então, um efeito contínuo de redução da permeabilidade dentinária no ambiente oral.

Entretanto, Tung et al. $^{268}$, em 1993, apesar da diminuição da permeabilidade dentinária, não notaram formação de cristais no interior dos túbulos, e responsabilizaram a rápida formação de fostato de cálcio quando as soluções de cálcio e fosfato são misturadas, impedindo a subseqüente precipitação do fosfato de cálcio no interior dos túbulos, mostrando-a apenas na superfície. Ainda, Tung et al. ${ }^{267}$, em 1997, confiaram que a rápida mineralização do fosfato de cálcio amorfo pode ser alcançada após a aplicação das soluções de cloreto de cálcio e fosfato de potássio. In vitro, observaram a formação de fosfato de cálcio na superfície da dentina e a diminuição da permeabilidade e, in vivo, a redução da hiperestesia dentinária. No entanto, Yates et al. ${ }^{278}$, em 1998, in vivo, não observaram efeito terapêutico do fosfato de cálcio amorfo.

\section{Compostos fluoretados}

Em 1941, Lukomsky ${ }^{127}$, com os poucos recursos da época, foi o primeiro a acreditar que o flúor poderia tratar a hiperestesia dentinária. Os compostos fluoretados de modo geral, como o fluoreto de sódio, o fluorfosfato acidulado e o fluoreto estanhoso, agem de forma semelhante sobre o controle da hiperestesia dentinária, pois não ocluem completamente os túbulos dentinários, exigindo várias aplicações para que se obtenha um efeito significativo na redução da dor ${ }^{203,234}$. 
Quando em contato com as estruturas dentárias mineralizadas, as substâncias fluoretadas reagem quimicamente com os íons cálcio e fosfato proporcionando a precipitação de cristais de fluoreto de cálcio. Esses cristais formam-se especialmente na embocadura dos túbulos dentinários, cujo conteúdo líquido é rico em íons cálcio e fosfato, bloqueando os túbulos dentinários mecanicamente e prevenindo a transmissão do estímulo pelo mecanismo hidrodinâmico ${ }^{203,256,116}$. O fluoreto de cálcio é um composto bastante instável e se desassocia rapidamente após a aplicação, fazendo com que o efeito antihiperestésico dos fluoretos seja, via de regra, de curta duração ${ }^{203}$. Apenas uma pequena fração dos fluoretos aplicados sobre a dentina é retida sob a forma insolúvel de fluorapatita, o que pode tornar a dentina mais resistente ao efeito solubilizador das dietas ricas em ácidos ${ }^{60,116,203,256,285}$.

Entretanto, observa-se que as pesquisas referentes ao uso dos fluoretos mostram resultados conflitantes ${ }^{203}$. Pereira et al. $^{204}$, em 1990, verificaram que a aplicação de fluorfosfato acidulado a $1,23 \%$ na superfície dentinária exposta por quatro minutos, uma vez por semana, durante quatro semanas eliminou a hiperestesia em cerca de $65 \%$ dos dentes tratados, mantendo essa condição de normalidade por três meses. No estudo de Greenhill e Pashley ${ }^{81}$, em 1981, a aplicação de fluoreto de sódio a $2 \%$ reduziu a permeabilidade dentinária em $17,77 \%$, e de fluoreto de sódio acidulado em $24,5 \%$, pois a adição de ácido fosfórico neste último descalcifica a dentina, elevando a concentração de cálcio ionizado a um ponto que excede a constante de solubilidade do fluoreto de cálcio que, então, é precipitado sobre e no interior dos túbulos. Porém, segundo Trowbridge e Silver ${ }^{265}$, em 1990, é perdido rapidamente após sua aplicação na dentina.

De acordo com Brännström, Isacsson e Johnson ${ }^{28}$, em 1976, ao microscópio eletrônico de varredura, não foi detectado qualquer sinal de obliteração dos túbulos dentinários em superfícies tratadas com fluoreto de sódio. Também, os microrradiogramas não indicaram aumento de densidade em comparação às áreas não tratadas. Pashley ${ }^{164}$, 
em 1986, concorda que o fluoreto de sódio aplicado na forma de gel ácido ou neutro age, aparentemente, formando cristais insolúveis de fluoreto de cálcio. Contudo, como os cristais produzidos durante 2 a 4 minutos de aplicação são muito pequenos, cerca de 0,05 $\mu \mathrm{m}$, a permeabilidade e a hiperestesia não são reduzidas.

A maior parte das investigações analisa os fluoretos na forma de dentifrícios para o tratamento da hiperestesia. Deve-se ressaltar que os componentes abrasivos destes produtos, geralmente à base de cálcio e sílica, são vistos tanto na superfície dentinária quanto dentro dos túbulos, sugerindo, segundo Ling et al. ${ }^{124}$, em 1997, certo potencial terapêutico desses componentes. Também, Absi, Addy e Adams ${ }^{3}$, em 1995, indicaram que o efeito oclusivo dos dentifrícios é quase certamente produzido pelos componentes abrasivos. Entretanto, apesar dos dentifrícios formarem um depósito granular inicial na superfície dentinária, ocluindo parcial ou totalmente os túbulos dentinários, são removidos facilmente durante a lavagem. Também Ide ${ }^{101}$, em 1994, mostrou que os componentes abrasivos em conjunto com a escovação produzem uma redução da área da abertura do túbulo quando visto microscopicamente, mas nenhuma redução no número de túbulos abertos. Collaert e Fischer ${ }^{44}$, em 1991, sugerem o fluoreto de sódio na forma de dentifrício é ineficiente no tratamento da hiperestesia dentinária.

Para Addy e Mostafa ${ }^{4}$, em 1988, a ação in vitro do fluoreto de sódio na oclusão dos túbulos dentinários não é permanente. Explicam que, mesmo havendo uma precipitação ou reação inicial com a superfície dentinária, o flúor parece se dissolver facilmente em um ambiente aquoso. A despeito disso, in vivo, mediado por componentes salivares, o efeito pode ocorrer. Para os autores, aí estaria a explicação para a aparente eficiência dessa substância no tratamento da hiperestesia dentinária. Do ponto de vista de Krauser $^{116}$, em 1986, o uso dos fluoretos como agentes anti-hiperestésicos é encorajador, apesar da hiperestesia continuar presente mesmo onde a população já vem utilizando, há muitos anos, pastas dentifrícias contendo flúor. 
O fluoreto de estanho tem se mostrado eficaz na redução da hiperestesia dentinária. Blong et al. ${ }^{16}$, em 1985, mostraram sua efetividade na forma de gel a $0,4 \%$ por até quatro semanas após o tratamento. Entretanto, o uso do fluoreto estanhoso é limitado devido ao seu alto custo, curto prazo de validade, além de poder induzir manchas nos dentes. Addy e Mostafa ${ }^{4}$, em 1988, estudaram a ação in vitro deste material na oclusão tubular. Relataram que, se houve uma reação ou precipitação inicial, se desfez quando em meio aquoso. Conforme esclareceram os autores, os bons resultados clínicos podem ocorrer pelo efeito mediador indireto dos componentes salivares, o que pode explicar a aparente eficiência do material.

\section{lontoforese}

A iontoforese, também chamada de cataforese, ionoforese ou eletroforese, é um método terapêutico que proporciona a transferência de íons sob pressão elétrica para a superfície do tecido ${ }^{65}$. Nos casos de hiperestesia dentinária, emprega-se a iontoforese do flúor com a finalidade de possibilitar a penetração de íons flúor mais profundamente nos túbulos dentinários. O processo envolve a utilização de um eletrodo negativo aplicado sobre a dentina, enquanto o eletrodo positivo é seguro pelo paciente, fazendo com que seja fechado um circuito elétrico que permite a passagem de uma corrente de aproximadamente um miliampere, acelerando o transporte de íons para a dentina. $\mathrm{O}$ eletrodo negativo tem a forma de um pincel, carregado com fluoreto de sódio a 1-2\% ou fluoreto estanhoso a $2 \%$, $4 \%, 8 \%$, eletrólitos geralmente usados para os casos de hiperestesia ${ }^{64,65,203,265}$.

Gangarosa Sr. ${ }^{64}$, em 1994, esclarece que a ação iontoforética do flúor na hiperestesia dentinária pode ocorrer por dois mecanismos: através da precipitação intratubular do fluoreto de cálcio afetando a permeabilidade dentinária e/ou pelo efeito do flúor no mecanismo de condução nervosa sensorial. Explica que a aplicação tópica de flúor provoca a formação de fluoreto de cálcio apenas na superfície da dentina onde pode ser 
rapidamente dissolvido pela saliva, enquanto que a iontoforese permite que o fluoreto de cálcio atinja maior profundidade no interior dos túbulos, podendo reagir formando fluorapatita.

Além de ser um procedimento que envolve a utilização de um aparelho específico, bastante suscetível às condições locais do dente envolvido, tem sido demonstrado que a efetividade deste processo não se diferencia muito dos métodos tradicionais de aplicação dos fluoretos que apresentam melhor relação custo-benefício ${ }^{64,137}$. Entretanto, Greenhill e Pashley $^{81}$, em 1981, observaram a redução da condutividade hidráulica da dentina in vitro utilizando a iontoforese de fluoreto de sódio a $2 \%$ é de $33 \%$, aproximadamente, enquanto a aplicação convencional da mesma solução reduz essa condutividade em apenas $17,77 \%$.

\section{Oxalato de potássio}

Sobre a história da utilização dos oxalatos, Pashley e Galloway ${ }^{181}$, em 1985, relataram que em 1945, já se iniciava o uso deste composto para proteger o esmalte do ataque ácido. Seqüencialmente, os depósitos de oxalato de cálcio foram percebidos quando os oxalatos foram adicionados à água de beber ou à comida. Concluíram que os ácidos oxálicos foram mais efetivos do que os fluoretos na prevenção in vivo da dissolução do esmalte por ácidos. No entanto, apesar dos oxalatos serem efetivos na redução da solubilidade do esmalte tanto in vivo quanto in vitro, ninguém tinha ainda examinado seus efeitos na dentina.

A literatura relata que o oxalato de potássio produz dois efeitos distintos na redução da hiperestesia dentinária, um imediato e outro mediato. O bloqueio dos túbulos por cristais caracteriza o efeito mediato e, a despolarização neural seria o efeito imediato do oxalato de potássio na dentina hiperestésica ${ }^{150}$. O mecanismo de ação do oxalato de potássio através do bloqueio ou redução do lúmen dos túbulos dentinários é defendida tanto por estudos in vitro $^{81,104,144,168,174,179,181,237,277}$ quanto in vivo ${ }^{46,59,112,114,150,248}$. Ao reagir com o cálcio ionizado 
da dentina e do fluido dentinário, o oxalato promove a deposição de cristais de oxalato de cálcio na superfície dentinária e/ou no interior dos canalículos, bloqueando as embocaduras dos túbulos tão eficientemente quanto a smear layer original, reduzindo de forma significativa a permeabilidade própria dessa estrutura ${ }^{181,184,160,203}$. Os cristais de oxalato de cálcio são insolúveis, identificados pela sua forma bipiramidal ou tetragonal, e mantêm a impermeabilidade da dentina mesmo após desafios subseqüentes com ácido cítrico a $6 \%{ }^{160,181}$.

O oxalato de potássio é, tipicamente, uma droga de efeito oclusivo sobre a dentina, embora alguns autores tenham sugerido a possibilidade da sobreposição de um efeito neural $^{91,113,207}$ Kim $^{113}$, em 1986, e Gillam et al. $^{70}$, em 1996, acreditam que a potencialidade anti-hiperestésica dessa substância deve-se à difusão do potássio através dos túbulos, aumentando a concentração deste íon ao redor das terminações nervosas próximas ao limite pulpodentinário, onde altera as trocas normais de sódio e potássio essenciais para a transmissão do impulso nervoso, tornando-as menos excitáveis. Essa hipótese foi reforçada por Pereira e Nicolau ${ }^{207}$, em 1993, ao não observarem, in vitro, a deposição de cristais na superfície dentinária em espécimes tratados com solução de oxalato de monopotássio mono-hidrogenado a $3 \%$, a mesma formulação com que conseguiram, em pesquisa clínica $^{205}$, o controle da hiperestesia dentinária em $80 \%$ dos dentes tratados. Observaram, ainda, in vitro, que em determinados espécimes a deposição de cristais se restringia ao interior dos canalículos dentinários. Independentemente da forma de ação, os produtos à base de oxalato de potássio têm ganhado popularidade em razão dos resultados altamente promissores, obtidos tanto através de estudos tanto in vitro quanto in vivo ${ }^{91,150}$.

Pashley tem considerado para seus experimentos o uso combinado ou isolado de duas formulações à base de oxalato de potássio, o oxalato dipotássio a $30 \%$ e o oxalato de monopotássio mono-hidrogenado a $3 \%{ }^{150,219}$. Pashley e Galloway ${ }^{181}$, em 1985, esclareceram que o oxalato dipotássio a $30 \%$ produz menos cristais de oxalato de cálcio, 
porém maiores do que os produzidos pelo oxalato de monopotássio mono-hidrogenado. Postularam que os cristais maiores produzidos pelo oxalato dipotássio a $30 \%$ podem ser efetivos apenas na oclusão de túbulos dentinários abertos e amplos, podendo não ocluir os túbulos mais estreitos e parcialmente fechados. E que os cristais significativamente menores produzidos pelo oxalato de monopotássio mono-hidrogenado a $3 \%$ podem ser efetivos tanto na oclusão de túbulos abertos quanto parcialmente fechados.

Segundo Pashley e Galloway ${ }^{181}$, em 1985, e Kim $^{113}$, em 1986, a diferença na quantidade de produção dos cristais de oxalato de cálcio pode ser resultante da diferença de pH das duas soluções de oxalato de potássio. A solução de oxalato dipotássio a $30 \%$ possui $\mathrm{pH}$ relativamente neutro de 5,6, enquanto a solução de oxalato de monopotássio monohidrogenado a $3 \%$ tem $\mathrm{pH}$ 2,0. Pashley sugeriu que a solução de oxalato dipotássio a $30 \%$ reage com o cálcio ionizado disponível no fluido dentinário, produzindo cristais de oxalato de cálcio lentamente devido a limitada concentração do cálcio ionizado. Em contraste, a solução de oxalato de monopotássio mono-hidrogenado a 3\% age como um condicionador moderado, elevando a concentração de cálcio ionizado a níveis extremamente altos, que resulta na formação acelerada de cristais. Assim, as diferenças no tamanho e número de cristais produzidos pelas soluções de oxalato de potássio podem explicar a maior redução da hiperestesia encontrada in vivo por Muzzin e Johnson ${ }^{150}$, em 1989, quando utilizaram o oxalato de monopotássio mono-hidrogenado a 3\%, em relação ao oxalato dipotássio a 30\%.

A hidratação também afeta o tipo de cristal de oxalato de cálcio que se forma. O trihidratado é o precipitado inicial na formação tanto do cristal di-hidratado como do monohidrogenado. É bastante solúvel e instável. A forma di-hidratada requer uma quantidade excessiva de íons cálcio relativa aos íons oxalato que se precipitam com forma tetragonal ou octogonal. O cristal mono-hidrogenado é mais estável e aparece com forma de sino. Como as amostras examinadas são de dentes extraídos, a modificação da hidratação natural da dentina e a ausência do fluido dentinário devem ser consideradas como possíveis variáveis 
que afetam os precipitados comparados com os formados pela reação com a dentina in vivo $^{56}$.

Os comentários de Pashley ${ }^{160}$, em 1989, reforçam que o tratamento da smear layer com oxalato de monopotássio mono-hidrogenado a 3\%, provoca a remoção da smear layer original e sua reposição com uma camada de cristais de oxalato de cálcio muito pequenos e insolúveis que não modificam sua aparência quando desafiados com ácido cítrico a 6\%. Quando a smear layer original é tratada sucessivamente com oxalato dipotássio a $30 \%$ seguido do oxalato de monopotássio mono-hidrogenado a 3\%, a superfície se torna coberta com uma mistura de cristais grandes e pequenos que também resistem ao ataque ácido. Todos estes procedimentos reduzem a permeabilidade dentinária a níveis que são ainda abaixo daqueles obtidos na presença da smear layer. Pashley e seus colaboradores $^{81,164,217}$ sugeriram, então, que a ação anti-hiperestésica mais efetiva ocorre quando a aplicação do oxalato dipotássio a $30 \%$ é seguida pelo oxalato de monopotássio mono-hidrogenado a $3 \%$. Esses autores acreditam que se o excesso de oxalato dipotássio a $30 \%$ for deixado no dente quando o oxalato de monopotássio mono-hidrogenado a 3\% é aplicado, a solução a $30 \%$ pode agir como um tampão assim como um reservatório de oxalato adicional.

Outra informação importante foi fornecida por Yamamoto et al. ${ }^{277}$, em 1996, após o tratamento combinado da dentina de cães com as soluções de oxalato, a $30 \%$ e a $3 \%$. Relataram que a precipitação dos cristais de oxalato de potássio in vivo pode ocorrer não apenas na superfície dentinária, mas também nos túbulos dentinários, pois encontraram cristais localizados a 100 um da superfície, no interior dos túbulos dentinários.

Suge et al. $^{248}$, em 1995, constataram que a permeabilidade após o tratamento da dentina com oxalato de potássio aumentou gradualmente com o tempo de imersão em saliva sintética, diferente do que ocorreu com o fosfato de cálcio. A utilização do fluoreto de sódio a $2 \%$ e do cloreto de estrôncio a $10 \%$ acarretou no aumento da permeabilidade. 
Quando o oxalato de potássio foi aplicado, as fotomicrografias revelaram pequenos cristais ocluindo os túbulos dentinários que desapareceram após sete dias de imersão em saliva,. O aumento da permeabilidade dentinária pode ser explicado com os resultados obtidos com a imersão do oxalato de cálcio num volume fixo de saliva sintética. Observaram uma grande concentração de íons oxalato, indicando dissolução do oxalato de cálcio na saliva sintética e dessa forma, aumentando a permeabilidade dentinária.

O oxalato de cálcio é relativamente insolúvel, sua solubilidade é tão baixa quanto 0,58 mg por $100 \mathrm{~g}$. Se o oxalato de cálcio é imerso em saliva sintética, sua dissolução parcial deixa a solução em equilíbrio com respeito ao oxalato de cálcio, não havendo dissoluções futuras. No ambiente oral, o oxalato de cálcio continuamente entra em contato com nova saliva, que não contém íons oxalato, portanto, a dissolução continua lenta e constantemente $^{248}$. Essas observações são corroboradas por Kerns et al. $^{112}$, em 1991, que concordam que o oxalato de potássio significativamente reduz a hiperestesia dentinária, porém, seu efeito tem relativamente curta duração.

Tem sido mencionado que alguns agentes anti-hiperestésicos, entre eles o oxalato de potássio, interferem com o potencial adesivo de alguns sistemas restauradores. Pashley, Tao e Pashley ${ }^{201}$, em 1993, estudando adesivos dentinários e Haveman e Charlton ${ }^{88}$, em 1994, analisando cimentos ionoméricos químico e fotoativados, demonstraram que o tratamento prévio da dentina, na presença da smear layer, com formulações de oxalato de potássio, reduzem significativamente a resistência adesiva de materiais restauradores com capacidade de interagir com o substrato dentinário. Segundo estes autores, os cristais de oxalato podem impedir a íntima adaptação entre os materiais restauradores adesivos e a dentina tanto fisicamente, através da redução da retenção mecânica pelo bloqueio dos túbulos, quanto quimicamente, reduzindo a união química pela incapacidade de contato suficiente com a camada de troca iônica. Inclusive, as falhas adesivas foram muito mais freqüentes quando o oxalato de potássio foi utilizado ${ }^{88}$. Assim, se um procedimento 
restaurador com essas características for indicado, não se recomenda o tratamento prévio da dentina hiperestésica com aqueles produtos à base de oxalato de potássio, sem a remoção prévia da smear layer. Ou se recomenda a limpeza prévia da dentina com pedrapomes para remover os cristais de oxalato ${ }^{201}$.

Entretanto, Walker et al. ${ }^{270}$, em 1987, relataram que o comportamento do oxalato de potássio como forrador cavitário, sob restaurações de ionômero de vidro tradicional, pode promover uma favorável redução da permeabilidade dentinária, sem, no entanto, reduzir significativamente a resistência adesiva do ionômero com a dentina. Prati et al. ${ }^{212}$, em 1992, estudando um cimento forrador cavitário fotoativado, apresentaram resultados conflitantes com os estudos de Pashley, Tao e Pashley ${ }^{201}$, em 1993, e Haveman e Charlton ${ }^{88}$, em 1994 , relatando inclusive, um aumento da resistência adesiva quando o oxalato de potássio é utilizado previamente a aplicação dos materiais à base de ionômero de vidro.

E, ainda, os resultados da pesquisa de Richardson, Tao e Pashley ${ }^{219}$, em 1992, indicaram que o tratamento da dentina com oxalato de potássio previamente à cimentação de coroas, não alterou a resistência adesiva do ionômero de vidro e do policarboxilato, porém, quando foi utilizado o cimento de fosfato de zinco, a redução da resistência adesiva foi significante.

\subsubsection{Aplicação de película impermeabilizadora e procedimentos restauradores}

As lesões cervicais não cariosas podem apresentar-se como desgastes superficiais da dentina, com formato de pires, ou em forma de cunha, configurando uma destruição mais profunda da estrutura dentinária. Quando a lesão se apresenta com forma de pires, a preocupação pode se restringir ao controle da hiperestesia e às orientações do paciente quanto ao seu comportamento para evitar a progressão da lesão. Nas com formato de cunha, a profundidade e, não raro a extensão das lesões, comprometem a integridade da polpa e o aspecto estético, respectivamente. Nessas condições, os procedimentos 
restauradores adesivos, sejam os que empregam os cimentos de ionômero de vidro, ou os adesivos dentinários ou, ainda, sua combinação com as resinas compostas, constituem o recurso terapêutico mais conveniente e efetivo quando outros métodos tenham-se mostrado incapazes de controlar a hiperestesia dentinária ${ }^{203}$.

\section{Resinas fluidas e resinas compostas}

O tratamento da hiperestesia dentinária com a impregnação dos adesivos dentinários e resinas compostas é creditado ao selamento dos túbulos dentinários expostos, bloqueando imediatamente a transmissão do estímulo promotor da dor às terminações nervosas pulpares ${ }^{31}$.

Os primeiros trabalhos sugerindo o tratamento da hiperestesia com materiais resinosos iniciaram-se em 1979, com Brännström e seus colaboradores ${ }^{31,153}$, acreditando que a interação mecânica entre a dentina e uma resina convencional sem carga bloquearia a porção mais externa dos túbulos dentinários abertos e, assim, reduziria a atividade nervosa pulpar quando estimulada.

A partir de então, uma série de sistemas adesivos dentinários, primers e compostos resinosos têm sido investigados, tanto in vitro como in vivo, com relação à capacidade de penetrar e bloquear os túbulos dentinários, reduzindo ou eliminando a dor dentinária e caracterizando um potencial anti-hiperestésico: Scotchbond Multipurpose $e^{49,100,254,281}$, All-Bond $2^{69,281}$, Clearfil Liner Bond 2 $254,271,281$; Gluma Alternate ${ }^{49}$; Gluma $^{50,254}$; Gluma Desensitizer ${ }^{49,104}$, Pain-Free Desensitizer ${ }^{286}$; All-Bond DS ${ }^{104}$.

Experimentos clínicos diversos têm sido realizados com o intuído de garantir a efetividade do tratamento adesivo da hiperestesia dentinária. Um dos experimentos foi realizado por Suggs et al. ${ }^{251}$, em 1996, quando mostraram a redução de $95 \%$ da hiperestesia cervical após um único tratamento com adesivo dentinário. Mais de $90 \%$ dos pacientes não retornaram à condição de hiperestesia após 42 dias de controle. Outro 
estudo, foi divulgado em 1997, por Davidson e Suzuki ${ }^{50}$, no qual pacientes com hiperestesia de moderada à severa foram controlados durante um ano. Os resultados obtidos após o tratamento dos dentes com diferentes combinações de Gluma Cleanser, Gluma Primer e Gluma Sealer mostraram-se melhores do que nos dentes que não receberam tratamento.

Num estudo longitudinal realizado em 1998, Zhang et al. $^{286}$, observaram que uma emulsão resinosa, chamada Pain-Free Desensitizer, possui a habilidade de manter ocluídos os túbulos dentinários superficiais e profundos após um mês da aplicação deste material. Sugeriram que a oclusão dos túbulos pelo material anti-hiperestésico deveria ser longo o suficiente, isto é, de um a dois meses, para permitir uma reação físico-química natural e a oclusão os túbulos, mantendo a dentina livre da hiperestesia. Também Yoshiyama et al. ${ }^{279}$, em 1992, mostraram a oclusão dos túbulos dentinários com sistema adesivo penetrando mais de $5 \mu \mathrm{m}$ para o interior dos túbulos, e a manutenção deste bloqueio por meses, apesar de que as superfícies examinadas após seis meses não permaneceram com a cobertura resinosa, sugerindo a perda do material por métodos de higiene oral concomitantemente com a recorrência dos sintomas hiperestésicos.

Estudando os efeitos dos primers na hiperestesia dentinária, Watanabe et al. ${ }^{271}$, em 1991, reportaram que a solução aquosa de HEMA a 35\% exibiu um efeito anti-hiperestésico em dente de coelho, particularmente quando combinado ao adesivo dentinário. Quando o túbulo dentinário foi selado com o adesivo, o efeito anti-hiperestésico foi prontamente atendido, porém, não puderam explicar o mecanismo pelo qual a aplicação do primer reduziu a hiperestesia dentinária. In vitro, Simpson, Ciarlone e Pashley ${ }^{20}$, em 1993, confirmaram a habilidade de primers em ocluir a dentina e diminuir a permeabilidade. Em 1994, Tagami, Nakajima e Hosoda ${ }^{254}$, e em 1999, Dall'Orologio ${ }^{49}$, declararam que a aplicação dos primers, contendo glutaraldeído e HEMA, reagem com o grupo amino e provocam a precipitação de proteínas nos túbulos dentinários, produzindo um efeito 
imediato e reversível na redução da permeabilidade dentinária. Clinicamente, para tratar a hiperestesia dentinária, sugeriram a aplicação do primer seguida pelo adesivo dentinário. Ainda em 1994, Dijkman et al. ${ }^{51}$ esclareceram que o glutaraldeído fixa a smear layer de maneira que $50 \%$ dos túbulos permanecem fechados, mesmo após serem submetidos ao desafio com EDTA.

Jain et al. ${ }^{104}$, em 1998, experimentaram in vitro a ação de agentes antihiperestésicos à base de oxalato férrico e de potássio e, agentes à base de glutaraldeído e HEMA, o Gluma Dentin Dessensitizer, e o All Bond DS, que é um primer resinoso. Concluíram que, apesar dos agentes resinosos alcançarem os piores resultados de obstrução tubular, quando eram sujeitos aos efeitos da escovação e da saliva, o padrão de obstrução tubular foi aumentado ou mantido, mesmo sem haver mais sinais de cristais de oxalato de cálcio ou camada de primer na superfície. Sugeriram que, as superfícies dentinárias tratadas com alguns agentes anti-hiperestésicos, podem atrair e reter mais smear plugs do que as superfícies lisas e não tratadas.

Numa revisão sobre os estudos de permeabilidade dentinária e adesão, Pashley e Carvalho $^{162}$, em 1997, considerando também os estudos de Yoshiyama et al. ${ }^{281}$, em 1996, comentaram a dificuldade de se reproduzir in vitro as características de permeabilidade dentinária e de pressão pulpar encontradas in vivo. Observaram que, clinicamente, o tipo de substrato dentinário exposto à adesão é, freqüentemente, uma superfície anômala, afetada por cárie ou esclerótica em lesões cervicais. As pesquisas comparando a resistência adesiva destes dois tipos de substrato com a dentina normal mostraram que tanto na superfície afetada por cárie como na esclerótica por abrasão, a adesão é cerca de $30 \%$ menor do que na dentina normal. Presumivelmente, essas superfícies, esclerótica por cárie ou por abrasão, exibem mineralizações que ocluem os túbulos dentinários, diminuindo a permeabilidade intratubular e prevenindo a formação dos tags de resina. Ressaltaram que este tipo de dentina esclerótica permite menor formação de tags e, em lesões em forma de 
cunha, a camada híbrida é mais delgada. Porém, a camada híbrida formada em dentina afetada por cárie é mais espessa do que a formada na dentina normal. E, ainda, que os condicionadores ácidos em lesões cervicais parecem produzir um condicionamento superficial, provavelmente devido ao aumento do conteúdo mineral e menor solubilidade dessas lesões constantemente expostas a ciclos de desmineralização e remineralização na presença da saliva. Portanto, a retenção de restaurações de classe $\mathrm{V}$ em dentina esclerótica pode ser facilitada pelo condicionamento ácido e pelo primer que irá condicionar a dentina mais profundamente, produzindo uma melhor infiltração da resina e uma camada híbrida mais espessa.

Na mesma linha de raciocínio, Zhang et al. $^{286}$, em 1998, ressaltaram que se não houver perda de estrutura dental, não haverá espaço para cobrir a fina camada de adesivo dentinário com uma camada protetora de resina, tornando estes filmes de resina suscetíveis à perda pela escovação. Também argumentaram que isto não deve ser um problema se o tratamento formar tags resinosos que se estendam para o interior dos túbulos dentinários e sejam firmemente hibridizados nas paredes dos túbulos. Nestes casos, a perda do filme resinoso deixa os tags de resina no interior dos túbulos, mantendo a oclusão dos túbulos e a dessensibilização.

Em dentes com perda acentuada de estrutura dental na área hiperestésica, a associação dos adesivos dentinários e resinas compostas se torna possível. Investigações neste sentido foram conduzidas por Heymann et al. $^{90}$, em 1990, quando estudaram o comportamento clínico dos adesivos dentinários e ce diferentes resinas compostas em cavidades cervicais. A hiperestesia dentinária de $21 \%$ no pré-operatório, caiu para $10 \%$ após seis meses e, após dois anos, para 1\%, sem evidenciar diferenças entre os materiais empregados. O tratamento restaurador de lesões cervicais com combinações de cimento de ionômero de vidro, adesivo dentinário e resina composta foi também analisado por Powell, Gordon e Johnson ${ }^{210}$, em 1990, que observaram uma redução na hiperestesia dentinária 
em mais de $50 \%$ dos casos. Segundo os autores, a persistência da dor em alguns pacientes pode estar relacionada com a abertura dos túbulos dentinários pelo ácido poliacrílico e à contração da resina composta, que pode acabar permitindo a exposição dos túbulos e a movimentação do fluido dentinário.

As investigações sobre os fatores que influenciam no sucesso das resinas compostas e dos adesivos dentinários em lesões cervicais foram continuadas por Powell. Jonhson e Gordon ${ }^{211}$, em 1995, que ressaltaram o esforço oclusal excessivo e a flexão dental como contribuintes da perda da adesão entre dente e restauração. Em sua pesquisa, os autores notaram dentes com restaurações deslocadas exibindo facetas de desgaste oclusal, evidenciando a relação flexão dental e falta de retenção. Deste modo, consideraram válido pressupor que a técnica restauradora deve estar associada ao ajuste oclusal. Essas considerações foram corroboradas posteriormente pelas observações de Garone, em 1996.

\section{Cimento de ionômero de vidro}

Em 1979, Charbeneau e Bozel ${ }^{40}$ notaram uma redução da hiperestesia dentinária aos estímulos tátil e térmico quando avaliaram clinicamente o desempenho do cimento de ionômero de vidro em restaurações cervicais. Brandau, Ziemiecki e Charbeneau ${ }^{23}$, em 1984, também relataram que após quatro anos e meio da restauração das lesões cervicais pôde-se notificar a diminuição ou eliminação da hiperestesia.

As investigações clínicas de Russo ${ }^{223}$ e Conceição, Scur, Vidor ${ }^{45}$, ambos em 1994, demonstraram que os resultados favoráveis do ionômero de vidro como tratamento de lesões cervicais hiperestésicas permaneceram inalterados após um ano da restauração.

\subsubsection{Luz Laser}

Alguns tipos de lasers de baixa potência como o Nd:YAG, $\mathrm{He}: \mathrm{Ne}, \mathrm{CO}_{2}$, Ga:Al:As e Argônio têm sido empregados em tecidos duros, especialmente no tratamento da dentina 
hiperestésica $^{136,274}$. Segundo Myers e McDaniel ${ }^{151}$, em 1991, tem sido demonstrado clinicamente que a hiperestesia dentinária é eliminada ou drasticamente reduzida por períodos de até três anos com uma única aplicação de laser. Embora não sejam vistas alterações macroscópicas na superfície dentinária provocada por luz laser, estudos com microscopia eletrônica de varredura indicam claramente que a luz laser é capaz de modificar morfologicamente a superfície dentinária dependendo da energia aplicada ${ }^{74,199,230}$.

Os aparelhos de laser de dióxido de carbono emitem uma grande quantidade de energia a uma área restrita da superfície dentinária. A energia absorvida é transformada em calor, podendo queimar, derreter ou vaporizar os constituintes orgânicos e fundir os minerais, deixando os túbulos dentinários selados e impermeabilizados. Entretanto, como a temperatura é muito alta, pode haver a formação de crateras durante o resfriamento dos tecidos, tornando-os mais permeáveis do que quando cobertos pela smear layer ${ }^{199}$. Segundo Pashley et al. $^{199}$, em 1992, quando a dentina é exposta a uma baixa energia, há um aumento da condutividade hidráulica, devido à perda parcial da smear layer e smear plugs superficiais. O nível de energia intermediário também aumenta a permeabilidade dentinária pela formação de crateras, que torna a dentina mais fina, superficialmente sem uniformidade e porosa, além de comunicar-se com os túbulos dentinários subjacentes. Se a emissão de energia for mais alta, a superfície das crateras torna-se vítrea e os túbulos dentinários selados. Entretanto, simultaneamente à diminuição da permeabilidade dentinária no interior das crateras, há um aumento da permeabilidade num raio de aproximadamente $100 \mu \mathrm{m}$ ao seu redor, pois neste local a smear layer é completamente removida.

$\mathrm{Na}$ literatura há publicações de experimentos, realizados in vivo, defendendo a efetividade do tratamento da dentina cervical hiperestésica com laser de dióxido de carbono. Moritz et al. ${ }^{147}$, em 1998, revelaram que a ausência de dor ou o índice de sucesso de $96,5 \%$ obtido em seus estudos foi confirmado pelas imagens de microscopia eletrônica de varredura, mostrando o completo fechamento dos túbulos dentinários. Zhang et al. ${ }^{287}$, em 
1998, declararam que todos os pacientes, após o tratamento com laser, tiveram alivio total imediato que se prolongou por três meses em $50 \%$ dos casos, sem danos térmicos à polpa.

Schaller, Weihind e Strub ${ }^{230}$, em 1997, concordaram que também o tratamento com laser de Nd:YAG, sob irradiações de energia mais devadas, provoca o efeito de crateras na superfície dentinária acompanhado pelo fechamento parcial dos túbulos no seu interior, o que em contrapartida, põe em questão a eficiência do tratamento.

$\mathrm{Na}$ tentativa de conseguir um tratamento mais efetivo para a hiperestesia dentinária, o efeito combinado de alguns tratamentos tem sido estudado com sucesso. Lan, Liu e Lin ${ }^{117}$, em 1999, sugeriram a associação do verniz de fluoreto de sódio e da irradiação dos túbulos dentinários com Nd:YAG laser, proporcionando, in vitro, a oclusão de $90 \%$ dos túbulos dentinários, que se manteve mesmo após a escovação elétrica. Wichgers e Emert $^{274}$, em 1996, relataram que além do tratamento da dentina hiperestésica com laser isoladamente, também em associação com adesivos, é promissor. Estudos comprovaram o aumento da resistência adesiva após o tratamento da dentina com laser de argônio e $\mathrm{Nd}: \mathrm{YAG}^{273}$, sendo que com laser de dióxido de carbono esse aumento foi de $300 \%{ }^{274}$.

Como exposto por Pereira ${ }^{203}$, em 1995, com o aprofundamento dos estudos de aplicação da luz laser em Odontologia, a simplificação dos aparelhos e sistemas e a conseqüente redução de custo, este método deverá tornar-se um recurso acessível e extremamente útil para o tratamento das diversas afecções que acometem a cavidade bucal, inclusive a hiperestesia dentinária.

\subsection{Dessensibilização Natural e a Smear Layer}

A oclusão natural dos túbulos dentinários abertos pode ocorrer por intermédio da formação de cálculos, cristais intratubulares provenientes de minerais salivares e do fluido dentinário, cáries, dentina peritubular, colágeno, proteínas plasmáticas amplas, ou dentina 
reacional ${ }^{47}$. Outro mecanismo de oclusão tubular é a smear layer, descrita por Boyde et al., em 1963, é um filme de resíduos microcristalinos deixado no tecido mineralizado radicular ou coronário, criada quando os tecidos dentais são cortados ou abrasionados, tanto com instrumentos rotatórios como manuais, como no preparo de cavidades ou na raspagem periodontal ${ }^{58}$. A remoção in vivo dessa camada de resíduos microcristalinos expõe as embocaduras dos túbulos e aumenta a permeabilidade e a hiperestesia dentinária ${ }^{107,190}$. $\mathrm{O}$ efeito dos componentes da dieta na smear layer e no padrão dos túbulos têm sido investigados e mostraram que alimentos e bebidas ácidas produzem túbulos abertos em amostras de dentina in vitro'.

De acordo com Pashley ${ }^{160,161}$, clinicamente, a smear layer resulta do desgaste, escovação, aglomerações de proteínas, placa, etc. Contudo, os microorganismos da placa dental podem produzir ácidos orgânicos durante a glicólise suficientes para causar a dissolução da smear layer, assim como os ácidos da dieta também são capazes de removêla. Portanto, a longevidade da smear layer depende, provavelmente, das condições de sua criação e de seu ambiente e, com sua perda, a dentina exposta se torna mais permeável e sensitiva ${ }^{1}$.

A caracterização da composição química e do tamanho das partículas dos constituintes da smear layer foi primeiramente investigada por Eick et $a^{p^{8}}$, em 1970. Os resíduos, formados durante a criação da smear layer, são forçados para o interior dos túbulos dentinários à várias distâncias, constituindo o que se chama de smear plugs, mais longos na dentina profunda do que na superficial, por aquela possuir túbulos mais amplos $^{66,176}$. O exame da smear layer revela uma superfície amorfa, sendo que as partículas que a compõem, por serem muito pequenas, estão abaixo da resolução da microscopia eletrônica de varredura ${ }^{160}$. As partículas tem uma enorme área de superfície ${ }^{160}$, o que fazem-na mais susceptível à dissolução do que a matriz dentinária intacta, especialmente num ambiente ácido ${ }^{181}$. 
A espessura da smear layer varia grandemente, aproximadamente de 1 a $5 \mu \mathrm{m}$, dependendo de como a dentina é cortada ${ }^{24}$. A smear layer mais espessa, em torno de 10 a $15 \mu \mathrm{m}$, é a produzida in vitro pelo disco de diamante ${ }^{190}$. As smear layers criadas na dentina esclerótica são mais ácido resistentes do que as criadas na dentina normal porque muitos túbulos da dentina esclerótica são preenchidos por cristais ácido-resistentes e outras formas menos solúveis de fosfato de cálcio. Isto é especialmente verdadeiro na dentina profunda onde a densidade dos túbulos, ou seja, o número de túbulos por $\mathrm{mm}^{2}$ é maior, assim como o diâmetro. Como cada túbulo contém o smear plug contíguo com a smear layer, pode-se predizer que a smear layer na dentina profunda é mais firmemente ancorada na matriz dentinária do que na superficial ${ }^{257}$. As partículas formadoras da smear layer estão aderidas umas nas outras e com a dentina por colágeno gelatinoso e/ou outra proteína ou proteoglicanas, sob forças coesivas estimadas na ordem de 5 a $6 \mathrm{Mpa}^{176}$.

A presença da smear layer e smear plugs diminui a área de superfície da dentina para difusão de solutos dentinários ${ }^{52,185}$. Apesar da aparência microscópica dessas estruturas sugerir que são impermeáveis, estudos de Pashley e colaboradores ${ }^{167,174,185}$ com radioisótopos mostraram que são solúveis a moléculas tão grandes quanto a albumina. Ademais, muitos estudos ${ }^{167,174,185,217,196}$ indicam que a smear layer reduz grandemente a permeabilidade dentinária, sendo que Pashley, Livingston e Greenhilli ${ }^{186}$, em 1978, quantificaram em $86 \%$ a resistência total que a smear layer oferece ao movimento do fluido através da dentina. Assim, a smear layer também pode proteger a polpa de forças hidrostáticas e hidráulicas geradas durante a mastigação ou durante a cimentação de peças protéticas $^{29}$.

A menos que os autores indiquem que a superfície dentinária foi condicionada com ácido ou tratada com soluções quelantes, pode-se concluir que há uma smear layer presente na dentina sempre que o dente é preparado. Brännström e colaboradores ${ }^{24,31}$ sugeriram que a remoção da smear layer sem, no entanto, remover os smears plugs do seu 
interior seria o ideal, porém difícil de alcançar clinicamente. E, ainda têm-se informações de que a remoção da smear layer pelo condicionamento ácido ${ }^{31,33,190}$ não provoca injúria à polpa $^{24}$, especialmente se forem ácidos diluídos por curtos períodos de tempo.

Assim, as propriedades de permeabilidade da smear layer têm sido exaustivamente estudadas. Pashley usou a condutividade hidráulica para mensurar a permeabilidade da dentina coberta com a smear layer que é, na realidade, a medida da facilidade com que a água pode se mover através da unidade smear layer/smear plug ${ }^{162}$. A presença de smear plugs e smear layer diminui a condutividade hidráulica da dentina ${ }^{62,217}$, pois promove uma barreira para a movimentação do fluido e diminui a hiperestesia dentinária ${ }^{167,168,180,181,190}$. Contrariamente, quando a smear layer é perdida ou removida, a dentina exposta se torna mais permeável e sensitiva ${ }^{91,107}$. Clinicamente, o tratamento dessas superfícies sensitivas é intencionado na reoclusão dos túbulos com outra smear layer, com resinas ou com agentes que recolocam a smear layer como uma estrutura ácido resistente ${ }^{31,33,181}$.

\subsection{0 .Estudos Clínicos}

\subsubsection{Hiperestesia Dentinária}

Os experimentos clínicos sobre hiperestesia dentinária têm sido numerosos e os protocolos variados ${ }^{97}$. Infelizmente, até o momento há pouco consenso de como se conduzir os estudos, nos trazendo muita dificuldade para comparar seus resultados, muitas vezes contraditórios, e avaliar os vários tratamentos propostos para essa pouca compreendida porém comum e dolorosa condição dental.

Um comitê de pessoas interessadas discutiu os objetivos dos estudos clínicos sobre hiperestesia dentinária e um consenso foi apresentado. Foram recomendados grupos paralelos aleatórios de duplo cego, apesar de que grupos cruzados possam ser utilizados para a seleção preliminar dos agentes a serem estudados. Os pacientes selecionados devem possuir dentes hiperestésicos com diagnóstico clínico que satisfaça a definição da 
hiperestesia. O tamanho da amostra deve ser determinada estimando-se a variabilidade da população estudada, o efeito a ser detectado e a abrangência do teste estatístico a ser utilizado. A proposta selecionada deve ser baseada no diagnóstico clínico da hiperestesia dentinária, sendo que as faces vestibulares dos incisivos, caninos e pré-molares são os locais preferidos para serem estudados. É motivo de controvérsia, mas é importante a incorporação de controles negativo e de referência. Os experimentos, de preferência, devem ultrapassar oito semanas ${ }^{97}$.

Muitos estímulos provocam dor dentinária, mas nem todos são capazes de quantificar a hiperestesia dentinária. Pashley ${ }^{175}$, em 1990, referiu-se aos estímulos táteis, térmicos, evaporativos, elétricos e soluções osmóticas como sendo capazes de desencadear a dor dentinária. No consenso descrito por Holland et al. ${ }^{97}$, em 1997, consideraram que nos estudos clínicos deveriam ser aplicados pelo menos dois estímulos hidrodinâmicos e, dentre esses, o tátil e térmico evaporativo por serem ambos fisiológicos e controláveis. O tátil, representado pela sonda exploradora e o térmico evaporativo, pelo jato de ar, ambos acusados de provocar a movimentação rápida do fluido e ativar as terminações nervosas, provocando dor ${ }^{131,175}$. Um estudo in vitro de Pashley et al. ${ }^{169}$, em 1996, evidenciou que os estímulos que provocam maior movimento de fluido, em ordem decrescente, foram o calor, frio, jato de ar, soluções osmóticas e o estímulo tátil. Em suma, o estímulo deve ser mensurável, reproduzível e previsível.

A hiperestesia pode ser avaliada tanto em termos de intensidade de estímulo requerido para desencadear a dor, ou pode ser realizada uma avaliação subjetiva da dor produzida pelo estímulo, utilizando escalas visuais analógicas, de medida verbal ou outra escala apropriada e questionários específicos também podem ser utilizados para mensurar os estímulos ${ }^{71,97}$. Os métodos baseados no estímulo usualmente envolvem a medição do limiar da dor, e os baseados na resposta envolvem a estimativa da severidade da dor ${ }^{97}$. Estudos divulgam uma correlação entre as escalas entre si $^{71,87}$, porém não entre as escalas 
e o questionário ${ }^{87}$. Gillam, Bulman e Newman ${ }^{71}$, em 1997, confirmam que tanto as técnicas verbais como as não verbais podem quantificar os aspectos sensoriais e afetivos da dor. Os resultados devem ser expressos em termos de mudanças clinicamente significantes nos sintomas, além de serem requeridas avaliações de acompanhamento para determinar a persistência dessas mudanças ${ }^{97}$.

A dificuldade de execução e subjetividade são características inerentes dos estudos clínicos, que nos confundem com as diferentes metodologias empregadas, a dificuldade de mensuração da dor, a variabilidade dos resultados, e ainda, a influência do efeito placebo. Desses aspectos, é de particular curiosidade o fato da dor desaparecer com a aplicação de placebos. Várias investigações têm demonstrado o completo desaparecimento da dor em $20 \%$ a $45 \%$ dos pacientes tratados com substâncias inativas ${ }^{46,59,70,96,115,169,205,206}$. Trowbridge e Silver $^{265}$, em 1990, explicam que uma relação positiva entre o paciente e o seu dentista pode estimular o alívio da dor. Por outro lado, respostas emocionais e comportamentais positivas podem ativar o sistema central de inibição da dor. Esse sistema modula o estímulo doloroso da periferia pela liberação de endorfinas em nível central.

A literatura é farta em estudos clínicos que analisam a eficácia de materiais variados de diferente natureza e composição, como os dentifrícios, soluções de bochecho, géis e adesivos empregados com técnicas diversas para o alívio da hiperestesia dentinária. Os estudos clínicos reportados a seguir, enfatizam os produtos alvo de nossa investigação, o oxalato de potássio e o fluoreto de sódio.

Os estudos clínicos mais significativos encontrados na literatura que reportam a atuação de diferentes formulações à base de oxalato de potássio na redução da hiperestesia dentinária são os descritos abaixo, publicados por em 1989 por Cooley e Sandoval ${ }^{46}$ e por Muzzin e Johnson ${ }^{150}$; por Pereira et al. ${ }^{204,205}$ em 1990 e em 1994; por Holborow $^{96}$, em 1994 ; Estrela et al. ${ }^{59}$, em 1996; Gillam et al. ${ }^{70}$ e Sobral ${ }^{241}$, em 1997; 


\section{Carvalho e Dias ${ }^{38}$, Morris, Davis e Richardson ${ }^{148}$, e Pereira e Martineli ${ }^{206}$, publicaram em 1999.}

O estudo de Cooley e Sandoval ${ }^{46}$, em 1989, avaliou a efetividade das soluções de oxalato de potássio a $30 \%$ e de oxalato de monopotássio mono-hidrogenado a 3\% na redução da hiperestesia dentinária, quando comparadas à água destilada, todos aplicados por dois minutos. Este estudo envolveu 28 indivíduos com dentes sensíveis, avaliados no intervalo de uma semana, um mês e três meses. Para a avaliação do grau de hiperestesia foi utilizada uma escala verbal de 0 a 5, aplicada após o estímulo da água gelada ingerida pelo paciente. Todos os dentes experimentaram um significante decréscimo inicial da hiperestesia. A hiperestesia dos dentes tratados com água permaneceu aproximadamente a mesma ao longo dos três meses de estudo, enquanto nos dentes tratados com oxalato, progressivamente aumentou durante este período. Aos três meses, não houve diferença significante na hiperestesia dos dentes tratados com oxalato com os valores obtidos antes do tratamento.

Muzzin e Johnson ${ }^{150}$, em 1989, compararam os efeitos individual e combinado do oxalato de potássio a $30 \%$ e do oxalato monopotássio mono-hidrogenado a $3 \%$, aplicados durante dois minutos, na redução da hiperestesia dentinária in vivo. Selecionaram 17 pacientes, sendo a sensibilidade ao frio estabelecida inicialmente e imediatamente após a aplicação dos agentes, através da aplicação de água em diferentes temperaturas, nos períodos de uma, duas e quatro semanas após o tratamento. Notaram uma redução estatisticamente significante da hiperestesia no tratamento com oxalato monopotássio mono-hidrogenado a $3 \%$ nos tempos imediato e quatro semanas. No tratamento com oxalato dipotássio a $30 \%$ seguido de oxalato monopotássio mono-hidrogenado a $3 \%$, a redução significante ocorreu nos tempos de uma e duas semanas. Os resultados sugerem a diminuição da hiperestesia dentinária seguida da aplicação isolada de oxalato mono- 
hidrogenado a 3\% e, da aplicação combinada de oxalato dipotássio a 30\% e oxalato monohidrogenado a $3 \%$.

Em 1990, Pereira et $\mathbf{a l}^{\mathbf{2 0 4}}$, estudaram o efeito do oxalato de potássio a 3\%, $\mathrm{pH} 6$, em pacientes com hiperestesia dentinária na região cervical dos dentes, em comparação com outras técnicas anti-hiperestésicas, entre elas, a brunidura da dentina, o emprego do adesivo dentinário Scotchbond e fluorfosfato acidulado. Os autores observaram após o tratamento de 200 dentes, padrões de hiperestesia bastante reduzidos com os diferentes métodos empregados. Todos os dentes tratados com o oxalato de potássio apresentaram padrões de hiperestesia de zero a um, isto é, ausência de hiperestesia e hiperestesia mínima, após quatro aplicações, por um período de quatro meses.

Em outro estudo clínico, Pereira et al. $^{205}$, em 1994, verificaram diferentes padrões de hiperestesia dentinária frente a estímulos localizados, como ar, água e sondagem, mensurados por intermédio da escala de medida verbal, em 28 pacientes tratados periodontalmente. O Oxa-Gel, oxalato monopotássio mono-hidratado a $3 \%$, controlou a hiperestesia dentinária em cerca de $88,5 \%$ dos dentes, após quatro aplicações, uma por semana. Verificaram ainda que a hiperestesia permaneceu ausente ou com padrão mínimo mesmo após 8 meses de controle. Outro aspecto interessante observado por esses autores foi o controle da hiperestesia nos períodos iniciais de observação, em um percentual razoável de $76,8 \%$ dos dentes tratados com placebo.

O propósito do estudo de Holborow ${ }^{96}$, em 1994, foi avaliar a efetividade de uma solução à base de oxalato monopotássio mono-hidrogenado a $3 \%$, comercialmente denominado Butler Protect com pH 1,9-2,1, no tratamento da hiperestesia dentinária. Os 30 pacientes selecionados tiveram os dentes submetidos a testes de sensibilidade tátil e ao frio, e as respostas tabuladas utilizando a escala de severidade de 0 a 3 . As análises foram feitas imediatamente, 7,14 e 28 dias após ao tratamento. O oxalato de potássio, no $28^{\circ}$ dia de avaliação, mostrou redução significante na hiperestesia ao frio. Parece que o oxalato de 
monopotássio mono-hidrogenado pode contribuir no tratamento da hiperestesia radicular ao frio, sendo inconclusivo para o estímulo tátil por limitações metodológicas.

Estrela et al. ${ }^{59}$, em 1996, analisaram a redução da hiperestesia dentinária em 160 dentes, entre caninos e pré-molares, após tratamento periodontal, frente ao emprego dos seguintes produtos: fluoreto de sódio a $2 \%$, hidróxido de cálcio, Oxa-Gel, Duraphat, três sistemas adesivos e a água destilada como agente placebo. As avaliações, executadas no período de 7, 15, 30 e 60 dias, valeram-se de estímulos tátil e térmico, incluindo água fria e jato de ar. Com exceção dos sistemas adesivos que foram utilizados somente uma vez, os demais produtos foram novamente aplicados a cada período de observação. Os resultados indicaram que o hidróxido de cálcio e o fluoreto de sódio a $2 \%$ apresentaram os menores valores na redução da dor, enquanto que o Duraphat e o sistema adesivo Multibond Alpha, valores intermediários. O sistema adesivo Optibond e o Oxa-Gel demonstraram os melhores valores de redução de dor leve. E para uma dor acentuada, o Oxa-Gel e o sistema adesivo Scothbond Multi-Purpose Plus obtiveram os melhores valores. No grupo controle, mesmo empregando um agente placebo, verificou-se que para uma hiperestesia leve, aos 60 dias a redução de dor chega a $40 \%$.

Gillam et al. ${ }^{69}$, em 1997, compararam o adesivo All-Bond 2 e o produto Butler Protect, à base de oxalato de potássio em 55 dentes, tendo cada um deles um outro dente hiperestésico como controle. Os estímulos utilizados foram o tátil e o jato de ar, mensurados através da escala analógica verbal de 0 a 10, antes e depois de meio minuto, um, dois e três meses. Os resultados sugeriram uma redução da hiperestesia dentinária para todos os grupos e nenhuma diferença estatisticamente significante entre eles.

Sobral ${ }^{241}$, em 1997, identificou alguns aspectos da etiologia da hiperestesia dentinária cervical, classificando-a como abrasão, erosão ou abfração. Analisou também o efeito do verniz fluoretado, cimento de ionômero de vidro modificado por resina, oxalato de potássio (Oxa-Gel) e resina composta no tratamento da hiperestesia. Um total de 97 dentes 
com hiperestesia dentinária cervical, foram examinados em cinco ocasiões: antes do tratamento e uma semana, duas semanas, dois meses e quatro meses após o tratamento. $\mathrm{O}$ fator etiológico mais freqüentemente associado à dor dos dentes estudados foi a abrasão, seguida da abfração e da erosão. As técnicas empregadas foram efetivas na seguinte ordem: cimento de ionômero de vidro modificado por resina, resina composta, verniz fluoretado e oxalato de potássio. Os autores concluem que após a eliminação do fator etiológico e da aplicação de uma das técnicas selecionadas, existe uma tendência de regressão de hiperestesia dentinária cervical.

Carvalho e Dias ${ }^{38}$, em 1999, avaliaram a eficácia do flúor gel tópico acidulado, OxaGel e Arnica a 35\% em Orobase, no tratamento da hiperestesia dentinária. As soluções foram aplicadas em 45 pacientes a cada sete dias, durante quatro semanas. A hiperestesia dentinária foi avaliada após 30 e 60 dias. Não houve diferença estatística significante entre a arnica e o Oxa-Gel, que se mostraram tratamentos mais eficazes do que o flúor para o alívio da hiperestesia dentinária.

Morris, Davis e Richardson ${ }^{148}$, em 1999, compararam o efeito clínico de até três meses de dois agentes anti-hiperestésicos: uma suspensão resinosa pré-polimerizada contendo oxalato (Pain-Free), uma solução fluoretada a 0,7\% (DentinBloc), e água destilada como placebo. O nível de hiperestesia ao tato e ao jato de ar de cada um dos 52 dentes foi determinado utilizando a escala analógica visual, imediatamente, uma semana, um e três meses após o tratamento com os materiais. Todos os materiais utilizados, inclusive a água destilada, diminuíram a hiperestesia dentinária e, nenhuma diferença significante foi encontrada entre os materiais. Os autores concluíram que o Pain-Free e o DentinBloc foram efetivos na diminuição da hiperestesia dentinária por três meses e que nenhum tratamento foi mais efetivo do que o placebo.

Pereira e Martineli ${ }^{206}$, em 1999, avaliaram as respostas imediata e mediata de 94 dentes hiperestésicos, entre caninos e pré-molares, tratados com cada de uma das três 
formulações à base de oxalato de potássio: Oxa-Gel, Experimental 1 e Experimental 2, tendo um agente placebo como controle. O grau de hiperestesia foi avaliado de acordo com a escala de medida verbal, aos estímulos sonda e ar, antes e imediatamente após cada uma das quatro aplicações de três minutos dos agentes, com um intervalo de sete dias. A aplicação de todos os materiais, inclusive o placebo, resultou em uma redução estatisticamente significante na hiperestesia dentinária podendo essa redução prolongar-se até seis meses. Houve uma tendência de respostas mais severas ao estímulo ar quando comparado ao estímulo sonda antes do tratamento, sendo que a hiperestesia provocada pela sonda se mostrou mais persistente ao longo do tratamento.

Alguns dos estudos, detalhados a seguir, referentes a atuação dos fluoretos na redução da hiperestesia dentinária, foram publicados por Thrash, Jones e Dodds ${ }^{263}$, em 1992; Gillam et al. ${ }^{70}$, em 1996; e West et al. ${ }^{272}$, em 1997.

Thrash, Jones e Dodds ${ }^{263}$, em 1992, estudaram a duração do efeito antihiperestésico da solução contendo $0,71 \%$ de fluoreto com pH 3,5, comercialmente denominado DentinBloc; do Gel-Kam, à base de fluoreto estanhoso a 0,4\%, utilizando a água destilada como solução placebo, todos duas vezes por dia. Os 30 pacientes com hiperestesia ao jato de ar frio foram divididos em três grupos duplo cego. Os testes foram realizados às 2, 4, 8 e 16 semanas e os dados foram colhidos utilizando a escala analógica visual. Os resultados indicaram que o grupo que utilizou DentinBloc apresentou significativamente menor hiperestesia no período de duas semanas em relação aos outros grupos. Em adição, o grupo que utilizou a solução contendo fluoreto estanhoso a 0,4\% mostrou significativamente menor hiperestesia no período de quatro para oito semanas. A segunda fase do experimento utilizou DentinBloc durante 15 minutos, um dia, uma e duas semanas. Os resultados revelaram que os efeitos se apresentaram 15 minutos após a aplicação e continuaram ao longo dos testes. Concluíram que o DentinBloc foi um efetivo agente para o controle da hiperestesia dentinária após duas aplicações de um minuto. 
Gillam et al. $^{70}$, em 1996, compararam a efetividade de duas soluções de bochecho na redução da hiperestesia dentinária em 47 indivíduos por seis semanas, sendo um à base de nitrato de potássio a 3\%, sílica e fluoreto de sódio a $0,05 \%$, e outro, contendo apenas sílica e fluoreto de sódio a $0,05 \%$. Os pacientes foram instruídos para utilizar as soluções duas vezes ao dia e foram avaliados por intermédio da escala analógica verbal com estímulos táteis e com jato de ar, imediatamente e após duas e seis semanas do tratamento. Os resultados mostraram uma redução da hiperestesia dentinária cervical após a utilização do produto à base de nitrato de potássio a $3 \%$.

West et al. ${ }^{272}$, em 1997, estabeleceram, clinicamente, comparações entre três produtos denominados dentifrícios anti-hiperestésicos, um à base de estrôncio e outro à base de potássio, ambos contendo flúor, e um dentifrício convencional também com flúor. Um total 112 pacientes foi estudado, sendo que os estímulos utilizados foram o tátil e o jato de ar. O grau de hiperestesia foi mensurado através da escala analógica verbal após duas e seis semanas de uso dos dentifrícios duas vezes ao dia. Os resultados indicaram que os três agentes mostraram reduções na hiperestesia após seis semanas, porém, não houve diferença estatisticamente significante entre os grupos, em qualquer intervalo de tempo.

\subsubsection{Permeabilidade Dentinária}

Também os estudos clínicos, associados a outros métodos de análise, podem estudar aspectos morfológicos e funcionais da permeabilidade dentinária, como os de Yoshiyama e colaboradores ${ }^{280,281,282}$, em 1989, 1994 e 1996; Kerns et al. ${ }^{112}$ e Cuenin et al. ${ }^{47}$, em 1991; Oyama e Matsumoto ${ }^{158}$, em 1991 e o de Ciuchi et al. ${ }^{42}$, em 1995, que além de possibilitarem uma maior compreensão do substrato de atuação das substâncias, proporcionam dados para a determinação de metodologias de estudos laboratoriais que mais se aproximem das condições in vivo, e ainda, dão suporte a outros estudos clínicos. 
Estudando biópsias dentinárias radiculares removidas de dentes hiperestésicos in vivo, Yoshiyama et al. $^{282}$, em 1989, mostraram em microscopia eletrônica de varredura que muitos túbulos dentinários nas áreas hiperestésicas estavam abertos e estruturas membranosas apareceram em suas paredes internas. Nas áreas naturalmente não hiperestésicas da mesma superfície dentinária, a maioria dos túbulos dentinários estava obstruída com cristais romboédricos de todos os tamanhos, sendo que estruturas membranosas não foram observadas nesses túbulos. Esses resultados mostraram que a hiperestesia dentinária ocorre quando a maioria dos túbulos encontram-se abertos (Figuras 2 e 3).

O desenvolvimento de um método de avaliação in vivo das superfícies dentinárias, levou Kerns et al. ${ }^{112}$, em 1991, a estudar longitudinalmente a oclusão dos túbulos dentinários através de vários procedimentos clínicos incluindo raspagem e polimento radicular e aplicação de oxalato de potássio. Antes da extração, os dentes foram submetidos à raspagem com remoção de $1 \mathrm{~mm}$ da estrutura radicular. As seções foram tratadas com oxalato di-potássio a $30 \%(\mathrm{pH} 7)$ seguido de oxalato monopotássio mono-hidrogenado a 3\% (pH 2) e com EDTA a 0,5 M. Metade das seções de cada espécime foram incorporadas dentro de um desgaste na prótese removível, servindo a outra metade para controle. Os espécimes avaliados imediatamente no microscópio eletrônico de varredura não mostraram túbulos abertos devido à presença de smear layer ou cristais de oxalato. A avaliação de espécimes com a raiz polida revelou que aos sete dias os túbulos reabriram. Os espécimes que foram tratados com oxalato de potássio mostraram densa cobertura de cristais imediatamente, porém aos sete dias poucos cristais de oxalato permaneceram, revelando túbulos abertos. Os espécimes controle que foram condicionados com EDTA e deixados na prótese do paciente por 28 dias revelaram que, apesar do número de túbulos não ter se modificado significativamente, o diâmetro dos túbulos dramaticamente diminuiu na quarta semana. Pode-se concluir que a oclusão dos túbulos dentinários por intermédio da smear 
layer ou de cristais de oxalatos a fim de reduzir a hiperestesia é relativamente de curta duração, porém, estes procedimentos podem promover o conforto do paciente previamente à oclusão natural dos túbulos.
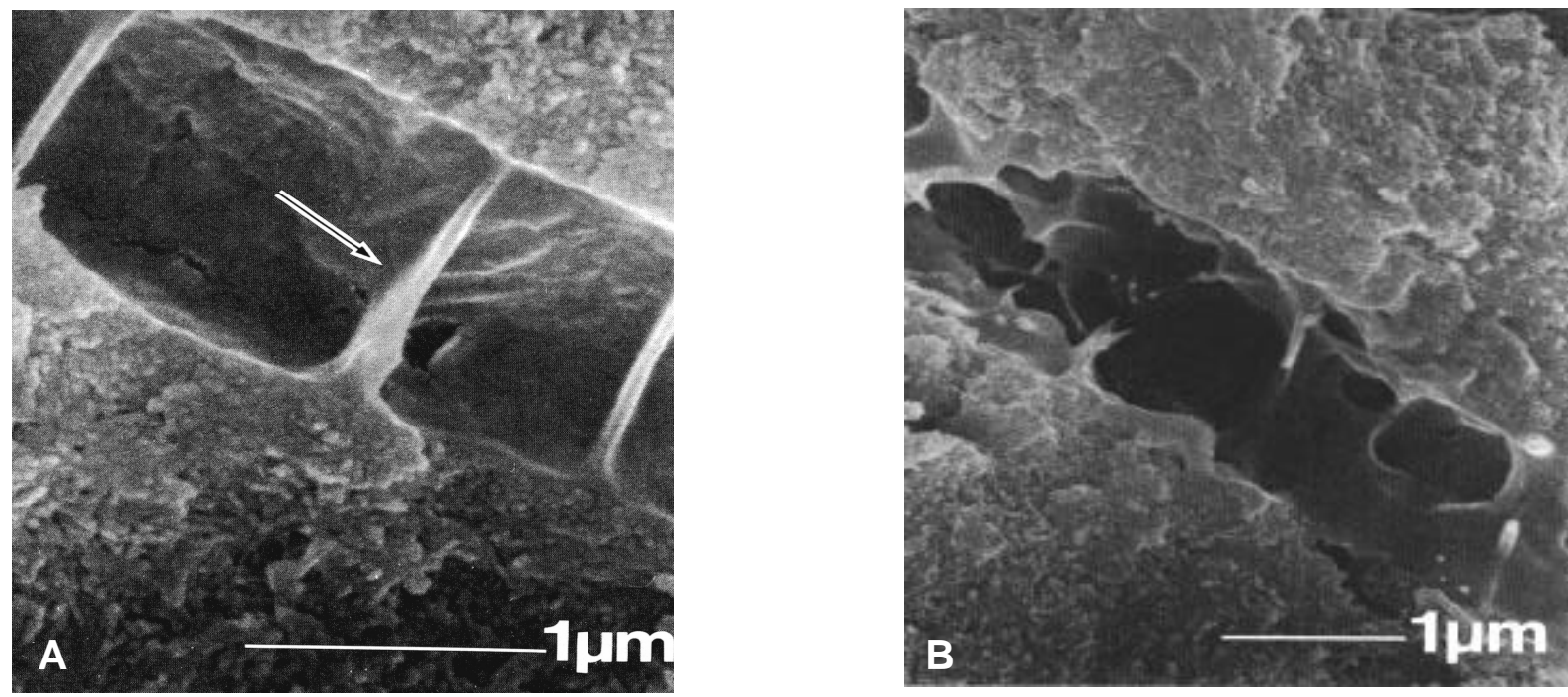

Figura 2 - A - Fotomicrografia de um túbulo dentinário de uma área hiperestésica. O lúmen do túbulo está repartido por estruturas membranosas; B - Imagem da estrutura membranosa forrando ao túbulo dentinário de uma área hiperestésica ${ }^{282}$.
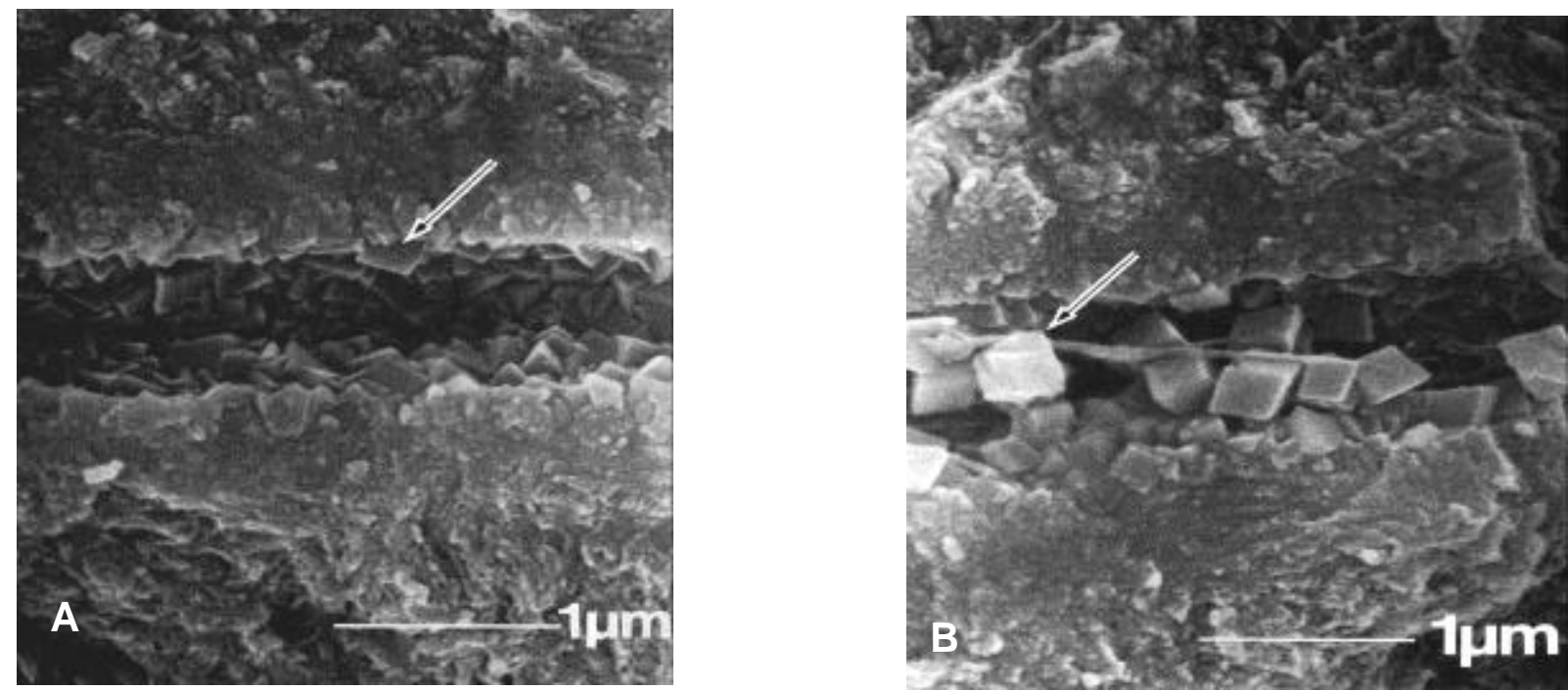

Figura 3 - A - Fotomicrografia de um túbulo dentinário de uma área naturalmente dessensibilizada. Cristais romboédricos de 0,1 a $0,3 \mu \mathrm{m}$ estão presentes; $\mathbf{B}$ - Imagem de amplos depósitos cristalinos no lumen do túbulo dentinário de uma área naturalmente dessensibilizada ${ }^{282}$. 
Para investigar a relação existente entre hiperestesia dentinária e o padrão de oclusão tubular in vivo, Cuenin et al. ${ }^{47}$, em 1991, examinaram clinicamente áreas de dentina exposta cervical em dentes sem sinais de patologia pulpar, através de estímulo com jato de ar traduzido pela escala numérica de 0 a 4 . A região foi, então, condicionada com EDTA a 0,5 M durante quatro minutos, a fim de providenciar a remoção da smear layer e a exposição dos túbulos. Os dentes foram analisados antes e depois do tratamento por 2 minutos com solução de cloreto de sódio a 3\% e com solução de oxalato de monopotássio mono-hidrogenado a $3 \%$, ambos com pH 2,4. A análise em microscopia eletrônica de varredura dos dentes extraídos revelou uma abertura tubular média de 1,720 $\mu \mathrm{m}^{2}$ após o tratamento com EDTA, 0,564 $\mu \mathrm{m}^{2}$ após o oxalato de potássio e $0,386 \mu \mathrm{m}^{2}$, após o cloreto de sódio. E a avaliação clinica mostrou o cloreto de sódio mais efetivo que o oxalato de potássio na redução da hiperestesia dentinária. Segundo os autores, o baixo pH da solução de cloreto de sódio pode ser um adjunto para o tratamento da hiperestesia dentinária.

A correlação entre a morfologia superficial dos túbulos dentinários e a hiperestesia dentinária foi analisada por Oyama e Matsumoto ${ }^{158}$, em 1991, através de réplicas de áreas dentinárias cervicais hiperestésicas de incisivos e molares, estudadas no microscópio eletrônico de varredura. Antes de serem feitas as réplicas de resina da dentina cervical, a superfície foi tratada alternadamente com álcool $70 \%$ e solução de hipoclorito a 5\%. O grau de hiperestesia dentinária foi medido por meio da escala de medida verbal de 0 a 3 , utilizando-se 0 jato de ar como estímulo. A dentina cervical hiperestésica também foi examinada com sonda exploradora e através de estímulo elétrico, sendo as áreas hiperestésicas fotografadas e comparadas com as réplicas. Os resultados mostraram que na dentina cervical hiperestésica percebem-se aberturas tubulares alargadas e, portanto, sugere-se uma correlação estatisticamente significante entre a morfologia dos túbulos dentinários e a hiperestesia. 
Observando a dinâmica da movimentação do fluido da dentina humana in vivo, Ciuchi et al. ${ }^{42}$, em 1995, estimaram a pressão pulpar do dente humano através da dentina intacta, determinando a pressão exógena requerida para anular o fluxo de fluido dentinário. As cavidades Classe V preparadas em pré-molares humanos, após a remoção da smear layer com ácido fosfórico a 37\%, foram adaptadas a uma câmara preenchida com solução salina e conectadas via túbulos um circuito hidráulico automatizado representado por um reservatório para o ajuste da pressão e por um equipamento para a medição da movimentação do fluido através da dentina (Figura 4). O dispositivo Flodec deste circuito apresenta receptores fotossensíveis que detectam deslocamentos mínimos de líquidos de até cinco micrometros, sendo os dados armazenados em um microcomputador. $\mathrm{Na}$ ausência da pressão exógena, a movimentação de fluido para o meio externo foi maior do que quando a pressão externa era aplicada à cavidade. A pressão externa que provocou o equilíbrio da movimentação do fluido foi de $14,1 \mathrm{~cm} \mathrm{H} \mathrm{H}_{2} \mathrm{O}$, considerada como sendo a mesma pressão interna da polpa.

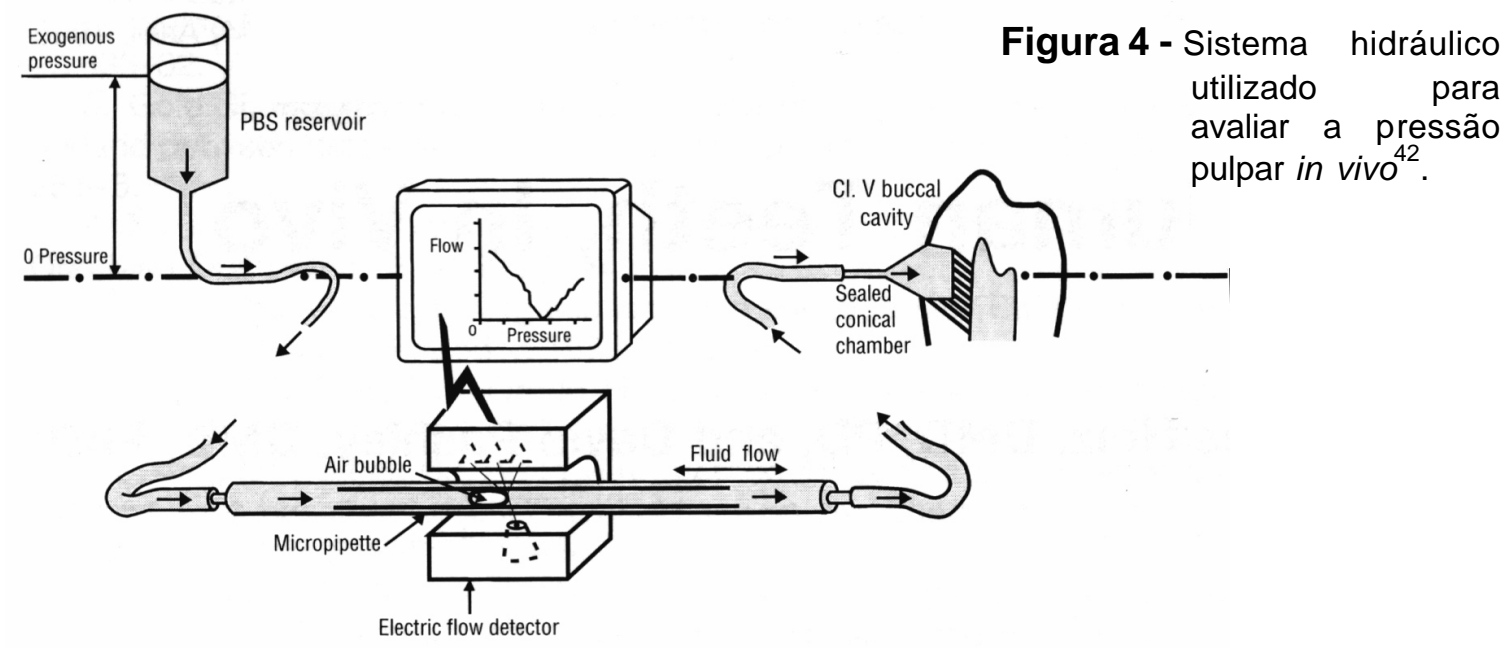


A partir dos estudos de 1989, Yoshiyama et al. ${ }^{280}$, em 1994, e Yoshiyama, Suge e Ebisu $^{284}$, em 1996, publicaram a existência de diferenças na distribuição de estruturas de forma tubular em áreas de dentes hiperestésicos e não hiperestésicos. As biópsias de regiões hiperestésicas apresentaram uma estrutura oca e tubular no interior de $75,8 \%$ dos túbulos, e em $20 \%$ na dentina não hiperestésica. Na maioria dos túbulos de áreas hiperestésicas, os processos foram detectados estendendo-se para a camada de subsuperfície a uma profundidade de 20 a $50 \mu \mathrm{m}$. Alguns autores sugerem que estes processos são extracelulares por natureza, outros consideram-nos processos odontoblásticos. E, afirmaram, que são responsáveis pela manutenção dos túbulos abertos, impedindo a oclusão espontânea, e mantendo dessa forma, a hiperestesia dentinária.

\subsection{Estudos de Permeabilidade Dentinária in vivo}

Apesar de consideráveis informações terem sido obtidas sobre as características de permeabilidade da dentina humana in vitro, estudos comparáveis na dentina humana in vivo são deficientes. Isto porque, alguns destes estudos requerem, por exemplo, o uso de isótopos radioativos, e não podem ser praticados em humanos. Segundo Pashley et al. ${ }^{173}$, em 1983, alguns estudos de Brännström indicaram que a dentina de humanos e de cães tem diâmetros tubulares similares de 1,4 e 1,3 $\mu \mathrm{m}$, respectivamente, medidos a meia distância entre a polpa e o esmalte, mas a densidade dos túbulos é maior em cães. Pashley humanos $^{128,167,170,172,173,182,192,277}$ e seus colaboradores contribuíram com informações valiosas utilizando o substrato dentinário de cães.

Ao comparar a permeabilidade dentinária de cães in vitro e in vivo no mesmo dente, Pashley et al. $^{167}$, em 1981, mostraram a rápida absorção iodo radioativo colocado na dentina sistemicamente via circulação pulpar e, indicaram uma grande similaridade entre os valores de permeabilidade in vivo e in vitro. Também, em 1981, Pashley, Nelson e Pashley ${ }^{192}$ desenvolveram um método para quantificar a movimentação do fluido dentinário 
pela medição da pressão pulpar através da dentina de cães in vivo. Descobriram que, apesar de haver a tendência da Lp ser mais baixa quando o fluido se movimenta da polpa em direção à superfície, a diferença não foi estatisticamente significante.

O experimento de Pashley et al. $^{173}$, em 1983, utilizando a mesma metodologia, determinou que o condicionamento com ácido cítrico a 6\%, durante dois minutos, aumenta em cinco vezes o movimento do líquido através da dentina de cães in vivo. Este valor é muito inferior ao aumento de 32 vezes, reportado por Reeder et al. ${ }^{217}$, em 1978, em dentina humana in vitro. Segundo os autores, a maior diferença entre os dois estudos, contribuindo para esta discrepância, é o fato dos discos de dentina humana serem preparados com disco de diamante que tende em aumentar a espessura da smear layer comparada à produzida in vivo, além de que os discos de dentina possuem smear layer em duas superfícies. Interpretaram ainda, que há uma relação inversa entre os valores de filtração iniciais, previamente ao condicionamento, e o percentual de modificação resultante após o condicionamento. Assim, a dentina com valor inicial de Lp alto, mostra o menor aumento após o condicionamento ácido.

Pashley et al. ${ }^{170}$, em 1983, observaram uma grande redução na permeabilidade dentinária em dentes de cães sete dias após a confecção de preparos cavitários, in vivo. Pashley et al. ${ }^{168}$, em 1984, repetiram a metodologia utilizada no ano anterior e verificaram uma queda progressiva, de aproximadamente $10 \%$, na permeabilidade dentinária de cães in vivo a cada hora das seis horas do estudo. Nenhuma mudança com o tempo foi observada em cães mortos ou nos que tiveram a polpa removida, levando a crerem que o decréscimo na permeabilidade dentinária em resposta a preparos cavitários está possivelmente relacionada às proteínas plasmáticas presentes no fluido dentinário e apenas ocorre em dentes com polpa intacta.

Pashley, Nelson e $\operatorname{Kepler}^{191}$, em 1982, sabendo que o fluido dentinário possui todas as proteínas encontradas no soro e no plasma, mostraram que as proteínas plasmáticas 
reduzem a permeabilidade dentinária in vitro, sendo o fibrinogênio o causador da maior redução. Pashley, Galloway e Stewart ${ }^{194}$, em 1984, repetiram novamente a metodologia utilizada por Pashley, Nelson e Pashley ${ }^{192}$, em 1981, em cães, verificando uma queda progressiva na permeabilidade de $50 \%$ em cães controle contra $15 \%$ nos que tiveram o plasma exaurido de fibrinogênio. Quando a solução de fibrinogênio foi filtrada através dos discos de dentina, sob pressão de $40 \mathrm{~cm} \mathrm{H}_{2} \mathrm{O}$, houve uma queda progressiva significativa da condutividade hidráulica em relação ao controle. Os resultados implicam que as proteínas plasmáticas, principalmente as de alto peso molecular como o fibrinogênio, são agentes que reduzem a permeabilidade dentinária in vivo.

Estudando o fluido dentinário, Maita et al. ${ }^{128}$, em 1990, determinaram que, em geral, a concentração protéica do fluido dentinário é aproximadamente a quinta parte da do plasma em condições espontâneas e decresce quando o fluxo é aumentado pela aplicação de pressões negativas externas. A pressão espontânea do tecido pulpar calculada foi de $42 \mathrm{~cm} \mathrm{H} \mathrm{H}_{2} \mathrm{O}$.

A maior parte dos estudos sobre a precipitação dos oxalatos tem sido desenvolvida in vitro, e pouco se sabe sobre a estabilidade dos cristais in vivo. Yamamoto et al. ${ }^{277}$, em 1995, examinaram a posição dos cristais precipitados em dentina de cães após o condicionamento ácido e o tratamento com oxalato de dipotássio a 30\% seguida de oxalato monohidrogenado a 3\%, in vivo. A análise microscópica mostrou numerosos cristais tanto na superfície como no interior dos túbulos dentro de uma distância de aproximadamente 100 $\mu \mathrm{m}$ da superfície. E que apesar do número de precipitados ser reduzido após uma semana de exposição à cavidade oral, muitos permaneceram nas porções mais profundas dos túbulos abertos e ampliados, apesar da presença da smear layer. Observaram também que quando a smear layer não foi removida antes do tratamento, todos os cristais estavam localizados na superfície e os túbulos estavam vazios, ao passo que, a precipitação no 
interior dos túbulos ocorreu somente quando a smear layer foi previamente removida com por ácidos.

\subsection{Estudos de Permeabilidade Dentinária in vitro}

A maior parte das evidências experimentais sobre os mecanismos da hiperestesia dentinária e do modo de ação de vários agentes na dentina deriva de estudos in vitro, em laboratório, e em menor proporção em animais, in vivo. Os experimentos in vitro, envolvem a preparação de espécimes em dentina coronária ou radicular que serão subseqüentemente avaliados, quantitativa ou qualitativamente, por uma variedade de técnicas, como: microscopias de várias naturezas e análise de imagens, identificação de componentes químicos na superfície dentinária por microanálise de raioss $X$, difração de raioss $X$ e infravermelho transformada de Fourier, além de ensaios de permeabilidade dentinária. Sena ${ }^{235}$, em 1990, enfatizou a importância dos testes laboratoriais em relação aos clínicos, principalmente pela dificuldade de manejo e seleção dos pacientes, diagnóstico diferencial e efeito placebo. E Gillam, Mordan e Newman ${ }^{72}$, em 1997, ressaltaram que todas as técnicas têm benefícios e limitações, portanto, os resultados devem ser sempre tratados com cautela, especialmente quando se refere à extrapolação clínica.

\subsubsection{Métodos Quantitativos de Permeabilidade Dentinária}

Pashley e seus colaboradores, baseados na fisiologia das membranas, relataram que existem três coeficientes independentes para mensurar quantitativamente a permeabilidade de uma membrana ou barreira: condutividade hidráulica, coeficiente de permeabilidade dos solutos, e coeficiente de reflexão dos solutos. A condutividade hidráulica quantifica a facilidade com que o fluido se desloca sob pressão hidrostática ou osmótica. 0 coeficiente de permeabilidade mensura a facilidade com que os solutos se difundem, sob gradientes de concentração química na ausência do deslocamento de corpo do fluido. E o coeficiente de reflexão define a relação entre a permeabilidade do soluto e solvente, isto é, 
proporciona uma medição quantitativa da habilidade de uma membrana discriminar entre a difusão da água e a difusão de solutos ${ }^{166,188,197}$.

O transporte de solutos através da dentina pode se dar por convecção ou filtração, difusão e iontoforese. O transporte convectivo ou por filtração é definido pelo deslocamento de substâncias dissolvidas ou suspensas através da filtração do fluido, sob uma baixa mas significante pressão hidrostática positiva do tecido pulpar, ou sob pressão osmótica negativa de soluções hipertônicas da cavidade oral. As variáveis mais importantes que influenciam o transporte convectivo, isto é, o movimento de corpo do fluido através da dentina são consideradas na equação de Pouesille-Hagen. No transporte difusivo, o fluxo do soluto é alto para substâncias de alto coeficiente de difusão, ampla área de superfície e alta concentração, e vice-versa. Há uma dissipação da concentração do soluto ao longo do transporte. As variáveis mais importantes que regulam o transporte difusivo através da dentina são resumidas na segunda lei de difusão de Fick. E, ainda, há o transporte de solutos através da dentina pela iontoforese, que induz o fluxo de íons por meio de um circuito elétrico ${ }^{166}$.

Pashley $^{175}$, em 1990, a partir de discussões prévias, adiantou que as medições da permeabilidade dentinária por difusão, utilizando traçadores radioativos ou não, que apesar de eficientes, consomem muito tempo, tanto quando realizadas in vitro quanto in vivo. Portanto, a condutividade hidráulica é o método mais conveniente para a medição da permeabilidade dentinária, direta ou indiretamente. O método de medição indireta, considera que na câmara pulpar há uma proporcionalidade entre volume e pressão, e que para cada modificação no volume há uma modificação na pressão dentro de um determinado período de tempo, proporcional ao movimento do fluido através da dentina. Este método, apesar de ser o mais sensível para a medição do movimento do fluido, tem a desvantagem de ser muito demorado e sensível às mudanças de temperatura ou pressão. 


\subsubsection{Câmara para medição da permeabilidade dentinária}

Uma ilimitada linha de pesquisa abriu-se, em 1974, quando Outhwaite, McKenzie e Pashley $^{157}$ planejaram uma câmara para estudar a permeabilidade dentinária de dentes extraídos por qualquer dos três métodos. A câmara desmontável dividida em duas porções foi projetada, de forma que a porção inferior aparafusa-se dentro da porção superior. Entre o reservatório superior e a porção inferior da câmara, estão a arruela plástica e o anel de silicone, assim como o disco de dentina a ser estudado. O volume do reservatório superior e o seu selamento com a superfície do dente foi determinado através do diâmetro e da profundidade do orifício na porção superior da câmara e da arruela plástica, e também do diâmetro do anel de silicone. Muitas variações no desenho da câmara como a adição de tubos laterais e anéis de silicone têm sido utilizadas para aplicações específicas. A câmara, na realidade, tanto pode ser o aparato desmontável contendo o disco de dentina ou pode ser utilizado um segmento coronário fixado numa plataforma de acrílico.

O índice do movimento do fluido através da dentina, geralmente do lado pulpar em direção a superfície, é medido pelo progresso de uma pequena bolha de ar no interior de um capilar, sobre uma escala milimetrada. Dependendo do tamanho do capilar, $1 \mu \mathrm{m}$ de deslocamento da bolha equivale a um volume $0,38 \mu$, num capilar de $25 \mu \mathrm{l}$. Há necessidade também de um tubo de polietileno e uma micro-seringa para ajustar a posição da bolha de ar no capilar, um cronômetro e, se for o caso, um reservatório pressurizado. A câmara de medição permite a padronização de variáveis importantes como área de superfície para a filtração ou difusão ${ }^{166}$.

\subsubsection{Cálculos de condutividade hidráulica (Lp)}

A condutividade hidráulica é o recíproco da resistência hidráulica, ou seja, refere-se à facilidade com que o fluido se movimenta através dos túbulos dentinários. Segundo descrito por Reeder et al. $^{217}$, em 1978, como os capilares de vidro têm diâmetro constante, 
dividindo-se o volume do capilar por seu comprimento, tem-se uma proporcionalidade constante capaz de converter o deslocamento linear em volume linear. Estes cálculos são expressos em termos de condutividade hidráulica (Lp), em função da espessura do disco de dentina, e obtidos empregando-se a equação:

$$
L p=\frac{Q}{P(S A)}
$$

onde, $\mathrm{Lp}$ é a condutividade hidráulica da dentina em $\mu \mathrm{cm}^{-2} \min ^{-1} \mathrm{~cm} \mathrm{H}_{2} \mathrm{O}^{-1}$, Q é o índice de filtração em $\mu \mathrm{min}^{-1}$, SA traduz a área de superfície em $\mathrm{cm}^{2}$ e $\mathrm{P}$, a pressão hidrostática através da dentina em $\mathrm{cm} \mathrm{H}_{2} \mathrm{O}$.

O índice de filtração de fluido ${ }^{166}, Q$, é expresso pela equação de Poiseuille-Hagen:

$$
\mathrm{Q}=\frac{\Pi \Delta \mathrm{P} \mathrm{r}^{4} \mathrm{~N}}{8 \eta \mathrm{L}}
$$

onde, $\Delta \mathrm{P}=$ pressão aplicada, hidrostática ou osmótica; $\mathrm{r}^{4}=$ raio do túbulo, isto é, dependente da smear layer; $\mathrm{N}=$ densidade do túbulo, dependente da profundidade; $\eta=$ viscosidade do fluido, dependente da temperatura e $L=$ comprimento do túbulo, dependente da espessura remanescente da dentina.

\subsubsection{Espécimes}

Conforme declararam Pashley et al. ${ }^{167}$, em 1981, a validade dos dados coletados in vitro está aberta a numerosos criticismos. Entretanto, é mais conveniente estudar a permeabilidade dentinária in vitro porque, exceto a variabilidade inerente à dentina, outras importantes variáveis como a área de superfície, espessura, e algumas características da superfície dentinária podem ser mais facilmente controladas. Também considera-se que os dentes recém-extraídos não contêm processos odontoblásticos nem fluxo sangüíneo proveniente da polpa, presentes na dentina estudada in vivo, e que podem alterar a 
permeabilidade $^{72}$. Por exemplo, a presença ou a ausência da smear layer, e a penetração de ácidos, enzimas e materiais exógenos para o interior dos túbulos dentinários in vitro parece ser maior do que in vivo ${ }^{269}$. Os experimentos podem também apresentar uma miscelânea de resultados quando são conduzidos in vitro com a dentina seca e condicionada, em oposição com a dentina preenchida com fluido na extremidade dos túbulos, que provavelmente simula o estado in vivo ${ }^{56}$.

Os espécimes dentinários destinados aos ensaios in vitro de condutividade hidráulica podem estar na forma de discos ou de segmentos coronários, sendo que os discos de dentina têm sido empregados por muitos pesquisadores $3,4,36,81,104,124,134,135,146,156,161,168,174,181,183$ $183,184,186,187,189,191,194,196,217$, que consideram ser o modelo in vitro mais representativo da condição in vivo.

Os discos de dentina, segundo Mordan, Barber e Gillam ${ }^{146}$ e, Gillam, Mordan e Newman ${ }^{72}$, em 1997, apesar das aparentes limitações, é reconhecidamente um sistema adequado para experimentar, in vitro, o efeito dos agentes anti-hiperestésicos na deposição superficial e na oclusão tubular, assim como os efeitos desses agentes no deslocamento do fluido através da dentina. A espessura uniforme, passível de ser reduzida por desgaste e a área de superfície, regulada pelo uso de pares de anéis de borracha da câmara de medição ou de depressões cônicas de diferentes tamanhos, são características que elegem o disco de dentina como um modelo reprodutível ${ }^{166}$.

Nos discos de dentina, apesar de serem reprodutíveis, a caracterização da dentina após os tratamentos pode ser confundida por diversos fatores, como a idade, a condição e a fonte do espécime dentinário, a densidade, diâmetro, direção e orientação transversal ou longitudinal dos túbulos, a presença ou ausência de dentina peritubular hipermineralizada, as variações da ramificação tubular, assim como os tipos e localizações dessas ramificações, o tamanho dos sulcos formados após o corte, e a presença ou a ausência da smear layer ${ }^{140,146}$. 
Os segmentos coronários também foram utilizados por diversos pesquisadores $73,75,76,131,161,171,179,80,186,198,200,213,239,253,286$ e podem ser empregados para experimentos de diferentes propostas além da permeabilidade dentinária, como estudos sobre adesão ${ }^{171,201} \mathrm{e}$

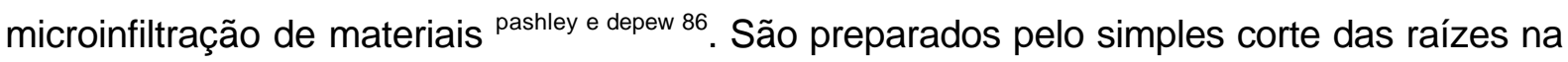
junção amelocementária, seguido da cuidadosa remoção do tecido pulpar e limpeza da câmara com soluções de cloreto de sódio ou EDTA. Conforme o objetivo do experimento, são preparadas nos segmentos coronários, cavidades, restaurações ou apenas uma superfície plana pela remoção do esmalte oclusal. Os segmentos são montados em uma placa de plexiglass, conectada a um tubo metálico que permite o preenchimento da câmara pulpar com uma solução, simulando a condição in vivo de hidratação da dentina. O conjunto é conectado ao sistema de capilares de polietileno que permite a simulação da pressão do tecido pulpar de duas maneiras: elevando-se o reservatório de líquido a uma altura predeterminada acima da câmara pulpar, obtendo-se assim, uma pressão correspondente, ou, e mais usualmente, se conecta o segmento coronário a um sistema pressurizado de fluido. De qualquer maneira, a medição do movimento do fluido por minuto é feita através de um capilar interposto entre o reservatório de líquido e o segmento coronário ${ }^{166}$.

Observações preliminares das características quantitativas da permeabilidade em dentes humanos extraídos demonstraram a complexidade da geometria de difusão de cavidades oclusais de segmentos coronários. A área total de superfície dentinária quando as cavidades são utilizadas é quase impossível de ser quantificada e mantida constante em função da variabilidade da espessura de esmalte e da irregularidade do contorno da junção amelodentinária. O mesmo ocorre quando são superfícies planas resultantes da simples remoção do esmalte oclusal do segmento dentinário, apesar de Pashley et al. ${ }^{161}$, em 1987, ter definido a área fotograficamente. E, ainda, apesar do assoalho cavitário e da superfície poderem ser éitos planos, as variações biológicas da morfologia do corno e da câmara pulpar fazem a espessura dentinária entre a cavidade ou a superfície e o teto da câmara 
ficar altamente variável. Como os cálculos de permeabilidade requerem um conhecimento preciso tanto da área de superfície quanto da espessura dentinária, o uso especialmente de cavidades é evitado. Ao invés, vários autores como Outhwaite, Livingston e Pashley ${ }^{156}$, em 1976, preferiram a utilização de discos de dimensões conhecidas.

A permeabilidade dentinária quantitativa em segmentos coronários é heterogênea, pois a maior permeabilidade está acima dos cornos pulpares, e a menor, no centro. Quando as mesmas medições são feitas em discos de dentina, a permeabilidade permanece heterogênea, mesmo os discos tendo espessura uniforme e nenhuma evidência de cornos pulpares na superfície pulpar. A espessura da dentina em segmentos coronários, é menor acima dos cornos pulpares e maior no centro, isto é, menor nas áreas mais permeáveis. A espessura dentinária esta incluída entre os importantes determinantes da difusão e filtração. Segundo Reeder et al. ${ }^{217}$, em 1978, quanto mais espessa for a dentina, maior é a dissipação do soluto na difusão. Também afirmaram que a dentina mais espessa tem maior resistência ao movimento do fluido do que a dentina menos espessa.

As propriedades de permeabilidade da dentina radicular também podem ser analisadas na forma de discos de dentina cortada longitudinalmente ou de segmentos radiculares $^{166}$. Fogel, Marshall e Pashley ${ }^{62}$, em 1988, demostraram que quando comparada à dentina coronária, a dentina radicular é menos permeável por unidade de área e espessura. E a dentina mais periférica é muito menos permeável do que a interna.

Muitas metodologias têm falhado em promover um adequado procedimento de controle que eliminasse problemas relacionados às modificações morfológicas, artefatos produzidos pelo procedimento de corte, ou por barreiras artificiais. Há variações na aparência da superfície de dentina, não apenas nos túbulos de um disco para o outro, mas também ao longo da superfície de um mesmo disco, pois, apesar dos túbulos serem de tamanho similar, são orientados para vários planos, obliquamente e paralelamente à superfície, apresentando diferentes seções transversais. Os tratamentos também são 
afetados pela seção transversal dos túbulos na superfície, pois, os túbulos grandes, redondos e verticais, são condicionados mais proporcionalmente do que os pequenos, ovais e horizontais ${ }^{146}$.

Do ponto de vista morfológico, a periferia do disco de dentina não deve ser utilizada para os estudos de permeabilidade. Os túbulos acima dos cornos pulpares têm um diâmetro maior do que os da periferia e são orientados perpendicularmente à superfície do disco, ou seja, a permeabilidade da dentina coronária œlusal é maior acima dos cornos pulpares e, portanto, oferece uma melhor superfície para teste ${ }^{146}$. Na região central, a permeabilidade mais baixa da dentina pode ser devido aos poucos túbulos por unidade de área de superfície do que acima dos cornos pulpares, além de ter diâmetros menores. A orientação dos túbulos é obviamente diferente em várias regiões, pois mesmo que os discos dentinários tenham uma espessura uniforme, nem todos os túbulos têm o mesmo comprimento, e os túbulos no centro podem ser mais tortuosos do que aqueles acima dos cornos pulpares, produzindo maior permeabilidade no centro do que na periferia ${ }^{161}$.

As indicações qualitativas da permeabilidade regional da dentina foram confirmadas quando os discos foram posicionados no aparato para as medições quantitativas da condutividade hidráulica. Pashley et al. ${ }^{161}$, em 1987, concluíram que as medições no centro do disco geralmente superestimam a Lp devido à centralização do anel de borracha coincidir parcialmente com as áreas dos cornos pulpares. Portanto, as investigações que medem a permeabilidade dentinária devem utilizar a maior área de superfície possível para permitir uma média das diferenças regionais da dentina.

Nos estudos em microscopia eletrônica de varredura, um bom controle da aparência dos túbulos dentinários, seria o exame exatamente da mesma área antes e após o experimento. Porém, isto não é viável pois a preparação necessária para análise, em várias metodologias, modifica a superfície e invalida qualquer teste futuro. Entretanto, uma boa correlação topográfica pode ser observada se áreas estudadas do disco de dentina 
estiverem suficientemente próximas. Um ótimo controle seria observar duas áreas adjacentes de um mesmo disco de dentina, uma tratada e outra não tratada ${ }^{146}$.

\subsubsection{Seleção dos dentes, armazenamento e tempo pós-extração}

Pashley, Livingston e Greenhill ${ }^{186}$, em 1978, concordaram que há uma grande variação na permeabilidade de dente para dente e de uma região do dente para outra. Goodis, Marshall e White ${ }^{76}$, em 1991, encontraram similarmente a mesma ampla variabilidade que atribuíram, em parte, à utilização terceiros molares tanto irrompidos como não irrompidos. Segundo estes autores, esta variabilidade pode ser controlada utilizando apenas terceiros molares não irrompidos de adolescentes, que teriam quantidade mínima de dentina secundária.

Os tempos de armazenamento dos dentes a serem experimentados variam amplamente, dentro de 30 dias após a extração ${ }^{75,131,156,169,180,201,217,239,286}, 1$ a 60 dias $^{191}$, acima de 21 dias $^{181}$, alguns meses ${ }^{200}$, e outros não determinam qualquer período de tempo para o armazenamento $^{62}$. O tempo pós-extração, na opinião de Outhwaite, Livingston e Pashley ${ }^{156}$, em 1976, parece ter uma mínima influência na permeabilidade dentinária mensurada in vitro. Explicaram, em parte, citando as informações de Brännström e Garberoglio $^{27}$, e de Tsatsas e Frank ${ }^{266}$, em 1972, de que os túbulos dentinários apenas contêm processos odontoblásticos próximos à polpa e que um grande número de túbulos vazios foi encontrado próximo ao esmalte. Portanto, já que a maior parte da dentina utilizada é da região que pode estar sem processos odontoblásticos, acreditam na ausência do efeito do tempo pós-extração na permeabilidade dentinária. Reforçando estas informações, o trabalho de Pashley, Livingston e Greenhill ${ }^{186}$, em 1978, indicou que a presença de processos odontoblásticos nos túbulos dentinários é responsável apenas por 7,48\% da redução da filtração. Já para Goodis, Marshall e White ${ }^{76}$, em 1991, e Goodis et al. ${ }^{73}$, em 
1993, o tempo de armazenamento prolongado dos dentes reduz a permeabilidade dentinária.

A solução de armazenamento também é uma variável bastante freqüente. De acordo com Goodis, Marshall e White ${ }^{76}$, em 1991, e Goodis et al. ${ }^{73}$, em 1993, o tipo de solução utilizada pode interferir na permeabilidade dentinária. As várias soluções que têm sido utilizadas, incluem: a solução fosfatada e tamponada de Krebs-Ringer ${ }^{81,156,185,187,217}$, solução salina fosfatada e tamponada com azido de sódio ${ }^{61,180,183,191,255}$, solução salina normal ou isotônica com azido de sódio ${ }^{200,213}$. Também, formalina ${ }^{46}$, solução de timol $^{131,198,201,286}$ e água destilada ${ }^{4}$.

Especialmente no caso de armazenamento com solução salina, pode-se observar uma diminuição da permeabilidade dentinária com o tempo devido à precipitação de sais no interior dos túbulos ${ }^{73,76,194}$ e/ou também, pela dissolução e redeposição tanto de componentes orgânicos como inorgânicos da dentina no lúmen tubular. Os casos de aumento da permeabilidade podem ser creditados ao efeito da eliminação pela lavagem dos componentes minerais dos túbulos pelas soluções de armazenamento. Com relação às soluções com timol, e com o azido de sódio, sabe-se que impedem o crescimento bacteriano, e é largamente admitido que não exercem efeito tanto no conteúdo orgânico como inorgânico da dentina ${ }^{76}$.

E ainda, Camps et al. $^{36}$, em 1994, e Camps et al.. ${ }^{37}$, em 1997, afirmam que a criopreservação não modifica a permeabilidade dentinária. E Pashley, Tao e Pashley ${ }^{195}$, em 1993, reportaram que a esterilização em autoclave ou com óxido de etileno podem produzir modificações bioquímicas na dentina que não são mensuráveis nos testes de permeabilidade e adesão dentinária. Aparentemente, nem a baixa e nem a alta temperatura alteram as propriedades funcionais da dentina, desde que o dente esteja intacto e a dentina mineralizada. Ao contrário, o armazenamento refrigerado com anti-sépticos modifica a permeabilidade dentinária pela precipitação intratubular de componentes minerais ${ }^{81}$, ou de 
componentes orgânicos como os processos odontoblásticos, ou fibras colágenas intratubulares. A grande maioria dos estudos refere-se à temperatura de $4^{\circ} \mathrm{C}$ para $\mathrm{o}$ armazenamento $^{73,76}$.

\subsubsection{Obtenção dos discos de dentina}

O método para a obtenção dos discos de dentina, a partir de terceiros molares humanos extraídos, foi descrito primeiramente por Outhwaite, Livingston e Pashley ${ }^{156}$, em 1976. Preconizaram a remoção de todo o esmalte da superfície oclusal da coroa, utilizando broca carbide 556 em alta velocidade e sob refrigeração, mantendo um plano paralelo ao plano oclusal do dente. A presença de resíduos de esmalte, decorrentes da extensão pulpar das cicatrículas e fissuras, examinada sob luz refletida com seis vezes de magnificação, era eliminada por intermédio de lixas abrasivas. A porção radicular e a porção remanescente da coroa, foram seccionadas da mesma forma, com brocas em alta velocidade e sob refrigeração, paralelamente ao plano preestabelecido, na altura do teto da câmara pulpar. Os discos produzidos desta maneira eram geralmente não mais espessos do que 1,6 mm e usualmente com 1,0 mm de espessura, após serem tomados os cuidados para reduzi-los ao ponto onde nenhum sinal de cornos pulpares remanescer. Diversos autores seccionaram os dentes para obtenção dos discos de dentina, da maneira descrita, com brocas $^{36,81,134,156,185,217}$. Outros, ao invés de brocas, utilizaram discos de diamante adaptados a uma máquina de corte específica para adquirir espécimes com as mesmas características $37,135,161,174,181,189,190,191,194,196$

A afirmação de Brännström e Garberoglio ${ }^{27}$, em 1972, de que o diâmetro dos túbulos dentinários decrescem progressivamente da polpa para o esmalte, e os dados de Outhwaite, Livingston e Pashley ${ }^{156}$, em 1976, suportam a idéia de que a metade pulpar dos discos de dentina é mais permeável do que a metade oclusal, mesmo quando ambas as espessuras são semelhantes. Isto pode ser devido ao maior número de túbulos dentinários 
por unidade de área superficial na metade pulpar ou que o maior diâmetro de cada túbulo está no lado pulpar, ou ambos. A mudança do número de túbulos no disco de dentina é inteiramente dependente da direção na qual a espessura dentinária é reduzida, considerando uma área de superfície constante.

Em outras palavras, conforme a espessura dentinária é reduzida do lado pulpar do disco, a área de superfície de dentina tubular diminui devido ao aumento da matriz intertubular calcificada, além da diminuição da tortuosidade dos túbulos. Conforme à redução da espessura dentinária do lado do esmalte resulta em aumento da permeabilidade, pois a área de superfície de dentina tubular aumenta devido a redução relativa da quantidade de dentina intertubular, ou seja, há maior número de túbulos por unidade de área conforme a maior proximidade da câmara pulpar.

Reduções na espessura dentinária do lado do esmalte promovem um aumento de 6 a 8 vezes na permeabilidade, enfatizando uma das mais importantes variáveis estudadas. Portanto, os dados mostram a necessidade de definir exatamente o nível da secção da dentina coronária porque as variações relacionando a permeabilidade dentinária e a área de superfície podem ser diferentes dependendo da distância da câmara pulpar ${ }^{156}$.

\subsubsection{Permeabilidade mínima - smear layer}

Para facilitar a interpretação dos dados referentes ao potencial de ação dos agentes anti-hiperestésicos e permitir a utilização de cada espécime como seu próprio controle, é comum a determinação da mínima e da máxima permeabilidade dos discos de dentina.

In vivo, a smear layer provavelmente resulta do desgaste, escovação, aglomerações de proteínas, placa, etc. ${ }^{161,160}$. In vitro, no espécime de dentina, esta camada é meramente um artefato do corte e varia dependendo da superfície que está sendo cortada, das irregularidades da lâmina de corte, da pressão aplicada e da refrigeração ${ }^{58}$. Uma vez formada, não é uma estrutura uniforme e sua remoção não deixa uma superfície 
homogênea. Os sulcos vistos ao longo da superfície são quase certamente formados pela lâmina de corte e, devido ao acúmulo irregular da smear layer nestes sulcos, pode haver um tratamento desigual da superfície dentinária.

Apesar da smear layer poder ser facilmente removida por meios químicos ${ }^{29}$, o mesmo não ocorre mecanicamente ${ }^{166,171}$. A espessura da smear layer calculada a partir do conteúdo de cálcio dos resíduos removidos por ultra-som e filtrados é menor quando comparada àquela medida empregando-se a microscopia eletrônica de varredura de espécimes de dentina fraturada. Isto é devido à incompleta remoção dos resíduos pelo ultrasom. Por outro lado, a análise química das soluções ácidas ou do EDTA utilizadas para a remoção da smear layer, irá superestimar a espessura da smear layer porque os agentes químicos não param na junção entre a smear layer e a matriz dentinária. Invariavelmente, removem não só a smear layer, mas uma boa quantidade da matriz dentinária mineral subjacente ${ }^{166}$.

Dependendo de como a dentina é cortada, a espessura da smear layer varia grandemente, aproximadamente de 1 a $5 \mu \mathrm{m}$. Genericamente, o corte sem refrigeração de água gera uma camada de resíduos mais fina, assim como, as brocas diamantadas tendem a produzir uma smear layer mais fina do que as brocas carbide ${ }^{33}$. A smear layer mais espessa, em torno de 10 a $15 \mu \mathrm{m}$, é a produzida in vitro pelo disco de diamante utilizado para a obtenção dos espécimes dentinários ${ }^{190}$.

Vários autores acreditam que o método mais adequado de simular in vitro a condição in vivo da smear layer seria utilizando uma lixa abrasiva de granulação 320, adaptada a uma máquina para desgaste que permita um controle preciso, na qual o lixamento do espécime é feito durante cinco segundos a uma rotação de 108 rpm, sob 500 gramas de força vertical e em água corrente ${ }^{171,179,189,215,239}$. Pashley ${ }^{166}$, em 1990, observou que a granulação da lixa tem uma profunda influência no quanto a smear layer resultante reduz a permeabilidade 
dentinária. Isto é, quanto mais fina for a lixa, maiores são as reduções na nos valores da permeabilidade.

Simpson $^{239}$, em 1992, relatou que a lixa de granulação 320 produz uma smear layer mais espessa que mais fielmente reproduz uma condição clínica. As micrografias das superfícies dentinárias tratadas com esta lixa mostram linhas de desgaste formadas pelas partículas abrasivas. Para Pashley et al. ${ }^{160,171}$, em 1988 e 1989, a smear layer produzida pela lixa de granulação 320 tem aparência tipicamente amorfa quando examinada em baixa magnificação, apresentando um tamanho de partículas muito pequeno. Entretanto, em alta magnificação, a subestrutura granular pode ser vista, especialmente acima dos lumens dos túbulos dentinários. Os glóbulos da smear layer, produzidos por esta lixa, têm a aparência globular fina, com diâmetro aproximado de 0,05 a 0,1 $\mu \mathrm{m}$, apesar de estarem sempre agregados em partículas maiores, parecendo uma verdadeira smear layer. A aparência da smear layer simulada com lixa de granulação 600 é de glóbulos extremamente unidos formando subunidades globulares com diâmetro de aproximadamente $0,1 \mu \mathrm{m}$. Os autores sugerem que as partículas da smear layer são compostas de uma subestrutura globular que representa as menores dimensões das fibras colágenas mineralizadas.

\subsubsection{Permeabilidade máxima - limpeza com ácido}

A presença da smear layer proporciona grande quantidade de íons cálcio e fosfato disponíveis para reagir, em contrapartida, sua remoção com agentes químicos diminui o número de íons que podem interagir, diminuindo o número de precipitados. Então, dependendo do pré-tratamento da smear layer, a reatividade da superfície dentinária será diferente e também a quantidade de íons cálcio e fosfato disponíveis para participar de reações químicas ${ }^{56}$. Entretanto, Yamamoto et al. $^{277}$, em 1996, ressaltaram que se a smear layer não for removida com condicionamento ácido previamente ao tratamento, quase todos os cristais estarão localizados apenas na superfície dentinária, e os túbulos estarão ainda 
abertos, indicando que a condição da dentina exposta pode ser crítica quando se estuda o tratamento da dentina hiperestésica.

Para simular a dentina hiperestésica, a smear layer pode ser removida utilizando vários agentes como o EDTA a $0,5 \mathrm{M}$, ácido cítrico a $50 \%$ ou a $6 \%$ e ultra-som ${ }^{1,112,116,166,248}$. Dos condicionadores ácidos utilizados clinicamente, o EDTA é o único que exerce o efeito de desmineralizante através de quelantes cátions divalentes em $\mathrm{pH}$ neutro, enquanto que o ácido fosfórico atua por meio de pH baixo e dissolve ou erosiona a superfície mineralizada. O ácido cítrico funciona pela combinação dos 2 mecanismos ${ }^{15}$.

Segundo Brännström e Johnson ${ }^{29}$, em 1974, embora os agentes desmineralizantes, incluindo o tratamento com ácido cítrico a 50\% durante um minuto, produzam uma superfície limpa, eles também desobstruem e ampliam demais a abertura dos túbulos dentinários obliterados pelos resíduos. Com a remoção de quase toda dentina peritubular, os túbulos ficaram afunilados e alargados, o diâmetro passou a medir de 3 a $5 \mu \mathrm{m}$ numa extensão de 10 a $20 \mu \mathrm{m}$, comparados a diâmetro normal de 1 a $2 \mu \mathrm{m}$. Já, Brännström, Nordenvall e Glantz ${ }^{33}$, em 1980, divulgaram que as soluções contendo EDTA possuem a capacidade de remover a smear layer amorfa de dentes humanos, in vivo, sem ampliar demais a abertura dos túbulos ou remover a dentina peritubular.

A fim de remover a smear layer presente na superfície dentinária e simular o padrão tubular da dentina hiperestésica in vivo, Cuenin et al. ${ }^{47}$, em 1991, verificaram o aumento no grau hiperestésico na metade dos pacientes após aplicarem EDTA a 0,5 M e pH 7,4 numa área selecionada de dentina exposta. A inabilidade de induzir a hiperestesia em todos os pacientes pela remoção da smear layer superficial pode ser devido à presença da oclusão intratubular, apesar da exposição dentinária. A microscopia eletrônica mostrou uma abertura tubular maior após o tratamento com EDTA e menor após o tratamento com oxalato de potássio, confirmando que quanto menor a abertura tubular, menor a hiperestesia dentinária. 
Dragolich et al. $^{56}$, em 1993, observaram maior número de túbulos dentinários abertos após o condicionamento da smear layer com ácido cítrico a 140\% em comparação com o ácido cítrico a $20 \%$ e o EDTA. Observaram também que a dentina com a smear layer intacta e a tratada com ultra-som exibiram maior número de cristais e maior variedade de formas cristalinas na superfície dentinária após o tratamento com oxalato férrico. Reforçando esses resultados, os trabalhos de Gillam, Mordan e Newman ${ }^{72}$, e Mordan, Barber e Gillam ${ }^{146}$, ambos em 1997, visualizaram microscopicamente que nas superfícies dentinárias tratadas com ultra-som e água destilada, permaneceram partículas de resíduos e, após o condicionamento com ácido cítrico a 6\%, a smear layer foi removida e os túbulos ficaram claramente visíveis e a dentina intertubular exposta.

Pashley, Michelich e $\mathrm{Kehl}^{190}$, em 1981, relataram que o condicionamento com ácido cítrico a $6 \%$ durante um minuto, remove praticamente toda a smear layer assim como a superfície dentinária peritubular dos túbulos, agora com diâmetros três a quatro vezes maiores do que o normal, confinado a uma profundidade de aproximadamente $10 \mu \mathrm{m}$ da superfície. Observaram, também que a permeabilidade dentinária atinge o valor máximo após 15 segundos de condicionamento.

Na experiência de Pashley et al. ${ }^{174}$, em 1978, a condutividade hidráulica aumentou 15 vezes após o condicionamento com ácido cítrico, noutro estudo 32 vezes ${ }^{217}$ e ainda, 43 vezes noutro $^{173}$. A remoção da smear layer aumenta a permeabilidade dentinária por difusão aproximadamente de cinco a seis vezes in vitro e, por filtração, o aumento fica elevado ao quadrado, ou seja, de 25 a 36 vezes. Estes dados foram obtidos após o preparo da smear layer com disco diamantado, e são relativamente mais altos do que os produzidos clinicamente com pontas diamantadas. Os valores de filtração com a smear layer antes do condicionamento ácido obtidos in vivo são cinco vezes maiores dos obtidos in vitro, porém os valores após o condicionamento são similares ${ }^{173}$. Há, portanto, uma relação inversa da permeabilidade inicial da dentina com a permeabilidade após o condicionamento ácido, 
sendo a magnitude da modificação do movimento do fluido através da dentina antes e depois do condicionamento ácido indicativa da espessura ou da densidade da smear layer.

O condicionamento da dentina com ácidos fracos e agentes quelantes como o EDTA, em adição ao aumento da permeabilidade dentinária devido à remoção da smear layer pela dissolução das partículas, revela as embocaduras dos túbulos dentinários subjacentes, mantendo os smear plugs e expondo as fibras colágenas ${ }^{15,33,167,168}$.

\subsubsection{Direção de filtração}

Os achados de Pashley, Livingston e Greenhill ${ }^{186}$, em 1978, mostraram que a resistência ao movimento do fluido através da dentina é dependente da presença ou ausência do tecido pulpar e dos resíduos superficiais, e do grau de oclusão intratubular. Porém, a resistência também é dependente da direção de filtração do fluido, pois o maior índice de filtração foi sempre obtido quando a filtração foi feita na direção do esmalte para a polpa.

Se for considerado que as diferenças direcionais na resistência são devido a leves mudanças na posição do corpo celular e/ou processos odontoblásticos em relação ao túbulo, então, a remoção do odontoblasto poderia abolir a resposta. Contudo, a reversão na direção de filtração, isto é, da polpa para o esmalte, antes da remoção do tecido pulpar produziu uma maior redução na filtração do que após a remoção da polpa. Mesmo que um número substancial de corpos celulares de odontoblastos for removido, seus processos protoplasmáticos provavelmente permanecerão dentro dos túbulos e podem se mover em resposta a mudanças direcionais na filtração. A reversão da direção de filtração após uma semana da extração produziu uma mudança menor no grau de filtração. Presumivelmente, os corpos celulares odontoblásticos e/ou processos protoplasmáticos sofreram autólise, desintegrando-se lentamente após uma semana de intervalo, diminuindo a resistência do fluido e eliminando o efeito direcional da resistência ${ }^{186}$. 
Como relatou Pashley et al. ${ }^{169}$, em 1996, apesar de não ter havido diferença nas medições da condutividade hidráulica in vitro quando a direção de filtração foi invertida, há diferença nas medições in vivo. A condutividade hidráulica medida na direção da polpa para o esmalte é maior do que a alcançada na direção oposta ${ }^{192,269}$. Estes resultados coincidem com os de Pashley, Livingston e Greenhill ${ }^{186}$, em 1978, em dentes recém-extraídos na primeira semana do experimento.

\subsubsection{Pressão pulpar e pressão hidrostática}

O dente é exposto a uma enorme variação de pressões, desde as forças mastigatórias de 1 a $10 \mathrm{~kg}$ que não são incomuns ${ }^{170}$. Quando o esmalte é removido por cárie, trauma, ou tratamento dentário, se torna teoricamente possível transformar $10 \mathrm{~kg}$ de força em pressão hidrostática. Se a pressão é a força por unidade de área, a pressão produzida por qualquer força depende da área de superfície sobre a qual é aplicada. A área de superfície difusional, na equação de Fick, depende do quadrado do raio, pois a área do túbulo é $\Pi r^{2}$. Então, a difusão é proporcional ao quadrado do raio do túbulo dentinário. Já, de acordo com a Lei de Poiseuille-Hagen, a filtração varia com a quarta potência do raio, ao invés do quadrado do raio como na difusão, e a força de direcionamento é o gradiente de pressão ao invés do gradiente de concentração ${ }^{181}$.

Os experimentos de Brännström, Johnson e Lindén ${ }^{30}$, em 1968, observaram que se a dor é devido ao movimento do fluido através da dentina e que uma pressão de 1 a 3 $\mathrm{kg} \mathrm{cm}^{-2}$ causa dor, então, esta pressão provoca o movimento do fluido. Esta é a pressão hidrostática, de 0,6 a 3 atms, que tende a mover o fluxo de fluido através da dentina em direção a polpa. Por outro lado, uma solução saturada devido à ingestão de um doce, por exemplo, cria uma pressão osmótica que pode mover o fluido na direção oposta, isto é, da polpa para a superfície. Estudos in vivo de Anderson, Matthews e Shellton ${ }^{8}$, em 1967, sugeriram que soluções bastante concentradas, de 2 a $8 \mathrm{M}$, são requeridas para provocar 
dor. A pressão osmótica teórica correspondente a estas soluções é enorme, entre 100 e 2500 atms. Entretanto, segundo Pashley e Whitford ${ }^{197}$, em 1980, a pressão osmótica efetiva é apenas uma pequena fração da pressão teórica, devido à discriminação da dentina entre a água e os solutos.

Maita et al. ${ }^{128}$, em 1991, calcularam uma pressão pulpar de $42 \mathrm{~cm} \mathrm{H}_{2} \mathrm{O}$ e justificam que não é estatisticamente diferente de $32,6 \mathrm{~cm} \mathrm{H} \mathrm{H}_{2} \mathrm{O}(24,1 \mathrm{~mm} \mathrm{Hg})$ encontrada por Pashley, Nelson e Pashley ${ }^{192}$, em 1981, ambos trabalharam in vivo, através da dentina intacta de dentes de cães. $\mathrm{O}$ resultado de $14,1 \mathrm{~cm} \mathrm{H}_{2} \mathrm{O}$ obtido por Ciucchi et al. ${ }^{42}$, em 1995, em dentes humanos, é similar a $15 \mathrm{~cm} \mathrm{H}_{2} \mathrm{O}(11 \mathrm{~mm} \mathrm{Hg})$, obtido por Vongsavan e Mattews ${ }^{269}$, em 1992, em gatos, utilizando técnicas semelhantes. Isto é, estimaram a pressão do tecido pulpar através da dentina intacta determinando a pressão exógena requerida para anular o fluxo dentinário. Estudando a permeabilidade dentinária de cães in vivo, Pashley et al. ${ }^{173}$, em 1983, concluíram que a pressão do tecido pulpar não varia o suficiente para causar grandes erros nos cálculos de Lp.

Estudando os fatores determinantes da condutividade hidráulica in vitro, Reeder et al. ${ }^{217}$, em 1978, demonstraram que a filtração através dos discos de dentina aumenta linearmente conforme o aumento gradual da pressão hidrostática, de 60 para 120 e para $240 \mathrm{~cm} \mathrm{H} \mathrm{H}_{2} \mathrm{O}$. E Camps et al. ${ }^{37}$, em 1997, também concordaram que a variação da pressão pode alterar os valores de condutividade hidráulica da dentina. Explicaram que as pressões mais altas de 53,3 KPa provocam o aumento da resistência intratubular pela compressão do conteúdo interno dos túbulos contra suas paredes, possivelmente subestimando os valores de filtração. In vivo, utilizando pressão fisiológica pulpar, os resultados são mais próximos da realidade, pois o conteúdo intratubular não é afetado e nem há alteração dos valores com o tempo de filtração. Ao recomendar a utilização de pressão e tempo de filtração reduzidos, os autores alertam para a necessidade da utilização de um dispositivo de alta precisão, que permita a medição de pequenos deslocamentos de fluido. 


\subsubsection{Estudos de Condutividade Hidráulica, in vitro.}

Os estudos de condutividade hidráulica utilizam-se da filtração para uma ampla variedade de propósitos, como a determinação de importantes aspectos da dentina, da smear layer, de células e do meio externo $37,75,85,108,131,134,135,161,180,186,190,191,193,194,196,200$, $209,213,215,217,246,253,255$. Alguns desses estudos e outros que avaliaram o potencial de agentes, especialmente os oxalatos e fluoretos, no tratamento da hiperestesia dentinária através da filtração, ou seja, da redução do movimento do fluido no interior dos túbulos dentinários, serão apresentados a seguir, com suas variações metodológicas ${ }^{61,63,81,141,144,145,168,179,180,181,183,184,198,227,237,239,248,286}$.

Stevenson $^{246}$, em 1965, idealizou, observar microscopicamente a movimentação do fluido na dentina exposta como resultado da aplicação de uma pressão reduzida in vitro, e correlacionar o volume e a rapidez desta movimentação com a aspiração de odontoblastos para o interior dos túbulos. Uma câmara foi desenhada de maneira que permitisse que a superfície dentinária exposta da coroa fosse observada microscopicamente, enquanto era sujeita a reduções de pressão de 25 a 700 mm Hg abaixo da atmosfera. Os pré-molares e terceiros molares tiveram a dentina da superfície oclusal exposta por fratura ou por corte com disco de carborundo. Quando a dentina era exposta por fratura, com a redução da pressão, o fluido em forma de gotículas aglutinando-se em poças, pôde ser visto exsudando dos túbulos. A dentina exposta por desgaste teve sua exsudação reduzida tanto em quantidade quanto em proporção. As seções mostraram que a aspiração odontoblástica na dentina exposta por fratura parecia estar relacionada com o movimento do fluido para o exterior dos túbulos, mas não ocorreu caso algum em que o movimento do fluido foi abundante e veloz. A aspiração de odontoblastos atribuída ao movimento do fluido pela redução de pressão não ocorreu em dentina exposta por desgaste.

Johnson, Olgart e Brännström ${ }^{108}$, em 1973, mediram o fluxo centrífugo dos fluidos nos túbulos de dentinas expostas por fratura em dentes com gradiente de pressão fisiológica 
e, verificaram quando tal fluxo pode produzir aspiração dos odontoblastos para o interior dos túbulos. O experimento in vitro, utilizou pré-molares, alguns tiveram a cúspide vestibular removida por fratura, noutros a dentina foi exposta por desgaste. Os dentes foram adaptados a um aparato de medição com a raiz conectada a um tubo capilar e a coroa voltada para baixo, conectada a um tubo de vidro em forma de $\mathrm{J}$ preenchido com soro eqüino, de maneira que o gradiente de pressão da polpa para a dentina exposta fosse eliminado. As medições foram feitas a cada 24 horas, durante cinco a oito dias, sem a presença de pressão e com pressão hidrostática de $30 \mathrm{~mm} \mathrm{Hg}$ no sentido polpa-dentina exposta, de acordo com a diminuição da coluna de líquido no tubo capilar. Outros dentes com a cúspide fraturada da mesma maneira, foram expostos a diferentes variações de pressão, para analisar a aspiração dos odontoblastos para o interior dos túbulos por meio de cortes seriados. Em todos os dentes em que a superfície dentinária foi obtida por fratura, houve uma movimentação centrífuga do fluido nos túbulos, mas nenhum tipo de movimentação foi observado nos dentes em que a superfície da dentina foi desgastada. $\mathrm{Na}$ região central da superfície dentinária exposta por fratura, os túbulos apresentavam-se fraturados, enquanto que na periferia, correspondente a um quarto e a um terço da superfície dentinária exposta, os túbulos estavam desgastados. Na dentina fraturada, com túbulos visivelmente abertos, a média de movimentação foi superior a $0,6 \mathrm{ul} / \mathrm{mm}^{2}$, isto implica que um túbulo aberto pode ser seco cerca de dez vezes ao dia. O exame histológico dos dentes sugeriu que a redução na camada odontoblástica por aspiração das células para o interior dos túbulos dentinários em dentina exposta é o resultado da movimentação centrífuga do fluido nos túbulos produzido por um gradiente de pressão fisiológica.

Pashley, Livingston e Greenhill ${ }^{186}$, em 1978, esclareceram que a dentina, mecanicamente, oferece várias resistências à movimentação do fluido: resistência superficial, devido à presença de resíduos ocluindo os túbulos dentinários; resistência intratubular, em função da presença de nódulos mineralizados e túbulos tortuosos; e 
resistência pulpar, devido à presença de odontoblastos dentro dos túbulos. Assim, a intenção deste estudo foi estimar a contribuição de cada um desses fatores na resistência à movimentação do fluido imposta pela dentina. Obtiveram segmentos coronários preparados a partir de terceiros molares humanos inclusos, de maneira que a menor espessura dentinária fosse de 1,33 $\mathrm{mm}$. Os segmentos de coroa foram adaptados entre os anéis de borracha da câmara de filtração (Figura 5), fornecendo uma área de dentina exposta oclusal de $0,178 \mathrm{~cm}^{2}$. Os espécimes foram submetidos à filtração em quatro situações: nos segmentos de coroas intactos, após a remoção da polpa, após o condicionamento com ácido cítrico a $50 \%$ por dois minutos e após a manutenção dos espécimes por sete dias em solução fosfatada de Krebs-Ringer. Cada espécime foi também submetido a variações na direção de aplicação da pressão hidrostática, esmalte-polpa e polpa-esmalte. A resistência de superfície foi responsável por $86,44 \%$ da resistência total, a resistência do tecido pulpar por $7,48 \%$ e a resistência intra-tubular foi calculada pela diferença entre a resistência total e as obtidas no experimento. A resistência à movimentação do fluido variou com a direção de aplicação da pressão, sendo menor quando aplicada na direção do esmalte para a polpa.

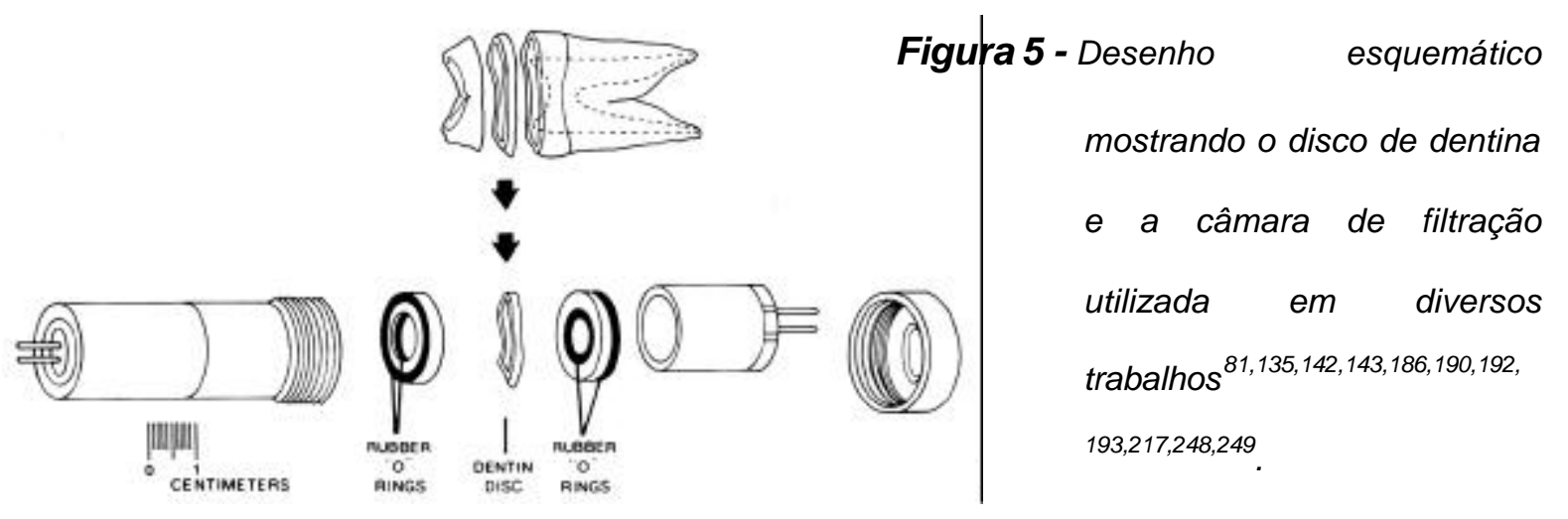

O estudo Reeder et al. $^{217}$, em 1978, visou determinar a influência da pressão hidrostática, área de superfície e espessura dentinária na condutividade hidráulica. As avaliações quantitativas foram realizadas através de discos dentinários, obtidos de terceiros 
molares humanos, e adaptados entre os anéis de borracha da câmara de medição da condutividade hidráulica (Figura 5). A pressão hidrostática variou de 60 a 120 e a $240 \mathrm{~cm} \mathrm{H} \mathrm{H}_{2} \mathrm{O}$, no sentido esmalte-polpa, conforme a altura do reservatório da solução fosfatada de krebs-Ringer acima do disco. A filtração foi medida em três períodos consecutivos de 30 minutos, antes e após o condicionamento dos discos com ácido cítrico $50 \%$ por dois minutos. Para cada mudança de espessura do disco, de 0,99 a 0,86 , a 0,74 e a 0,61 mm obtida pelo lixamento no lado do esmalte, a área de superfície dentinária testada

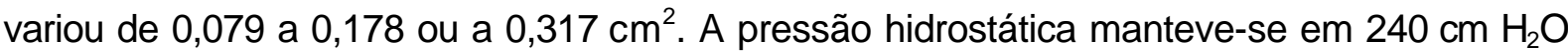
quando foram executadas as variações de área e espessura. Os cálculos foram expressos em termos de condutividade hidráulica (Lp), aumentando de acordo com o aumento da área de superfície e/ou com a diminuição da espessura da dentina. Também aumentou linearmente conforme o aumento da pressão hidrostática e 32 vezes quando a dentina foi condicionada com ácido devido à remoção de resíduos superficiais que ocluíam os túbulos. Concluíram, portanto, que o padrão de oclusão dos túbulos dentinários, a área de superfície e a espessura da dentina variam dependentemente das condições experimentais.

Michelich, Pashley e Whitford ${ }^{135}$, em 1978, compararam anatômica e funcionalmente o diâmetro tubular de discos dentinários e discos de vidro, empregando os métodos de condutividade hidráulica e de microscopia eletrônica de varredura. Nos discos dentinários, as medições do diâmetro funcional foram determinadas antes e após sua imersão no ácido cítrico a 50 \% durante dois minutos. A solução fosfatada de Krebs-Ringer filtrou no sentido esmalte-polpa, através de uma área de $0,3167 \mathrm{~cm}^{2}$ de dentina exposta, utilizando-se do sistema de um sistema de filtração (Figura 5). A tensão superficial é a pressão hidrostática crítica necessária para romper a tensão superficial entre a água e uma solução imiscível com tensão superficial conhecida, posta no lado do esmalte da câmara, movimentando o fluido através do disco dentinário. Os valores do diâmetro funcional, tanto o obtido por filtração como por meio da tensão superficial, foram calculados empregando-se 
equações específicas. O diâmetro funcional dos discos de dentina variou de 5 a $40 \%$ do diâmetro anatômico, este último determinado através da microscopia eletrônica de varredura. Observaram que os túbulos contêm diâmetro irregular e resíduos oclusores que interferem na permeabilidade. Esta diferença ocorreu devido ao fato de que em microscopia eletrônica visualiza-se apenas a superfície enquanto que na técnica funcional mede-se o diâmetro no interior dos túbulos. Assim, segundo os autores, os dados obtidos por filtração refletem mais proximamente a média do diâmetro tubular funcional quando se considera a dinâmica do fluxo de fluido.

Pashley, Michelich e KehI ${ }^{190}$, em 1981, examinaram, em microscópio eletrônico de varredura, a remoção seqüencial da smear layer dentinária com ácido cítrico a $6 \%$ e relacionaram estes efeitos à permeabilidade dentinária. Após o condicionamento no lado pulpar dos discos com ácido cítrico $6 \%$ por um minuto e utilizando o dispositivo para o teste de condutividade hidráulica (Figura 5), a solução fosfatada de Krebs-Ringer foi filtrada do lado do esmalte para o lado pulpar dos discos através de $0,3167 \mathrm{~cm}^{2}$ de dentina exposta. Os discos foram posteriormente condicionados no lado do esmalte por 5, 15, 30, 45 e 60 segundos com ácido cítrico a 6\%, e o índice de filtração foi novamente determinado, assim como os cálculos de condutividade hidráulica (Lp). Observaram, que a permeabilidade dentinária aumenta rapidamente com o condicionamento ácido expondo as embocaduras dos túbulos em apenas cinco segundos, alcançando o valor máximo após 15 segundos de condicionamento. Microscopicamente, ressaltaram que o condicionamento durante apenas um minuto remove quase toda a smear layer assim como a superfície dentinária peritubular dos túbulos até $10 \mu \mathrm{m}$ de profundidade, produzindo embocaduras três a quatro vezes mais largas.

Greenhill e Pashley ${ }^{81}$, em 1981, avaliaram a habilidade de agentes utilizados clinicamente no tratamento da dentina hiperestésica, em diminuir o índice de filtração do fluido in vitro. Os discos de dentina, obtidos de terceiros molares humanos, após serem 
tratados œm ácido cítrico a 50\% por dois minutos, foram adaptados no dispositivo para medição da condutividade hidráulica (Figura 5). A solução tamponada foi filtrada (Lp) através de uma área de superfície dentinária de $0,178 \mathrm{~cm}^{2}$, sob pressão de $240 \mathrm{~cm} \mathrm{H}_{2} \mathrm{O}$. Dentre os agentes anti-hiperestésicos aplicados por dois minutos no lado oclusal dos discos, estavam variações de fluoretos e oxalatos. Os dados da filtração variaram de $0 \%$, para o nitrato de potássio e cloreto de cálcio, a $98,40 \%$, para o oxalato de potássio a $30 \%$. Os valores de $17,77 \% ; 7,67 \% ; 39 \%$ e $24,50 \%$, foram obtidos, respectivamente, para o fluoreto de sódio neutro a $2 \%$, fluoreto de sódio a $1,23 \%$ em ácido fosfórico a $0,1 \mathrm{M}$, fluoreto de sódio a 1,23\% em ácido fosfórico a $0,1 \mathrm{M}$ seguido de cloreto de cálcio a $2 \%$ e fluoreto de sódio a $2 \%$ em ácido fosfórico $0,1 \mathrm{M}$. Microscopicamente, os espécimes tratados por oxalato de dipotássio a $30 \%$, demonstraram um precipitado homogêneo e moderadamente denso cobrindo a superfície dentinária. Os cristais de tamanho regular e semelhante ao tamanho das aberturas tubulares condicionadas, apareceram freqüentemente ocluindo parcialmente os túbulos, apesar da penetração normalmente não ultrapassar a porção afunilada do túbulo. Também puderam ser vistas estruturas semelhantes a fios conectando o cristal de oxalato de cálcio às paredes dos túbulos. (Figura 6). Entretanto, não se observou uma boa correlação entre a quantidade de precipitado formado e o grau de redução de condutividade hidráulica (Lp). Este método quantitativo in vitro demonstrou a efetividade de muitos agentes, tendo o oxalato se mostrado como o mais efetivo.
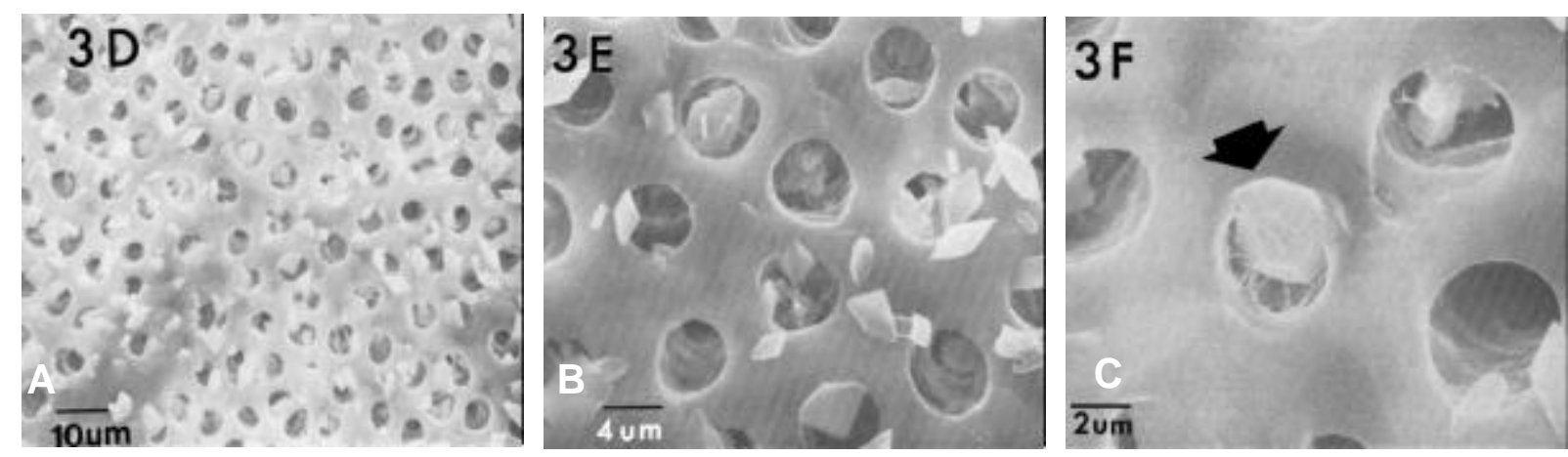

rıgura b - A - Uentına tratada com oxalato de potassıo a $30 \%$ revelando cristaıs de oxalato de calcıo que coincidem com o tamanho dos túbulos dentinários; B - Penetração dos cristais de oxalato de cálcio nos túbulos dentinários; C - Dentina tratada com oxalato mostrando fios de material conectando os cristais às paredes dos túbulos ${ }^{81}$. 
Pashley, Nelson e Williams ${ }^{193}$, em 1981, investigaram as mudanças produzidas pelas células vermelhas do sangue na condutividade hidráulica. Os discos de dentina, preparados e introduzidos na câmara de medição (Figura 5), foram expostos às células sangüíneas pelo lado pulpar, por onde foi aplicada a pressão hidrostática fisiológica de $25 \mathrm{~cm} \mathrm{H}_{2} \mathrm{O}$, determinada pela elevação do reservatório da solução tamponada acima da câmara. A solução foi filtrada antes e após o condicionamento com ácido cítrico a 6\% por dois minutos, assim como antes e após à exposição às células sangüíneas. A presença das células resultou numa queda de 17 vezes na condutividade hidráulica da dentina. A aparência histológica das células forçadas para o interior da dentina foi muito similar às encontradas na polpa de cães após preparos sem refrigeração in vivo. Concluíram que as células vermelhas do sangue são facilmente deformadas para o interior dos túbulos dentinários sob pressão hidrostática fisiológica, provocando uma grande redução da permeabilidade dentinária.

Pashley, Nelson e Kepler ${ }^{191}$, em 1982, experimentaram a possível influência dos constituintes da saliva, suspensões bacterianas e proteínas plasmáticas na permeabilidade dentinária, in vitro. Discos de dentina com $1 \mathrm{~mm}$ de espessura, obtidos de terceiros molares humanos, foram condicionados com ácido cítrico a $50 \%$ por dois minutos para assegurar que ambos os lados estavam livres de smear layer. Foram adaptados na câmara de medição da permeabilidade (Figura 5), situada $200 \mathrm{~cm}$ abaixo do reservatório da solução de salina tamponada. A área de superfície dentinária de $0,283 \mathrm{~cm}^{2}$ e a pressão de filtração de $200 \mathrm{~cm} \mathrm{H}$ O foram mantidas constantes. O plasma, o soro e os constituintes plasmáticos foram aplicados no lado pulpar do disco, por cinco minutos, antes de serem filtrados pela dentina durante 15 minutos. A saliva foi utilizada da mesma forma, porém aplicada no lado do esmalte. Os dados de filtração da solução salina (Lp), antes e depois do tratamento, indicaram que o plasma, soro e a saliva são capazes de reduzir imediatamente a permeabilidade dentinária. Frações individuais de proteína plasmática e muitos diferentes 
tipos de bactéria foram também efetivos na redução condutividade hidráulica. Estas observações podem corroborar o mecanismo de redução espontânea da hiperestesia dentinária defendida por clínicos após uma terapia periodontal.

O objetivo deste estudo de Pashley, Thompson e Steward ${ }^{196}$, em 1983, foi determinar, in vitro, a influência da temperatura na condutividade hidráulica. Os discos de dentina, obtidos a partir de terceiros molares humanos, foram estudados em duas seqüências e temperaturas, uma em graus positivos e outra, negativos: 10, 20, 30, 40 e $50^{\circ} \mathrm{C}$. Os discos de dentina tiveram o lado pulpar condicionado com ácido cítrico a $6 \%$ durante 2 minutos e foram adaptados na câmara modificada para a medição da condutividade hidráulica (Figura 7). Outra medição foi feita após a remoção da smear layer do lado oclusal dos discos de dentina. A filtração da água foi realizada do lado pulpar para o lado oclusal dos discos com área de dentina exposta de $0,286 \mathrm{~cm}^{2}$, sob pressão de $200 \mathrm{~cm} \mathrm{H} \mathrm{H}_{2} \mathrm{O}$. O aumento da condutividade (Lp) conforme o aumento da temperatura foi altamente significante, tanto na dentina condicionada quanto na não condicionada. $\mathrm{O}$ aumento da temperatura em $40^{\circ} \mathrm{C}$ (de 10 a $50^{\circ} \mathrm{C}$ ) resultou num aumento de 1,8 vezes (de 0 a $179 \%$ ) no fluxo do fluido na dentina não condicionada, o que é similar em magnitude ao decréscimo em viscosidade ocorrido sob a mesma variação de temperatura. $\mathrm{Na}$ dentina condicionada por ácido, a mudança de $40^{\circ} \mathrm{C}$ na temperatura produziu um aumento maior do que 4 vezes (de 0 a 406\%) na condutividade do fluido, mais do que o dobro do que foi calculado para as mudanças na viscosidade. Então, observou-se que quanto maior a temperatura, menor a viscosidade do líquido e maior o diâmetro dos túbulos. As análises dos dados sugerem que este aumento adicional da condutividade hidráulica é devido à expansão térmica induzida, aumentando o diâmetro tubular. 


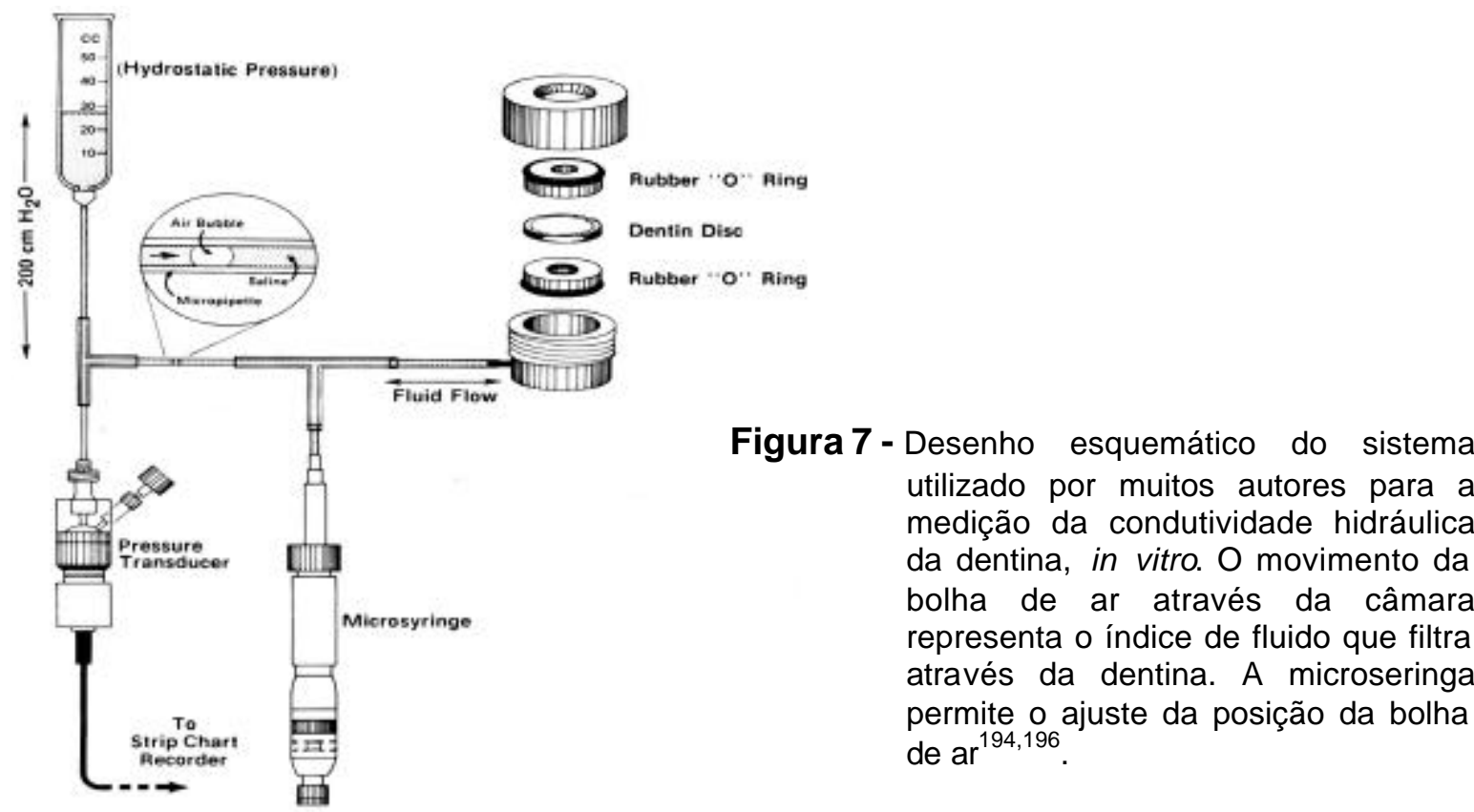

Pashley, Stewart e Galloway ${ }^{194}$, em 1984, avaliaram os efeitos evaporativos produzidos por jatos de ar de 0, 0,5, 2 e 5 minutos na permeabilidade da dentina, in vitro. A superfície pulpar dos discos de dentina obtidos de terceiros molares, com 0,5 a 0,8 mm de espessura, foi condicionada por dois minutos com ácido cítrico a $6 \%$, mantendo a smear layer intacta na superfície oclusal. Os discos foram adaptados à câmara de medição da condutividade (Figura 7), com uma área de superfície dentinária exposta de 0,282 $\mathrm{cm}^{2}$, de forma que a pressão de $30 \mathrm{~cm} \mathrm{H}_{2} \mathrm{O}$ fosse aplicada no lado pulpar. Quando os túbulos foram preenchidos com água, a evaporação prolongada não teve efeito na condutividade hidráulica (100\%). Os túbulos preenchidos com solução fisiológica produziram um decréscimo na condutividade hidráulica na dependência do tempo, de 79 a $69 \%$. E os valores encontrados para os túbulos preenchidos com 1,5\% de albumina em soro, de 84 a $58 \%$, foram semelhantes aos encontrados para os preenchidos com $1,5 \%$ de albumina em água, estes proporcionaram as maiores reduções na condutividade hidráulica, de 77 a $50 \%$. Estes efeitos foram mais marcantes na dentina não condicionada em oposição à dentina da face oclusal dos discos, tratada com ácido cítrico a $6 \%$ por dois minutos, apesar de não 
alcançar valores estatisticamente significantes. Os resultados sugerem que jatos de ar prolongados diminuem a permeabilidade dentinária e que parte da redução da hiperestesia dentinária produzida clinicamente por esses jatos pode ser devido à precipitação de constituintes orgânicos e inorgânicos do fluido dentinário na superfície.

Pashley et al. ${ }^{168}$, em 1984, avaliaram o efeito in vitro na condutividade hidráulica da dentina de uma variedade de dentifrícios anti-hiperestésicos, seus placebos e soluções apenas com os ingredientes ativos, além de um dentifrício experimental contendo oxalato de potássio a $2 \%$. Os discos de dentina foram condicionados com ácido cítrico a $6 \%$ durante dois minutos antes de serem adaptados à câmara de medição da condutividade hidráulica (Figura 7). A filtração da solução salina tamponada através da área de superfície dentinária de $0,282 \mathrm{~cm}^{2}$, sob pressão de $200 \mathrm{~cm} \mathrm{H}_{2} \mathrm{O}$, ocorreu sempre na direção polpa-esmalte. Os dentifrícios foram escovados na superfície dentinária oclusal do disco por um minuto com 120 movimentos circulares. Todos os dentifrícios reduziram a condutividade hidráulica da dentina em relação a solução salina, sendo tanto menor quanto menor a diluição do dentifrício. O dentifrício experimental contendo oxalato de potássio a $2 \%$ como ingrediente ativo foi mais efetivo, reduzindo a permeabilidade em 95\%. Não houve diferença estatisticamente significante entre os dentifrícios e os correspondentes placebo, exceto para o que contém oxalato, o mesmo ocorreu em relação as soluções apenas com os ingredientes ativos. Os resultados tendem a suportar a hipótese de que, no mínimo parte da redução da hiperestesia dentinária é devido à ação abrasiva dos dentifrícios.

Pashley e Galloway ${ }^{181}$, em 1985 , investigaram os efeitos do tratamento com oxalato de potássio na smear layer dentinária. Utilizaram discos de dentina, obtidos a partir de terceiros molares, condicionados no lado pulpar com ácido cítrico a 6\%, durante dois minutos. A smear layer foi avaliada através de condutividade hidráulica (Figura 8) e de microscopia eletrônica de varredura, antes e após dois minutos de tratamento tópico com cloreto de potássio a $3 \%$, oxalato dipotássio neutro a $30 \%$, solução de oxalato 
monopotássio mono-hidrogenado a 3\%, ou com a combinação de ambos ácidos oxálicos neutro e acidificado. A smear layer tratada foi então reavaliada microscopicamente e funcionalmente tanto antes quanto após ao desafio com ácido cítrico a 6\%, durante dois minutos. Os resultados de filtração para os vários tratamentos da smear layer foram, respectivamente: 100\%, 26\%, 23\%, 12\%. A smear layer estudada microscópica e funcionalmente foi suscetível ao condicionamento ácido (Figura9). As superfícies dentinárias tratadas com as soluções de oxalato foram menos permeáveis e foram ácido resistentes. Microscopicamente, o tratamento da smear layer com oxalato dipotássio a 30\% formou cristais irregulares e grandes, de $1 \times 5 \mu \mathrm{m}$, que permaneceram ocluindo as embocaduras tubulares após o desafio ácido, apesar da remoção do material amorfo entre os cristais (Figura 10). O oxalato monopotássio monohidrogenado a $3 \%$ apresentou uma superfície diferente da anterior, também granulosa, mas formada por com cristais menores, havendo pouca modificação superficial após o desafio ácido (Figura 11). A combinação das soluções proporcionou uma superfície heterogênea coberta com uma mistura de cristais, que mostraram uma pequena modificação após o desafio ácido (Figura 12). As soluções de oxalato se comportaram de maneira semelhante entre si tanto antes quanto após ao desafio ácido, e significativamente reduziram a permeabilidade dentinária quando comparados com seu controle.

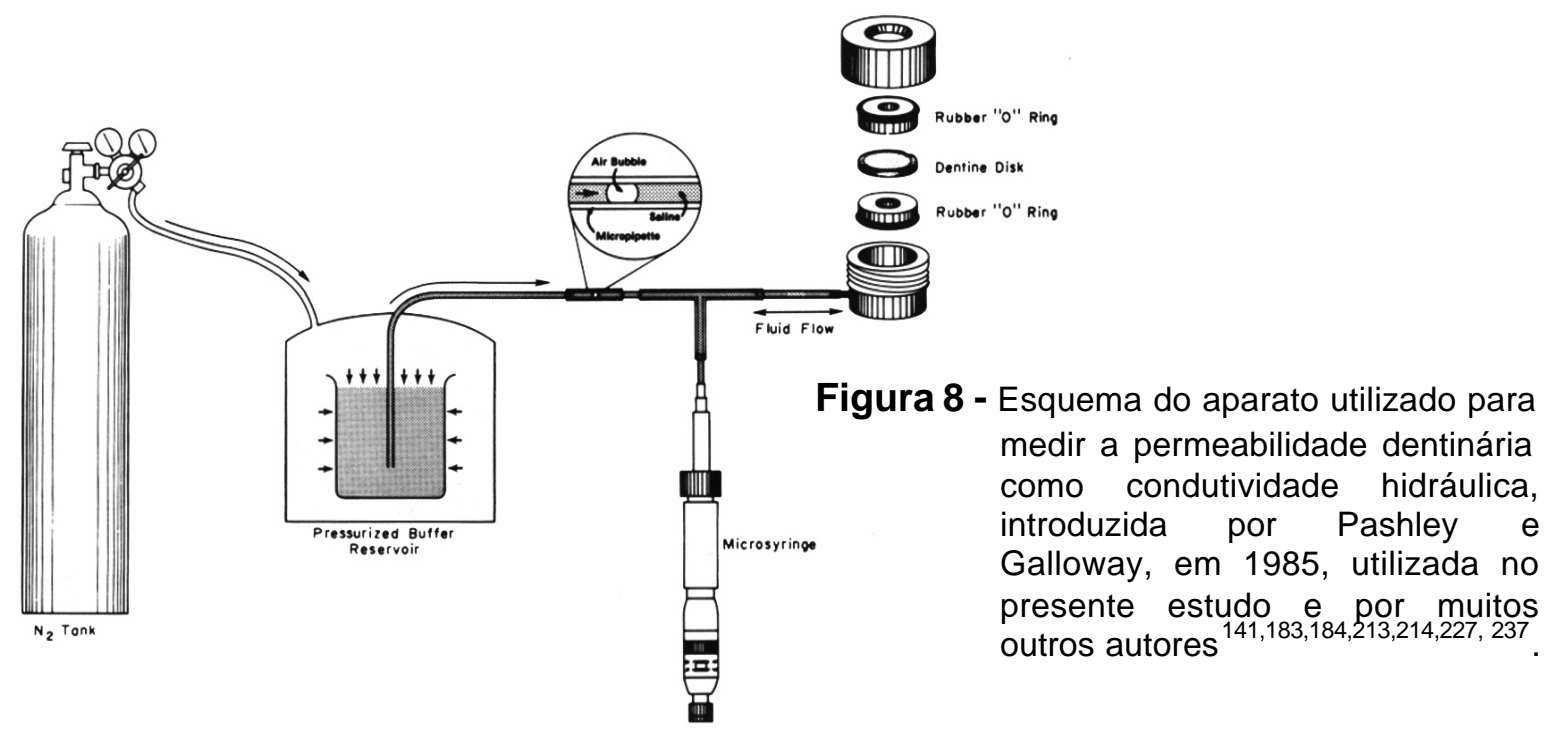



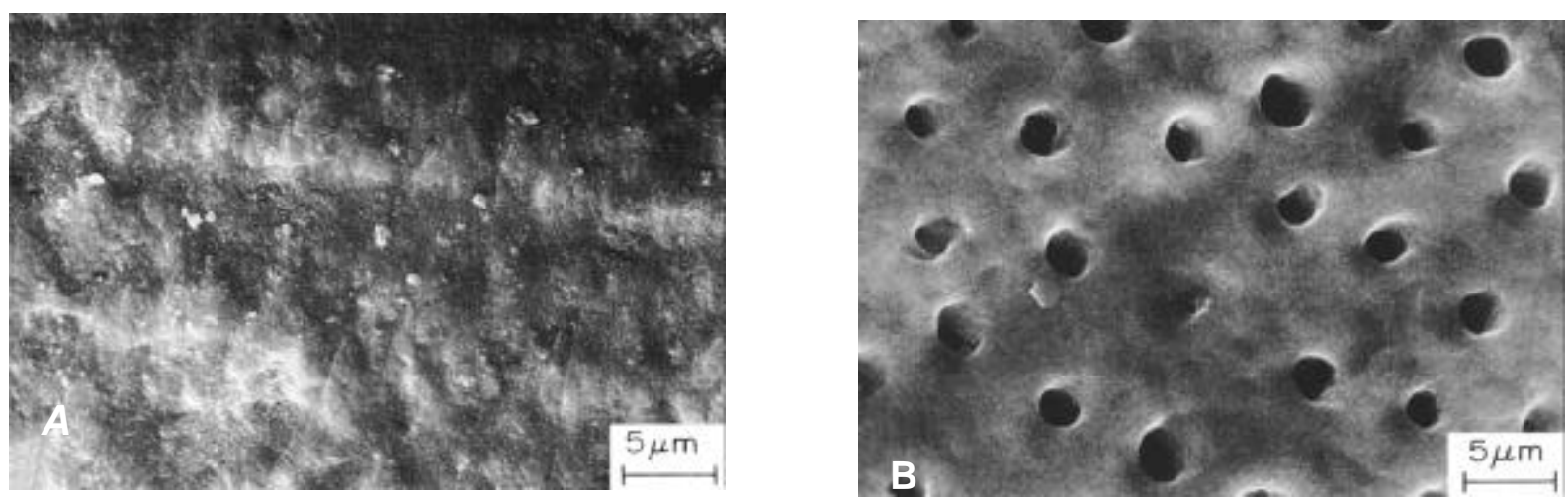

Figura 9 - A - Aparência homogênea e amorfa da smear layer, B - Remoção da smear layer pelo ácido cítrico a $6 \%$, revelando os orifícios tubulares ${ }^{181}$.
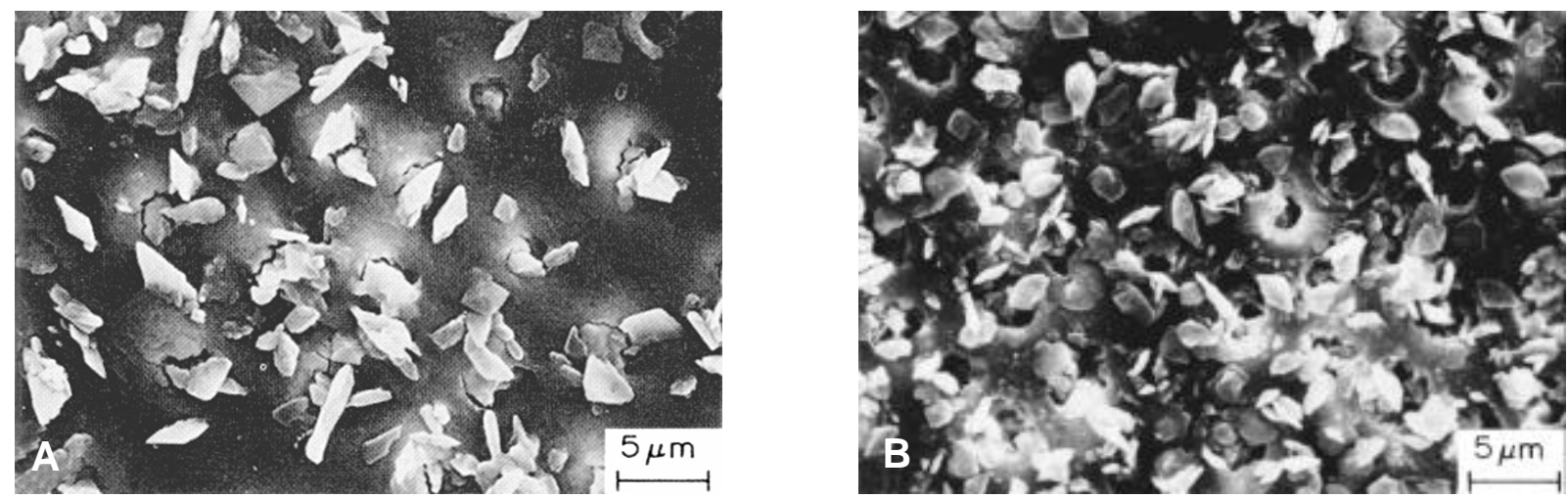

Figura 10 - A-Smear layer tratada com oxalato dipotássio a $30 \%(\mathrm{pH} 7)$ por 2 minutos. Nota-se a formação de cristais amplos e irregulares; B-Smear layer tratada com oxalato dipotássio a $30 \%$ por 2 minutos, seguida por desafio ácido. $O$ condicionamento removeu o material amorfo e homogêneo ao redor dos cristais maiores ${ }^{181}$.
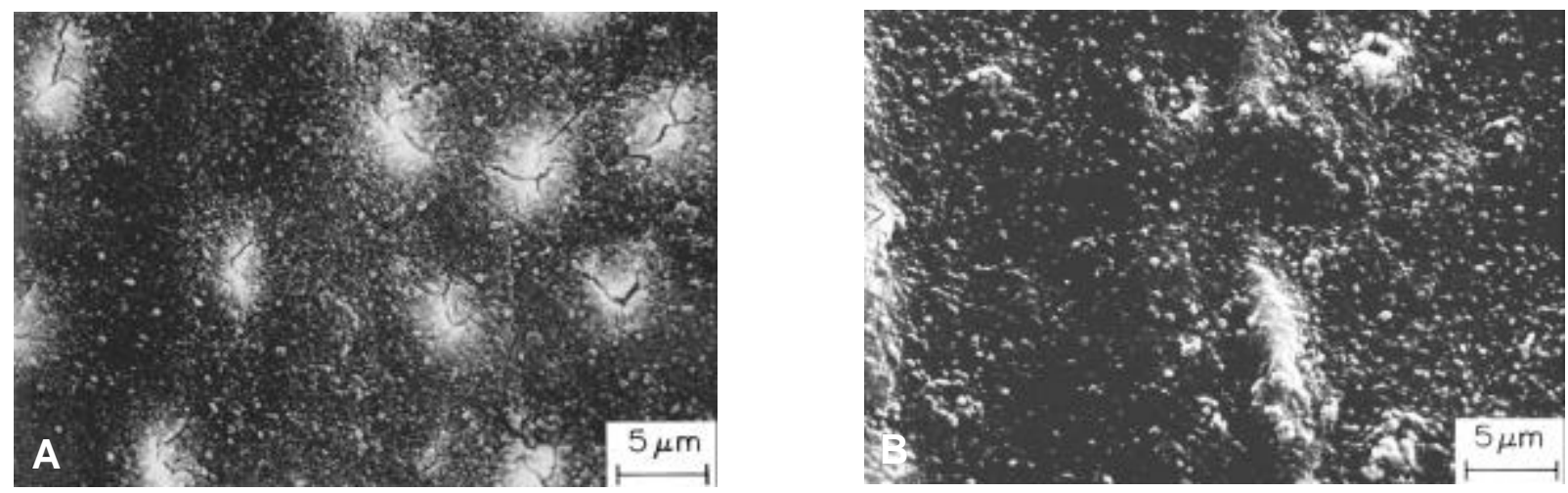

Figura 11 - A-Smear layer tratada com oxalato de potássio a $3 \%(\mathrm{pH} 2)$ por 2 minutos. A superfície esta diferente tanto da smear layer quanto da tratada com oxalato de potássio a $30 \%$, mas com granulos mais finos; $\mathbf{B}$ - Superfície tratada com oxalato de potássio a $3 \%(\mathrm{pH} 2)$ por 2 minutos seguida pelo desafio com ácido cítrico. Nota-se pouca mudança na superfície ${ }^{181}$. 

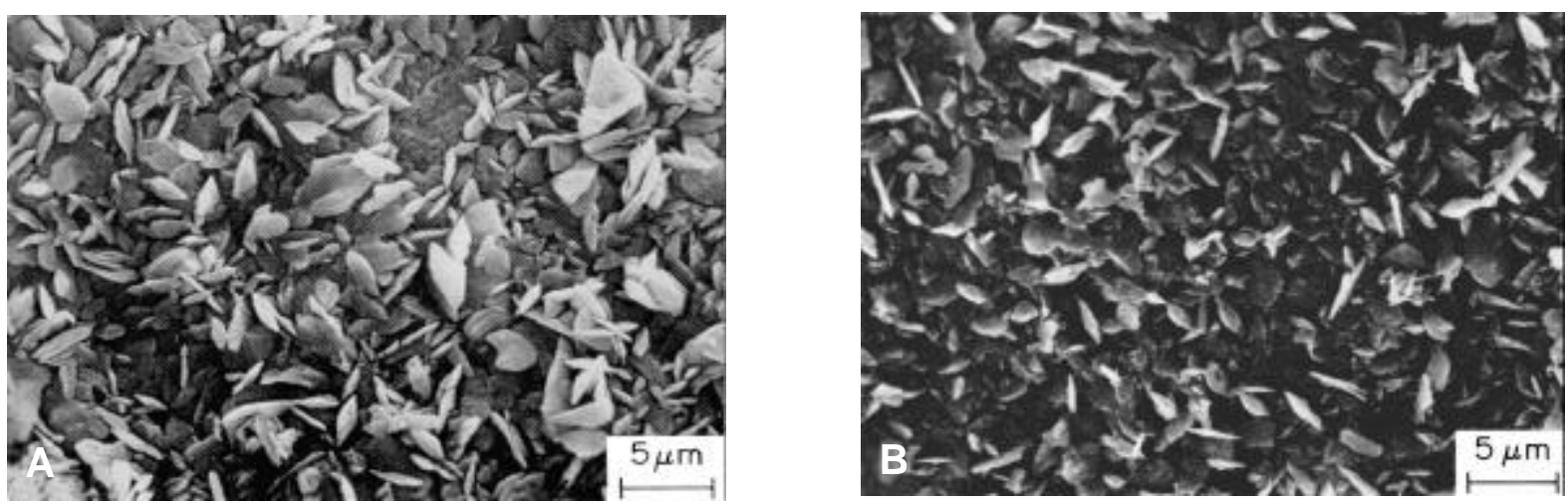

Figura 12 - A-Smear layer tratada com oxalato dipotássio a $30 \%$ por 2 minutos, seguido do tratamento com oxalato de potássio a $3 \%$. Nota-se que a superfície dentinária está coberta por um arranjo heterogênio de cristais; $\mathbf{B}$ - Desafio ácido com acido cítrica a $6 \%$ por 2 minutos. Observa-se poucas modificações na superfície ${ }^{181}$.

Os objetivos deste estudo in vitro de Pashley e Depew ${ }^{180}$, em 1986, foram quantificar os efeitos da smear layer, do oxalato de potássio e do verniz cavitário em cavidades de classe I de terceiros molares em relação a permeabilidade dentinária e a microinfiltração. O sistema de medição da condutividade hidráulica foi modificado para receber a porção coronária do dente com os preparos cavitários (Figura 13A). As medições foram feitas com e sem restauração de amálgama, antes e depois dos diferentes tratamentos, dentre os quais: smear layer intacta, com ácido cítrico a $6 \%$ por dois minutos, verniz Copalite, e tratamento com ácido oxálico meio neutralizado a 3\% por dois minutos. Os resultados mostraram que o tratamento das cavidades condicionadas com ácido oxálico a $3 \%$, restauradas ou não, levou a uma redução significante da permeabilidade em $98,25 \%$. A mudança de direção da filtração não modificou os resultados no caso dos oxalatos, mas isto ocorreu para as cavidades tratadas com copalite, onde a direção de filtração polpacavidade produziu maior permeabilidade. Não houve diferença entre amálgamas forrados com oxalato ou copalite. Quanto à microinfiltração, as cavidades tratadas com copalite apresentaram maior redução quando comparadas com o oxalato, porém este apresentou melhores resultados do que as cavidades com smear layer. Observaram, portanto, que os 
sais de oxalato merecem consideração como forradores cavitários potentes por reduzir a permeabilidade dentinária e conseqüentemente, a sensibilidade do paciente.

Pashley, Kalathoor e Burnham ${ }^{183}$, em 1986, determinaram os efeitos do hidróxido de cálcio na condutividade hidráulica, in vitro, com e sem a presença da smear layer. Os discos de dentina, com 0,5 a $0,9 \mathrm{~mm}$ de espessura, obtidos a partir de terceiros molares humanos, foram adaptados ao sistema para medição da condutividade (Figura 8). A área de superfície dentinária exposta foi de $0,317 \mathrm{~cm}^{2}$ e a pressão hidráulica variou entre 0,069 e 0,241 MPa para a filtração com solução salina na direção polpa-esmalte. A condutividade hidráulica foi medida numa seqüência de situações, sendo que o tratamento das superfícies condicionadas com pasta de hidróxido de cálcio, reduziu a permeabilidade dentinária em $75 \%$. A smear layer provocou a redução da permeabilidade em $99 \%$ e a subseqüente aplicação do hidróxido de cálcio reduziu ainda mais esta permeabilidade em $48 \%$. Porém, sob o desafio com ácido cítrico, a permeabilidade dentinária retornou ao valor inicial da dentina condicionada. Microscopicamente, o tratamento com hidróxido de cálcio produziu discreta redução nas dimensões dos túbulos da dentina condicionada, mas nenhuma mudança aparente na dentina com smear layer. A pasta de hidróxido de cálcio mostrou-se efetiva na redução da permeabilidade dentinária in vitro, mas oferece pequena proteção ao desafio ácido.

Os efeitos da brunidura de fluoreto de sódio, Kaolin, e glicerina, isoladamente ou em várias combinações na permeabilidade dentinária, foram determinados em 1987, por Pashley, Leibach e Horner ${ }^{187}$. Os discos de dentina, adaptados no sistema de medição da condutividade hidráulica (Figura 8), foram submetidos à filtração na direção polpa-esmalte, sob pressão hidrostática de $1,05 \mathrm{~kg} / \mathrm{cm}^{2}$, em uma área de superfície de $0,317 \mathrm{~cm}^{2}$. Os discos previamente condicionados com ácido cítrico a $6 \%$ durante 2 minutos, foram testados sob diferentes condições entre condicionamento ácido; brunidura com bastão de madeira, espátula plástica ou metálica; aplicação de diferentes combinações entre fluoreto de sódio, 
cloreto do sódio, kaolin e glicerina; e aplicação tópica de ácido oxálico a 3\% por 2 minutos. O tratamento a seco com bastões de madeira promoveu a maior redução ( $80 \%$ ) na condutividade entre os grupos que utilizaram a brunidura, sendo que a aplicação tópica de ácido oxálico reduziu a permeabilidade em $96 \%$ sem qualquer brunidura. Estes grupos foram resistentes ao desafio com ácido cítrico. Microscopicamente, os discos tratados com oxalato de monopotássio mono-hidrogenado a 3\% exibiram uma superfície com maior número de túbulos ocluídos com grandes cristais de oxalato de cálcio. Os resultados indicaram, então, que a variável importante não foi qualquer dos constituintes das pastas, mas o processo de brunidura em si. A aplicação tópica de ácido oxálico foi mais efetiva na redução da permeabilidade dentinária e não requer brunidura.

A variabilidade regional da permeabilidade da dentina humana foi avaliada in vitro por Pashley et al. ${ }^{161}$, em 1987, isto é, determinaram se a permeabilidade dentinária de segmentos coronários e de discos de dentina, preparados a partir daqueles segmentos, é heterogênea ou homogênea. A permeabilidade foi medida, qualitativamente, utilizando corantes em segmentos de coroa e discos de dentina, e quantitativamente, por meio da condutividade hidráulica em discos de dentina. Para o estudo qualitativo, os segmentos coronários foram preparados a partir de terceiros molares e cimentados numa plataforma de acrílico do sistema de medição (Figura 13A). A solução salina fosfatada foi filtrada com corante azul, na direção polpa-superfície oclusal, sob pressão hidrostática de 0,034 Mpa. O corante permitiu a visualização e a fotografia de onde o fluido estava permeando. Para o estudo quantitativo foram preparados, daqueles segmentos coronários, discos com $1 \mathrm{~mm}$ de espessura. Após remoção da smear layer com ácido cítrico a $6 \%$ por dois minutos, os discos foram adaptados à câmara de medição da permeabilidade utilizando uma área de superfície de $0,126 \mathrm{~cm}^{2}$. As medições foram feitas no centro do disco de dentina e em outras quatro regiões periféricas. Outro estudo qualitativo foi feito com os discos de dentina, adaptando-os numa depressão cônica, sobre uma plataforma acrílica (Figura 13B). O fluido 
contendo corante azul foi filtrado e o padrão de permeabilidade regional da dentina, fotografado (Figura 14). Nos segmentos coronários, a permeabilidade não foi uniforme, sendo o corante azul mais evidente acima dos cornos pulpares e menos no centro da coroa. Quando comparados com os discos de dentina, o padrão de permeabilidade foi similar apesar de apenas estes últimos apresentarem espessura uniforme, o que pode ser explicado pelo maior diâmetro e número de túbulos em regiões mais próximas aos cornos pulpares. Ambas as formas de preparo demonstraram diferenças regionais amplas em permeabilidade, com os maiores valores na periferia e os menores no centro do disco ou da coroa. Como a permeabilidade dentinária pode variar de três a dez vezes em poucos milímetros, os investigadores devem usar a maior área de superfície possível para compensar essas diferenças regionais.

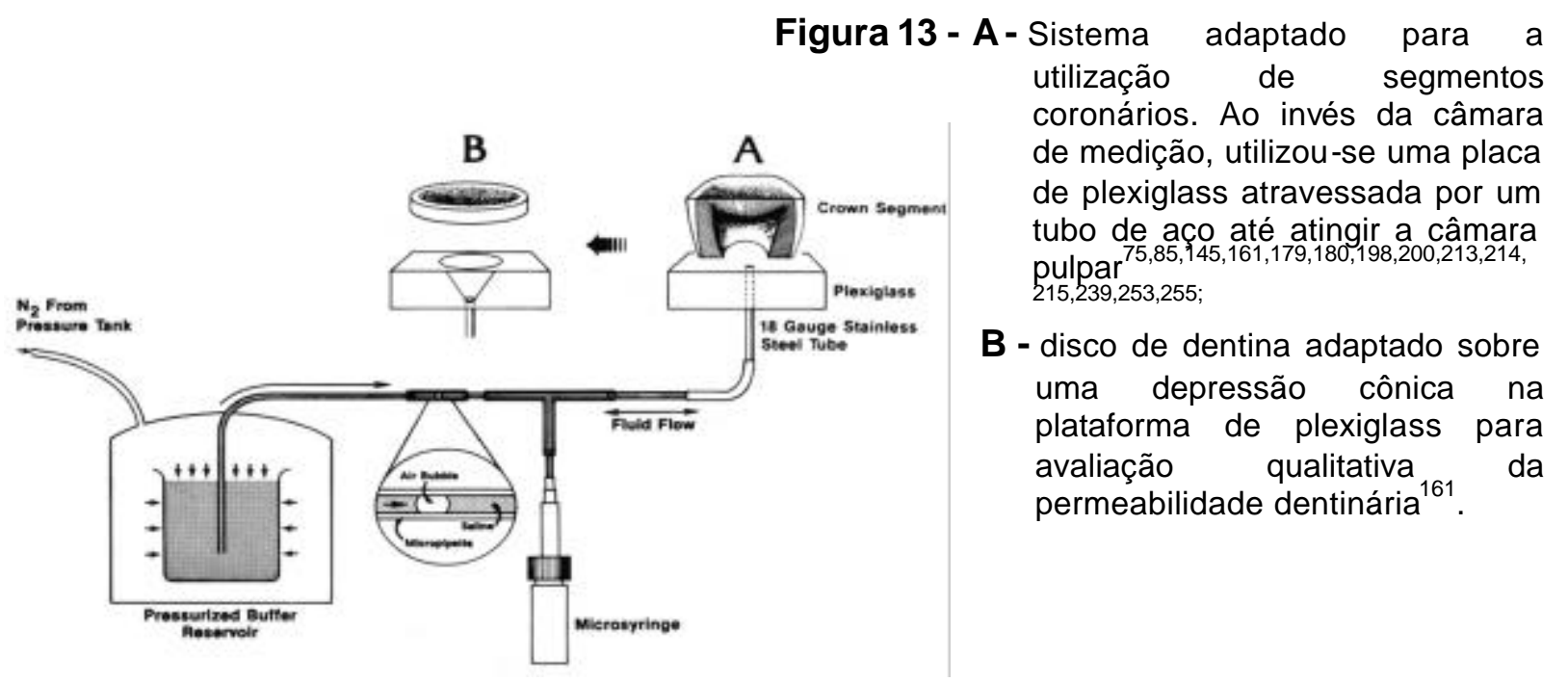

Figura 14 - Fotografia das diferenças regionais da permeabilidade em discos de dentina ${ }^{161}$.

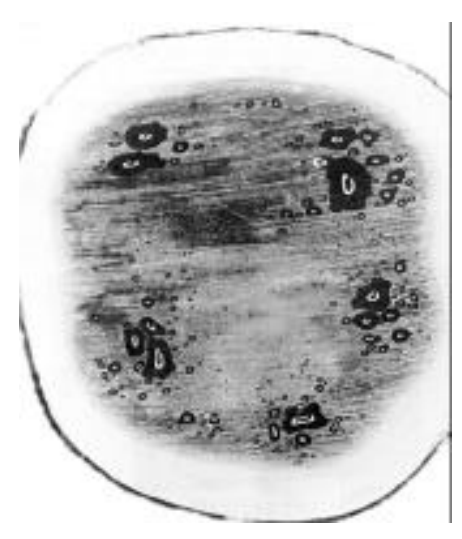


Fogel e Pashley ${ }^{63}$, em 1990, investigaram os efeitos do tratamento da smear layer com cloreto de sódio a 5\%, ácido cítrico a $50 \%$, ou oxalato de monopotássio monohidrogenado a 3\% (Protect) na condutividade hidráulica da dentina radicular. Após a remoção das coroas dos terceiros molares, os segmentos radiculares foram preparados para serem adaptados ao aparato de medição da condutividade hidráulica (Figura 15). A filtração máxima foi obtida após a imersão dos espécimes em ácido cítrico a $50 \%$ durante dois minutos. A permeabilidade não foi afetada pelo tratamento com cloreto de sódio, mas aumentou muitas vezes após o tratamento com ácido cítrico por dois minutos. O tratamento com oxalato diminuiu a permeabilidade dentinária radicular a níveis abaixo dos produzidos pela criação da smear layer devido à produção de precipitados cristalinos finos, observados microscopicamente cobrindo as aberturas tubulares.

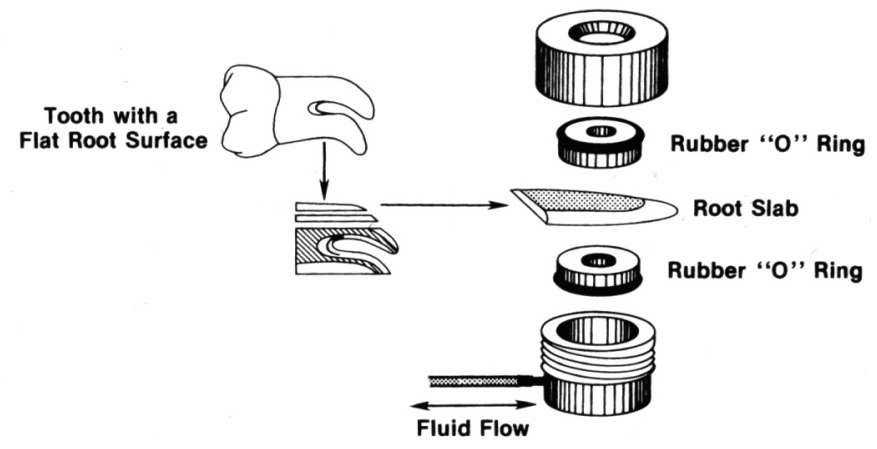

Figura 15 - Demonstração esquemática dos espécimes radiculares e de como foram adaptados na câmara de filtração $0^{61,63}$

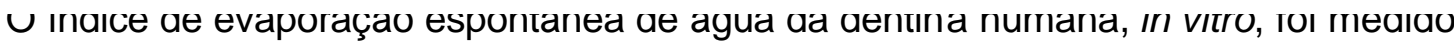
por Goodis, Tao e Pashley ${ }^{75}$, em 1990. Para o experimento foram preparados segmentos de coroa, a partir do corte de terceiros molares. O segmento coronário foi adaptado ao sistema de filtração despressurizado (Figura 13A), a fim de que a condutividade hidráulica fosse determinada após o tratamento com EDTA 0,5 M durante dois minutos e, em seguida a simulação da smear layer com lixa 320 por cinco segundos, sob força de $500 \mathrm{~g}$ a uma rotação de 108 revoluções/minuto. A área de superfície por onde a água destilada filtrou foi determinada fotograficamente. Após estas medições, o espécime foi conectado a um capilar 
mais sensível num sistema despressurizado para medir a evaporação nas seguintes situações: dentina coberta com e sem uma gota de água, com jato de ar por um minuto sob três ângulos diferentes. A smear layer foi removida com EDTA a 0,5 $\mathrm{M}$ e foram repetidas todas as medições descritas acima. Independentemente da presença ou da ausência da smear layer, a perda espontânea de água foi a mesma e, o índice de evaporação aumentou significativamente quando o ar foi direcionado para a dentina. Após a remoção da smear layer, os valores da evaporação duplicaram.

Num experimento in vitro, em 1991, Pashley, Andringa e Eichmiller ${ }^{179}$ compararam a eficiência do oxalato de ferro e do oxalato de alumínio na redução da permeabilidade dentinária. Em segmentos de coroas de terceiros molares foram aplicados quatro tratamentos: oxalato de alumínio 6,8\% em ácido nítrico a 2,5\%, oxalato de ferro em ácido nítrico a 2,5\%, Tenure e ácido nítrico a 2,5\%, aplicados por 10, 30 e 60 segundos. Uma pressão de 10 psi foi utilizada para filtrar a solução salina no sistema de medição (Figura 13A). Antes da aplicação dos agentes, mediram a permeabilidade máxima, através do condicionamento com EDTA 0,5 M e pH 7,4 durante um minuto, e a mínima, após a simulação da smear layer por meio de abrasionamento mecânico durante cinco segundos. Os resultados indicaram que o tratamento da dentina por 30 segundos proporcionou a diminuição da permeabilidade dentinária para as soluções à base de oxalato. E o tratamento com Tenure durante 60 segundos não reduziu a permeabilidade dentinária aos níveis dos tratamentos com oxalatos. Isto pode ser explicado devido à concentração reduzida de oxalato no Tenure e pela necessidade de um maior tempo de aplicação para a formação de sais insolúveis, o que para as soluções à base de oxalato parece ocorrer após 30 segundos de aplicação.

Tagami et al. ${ }^{253}$, em 1991, compararam os efeitos do corte da dentina com broca diamantada em alta velocidade, com e sem refrigeração, e da lixa de carbeto de silício de granulação 80, na permeabilidade dentinária e na resistência adesiva. Segmentos de 
terceiros molares foram seccionados e adaptados no sistema para o exame de condutividade hidráulica (Figura 13A) . A permeabilidade máxima foi medida após o condicionamento da dentina com EDTA a 0,5 M durante dois minutos, e a mínima, através da criação da smear layer com broca ou com lixa. Outra medição foi feita após o desafio da smear layer com ácido fosfórico gel a 37\% por um minuto ou com ácido cítrico com cloreto férrico por 30 segundos. Os sistemas adesivos Scotchbond DC, Clearfil PhotoBond e Superbond $\mathrm{C} \& \mathrm{~B}$ foram testados com relação à resistência ao cisalhamento, utilizando segmentos coronários sob uma força de $829 \mathrm{~g} / \mathrm{min}$. A produção da smear layer pelo corte da broca ou pelo lixamento reduziu a permeabilidade dentinária de 1 a $3 \%$. O aumento da permeabilidade da dentina após o tratamento com ácido fosfórico foi maior quando foi utilizada a lixa de carbeto de silício em relação a broca em alta velocidade. Em microscopia eletrônica de varredura, não houve diferença aparente entre as smear layers criadas das variadas formas. A smear layer e smear plugs produzidos pela broca diamantada foram mais resistentes ao tratamento com ácido cítrico com cloreto férrico do que a smear layer criada pela lixa.

Apesar de haver publicações demostrando que a dentina cariada é menos permeável do que a normal, essa pesquisa de Pashley et al. ${ }^{200}$, em 1991, teve uma abordagem mais qualitativa do que quantitativa em termos de permeabilidade dentinária. Segmentos coronários com uma lesão cariosa na região mésio ou distooclusal foram selecionados e submetidos aos testes de condutividade hidráulica (Figura 13A), com pressão hidrostática de $703 \mathrm{~cm} \mathrm{H} \mathrm{H}_{2} \mathrm{O}$. As medições foram realizadas antes e após a escavação da cárie com brocas, após a remoção da smear layer com ácido cítrico a $6 \%$ por dois minutos, após o preparo de uma cavidade controle em dentina normal com tamanho e profundidade similares à lesão cariosa, e após a remoção da smear layer desta cavidade. As lesões cariosas exibiram um leve grau de permeabilidade que permaneceu imutável após a escavação das lesões, sendo que a remoção da smear layer dessas lesões aumentou 
significativamente a permeabilidade dentinária, entretanto, uma cavidade controle com a mesma área e profundidade mostrou maior permeabilidade. A remoção da smear layer aumentou a permeabilidade em $91 \%$. A microscopia eletrônica revelou na dentina cariada, a presença de dentina esclerótica após a escavação, smear layer com partículas grandes e irregulares, presença de depósitos minerais nos túbulos e resíduos ácido resistentes na superfície. A smear layer é a grande responsável pela modificação da permeabilidade dentinária da dentina normal. Estes resultados confirmam os estudos qualitativos prévios nos quais a dentina cariada mesmo após a escavação e remoção da smear layer tem permeabilidade muito baixa.

Prati et al. $^{214}$, em 1991, avaliaram o efeito de diferentes soluções ácidas na permeabilidade dentinária e correlacionaram-na com a morfologia dentinária. Discos dentinários foram adaptados ao aparato de medição da permeabilidade (Figura 8), sendo a superfície dentinária tratada durante um minuto com diferentes agentes químicos. A permeabilidade máxima foi obtida pelo tratamento dentinário com ácido fosfórico a $37 \%$ durante dois minutos. O ácido maleico a $10 \%$ foi responsável pelo maior valor de permeabilidade, seguido do ácido fosfórico a $37 \%$ e ácido poliacrílico a $25 \%$. As análises em microscopia confirmaram os dados de permeabilidade, registrando a remoção completa da smear layer com a exposição de fibras colágenas quando as soluções ácidas foram aplicadas sobre a dentina.

A habilidade do dispositivo Periotron em medir a permeabilidade e a umidade dentinária foi avaliada in vitro por Prati et al. ${ }^{213}$, em 1991. Os experimentos de permeabilidade e umidade utilizaram-se de segmentos coronários de terceiros molares, sob diferentes pressões pulpares, 0, 40 e $703 \mathrm{~cm} \mathrm{H}_{2} \mathrm{O}$, tanto na presença como na ausência da smear layer, e na presença do sistema adesivo Scotchbond 2. Na superfície dos segmentos de coroa, uma área dentinária com maior permeabilidade foi selecionada para a realização dos testes (Figura 13A), a região ao redor foi isolada e tratada com Protect que permitiu a 
redução de $98 \%$ na permeabilidade. A smear layer foi criada com lixa 320 durante cinco segundos e a máxima permeabilidade obtida com o ácido fosfórico a 37\%, aplicado por 30 segundos. A resistência adesiva foi determinada na máquina Instron, utilizando uma velocidade de $0,5 \mathrm{~mm} /$ minuto. A correlação entre a umidade determinada pelo Periotron e a permeabilidade da dentina foi altamente significante. E os resultados da resistência ao cisalhamento do Scotchbond 2/Silux sugeriu que o aumento da umidade diminui a resistência adesiva daquele sistema.

Prati e Pashley ${ }^{215}$, em 1992, avaliaram a correlação entre as condições dentinárias relativas à umidade, permeabilidade e espessura, com a resistência adesiva. Este experimento foi realizado com o sistema ilustrado na Figura 13A Diferentes correlações significantes foram observadas entre a permeabilidade, umidade, espessura e resistência adesiva dos sistemas Scotchbond 2, Tenure e All-Bond. Nenhuma correlação aparente foi observada para o Clearfil PhotoBond e Vitrabond. A implicação clínica deste estudo referese à maior atenção em termos da escolha do tratamento a ser realizado na área de dentina profunda oclusal, pois é mais úmida do que a superficial.

Mongiorgi et al. ${ }^{141}$, em 1992, tentaram demostrar que a smear layer produzida utilizando solução de oxalato é composta de oxalato de cálcio. A condutividade hidráulica de terceiros molares, cortados na forma de discos dentinários, foi medida após o emprego de três soluções à base de oxalato: OKSolution, DDS e Dentin Protect. Também foi analisada a filtração após a aplicação de solução salina a 0,9\% e ácido fosfórico (Figura 8). A reação entre dentes reduzidos a pó, considerados como smear layer sintética, e a solução de oxalato de potássio a $30 \%$ por dois minutos, mostrou por intermédio da análise de difração de raios $\mathrm{X}$, a produção de quantidades detectáveis de oxalato de cálcio. Os resultados percentuais de permeabilidade dentinária para o OKSolution, DDS e Dentin Protect, foram 2,2, 3,5 e 3,9, respectivamente. Para a smear layer foi 2,9\% e para o ácido fosfórico, 100\%. 
A microscopia mostrou a presença de uma camada de cristais homogênea cobrindo os túbulos dentinários nos espécimes tratados com as soluções à base de oxalato.

Simpson et al. ${ }^{239}$, em 1992, avaliaram o efeito do tratamento da smear layer com soluções de oxalato de alumínio na permeabilidade da dentina humana, empregando testes de condutividade hidráulica (Figura 13A) e de microscopia eletrônica. A filtração máxima foi obtida após o condicionamento da superfície dentinária com ácido fosfórico a 37\%, seguido da obtenção da filtração na presença da smear layer, preparada com lixa 320. Outra medição, sempre sob pressão de $703 \mathrm{~cm} \mathrm{H} \mathrm{H}_{2} \mathrm{O}$, foi feita após o condicionamento da dentina por um minuto com cinco diferentes soluções de oxalato de alumínio, obtidas pelas variações de $\mathrm{pH}$ de 0,5 a 2,5. As soluções de oxalato de alumínio removeram a maior parte da smear layer original, mas mantiveram os túbulos obstruídos com depósitos cristalinos, os quais diminuíram a permeabilidade dentinária. As soluções utilizadas com $\mathrm{pH} 2,0$ e 2,5 aumentaram a permeabilidade dentinária. Todos os tratamentos dentinários aumentaram a permeabilidade dentinária quando medida depois de 24 horas, especialmente as soluções com pH mais elevado. A comparação dos resultados da microscopia eletrônica de varredura com as alterações na permeabilidade, indicaram que estas soluções removem a smear layer mas reocluem os túbulos com precipitados, os quais são, provavelmente, diferentes formas de oxalato de cálcio, fosfato de alumínio e fosfato de cálcio.

Fogel e Pashley ${ }^{61}$, em 1993, quantificaram os efeitos da raspagem periodontal radicular na permeabilidade da dentina radicular. A natureza da smear layer criada pela instrumentação periodontal e os efeitos da aplicação do oxalato de potássio também foram investigados. As coroas foram removidas dos terceiros molares selecionados e fatias longitudinais foram feitas das raízes, obtendo-se uma seção interna, composta apenas de dentina e outra externa, com dentina superficial e cemento (Figura 15). As seções foram adaptadas ao aparato para medição da permeabilidade e expostas a uma pressão de $1050 \mathrm{~cm} \mathrm{H} \mathrm{H}_{2} \mathrm{O}$. A condutividade hidráulica da dentina radicular foi medida num período de 
dez minutos, antes e depois da raspagem radicular, após o condicionamento com ácido cítrico a $50 \%$ por dois minutos e após a aplicação do oxalato de monopotássio monohidrogenado a $3 \%$ durante dois minutos. A raspagem radicular criou uma smear layer que reduziu a permeabilidade dentinária, entretanto, esta smear layer não é ácido resistente, levando ao aumento futuro da permeabilidade dentinária. A condutividade hidráulica reduziu após a aplicação do oxalato de monopotássio monohidrogenado a 3\%. A microscopia eletrônica mostrou que o tratamento com oxalato de potássio cobriu a maior parte dos orifícios com um precipitado granular, sendo mais efetivo na dentina mais interna, pois os túbulos mais largos desta dentina se adaptam melhor ao tamanho dos cristais de oxalato de cálcio. A vantagem de ocluir os túbulos com oxalato de cálcio em relação a smear layer é a sua resistência ao meio ácido.

Matthews, Showman e Pashley ${ }^{131}$, em 1993, in vitro, mediram os efeitos evaporativos de água da dentina em condições espontâneas, na presença ou ausência da smear layer, e variando a temperatura, a distância e a direção do ar. Foram preparados segmentos de coroa de terceiros molares, com o plano oclusal dentinário livre, e adaptados num dispositivo para medição da evaporação de água (Figura 16). A medição foi feita de acordo com a movimento de partículas de gordura suspensas na água, dentro do capilar do dispositivo de medição, conforme a evaporação de água do segmento coronário. Os jatos de ar induziram um aumento de 15 a 30 vezes na perda de água por evaporação, que variou inversamente com a distância do jato ao dente e diretamente com a temperatura do ar. Os resultados deste estudo significam que os pacientes reagem mais aos jatos de ar do que a outros estímulos dolorosos, porque o jatos induzem a evaporação da água mesmo através da smear layer ou da dentina tratada com oxalato. 


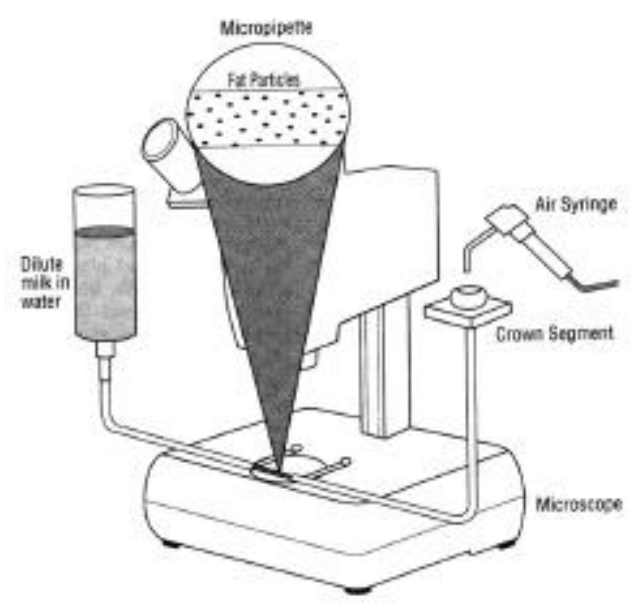

Figura 16 - Desenho esquemático do dispositivo utilizado para medir a evaporação de água da dentina ${ }^{131}$.

Mongiorgi e Prati ${ }^{144}$, em 1994, avaliaram a condutividade hidráulica da dentina in vitro após a aplicação de diferentes soluções de oxalato. Os depósitos superficiais produzidos pelo tratamento com oxalato foram também examinados em microscopia eletrônica de varredura e difração de raios X. Os espécimes, obtidos de terceiros molares, foram tratados previamente com ácido fosfórico a 37\% por dois minutos para remoção da smear layer. As soluções de oxalato utilizadas foram Dentin Protect, à base de ácido oxálico monopotássio mono-hidrogenado a 3\%; solução DDS, à base de oxalato di-potássio a 30\% e OK Solution, à base de oxalato dipotássio a 30\% e oxalato monopotássio monohidrogenado a 3\% A permeabilidade dentinária foi medida com a pressão de trabalho de $70 \mathrm{~cm} \mathrm{H} \mathrm{H}_{2} \mathrm{O}$, utilizando o sistema ilustrado na Figura 5. Todas as soluções de oxalato reduziram semelhantemente a permeabilidade a valores tão baixos quanto aos da smear layer e, microscopicamente, todas as soluções de oxalato cobriram a dentina com uma crosta de precipitados cristalinos. A suspensão de dentes reduzidos a pó, considerados como smear layer sintética, em solução de oxalato de dipotássio a 30\%, mostrou através da análise de difração de raios $\mathrm{X}$, a produção de quantidades detectáveis mas não abundantes de cristais oxalato de cálcio- $\gamma$ iso-orientados, os mesmos verificados em microscopia. O Dentin Protect, que mostrou melhor resultado numérico de permeabilidade, produziu uma camada de cristais grandes e irregulares que cobrem a superfície dentinária, fechando 
parcialmente os túbulos dentinários. As outras duas soluções de oxalato, OK Solution e DDS, produziram uma camada uniforme de resíduos com alguns cristais visíveis cobrindo completamente os túbulos dentinários. Estes resultados confirmaram, então, que as soluções de oxalato aplicadas nas superfícies dentinárias causam a deposição de cristais de oxalato de cálcio- $\gamma$.

Uma formulação de oxalato dipotássio a $5 \%$ e alumínio a $2 \%$ foi avaliada in vitro por Shono et al. $^{237}$, em 1994, quanto à redução da permeabilidade dentinária e alteração da aparência microscópica dos orifícios tubulares. Os segmentos coronários foram tratados com cloreto de sódio ou com a solução experimental com pH 2, por 10, 30 e 60 segundos. As medições de condutividade hidráulica (Figura 13A) foram realizadas antes e após o tratamento da dentina com ácido fosfórico a 37\% durante 15 segundos. Tanto na presença quanto na ausência da smear layer, o tratamento com a solução de oxalato reduziu significativamente a condutividade hidráulica. Observou-se uma significante oclusão dos túbulos por precipitados cristalinos, estes com diâmetros similares aos dos túbulos dentinários na dentina coberta pela smear layer e, com diâmetros menores e aberturas tubulares quase completamente cobertas quando a dentina foi condicionada com ácido. Porém, os cristais não se estenderam muito para dentro dos túbulos. Os resultados indicaram que de acordo com o aumento do tempo de tratamento, aumentam a reação da solução experimental com o mineral, a espessura da camada de precipitados e o tamanho dos precipitados. Os autores concluíram que as soluções de oxalato podem significativamente obstruir os túbulos dentinários, e podem ser efetivas como dessensibilizadores dentinários e forradores cavitários.

Em 1994, Mongiorgi, Prati e Ferrieri ${ }^{145}$ avaliaram, in vitro, a condutividade hidráulica de dentifrícios, in vitro, antes e depois do tratamento tópico com dentifrícios comerciais e um experimental, à base de oxalato de potássio. Segmentos coronários de terceiros molares foram adaptados ao sistema de medição da condutividade hidráulica 
(Figura 13A), e analisados sob uma pressão de 70,3 cm $\mathrm{H}_{2} \mathrm{O}$. Antes e após a aplicação das pastas por três minutos, a dentina foi condicionada com ácido fosfórico a 37\% por dois minutos, sendo o primeiro condicionamento para a remoção da smear layer e o segundo, como desafio ácido. O dentifrício experimental à base de oxalato de potássio causou a maior redução na permeabilidade dentinária (40\%), e também foi o único que resistiu ao desafio ácido, indicando a labilidade das outras pastas. A eficiência clínica destes produtos pode envolver outros mecanismos, como os efeitos dos íons potássio nos nervos pulpares.

Suge et al. $^{245}$, em 1995, estudaram a efetividade da oclusão dos túbulos dentinários por agentes anti-hiperestésicos em saliva sintética sob condições similares ao do ambiente oral. Os discos de dentina, com 0,5 mm de espessura e previamente condicionados com ácido cítrico a $50 \%$ por dois minutos, foram tratados pelo método de precipitação de fosfato de cálcio, seguido do tratamento com solução pós-tratamento, ambos por um minuto, conforme descrito por Ishikama al., em 1994. Os outros três grupos foram tratados com oxalato de potássio a $25 \%$, fluoreto de sódio a $2 \%$ e cloreto de estrôncio a $10 \%$, todos durante três minutos. Tanto as medições de condutividade hidráulica (Figura 5) quanto as observações em microscopia eletrônica de varredura foram avaliadas em intervalos de 0 , 24, 72, 120 e 168 horas após a imersão dos discos em saliva sintética. O tratamento dos discos dentinários pelo método de precipitação de fosfato de cálcio imediatamente reduziu a permeabilidade dentinária para $6 \%$ que permaneceu baixa mesmo após sete dias de imersão em saliva. O oxalato de potássio provocou redução da permeabilidade dentinária para $8 \%$, entretanto, aumentou gradualmente para $39 \%$ ao final de sete dias de imersão em saliva. A utilização do fluoreto de sódio a $2 \%$ e do cloreto de estrôncio a $10 \%$ acarretou no aumento da permeabilidade. As observações em microscopia eletrônica de varredura não mostraram linha demarcatória entre o precipitado de apatita e a dentina intertubular, indicando sua mineralização. Quando o oxalato de potássio foi aplicado, as fotomicrografias revelaram pequenos cristais ocluindo os túbulos dentinários que desapareceram após sete 
dias de imersão em saliva. Para elucidar o mecanismo das mudanças na permeabilidade dentinária na saliva sintética, os precipitados, isto é, a apatita e o oxalato de cálcio, foram imersos num volume fixo de saliva sintética. Observaram uma grande concentração de íons oxalato, indicando dissolução do oxalato de cálcio e desta forma, aumentando a permeabilidade dentinária. Portanto, o tratamento com oxalato de potássio significativamente reduz a hiperestesia dentinária, mas seu efeito tem curta duração. Em contraste, os íons cálcio e fosfato diminuem quando o produto formado pelo método de precipitação é imerso em saliva, indicando uma precipitação de fosfato de cálcio no precipitado de apatita. Os autores concluíram que o método de precipitação de fosfato de cálcio teria um efeito contínuo de redução da permeabilidade dentinária no ambiente oral.

Pashley et al. ${ }^{169}$, em 1996, avaliaram a magnitude e a direção da movimentação do fluido pela dentina in vitro, em resposta a estímulos hidrodinâmicos produzidos clinicamente para detectar a hiperestesia dentinária, e então, relacioná-los com a condutividade hidráulica de cada espécime. A partir desta determinação, consegue-se um denominador comum equivalente à pressão hidrostática requerida para provocar a mesma magnitude de movimentação do fluido. As medições da condutividade hidráulica foram feitas em oito segmentos coronários, repetidas em três espessuras de dentina, empregando-se o dispositivo Flodec (Figura 17) capaz de detectar alterações lineares mínimas do movimento da bolha de ar na solução salina. A área de superfície dentinária foi obtida por intermédio da digitalização de fotografias. Os estímulos hidrodinâmicos utilizados: jatos de ar, água a $56^{\circ} \mathrm{C}$, água a $2^{\circ} \mathrm{C}$, estímulo tátil e osmótico, foram aplicados com a pressão pulpar zero, e as medições feitas com o nível de solução salina no reservatório $25 \mathrm{~cm}$ acima da câmara pulpar. Em dentina superficial condicionada, que simula a dentina hiperestésica, a movimentação do fluido ocorreu em ordem decrescente para os estímulos: calor, frio, jatos de ar, osmótico e tátil. A mesma ordem de estímulos foi válida após a equivalência hidrodinâmica dos valores. 


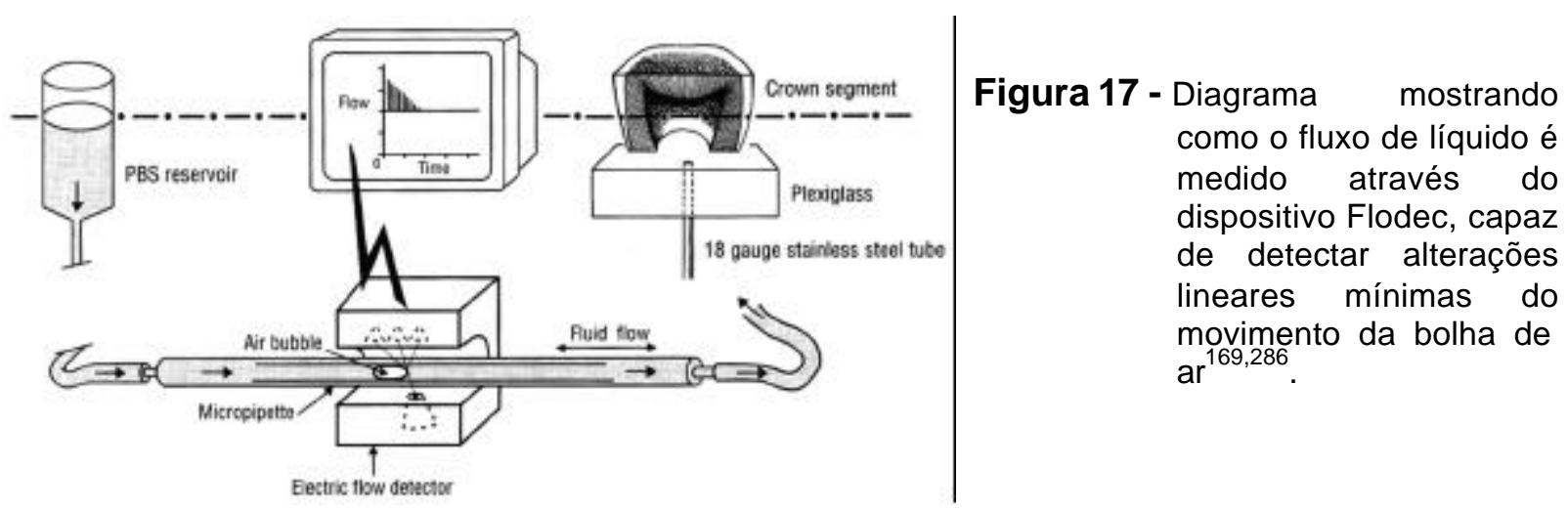

Considerando a hipótese de que a deposição de imunoglobulinas do fluido dentinário nas paredes dos túbulos possa reduzir a permeabilidade, Hahn e Overton $^{85}$, em 1997, pensaram em examinar os efeitos dessas moléculas na permeabilidade dentinária utilizando o método de filtração. A filtração com $100 \mu \mathrm{g} / \mathrm{ml}$ de $\mathrm{lgG}, 100 \mu \mathrm{g} / \mathrm{ml}$ de $\operatorname{lgA}$ ou $30 \mu \mathrm{g} / \mathrm{ml}$ de IgM, foi executada no sistema ilustrado na Figura 13A através dos segmentos coronários dos terceiros molares, sob pressão constante de $68,9 \mathrm{KPa}$ durante três horas. Foi realizada a análise do conteúdo de imunoglobulina contida na solução coletada da superfície oclusal coronária dos segmentos, bem como o percentual de retenção da imunoglobulina na dentina. Houve um decréscimo de 70 a $80 \%$ na filtração das imunoglobulinas. O percentual de retenção das imunoglobulinas foi significativamente relacionado ao tempo de filtração e a retenção das imunoglobulinas contribuiu para as mudanças significantes da filtração com o tempo. Estes resultados in vitro demonstraram a deposição de imunoglobulinas do fluido dentinário nas paredes dos túbulos com o tempo e, indicando seu potencial no decréscimo da permeabilidade dentinária.

Nos estudos de condutividade hidráulica, duas variáveis importantes não foram claramente estandardizadas, a pressão e o tempo. Portanto, Camps et al. ${ }^{37}$, em 1997, avaliaram o efeito in vitro do emprego de pressões baixas, médias e altas e do tempo de aplicação, na condutividade hidráulica da dentina humana, utilizando um sistema de 
medição em forma de $U$. Os discos de dentina de $0,7 \mathrm{~mm}$ foram imersos em ácido fosfórico a $35 \%$ por 30 segundos e acoplados, com o lado pulpar voltado para a atmosfera, a câmara de filtração sistema que permite $12,56 \mathrm{~mm}^{2}$ de dentina exposta. Realizaram testes variando a pressão de 1,3 KPa até 53,3 KPa e acompanharam a filtração da água através dos discos de dentina a cada dez minutos durante três horas. Os resultados demonstraram que o volume de fluido filtrado aumentou com o tempo e a pressão. As pressões de 13,3; 26,6 e $40 \mathrm{KPa}$, provocaram uma diminuição da filtração e da condutividade hidráulica com o passar do tempo, mas permaneceram constantes para pressões de 1,3 e $53,3 \mathrm{KPa}$. A utilização de pressão baixa de 1,3 KPa, permite a filtração sem alterar o conteúdo intratubular, enquanto que as pressões médias, alteram o conteúdo dos túbulos progressivamente causando alterações nas medidas de condutividade hidráulica com o passar do tempo. A pressão alta de 53,3 KPa parece acumular imediatamente o conteúdo tubular contra a resistências intratubulares, resultando numa condutividade hidráulica baixa.

Num estudo longitudinal realizado em 1998, Zhang et al. ${ }^{286}$, estudaram a habilidade do material, Pain-Free Desensitizer, composto de uma solução aquosa de ácido oxálico a 2,1\% misturada a uma emulsão resinosa, em ocluir túbulos dentinários superficiais e profundos, imediatamente, após um dia, uma semana e um mês da sua aplicação. Os segmentos coronários, preparados a partir de terceiros molares, foram condicionados com ácido fosfórico a $35 \%$ ou com uma pasta de hidroxiapatita e ultra-som. A condutividade hidráulica de cada espécime foi medida com o auxílio do dispositivo Flodec (Figura 17), utilizando uma pressão de $20 \mathrm{~cm} \mathrm{H}_{2} \mathrm{O}$. Após uma aplicação do agente anti-hiperestésico, a condutividade hidráulica foi determinada aos cinco minutos, um dia, uma semana e um mês. Entre os intervalos de tempo, os espécimes foram armazenados numa solução tamponada para simular os efeitos solubilizantes da saliva. Após 30 dias, a espessura da dentina foi reduzida em $1 \mathrm{~mm}$ e os experimentos foram repetidos na dentina profunda. Paralelamente, outros espécimes foram submetidos à microscopia eletrônica de varredura. Os resultados 
mostraram que uma aplicação do material promoveu reduções grandes e imediatas na permeabilidade dentinária sem diferenças estatísticas para ambos os grupos, entretanto, ao longo do tempo a condutividade permaneceu baixa apenas na dentina não condicionada. A aparência microscópica da dentina superficial em ambos os grupos foi de uma superfície coberta por uma camada amorfa de material resinoso cobrindo os túbulos. A dentina profunda e condicionada mostrou túbulos abertos sem evidência de material amorfo e a dentina polida, muitos túbulos permaneceram ocluídos após o tratamento. Não foi observada boa correlação entre os resultados de permeabilidade e os de microscopia. Presumivelmente, a oclusão dos túbulos pelo dessensibilizante seria longo o suficiente, isto é, de um a dois meses, para permitir uma reação físico-química natural e ocluir os túbulos, mantendo a dessensibilização dentinária.

Santiago ${ }^{227}$, em 1999, verificou a influência do tempo pós-aplicação de agentes antihiperestésicos na permeabilidade de discos de dentina. Os agentes anti-hiperestésicos aplicados nos discos de dentina e adaptados no sistema de medição da condutividade hidráulica, sugerido por Pashley e Galloway, em 1985 (Figura 8), foram: Oxa-Gel, solução à base de oxalato de potássio mono-hidratado a $3 \%$, com $\mathrm{pH} 4$; dois produtos experimentais, um, à base de oxalato de potássio mono-hidratado a $6 \%$, com pH 4; e outro, também à base de oxalato de potássio mono-hidratado a $3 \%$, com $\mathrm{pH} 2,5$; agente placebo e água deionizada. As medições foram realizadas após a criação da smear layer com lixas; após o condicionamento da dentina com EDTA $0,5 \mathrm{M}$, durante dois minutos; após os tempos 0,5 , 15 e 30 minutos da aplicação dos agentes; e após o desafio com ácido cítrico durante um minuto. A área de superfície dentinária testada foi de 0,282 e de $0,178 \mathrm{~cm}^{2}$, sob pressão de $703 \mathrm{~cm} \mathrm{H} \mathrm{H}_{2} \mathrm{O}$. Os resultados indicaram que o tempo decorrido após a aplicação do agentes provocou a redução da permeabilidade dentinária para todos os grupos estudados. Os valores obtidos pelos materiais não apresentaram diferenças significantes entre si, o mesmo ocorreu entre o placebo e a água deionizada. Porém, após o desafio ácido, os agentes à 
base de oxalato de potássio mostraram-se resistentes, diferente do placebo e da água. $\mathrm{O}$ sistema de filtração interfere nos resultados em função do tempo, pois houve uma tendência de redução dos valores quando o sistema flui livremente pelos intervalos de tempo testados. Pode-se concluir que todos os agentes estudados, à base de oxalato de potássio, são efetivos na redução da permeabilidade dentinária, independentemente do tempo após a aplicação.

\subsubsection{Estudos do Coeficiente de Permeabilidade, in vitro.}

Sobre difusão Merchant, Livinston e Pashley ${ }^{134}$, em 1977, esclareceram que a maior diferença com a filtração é que durante esta última, nenhuma energia química é dissipada a distância, proporcionando uma concentração química mais elevada disponível para os propósitos terapêuticos. Concluíram que a filtração oferece muitas vantagens sobre a difusão em termos de transferência de agentes terapêuticos através da dentina em direção à polpa. Outro aspecto importante relacionado à difusão e à filtração foi discutido por Pashley e Matthews ${ }^{189}$, em 1993, quando determinaram como a movimentação de fluidos no sentido polpa-esmalte pode modificar a difusão de substâncias potencialmente irritantes para o interior dos túbulos dentinários. Segundo os autores, na presença da smear layer e sob pressão de filtração de $15 \mathrm{~cm} \mathrm{H}_{2} \mathrm{O}$ na direção polpa-esmalte, o fluxo do iodo em direção a polpa reduziu de 10 a $20 \%$, e quando a smear layer é removida, a redução pode ser maior do que $60 \%$. Os resultados esclareceram a importância do equilíbrio entre a difusão em direção à polpa e à filtração no sentido do esmalte no padrão da permeabilidade dos solutos exógenos. Portanto, de acordo com os propósitos deste estudo, a literatura revisada referese, principalmente, à filtração de substâncias através da dentina.

Outhwaite, Livingston e Pashley ${ }^{156}$, em 1976, estudaram os efeitos das modificações na área de superfície, temperatura, espessura e período pós-extração na permeabilidade dentinária ao iodo. Os discos de dentina, foram seccionados de terceiros molares com broca carbide 556 refrigerada, removendo todo esmalte e de formas que fosse 
criado um plano paralelo ao plano oclusal do dente. A porção radicular remanescente foi removida da mesma maneira, paralelamente ao plano estabelecido, em direção ao teto da câmara pulpar. As superfícies oclusal e pulpar foram alisadas com lixa de óxido de silicone. Os discos de dentina com 1,0 $\pm 0,05 \mathrm{~mm}$ de espessura, foram adaptados em uma câmara de medição, a mesma sugerida por Outhwaite, McKenzie e Pashley ${ }^{157}$, em 1974, e a permeabilidade do iodo radioativo foi medida do lado do esmalte para o lado pulpar dos discos. Os valores de permeabilidade foram calculados utilizando a equação de Fick. Observaram que dobrando a área de superfície, dobrou a quantidade de iodo que permeava a dentina por unidade de tempo, sendo que a estas duas variáveis dependeram de quão próximo da câmara pulpar foi preparado o disco de dentina. Determinaram que a redução da espessura da dentina a partir do lado do esmalte dos discos resultou num aumento maior da permeabilidade do que reduções do lado pulpar e que aumentando a temperatura da dentina em $10^{\circ} \mathrm{C}$ quase dobrou a permeabilidade ao iodo. $\mathrm{E}$ ainda, que o período pósextração teve pouco efeito sob a permeabilidade dentinária medida após três a quatro semanas in vitro.

Merchant, Livingston e Pashley ${ }^{134}$, em 1977, compararam o índice de permeabilidade do iodo através da dentina por difusão e por filtração. Foram preparados discos de dentina, como descrito por Outhwaite, Livingston e Pashley, em 1976, e adaptados na câmara de medição da permeabilidade proposta por Outhwaite, McKenzie e Pashley ${ }^{157}$ e modificada. Antes do condicionamento de ambos os lados do disco de dentina com ácido cítrico a 50\% durante dois minutos, o índice de permeabilidade relativa ao iodo por filtração dobrou em relação ao obtido por difusão. Após o condicionamento ácido, a filtração produziu um aumento de 32 vezes em permeabilidade. O condicionamento ácido, que remove os resíduos oclusores, facilitou mais a filtração do que a difusão. Os resultados indicaram que a filtração através da dentina pode proporcionar vantagens terapêuticas significantes sobre a difusão. 
A relação existente entre os coeficientes de permeabilidade dentinária e as dimensões moleculares de diferentes substâncias foi uma preocupação de Pashley e Livingston ${ }^{185}$, em 1978. Prepararam então, os discos de dentina que foram adaptados na câmara preconizada por Outhwaite, McKenzie e Pashley ${ }^{157}$, em 1974, tendo uma solução radioativa no reservatório superior, acima do disco, conferindo a pressão hidrostática de 0,3 $\mathrm{cm} \mathrm{H}_{2} \mathrm{O}$ no sentido esmalte-polpa. Os cálculos de permeabilidade, feitos com base na Lei de Fick, demonstraram um aumento de 19 vezes no diâmetro molecular, isto é, de 1,9 da água para $37 \AA$ da albumina, resultando num decréscimo de 100 vezes nos coeficientes de permeabilidade. Após o condicionamento da dentina, obteve-se um aumento de quatro vezes na permeabilidade da água e nove vezes para a albumina. Tanto o flúor quanto a clorexidina tiveram o coeficiente de permeabilidade muito reduzido em relação ao seu peso e tamanho molecular, sugerindo que se aderem à dentina. Os autores concluíram que a relação permeabilidade/tamanho molecular é verdadeira e que a permeabilidade da dentina é determinada, em parte, pela natureza da superfície dentinária.

Os efeitos das mudanças na natureza das superfícies dentinárias no coeficiente de permeabilidade da água e da albumina foram determinados in vitro por Pashley ${ }^{174}$ et al., em 1978. Os discos de dentina foram posicionados na câmara de medição de permeabilidade preconizada por Outhwaite, McKenzie e Pashley ${ }^{157}$ e modificada, onde o fluxo difusional foi medido na direção oclusal para pulpar. O exame em M.E.V. dos discos tratados com oxalato mostrou debris cristalinos na superfície e a $20 \mu \mathrm{m}$ em profundidade. A água, de tamanho molecular reduzido em relação à albumina, mostrou índice de permeabilidade superior à albumina. A superfície condicionada promoveu um aumento significante de fluxo, e o tratamento com oxalato provocou uma significante diminuição. Os dados mostraram que o tratamento da dentina condicionada com oxalato de monopotássio monohidrogenado a $3 \%$, pode reverter o aumento da área de superfície difusional avaliada por difusão a níveis 
próximos ao controle, por intermédio da reoclusão das aberturas dentinárias tubulares com cristais insolúveis.

A fim de quantificar os efeitos da smear layer na difusão de substâncias através da dentina com ou sem a aplicação da pressão pulpar fisiológica, Pashley e Matthews ${ }^{189}$, em 1993, conduziram experimentos in vitro determinando como a movimentação de fluidos de dentro para fora da dentina pode modificar a difusão de substâncias potencialmente irritantes para o interior dos túbulos dentinários. Através da utilização de discos de dentina posicionados na câmara sugerida anteriormente por Pashley e Galloway ${ }^{181}$ modificada, a difusão do iodo foi medida em várias condições. Os resultados mostraram que na presença da smear layer, a aplicação da pressão de filtração de $15 \mathrm{~cm} \mathrm{H} \mathrm{H}_{2} \mathrm{O}$ na direção polpa-esmalte reduziu o fluxo do iodo em direção a polpa de 10 a $20 \%$. Quando a smear layer foi removida pelo condicionamento ácido, a mesma pressão reduziu o fluxo mais do que $60 \%$, dependendo da espessura e da condutividade hidráulica dos espécimes. Os resultados demonstraram a importância do equilíbrio entre a difusão para o interior e o movimento do fluxo para o exterior no padrão da permeabilidade dos solutos exógenos.

O objetivo do experimento de Camps $^{35}$ et al., em 1996, foi avaliar a influência da simulação de uma pressão pulpar pulsátil, na difusão do cloreto de sódio através da dentina, in vitro. A condutividade hidráulica foi determinada nos discos de dentina seguida pela avaliação da difusão do cloreto de sódio. A área oclusal da superfície exposta de $0,2 \mathrm{~cm}^{2}$ do disco ficou em contato com a solução de cloreto de sódio, e o pulpar conectado ao sistema preenchido com água deionizada, onde foi aplicada a pressão hidrostática de $406 \mathrm{~cm} \mathrm{H}_{2} \mathrm{O}$. O tempo necessário para atingir o equilíbrio e quantificar o cloreto de sódio que se difundiu através do disco de dentina foi sucessivamente medido, sob três condições: sem simular a pressão, com pressão estática de 1,5 Kpa, e com pressão pulsátil variando de 1,2 a 1,8 KPa. Para a simulação da pressão pulsátil adaptou-se na câmara de medição, uma bomba e um motor. As soluções foram trocadas a cada medição para restabelecer o gradiente de 
concentração inicial e, a água deionizada foi analisada para medir a quantidade de cloreto de sódio que atravessou o disco de dentina nos diferentes períodos de tempo. O tempo requerido para alcançar o equilíbrio foi maior quando a pressão estática foi aplicada, aumentou de 24 para 30 horas. Sob pressão pulsátil, o tempo diminuiu de 24 para 12 horas. A quantidade de cloreto de sódio que se difundiu foi a mesma para todas as condições experimentais.

\subsubsection{Estudos do Coeficiente de Reflexão, in vitro}

Investigações prévias da sensibilidade dentinária utilizando estímulo osmótico mostraram a necessidade de concentrações molares muito altas, de 2 a $6 \mathrm{M}$, para a remoção da dor. Quando a pressão hidrostática foi utilizada, pressões muito menores foram requeridas, indicando que apenas uma fração da pressão osmótica teórica é efetiva para mover o fluido através da dentina. A razão entre a pressão osmótica teórica e a efetiva, denominada coeficiente de reflexão, é uma medida do grau de semipermeabilidade da dentina e pode variar de 0 , caracterizando a completa permeabilidade do soluto, a 1,0, completa impermeabilidade do soluto $^{188}$.

O trabalho de Pashley, Livingston e Whitford ${ }^{188}$, em 1979, utilizou a câmara descrita por Outhwaite, McKenzie e Pashley ${ }^{157}$, em 1974, para investigar o efeito do tamanho molecular no coeficiente de reflexão da dentina. Os resultados mostraram que o condicionamento com ácido cítrico a $50 \%$ durante dois minutos produziu um decréscimo estatisticamente significante de cinco a nove vezes no coeficiente de reflexão, ou seja, uma maior permeabilidade do soluto, enquanto que o tratamento com oxalato de monopotássio mono-hidrogenado a $3 \%$ restaurou-o aos níveis da dentina abrasionada ou maior. Pashley e Whitford ${ }^{197}$, em 1980, repetindo a metodologia realizada no ano anterior, interpretaram a permeabilidade da dentina por meio do coeficiente de reflexão da uréia, de vários sais e de açúcares. Os dados indicaram que a pressão osmótica efetiva exercida pelos solutos 
concentrados de baixo peso molecular é uma pequena fração da pressão osmótica teórica e que a utilização do coeficiente de reflexão permite a estimativa da pressão osmótica efetiva de soluções de substâncias de baixo peso molecular. Os baixos coeficientes de reflexão indicam que a dentina foi muito permeável às substâncias estudadas, ou seja, não faz boa discriminação entre água e solutos de baixo peso molecular. O coeficiente de reflexão formaliza o grau de semipermeabilidade da dentina.

2.12.2. Métodos Qualitativos de Permeabilidade Dentinária (Microscopia Eletrônica de Varredura, Microanálise de Raios X, Difração de Raios X)

Ao estudar os diferentes aspectos relacionados à permeabilidade dentinária, comumente os autores têm associado o método de análise quantitativa de condutividade hidráulica com outros métodos de avaliação qualitativos e/ou quantitativos, envolvendo, especialmente, a microscopia eletrônica de varredura. Nos experimentos de Pashley e seus colaboradores, um dos autores que mais publicou sobre este assunto, freqüentemente se encontram as medições de condutividade hidráulica associadas às imagens de microscopia eletrônica de varredura ${ }^{60,63,81,135,174,181,183,184,190,200,213,253,237,239,286}$. Também outros autores utilizaram-se desta associação ${ }^{141,144,246,248,249}$. A microscopia eletrônica de varredura pode ser associada à análise de imagens para avaliar quantitativamente os túbulos dentinários após o tratamento com agentes anti-hiperestésicos, ou ainda, analisar os efeitos da smear layer na obstrução dos túbulos ${ }^{102,221 .}$ A condutividade hidráulica e a microscopia eletrônica de varredura podem ser estudadas complementando-se, ainda, com outros métodos de análise, como a microanálise de raios $X^{103,104,111,124,285,250}$, a difração de raios $X^{103,141,248,250,268}$ e até mesmo análises histológicas ${ }^{108,193}$.

Referindo-se estritamente à análise da permeabilidade dentinária através de métodos que utilizam-se da microscopia eletrônica de varredura, os autores consideram que a microanálise de raios $X$ pode ser aplicada para avaliar a captação de compostos pela dentina $2,3,6,47,51,114$, as características da smear $l a y e r^{58}$, e também para caracterizar a 
natureza dos depósitos na superfície $86,104,111,124,250,285$. Outros investigadores têm utilizado este tipo de microscopia para avaliar a morfologia dentinária ou as características superficiais após a aplicação de agentes anti-hiperestésicos ${ }^{103,158,280,282,283,285}$.

Nas microanálises de raios $X$ não é surpresa encontrar picos elevados de carbono, em espécimes montados em porta-amostras de alumínio ou latão, quando cobertos com aquele elemento no momento da preparação. Também podem ser detectados ouro, paládio, cálcio, fósforo e oxigênio devido à penetração do feixe de elétrons nos discos de dentina, inevitável pela necessidade de produzir um espécime condutivo. Isto aumenta o problema de diferenciação de elementos endógenos e exógenos, como o cálcio, fósforo, oxigênio e carbono. A interpretação do espectro pode também ser dificultada se houver a sobreposição dos picos, pois um pico pequeno pode não aparecer se não houver uma grande diferença de percentagem entre os dois elementos ${ }^{72}$. Também Ling ${ }^{124}$ et al., em 1997, consideram que a dificuldade de interpretação das microanálises de raios $X$, ocorre devido às falhas na detecção de componentes relacionadas com as pequenas quantidades presentes ou aos agentes mascaradores.

$\mathrm{Na}$ tentativa de padronizar os experimentos que avaliam in vitro o potencial dos agentes anti-hiperestésicos na oclusão dos túbulos dentinários, Absi, Addy, $\mathbf{A d a m s}^{3}$, em 1995, sugeriram a utilização dos discos de dentina, previamente propostos para medições de permeabilidade, como um método usual de estudo em microscopia de varredura. Outra interessante preocupação foi exposta por $\operatorname{Ling}^{124}$ et al. e Mordan, Barber e Gillam ${ }^{146}$, ambos em 1997, quando propuseram a utilização de um mesmo disco de dentina para fornecer ambas as superfícies experimental e correspondentes controle. Segundo Mordan, Barber e Gillam ${ }^{146}$, haverá uma correlação mais fiel da aparência morfológica entre os espécimes teste e controle se as áreas estudadas forem próximas umas das outras e da área de fratura, pois a extensão tanto do condicionamento como dos sulcos da superfície serão similares e a orientação, diâmetro e extensão do condicionamento nos túbulos serão 
também comparáveis. A fim de minimizar as diferenças topográficas, também propuseram que a área de exame estivesse localizada acima dos cornos pulpares, pois os túbulos neste local possuem maior diâmetro do que os da periferia do disco dentinário e estão orientados perpendicularmente à superfície dentinária, fornecendo uma excelente área de teste.

Segundo Mordan, Barber e Gillam ${ }^{146}$, e também Ling ${ }^{124}$ et al., ambos em 1997, em estudos prévios os investigadores analisaram os efeitos da oclusão tubular dos agentes antihiperestésicos pela observação dos discos de dentina em microscopia eletrônica de varredura proporcionando apenas termos descritivos, como por exemplo, oclusão completa ou parcial dos túbulos dentinários. Outros descreveram seus resultados com símbolos, como,,++++++ , etc. ${ }^{3}$ ou providenciaram índices baseados na percentagem de túbulos ocluídos ${ }^{104,114,221}$. Em essência, apesar dos investigadores chamarem seus métodos de quantitativos, na realidade, são principalmente estudos descritivos ou qualitativos. O estudo de Ip $^{102}$ et al., em 1997, por intermédio da análise das imagens fornecidas pela microscopia eletrônica de varredura refinou a metodologia que envolve a análise das características superficiais da dentina tratada com agentes anti-hiperestésicos. As comparações das superfícies dos discos dentinários indicaram diferenças no número de túbulos, área de túbulos abertos, largura do lúmen dos túbulos e a percentagem de áreas abertas com relação ao campo de observação pode ser avaliada quantitativamente.

Outra observação interessante foi feita por Ling $^{124}$ et al., em 1997, quando observaram que os agentes anti-hiperestésicos previamente analisados como tendo efeito limitado ou pouco efeito na superfície dentinária proporcionaram redução significante na largura e área do túbulo quando analisados através da análise de imagens. Isto parece suportar as observações de Gillam, Mordan e Newman ${ }^{72}$, em 1997, de que apenas a análise descritiva ou qualitativa da superfície dentinária pode ser insuficiente para a avaliação das propriedades de oclusão tubular dos agentes anti-hiperestésicos. 


\subsubsection{Estudos Laboratoriais de Microscopia Eletrônica de Varredura}

Considerando que a terapia para dentina hiperestésica é produzir uma smear layer artificial para fechar os túbulos dentinários abertos, Mongiorgi ${ }^{142,143}$ et al., em 1991, realizaram dois experimentos, avaliando através de microscopia eletrônica de varredura a morfologia da smear layer após diferentes tratamentos químicos. O tratamento com o ácido ortofosfórico removeu a smear layer e abriu os túbulos dentinários. O tratamento com solução de oxalato de potássio hidrogenado a 30\% em água produziu uma camada de cristais grandes e irregulares que cobriram a superfície dentinária, fechando parcialmente os túbulos dentinários. A solução de oxalato de potássio hidrogenado a $30 \%$ em solução de colágeno, produziu uma camada uniforme de resíduos dentinários com alguns cristais visíveis, sendo os túbulos dentinários completamente cobertos por uma mistura de cristais de oxalato e colágeno. Sendo as soluções de oxalato capazes de produzir uma camada de cristais, os autores sugeriram que a permeabilidade e a hiperestesia dentinária possam ser reduzidas por esse tratamento.

Zaimoglu e Aydin ${ }^{285}$, em 1992, estudaram as propriedades de agentes antihiperestésicos que promovem oclusão dos túbulos dentinários e a eficiência da interação desses agentes com a smear layer previamente à cimentação de coroas com fosfato de zinco, empregando microscopia eletrônica de varredura e microanálise de raios $\mathrm{X}$ por dispersão de energia. Os tratamentos anti-hiperestésicos utilizados na dentina foram: brunidura, verniz cavitário, hidróxido de cálcio e fluoreto de sódio. Concluíram que a smear layer não protege contra a penetração do cimento de bsfato de zinco, enquanto que o verniz cavitário previne a formação dos smear plugs, mas diminui a hiperestesia dentinária. O mesmo ocorre com os tratamentos com hidróxido de cálcio e fluoretos, e não afetam adversamente a retenção. Quanto à brunidura, além de provocar o acúmulo de microorganismos nos túbulos, o aumento dos plugs no interior dos túbulos provoca dor 
relacionada com o mecanismo hidrodinâmico. A smear layer e os smear plugs eram, basicamente, compostos de cálcio e fósforo, os principais componentes da dentina.

Pereira e Nicolau ${ }^{207}$, em 1993, estudaram em microscopia eletrônica de varredura, o efeito das formulações à base de oxalato de potássio sobre a dentina previamente condicionada com ácido fosfórico a $37 \%$ e sobre a smear layer. Os espécimes foram tratados por dois minutos com soluções e géis a base oxalato de potássio a $3 \%$, variando o pH de 2 a 4 conforme ajustado com ácido clorídrico ou ácido fosfórico. Os autores não observaram a formação de cristais visíveis na embocadura dos túbulos, nem depositados na superfície dentinária desmineralizada. Quando aplicado sobre a smear layer, os autores observaram a remoção parcial dessa camada, a qual passou a apresentar aspecto granuloso parecida com depósitos minerais. Concluíram que o oxalato de potássio, na forma em que foi empregado, tem reduzido potencial de reação com a dentina desmineralizada.

A fim de efetivamente reduzir a hiperestesia dentinária, Knight ${ }^{114}$ et al., em 1993, examinaram em microscopia eletrônica de varredura o efeito de vários procedimentos químicos e mecânicos na obliteração dos túbulos dentinários da porção cervical de prémolares contendo túbulos dentinários abertos. O tratamento mecânico consistiu da instrumentação contínua com curetas e instrumentos de várias naturezas. O tratamento químico incluiu resina fotopolimerizável e ingredientes obliterativos ativos como os fluoretos de sódio, estanhoso e de hidrogênio, oxalato de potássio a 3\%, glicerina, oxalato férrico, e nitrato de potássio. Meia parte dos espécimes quimicamente tratados foram jateados com água para avaliar a retenção dos agentes obliterativos. Os resultados revelaram que entre os tratamentos mecânicos, a obliteração tubular mais consistente e completa foi obtida pela cureta. Os instrumentos plásticos não tiveram efeito tubular obliterativo. Entre os procedimentos químicos, a resina fotopolimerizada resultou na mais completa obliteração dos túbulos, enquanto que os agentes fluoretados e a glicerina não tiveram efeito. O oxalato de potássio deixou considerável número de cristais sobre a superfície dentinária, mas não 
obliterou os túbulos efetivamente e não foi suficientemente resistente ao jato de água. Portanto, pode-se supor que a combinação da instrumentação com cureta seguida da aplicação de resina, pode ser um método racional de tratamento de superfícies dentinárias hiperestésicas.

Dragolich, Pashley e Brennan ${ }^{56}$, em 1993, examinaram a habilidade do oxalato de ferro em ocluir os túbulos dentinários radiculares com cristais, tanto na presença da smear layer quanto após a sua remoção com diferentes soluções. O oxalato de ferro a $6 \%, \mathrm{pH}$ 1,01, foi aplicado nos cortes dentinários e examinados em microscopia eletrônica de varredura, a fim de fazer a contagem do número de cristais grandes e pequenos. Os resultados indicaram que com relação a remoção da smear layer, o ácido cítrico $140 \%$ (pH 0,22) por três minutos foi o mais efetivo, seguido pelo ácido cítrico a $20 \%(\mathrm{pH} 1,0)$ por três minutos e EDTA a $0,5 \mathrm{M}(\mathrm{pH} 7,4)$ por dois minutos. Porém, na presença da smear layer, houve aumento do número e da variabilidade de cristais que se formaram após a aplicação do oxalato de ferro na dentina radicular. Portanto, nenhum pré-tratamento químico de dentina radicular está indicado previamente a aplicação do oxalato de ferro no tratamento da hiperestesia radicular.

Gillam $^{70}$ et al., em 1996, investigaram os efeitos do potencial de oclusão dos túbulos de diferentes agentes anti-hiperestésicos, um à base de oxalato férrico, dois sistemas adesivos e dois à base de oxalato de potássio. A análise qualitativa em microscopia eletrônica de varredura mostrou que o produto à base de oxalato férrico, Sensodyne Sealant, e os agentes fotopolimerizáveis, All-Bond 2 e o One-Step, foram mais efetivos que os à base de oxalato de potássio, Butler Protect e Oxa-Gel, tanto na cobertura como na oclusão tubular. Os resultados indicaram que todos produziram alguma oclusão tubular, apesar dos níveis de cobertura superficial e oclusão ter variado entre os produtos. Entretanto, a avaliação dos discos de dentina fraturados demonstrou que todos os agentes penetraram nos túbulos em diferentes graus. 
A fim de investigar a relação existente entre hiperestesia dentinária e agentes com potencial para ocluir túbulos dentinários, Mordan, Barber e Gillam ${ }^{146}$, em 1997, experimentaram áreas adjacentes do disco de dentina fraturado, permitindo a correlação entre as superfícies dentinárias controle e experimental. Antes da aplicação dos agentes anti-hiperestésicos, a análise em microscopia eletrônica revelou as características dos tratamentos superficiais prévios, sendo observada nas superfícies que não receberam tratamento, uma smear layer típica. Nas superfícies dentinárias tratadas com ultra-som e água destilada permaneceram partículas de resíduos e, após o condicionamento com ácido cítrico, a smear layer foi removida e os túbulos ficaram claramente visíveis. Os agentes antihiperestésicos aplicados foram o Sensodyne Sealant e o Butler Protect. Após a aplicação do Sensodyne, notou-se um nível variável de deposição na superfície dentinária, e o Butler Protect, proporcionou uma deposição cristalina tanto na superfície quanto dentro dos túbulos após múltiplas aplicações. Os autores concluem que o disco de dentina proporciona um sistema adequado para experimentos in vitro do potencial dos agentes para o tratamento da hiperestesia dentinária.

A avaliação qualitativa em microscopia eletrônica de varredura e a microanálise radiográfica levou Ling ${ }^{124}$ et al., em 1997, a examinar o grau e a composição dos depósitos deixados por vários agentes anti-hiperestésicos na superfície dentinária. Os discos foram fraturados após a remoção da smear layer, sendo uma parte dos espécimes imersa em água destilada e outra, mantida sob rotação em saliva sobrenadante por seis horas. Foram aplicados agentes anti-hiperestésicos de diferentes formulações: os de uso profissional, um à base de oxalato férrico, integrante ativo do Sensodyne Sealant, outro gel de fluoreto estanhoso a $0,4 \%$ e o Butler Protect, à base de oxalato de potássio; e os utilizados pelo paciente, do tipo pasta dental e enxaguatório bucal. Os espécimes foram armazenados em saliva e/ou dessecados, e então estudados no microscópio. Os resultados indicaram que o Sensodyne Sealant depositou estruturas de forma arredondada e/ou parecidas com couve- 
flor, ocluindo quase totalmente os orifícios tubulares e, foi superior ao Butler Protect, cujos depósitos foram esparsos apesar de localizados ao redor das aberturas tubulares (Figura 18). O Colgate Fluorigard Gel não produziu efeito na superfície dentinária. As pastas dentais e enxaguatórios bucais, ambos os componentes abrasivos à base de sílica e cálcio, foram observados na superfície e dentro dos túbulos, indicando certo potencial terapêutico destes dois componentes. Este estudo também demonstrou não haver efeitos visíveis quando os espécimes foram deixados em água destilada ou em saliva.

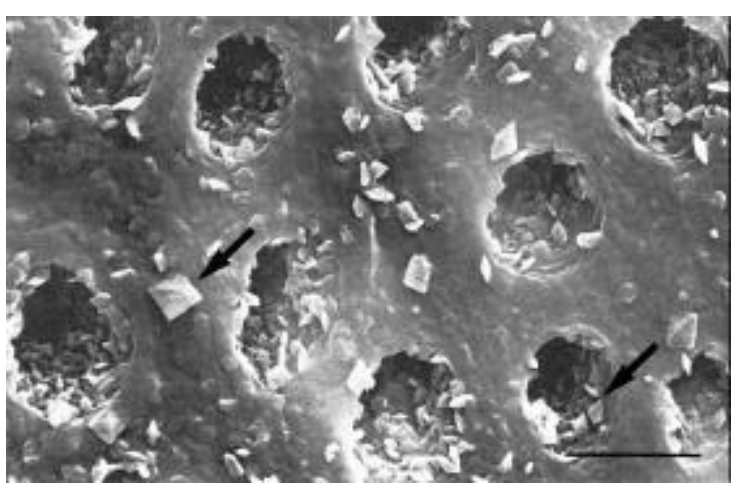

Figura 18 - Fotomicrografia da superficie dentinária após 20 aplicações do Butler Protect. Nota-se muitos cristais na superfície e no interior dos túbulos ${ }^{146}$.

Jain $^{104}$ et al., em 1997, avaliaram o efeito de agentes anti-hiperestésicos na oclusão dos túbulos dentinários, as modificações na composição química da superfície dentinária e o efeito da saliva e escovação nestes agentes. Os agentes estudados foram: Sensoyne Dentin Desensitizer, à base de oxalato de ferro a 6\%; Therma-Trol Desensitizer Gel, à base de oxalato de potássio; Gluma Dentin Desensitizer, à base de glutaraldeído e HEMA; e All Bond DS. Os discos de dentina, obtidos de pré-molares e molares, foram divididos em grupos, sendo metade de cada grupo de discos tratados com os agentes anti-hiperestésicos, observados em microscopia eletrônica de varredura e submetidos à análise de dispersão de raios X. Outra metade dos espécimes de cada grupo, após serem tratados com os agentes, foram imersos em saliva artificial, submetidos à escovação simulada equivalente a três semanas de escovação normal e, então, analisados. Os resultados mostraram que o Sensodyne exibiu maior quantidade de oclusão dos túbulos entre os espécimes que não 
receberam escovação, seguidos de Therma-Trol, Gluma e All Bond. A escovação aumentou a oclusão dos túbulos em todos os casos, exceto para o Sensodyne. Foi evidente a presença de cristais de oxalato de cálcio ocluindo quase completamente os túbulos da superfície dentinária quando o Therma-Trol foi utilizado, entretanto sem qualquer oclusão subsuperficial. Os autores concluíram que após a escovação e imersão em saliva, a oclusão tubular na maioria dos casos aumentou ou permaneceu a mesma, mesmo após os cristais de oxalato e a camada de primer resinoso serem lavados da superfície (Figura 19).
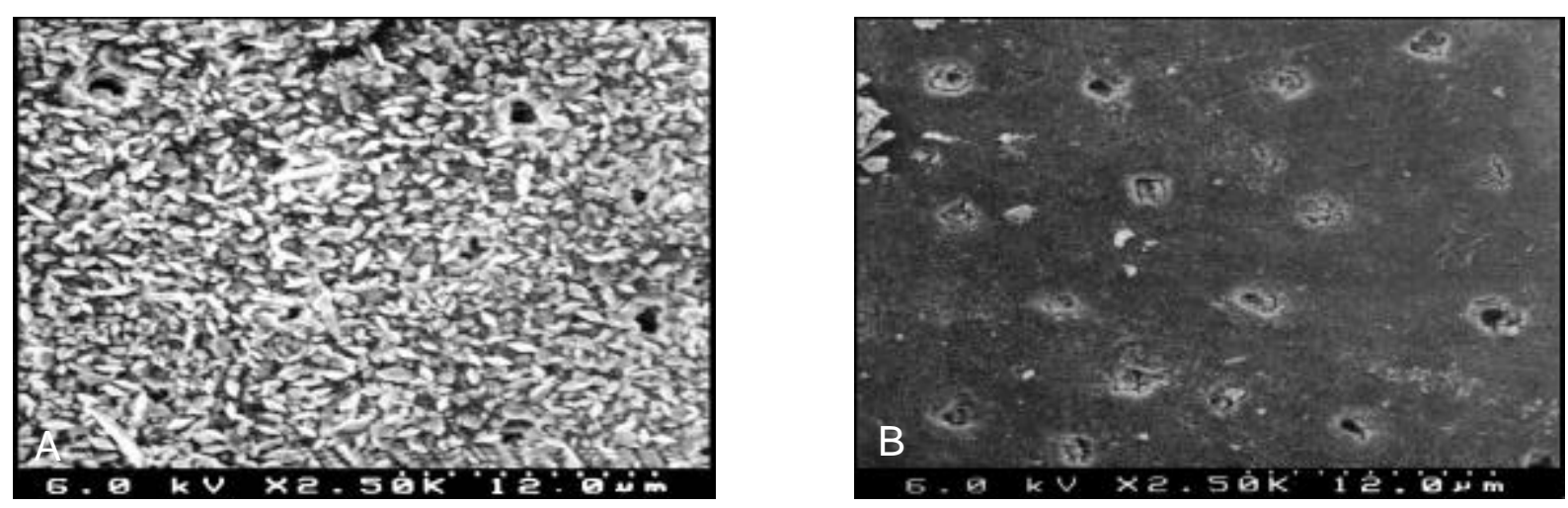

Figura 19 - A - Dentina tratada com Therma-Trol (solução de oxalato de potássio); B - Dentina tratada com Therma-Trol, imersa em saliva artificial e submetida a escovação ${ }^{104}$.

A fim de estabelecer um sistema reprodutível e fidedigno para avaliar a efetividade dos agentes anti-hiperestésicos, Ip $^{102}$ et al., em 1997, quantificaram a oclusão tubular de discos dentinários utilizando a análise de imagens. As imagens de microscopia eletrônica de varredura foram capturadas da região central dos discos de dentina tratados com Butler Protect, Gel-Kam e Sensodyne Sealant, para medições do número dos túbulos, largura do lúmen tubular, área de túbulos abertos, e proporção dos túbulos abertos por área do campo. As imagens foram analisadas com o sistema de análise Quantimet 520 da Leica e os dados analisados no programa Excel. As diferenças após as comparações com o grupo controle indicaram que todas as variáveis podem ser mensuradas quantitativamente e todos os 
agentes anti-hiperestésicos mostraram diferença estatística. Os autores concluíram que o sistema de microscopia eletrônica associado à análise de imagens é fiel e reprodutível na análise dos efeitos superficiais de agentes anti-hiperestésicos utilizando discos de dentina.

Outra informação importante foi fornecida por Yamamoto ${ }^{277}$ et al., em 1996, após o tratamento combinado da dentina de cães com as soluções de oxalato, a 30 e a $3 \%$, de que a precipitação dos cristais de oxalato de potássio in vivo pode ocorrer não apenas na superfície dentinária, mas também nos túbulos dentinários, pois encontraram cristais localizados a $100 \mu \mathrm{m}$ da superfície, no interior dos túbulos dentinários. 
Proposição 


\section{Proposição}

Este trabalho teve o objetivo de estudar in vitro, quantitativa e qualitativamente, o efeito de agentes anti-hiperestésicos na permeabilidade da dentina. Dessa forma, esse estudo procurou:

1. determinar, por intermédio de ensaios de condutividade hidráulica, o padrão de obstrução da dentina proporcionado por três agentes anti-hiperestésicos derivados do oxalato de potássio e por um gel fluoretado, sob cinco formas de pré-tratamento superficial, assim como sua resistência à desobstrução após o desafio ácido;

2. verificar, por meio de microscopia eletrônica de varredura, o padrão de deposição cristalina extra e intracanalicular dos quatro agentes anti-hiperestésicos aplicados sob o prétratamento superficial de melhor desempenho no ensaio de condutividade hidráulica, e também determinar a tendência ao deslocamento dos depósitos cristalinos após o desafio ácido;

3. identificar qualitativa e semiquantitativamente, por meio da microanálise de raios $\mathrm{X}$, os elementos químicos que compõem os cristais formados pela ação dos agentes antihiperestésicos na dentina aplicados sob o pré-tratamento superficial de melhor desempenho no ensaio de condutividade hidráulica;

4. reconhecer, por meio da difração de raios $X$, os compostos cristalinos formados na superfície dentinária após o tratamento da dentina com os agentes anti-hiperestésicos aplicados sob o pré-tratamento superficial de melhor desempenho no ensaio de condutividade hidráulica. 


\section{Material e Métodos}




\section{Material e Métodos}

\subsection{Ensaios de Condutividade Hidráulica}

\subsubsection{Seleção dos Dentes e Obtenção dos Espécimes}

Foram selecionados 200 terceiros molares humanos hígidos, de preferência não irrompidos, extraídos de pacientes jovens e armazenados com solução de timol a 0,1 \% ${ }^{1}$ em água deionizada, a aproximadamente $4^{\circ} \mathrm{C}$, desde a extração até o momento da obtenção dos espécimes, o que ocorreu dentro de um mês.

Os dentes extraídos, livres de remanescentes de material orgânico circunjacente, foram fixados com cera pegajosa aplicada na superfície oclusal da coroa, em uma base de resina $^{2}$ (Figura 20A) e acoplados na matriz metálica da máquina de corte ISOMET $^{3}$. As raízes foram removidas através de um corte ligeiramente acima da junção amelocementária e paralelamente à face oclusal, a uma altura correspondente ao teto da câmara pulpar (Figura 20B). Uma segunda seção, paralela à primeira, removeu o esmalte oclusal, permitindo a obtenção de discos de aproximadamente 1,5 mm de espessura (Figura 20C). Os cortes foram feitos com disco diamantado ${ }^{4}$ de $102,0 \mathrm{~mm}$ de diâmetro e $0,3 \mathrm{~mm}$ de espessura, acoplado à máquina de corte, refrigerado com água e girando a uma velocidade de $300 \mathrm{rpm}$ (Figura 20D). Os discos assim obtidos representavam espécimes exclusivamente de dentina na sua porção central, correspondentes à região situada entre as projeções das fissuras oclusais e o prolongamento dos cornos pulpares (Figura 20E).

\footnotetext{
${ }^{1}$ Merck, Darmstadt, Germany.

${ }^{2}$ Resina T-208, Redifibra Comércio de Produtos para Fiberglass Ltda., São Paulo, Brasil.

${ }^{3}$ Extec Corporation, Labcut 1010, USA.

${ }^{4}$ Extec Corporation, XL-12205, USA.
} 

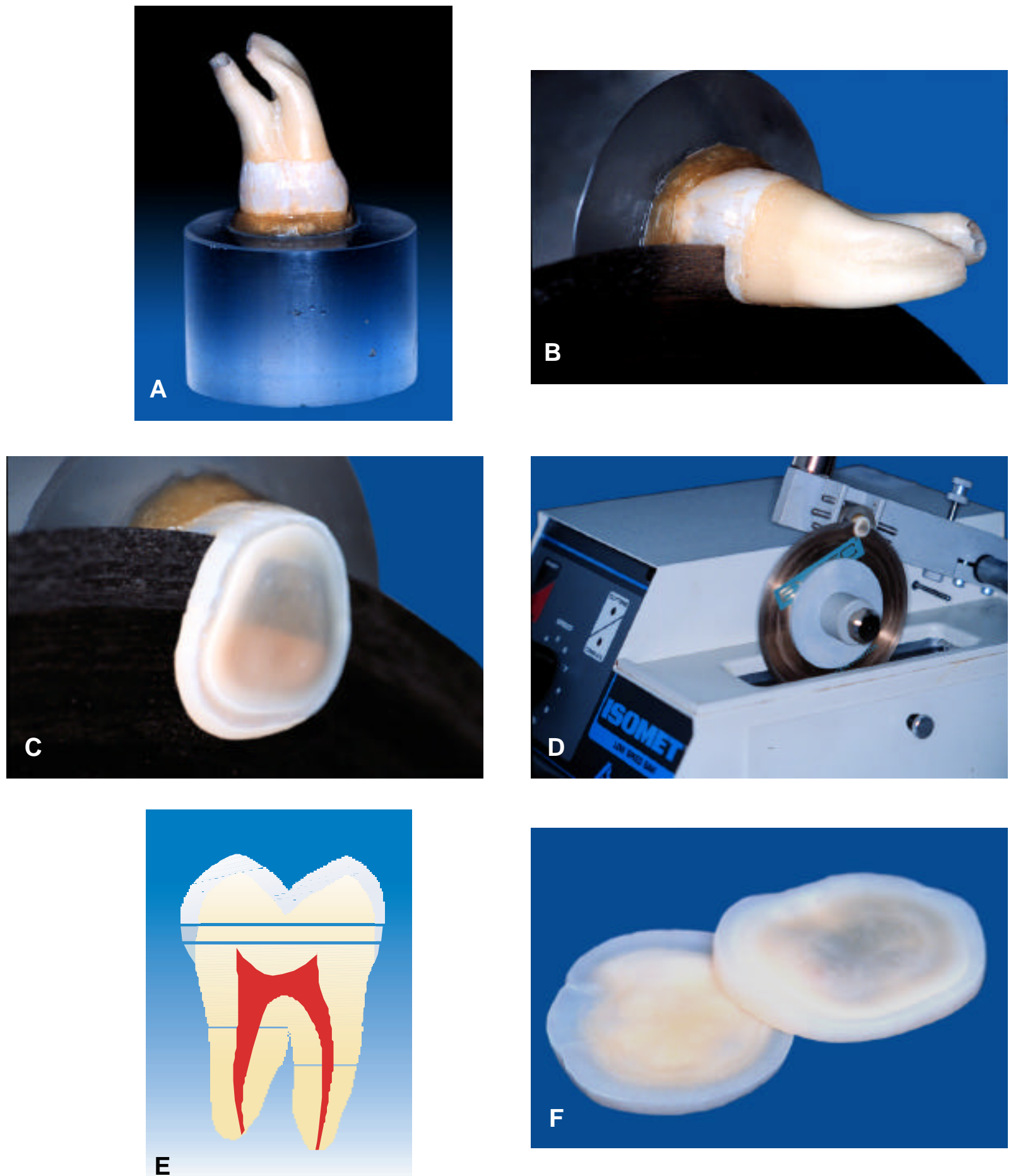

Figura 20 - A - Terceiro molar extraído, fixado na base de resina, pronto para ser acoplado à máquina de corte; $\mathbf{B}$ - Remoção da porção radicular através de um corte aproximadamente na altura do teto da câmara pulpar; C - Corte paralelo ao primeiro, removendo o esmalte oclusal para a obtenção dos discos de dentina; D - Máquina de corte ISOMET utilizada para a confecção dos discos de dentina; E-Diagrama mostrando a localização aproximada do disco de dentina na porção coronária do dente. Notar sua posição imediatamente acima dos cornos pulpares; F - Discos de dentina após o acabamento das superfícies, com aproximadamente $1 \mathrm{~mm}$ de espessura, livres de remanescentes de esmalte e de cornos pulpares. 
Os discos foram submetidos a um desgaste complementar para regularização e acabamento de suas superfícies coronária e pulpar, com lixas de carbeto de silício $^{5}$ de granulação 400 e 600 girando sobre uma politriz ${ }^{6}$, sob água corrente e pressão digital, a uma velocidade de $125 \mathrm{rpm}$. As superfícies dentinárias foram lixadas até que estivessem livres de remanescentes do esmalte coronário e sem qualquer evidência de cornos pulpares, examinadas sob magnificação de 30 vezes e luz refletida ${ }^{7}$, e com uma espessura média de 0,97 $\pm 0,08 \mathrm{~mm}$, confirmada com um paquímetro eletrônico digital ${ }^{8}$ (Figura 20F)

Os espécimes foram mantidos em água deionizada a $10^{\circ} \mathrm{C}$, durante aproximadamente uma semana, até o momento da realização dos ensaios.

\subsubsection{Sistema de Medição da Condutividade Hidráulica}

Os ensaios quantitativos de condutividade hidráulica, para serem realizados, necessitaram do sistema sugerido por Pashley e Galloway, em 1985, especialmente desenvolvido para a medição da permeabilidade dentinária, que encontra-se esquematizado na Figura 21. Esse sistema é composto por dispositivos que se interligam através de capilares de polietileno, em cujas extremidades se destacam um cilindro de nitrogênio, uma câmara de pressão e outra de filtração onde são adaptados os discos de dentina.

\footnotetext{
${ }^{5}$ Buehler Ltda.,Illinois, USA.

${ }^{6}$ Fortel Indústria e Comércio Ltda., Brasil.

${ }^{7}$ Lupa Estereoscópica, Meiji Techno Co. Ltda., Tokyo, Japan.

${ }^{8}$ Starrett Indústria e Comércio Ltda., São Paulo, Brasil.
} 


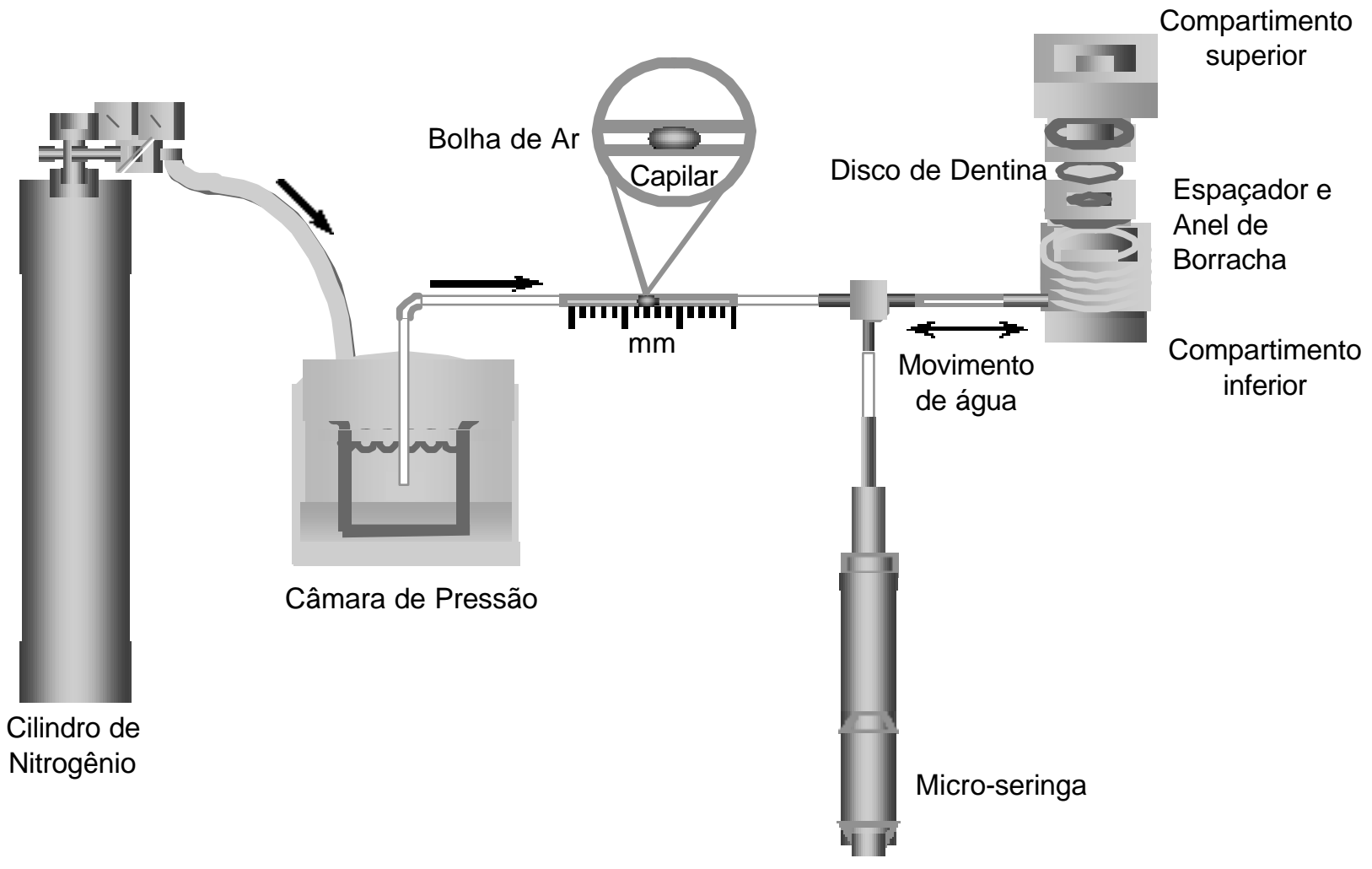

Figura 21 - Desenho esquemático do sistema para medição da permeabilidade dentinária como condutividade hidráulica (Lp), adaptado de Pashley e Galloway, em 1985, com seus componentes: cilindro de nitrogênio, câmara de pressão, micro-seringa e capilar de vidro com a bolha de ar, câmara de filtração com o disco de dentina.

\subsubsection{Câmara de Filtração}

A câmara de filtração ${ }^{9}$, representada na Figura 22A, é a porção final do sistema de medição que abriga os espécimes de dentina e fica conectada à câmara de pressão por meio dos capilares de polietileno. É formada por dois compartimentos de plexiglass que se encaixam por rosqueamento, um superior e outro inferior. O compartimento inferior da câmara desmontável possui dois orifícios, conectados por tubos metálicos a capilares de polietileไno, para a circulação do líquido pressurizado. Um dos tubos metálicos funciona como entrada do líquido sob pressão no segmento inferior da câmara. Outro é mantido vedado e destina-se à drenagem do líquido para remoção de eventuais bolhas de ar. $\mathrm{O}$

\footnotetext{
${ }^{9}$ Norway Tool and Engineering Co., Los Angeles, USA.
} 
compartimento superior encaixa-se por rosqueamento no compartimento inferior e apresenta uma abertura central através da qual se tem acesso à superfície oclusal dos discos de dentina, onde se aplicam os materiais experimentais.

Os compartimentos da câmara são interligados por dois espaçadores, também de plexiglass, com abertura central de diâmetro padronizado, determinando áreas opcionais de superfície dentinária de 0,178 ou $0,282 \mathrm{~cm}^{2}$, conforme as dimensões dos discos de dentina disponíveis (Figuras 22B e 22C). Os discos de dentina, através dos quais se filtrava o líquido, eram adaptados entre os espaçadores, justapostos por anéis de borracha para vedação, dividindo a câmara de filtração em dois ambientes: um interno, interligado ao sistema de circulação de líquido, e outro externo, voltado para a superfície onde foram realizados os ensaios. Os discos eram posicionados para permitir que a filtração do líquido fosse padronizada, da superfície pulpar para a oclusal dos espécimes.

\subsubsection{Câmara de Pressão}

A câmara de pressão é uma panela de pressão ${ }^{10}$ modificada para receber o condutor de pressão, que é um tubo de polietileno, proveniente de um cilindro de nitrogênio. Dentro dela, um reservatório com capacidade para armazenar $600 \mathrm{ml}$ de água deionizada, recebe um capilar de polietileno que, por meio de um dispositivo de acoplagem, localizado na tampa da câmara de pressão, comunica-se com o sistema capilar externo, destinado a conduzir a água deionizada sob a pressão do nitrogênio. O volume de água deionizada era reposto periodicamente durante o procedimento de filtração. Ainda na tampa da câmara de pressão está adaptada uma válvula de segurança que permite a descompressão quando necessária. Sendo hermeticamente fechada, a câmara de pressão possibilitava a indução de uma pressão constante de $703,1 \mathrm{~cm} \mathrm{H} \mathrm{H}_{2} \mathrm{O}$ através de todo o sistema capilar abastecido com água deionizada. 
I
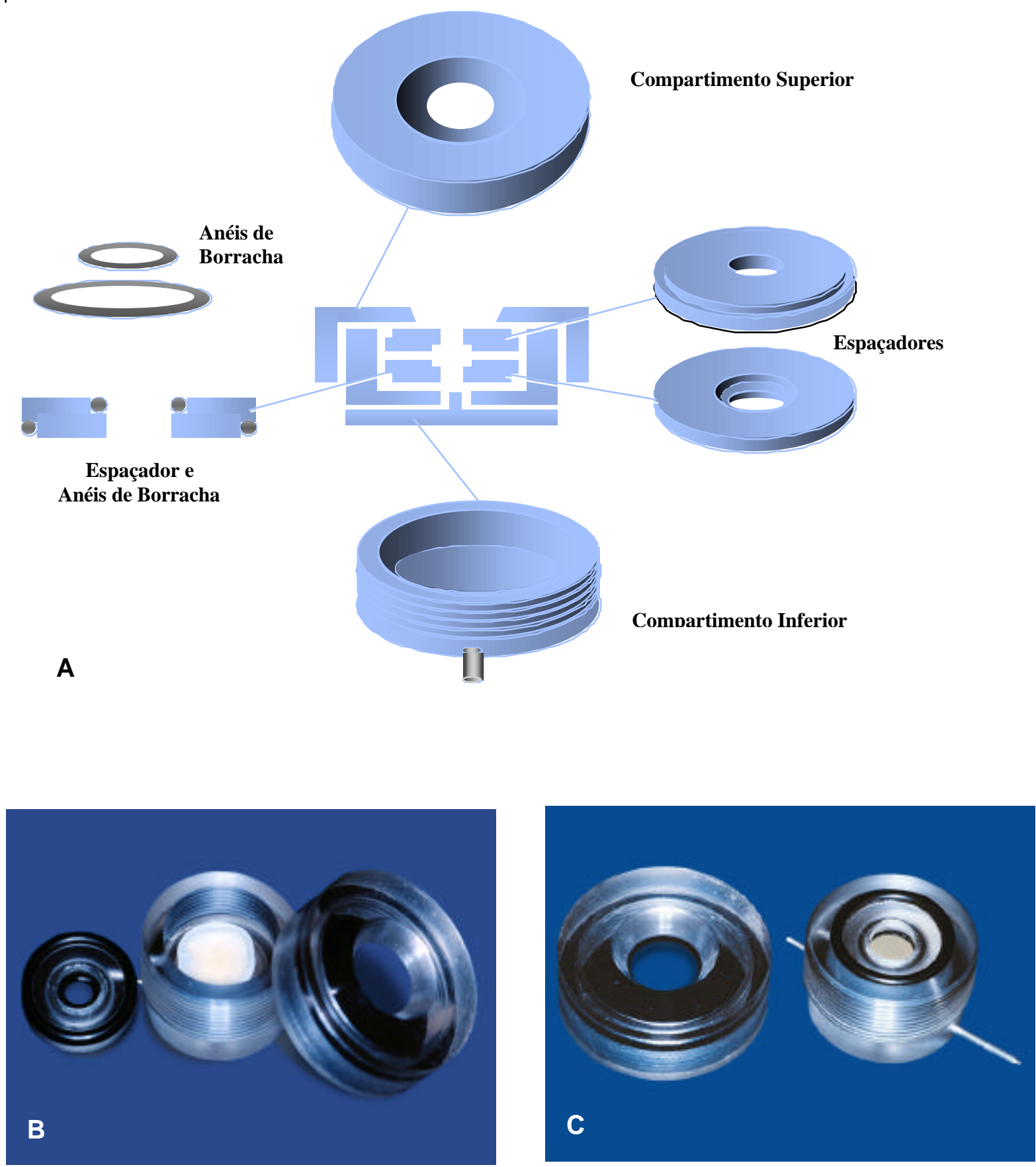

Figura 22 - A - Desenho esquemático dos componentes da câmara de filtração: compartimentos superior e inferior, espaçadores e anéis de borracha; B - Disco de dentina posicionado sobre o espaçador no compartimento inferior da câmara de filtração; C - Espaçador do

\footnotetext{
${ }^{10}$ Alcan Alumínio, 5,7 litros, Brasil.
} 
compartimento superior adaptado sobre o disco de dentina, mostrando a área da superfície dentinária onde foram realizados os testes.

\subsubsection{Cilindro de Nitrogênio}

O nitrogênio utilizado para pressurização do sistema é acondicionado num cilindro de metal $^{11}$, que possui uma válvula para liberação do nitrogênio e dois manômetros ${ }^{11}$ : um para monitorar a pressão interna do cilindro e outro para determinar a pressão de trabalho, utilizada para forçar o líquido através de todo o circuito.

O sistema começa a funcionar quando a válvula é aberta e libera o nitrogênio do cilindro. A partir daí, o manômetro é regulado para determinar a pressão de trabalho em $703,1 \mathrm{~cm} \mathrm{H} \mathrm{H}_{2} \mathrm{O}$ ou $10 \mathrm{psi}$, ou ainda, $1,05 \mathrm{~kg} / \mathrm{cm}^{2}$. Essa pressão se manteve constante durante todo o experimento.

\subsubsection{Sistema Capilar de Polietileno e Componentes para Leitura}

O sistema de capilares ${ }^{12}$ funciona como elo entre a câmara de pressão e a câmara de filtração, sendo que neste percurso, encontram-se os componentes responsáveis pela leitura da filtração da água deionizada através da dentina: o capilar de vidro ${ }^{13}$ e a microseringa ${ }^{14}$. O capilar de vidro, que possui $65 \mathrm{~mm}$ de comprimento e capacidade de $25 \mu \mathrm{l}$, está justaposto a uma escala de medição em milímetros, a qual serve para medir o deslocamento do líquido numa fração de tempo, conforme a velocidade de filtração nos discos de dentina.

O movimento da água deionizada era monitorado pelo deslocamento de uma bolha de ar, produzida pela micro-seringa, sobre uma régua milimetrada (Figura 23). A microseringa, acoplada a uma extensão capilar de polietileno situado entre o capilar de vidro e a

\footnotetext{
${ }^{11}$ White Martins, São Paulo, Brasil.

${ }^{12}$ CPL Medical's Produtos Médicos Ltda., São Paulo, Brasil.

${ }^{13}$ Fisher Scientific Company, Pittsburgh, USA.

${ }^{14}$ Gilmont Instruments Inc, Great Neck, New York, USA.
} 
câmara de filtração, é composta por um reservatório com água deionizada e um cursor. Tem as funções de formar a bolha de ar e de posicioná-la adequadamente no capilar, ajustando-a na escala milimetrada, injetando ou retirando a quantidade apropriada de água. $\mathrm{O}$ deslocamento linear da bolha de ar representava o deslocamento volumétrico de líquido por minuto ( $\mu \mathrm{l} / \mathrm{min})$, através do disco de dentina.

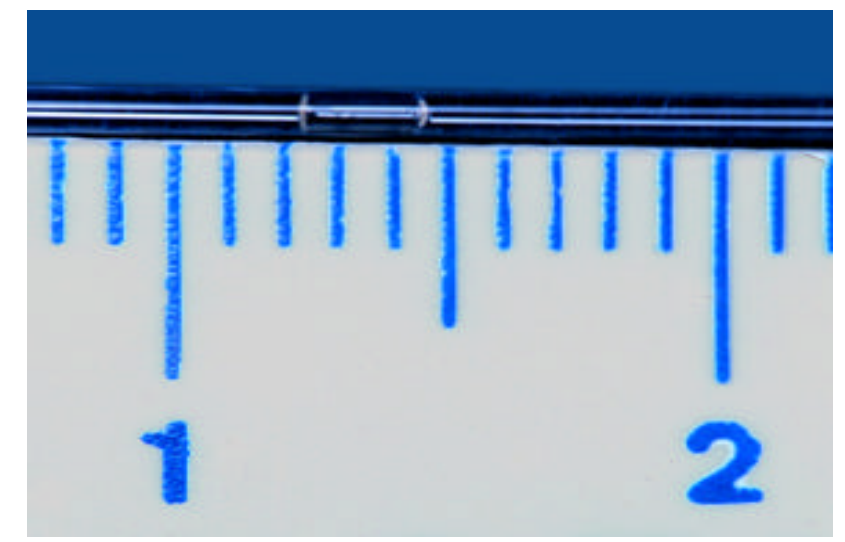

Figura 23 - Bolha de ar no interior do capilar de vidro, sobre a régua milimetrada, acompanhando o deslocamento do líquido através do disco de dentina.

\subsubsection{Materiais e Condições Experimentais}

Para os ensaios quantitativos da permeabilidade dentinária, os 200 discos de dentina preparados da maneira já descrita foram divididos em 20 grupos de dez dentes, correspondentes a quatro materiais experimentais sob cinco condições de pré-tratamento da superfície dentinária. Foram experimentados quatro materiais empregados clinicamente para o tratamento da hiperestesia dentinária, sendo três géis à base de oxalato de potássio monohidratado e um gel de fluorfosfato de sódio acidulado, conforme Tabela 1. Os agentes antihiperestésicos foram aplicados sobre as superfícies oclusais dos discos de dentina, submetidos a diferentes pré-tratamentos, também dispostos na Tabela 1. 
Tabela 1 - Distribuição da amostragem conforme os materiais anti-hiperestésicos e as diferentes formas de pré-tratamento da dentina estudados nos ensaios de condutividade hidráulica.

\begin{tabular}{|c|c|c|c|}
\hline Material & \multirow{2}{*}{ 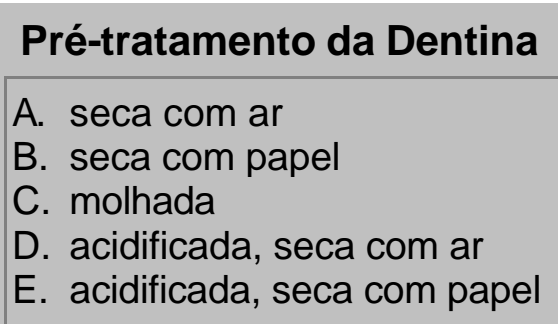 } & \multicolumn{2}{|c|}{ № de Espécimes } \\
\hline $\begin{array}{l}\text { 1. Oxa-Gel }{ }^{15} \text { Art-Dent - Brasil } \\
\text { Solução de oxalato de potássio } \\
\text { mono-hidratado }{ }^{16} \text { a } 3 \%+ \\
\text { carboximetilcelulose }{ }^{17} \\
\text { gel - pH } 4,10\end{array}$ & & $\begin{array}{l}10 \\
10 \\
10 \\
10 \\
10\end{array}$ & 50 \\
\hline $\begin{array}{l}\text { 2. Experimental } 1 \\
\text { solução de oxalato de potássio } \\
\text { mono-hidratado a } 6 \%+ \\
\text { carboximetilcelulose } \\
\text { gel - pH } 4,03\end{array}$ & $\begin{array}{l}\text { A. seca com ar } \\
\text { B. seca com papel } \\
\text { C. molhada } \\
\text { D. acidificada, seca com ar } \\
\text { E. acidificada, seca com papel }\end{array}$ & $\begin{array}{l}10 \\
10 \\
10 \\
10 \\
10\end{array}$ & 50 \\
\hline $\begin{array}{l}\text { 3. Experimental } 2 \\
\text { solução de oxalato de potássio } \\
\text { mono-hidratado a } 3 \%+ \\
\text { carbopol }{ }^{17} \\
\text { gel - pH } 2,52\end{array}$ & $\begin{array}{l}\text { A. seca com ar } \\
\text { B. seca com papel } \\
\text { C. molhada } \\
\text { D. acidificada, seca com ar } \\
\text { E. acidificada, seca com papel }\end{array}$ & $\begin{array}{l}10 \\
10 \\
10 \\
10 \\
10\end{array}$ & 50 \\
\hline $\begin{array}{l}\text { 4. Nupro Acidulated Gel }{ }^{18} \\
\text { Dentsply - Brasil } \\
\text { solução de fluorfosfato de sódio } \\
\text { acidulado a } 1,23 \% \\
\text { pH } 3,6 \text { a } 3,9\end{array}$ & $\begin{array}{l}\text { A. seca com ar } \\
\text { B. seca com papel } \\
\text { C. molhada } \\
\text { D. acidificada, seca com ar } \\
\text { E. acidificada, seca com papel }\end{array}$ & $\begin{array}{l}10 \\
10 \\
10 \\
10 \\
10\end{array}$ & 50 \\
\hline
\end{tabular}

\subsubsection{Execução dos Testes}

O índice de filtração da água deionizada através da dentina foi medido, para cada um dos quatro materiais sob os cinco pré-tratamentos superficiais, na seguinte seqüência experimental:

\footnotetext{
${ }^{15}$ Art Dent Indústria \& Comércio Ltda., Araraquara, Brasil.

${ }^{16}$ Merck, Darmstadt, Germany.

${ }^{17}$ Henrifarma Produtos Químicos e Farmacêuticos Ltda., São Paulo, Brasil.
} 
a. na presença de smear layer, obtendo-se a permeabilidade mínima;

b. após a remoção da smear layer com $\operatorname{EDTA}^{19}$ a 0,5 M, por um minuto, para se obter a permeabilidade máxima da dentina;

c. após a aplicação passiva dos agentes anti-hiperestésicos em teste, diante de cada um dos cinco pré-tratamentos da superfície dentinária;

d. após desafio com ácido cítrico ${ }^{19}$ a $6 \%$, por um minuto.

Assim, duas situações básicas foram adotadas para a determinação do efeito dos materiais e pré-tratamentos superficiais sobre a condutividade hidráulica da dentina. A primeira considera a presença da smear layer como a condição mais efetiva para obstruir os túbulos dentinários e reduzir o fluxo de líquido através da dentina. A segunda pressupõe que a remoção da smear layer é a condição que permite a maior permeabilidade da dentina. Dessa forma, a condutividade hidráulica dos espécimes foi medida, inicialmente, na presença da smear layer e, em seguida, após sua remoção através do condicionamento ácido, estabelecendo-se, desta maneira, os valores de permeabilidade mínima e máxima de cada espécime, individualmente.

\subsubsection{Determinação da Permeabilidade Mínima (smear layer)}

Os discos de dentina eram imersos em EDTA 0,5 M com pH 7,4, durante um minuto, e lavados abundantemente com água deionizada. Obtinham-se, assim, espécimes com ambas as superfícies livres de resíduos resultantes da preparação dos discos. Em seguida, produzia-se uma smear layer padronizada na superfície oclusal dos espécimes, utilizando uma lixa de carbeto de silício de granulação 320 adaptada à plataforma circular da politriz, sob pressão digital e sob água corrente. Os espécimes de dentina eram posicionados na periferia do disco de lixa, que girava a 125 rotações por minuto. Elegeu-se um tempo de

\footnotetext{
${ }^{18}$ Dentsply Indústria \& Comércio Ltda., Brasil.

${ }^{19}$ Merck, Darmstadt, Germany.
} 
lixamento de cinco segundos, controlado com cronômetro digital ${ }^{20}$, substituindo-se as folhas de lixa a cada três espécimes.

Em seguida, a superfície pulpar dos discos de dentina era submetida a novo condicionamento com EDTA a $0,5 \mathrm{M}$, durante um minuto, para garantir a remoção de resíduos que pudessem obstruir as extremidades pulpares dos túbulos dentinários. Portanto, apenas a smear layer do lado oclusal dos discos de dentina era mantida.

Os espécimes eram, então, adaptados na câmara de filtração para a medição da permeabilidade dentinária, com o lado pulpar voltado para o interior da câmara e o lado oclusal voltado para o meio externo, estando o circuito de líquido obstruído sob pressão de uma pinça hemostática no capilar de polietileno. Após esse procedimento, com o circuito de líquido agora desobstruído, media-se a filtração obtendo-se a permeabilidade mínima da dentina. Foram realizadas quatro medidas consecutivas do movimento da bolha através do capilar sobre a escala milimetrada a fim de computar os valores médios para cada disco de dentina antes e depois de cada situação. Essas medidas eram representadas pela distância percorrida pela bolha, em milímetros, num determinado tempo em minutos, determinados para cada espécime, conforme a velocidade de deslocamento da bolha.

Os espécimes com filtrações mais discrepantes eram descartados com a intenção de aproveitar aqueles com uma variação de filtração entre 10 e $30 \mu \mathrm{l} / \mathrm{min}$, tornando a amostra a mais homogênea possível.

\subsubsection{Determinação da Permeabilidade Máxima (EDTA a 0,5 M)}

Com os discos ainda acoplados na câmara de filtração obtinha-se a permeabilidade máxima submetendo a porção oclusal dos mesmos ao condicionamento com EDTA a 0,5 M, $\mathrm{pH} 7,4$, durante um minuto, para a remoção da smear layer, lavando-se ou não a área

\footnotetext{
${ }^{20}$ Hanhart GmbH \& Co KG, Germany.
} 
condicionada por dez segundos com água deionizada, conforme a condição de prétratamento da dentina a ser experimentada. O tratamento com EDTA permitia a maximização da permeabilidade dentinária e a simulação laboratorial mais próxima à condição clínica da hiperestesia dentinária. Os índices assim obtidos foram considerados como sendo $100 \%$ da filtração de cada espécime. Os demais índices percentuais, incluindo os efeitos dos materiais experimentais, da smear layer e do condicionamento com ácido cítrico, foram calculados como uma proporção dessa permeabilidade máxima de $100 \%$.

\subsubsection{Pré-tratamentos da Dentina e Aplicação dos Agentes Anti-hiperestésicos}

Previamente à aplicação dos materiais em experimentação e após o condicionamento com EDTA, a superfície dentinária era submetida a um dos cinco prétratamentos:

a. lavada com jatos de água deionizada durante dez segundos e seca com cinco jatos de $\operatorname{ar}^{21}$;

b. lavada e seca com papel absorvente ${ }^{22}$;

c. lavada e mantida úmida;

d. não lavada e seca com ar;

e. não lavada e seca com papel absorvente.

Em seguida ao pré-tratamento de superfície, os agentes anti-hiperestésicos eram depositados passivamente com pincel $^{23}$ sobre a superfície dentinária exposta, acessível através do orifício do compartimento superior da câmara de filtração. Os géis derivados de oxalato de potássio e o gel de flúor eram aplicados por três e quatro minutos, respectivamente, conforme recomendações dos respectivos fabricantes. Esses materiais

\footnotetext{
${ }^{21}$ Dust-Off, Falcon Safety Products, Branchburg, USA.

${ }^{22}$ Grand Hotel, Klabin, São Paulo, Brasil.

${ }^{23}$ Microbrush, K G Sorensen Indústria e Comércio, São Paulo, Brasil.
} 
foram removidos com jatos de água deionizada, direcionados indiretamente por dez segundos, para que imediatamente a filtração fosse medida.

\subsubsection{Desafio com Ácido Cítrico a $6 \%$}

A superfície tratada dos discos era, em seguida, exposta à última situação experimental, que se refere ao condicionamento com ácido cítrico a $6 \%, \mathrm{pH} 2,1$, por um minuto. Esse tratamento teve a finalidade de avaliar a resistência dos eventuais efeitos oclusivos dos materiais estudados a um meio ácido recorre

nte e é aqui referido como desafio ácido.

Essa seqüência de procedimentos era realizada sem que o disco de dentina fosse removido da câmara de filtração e repetia-se para todos os grupos experimentais. Os resultados das medições eram organizados em uma ficha que continha, para todas as condições, a distância percorrida pela bolha e o tempo necessário para percorrê-la. $\mathrm{Na}$ mesma ficha, anotavam-se os valores da condutividade hidráulica, a média aritmética das condutividades hidráulicas e seus valores relativos em percentagem, como mostra a Tabela 2.

\subsubsection{Análise dos Resultados de Condutividade Hidráulica}

Tendo em mãos os valores de deslocamento da bolha e o tempo, procedeu-se ao cálculo da permeabilidade dentinária, expressa em termos de condutividade hidráulica da dentina (Lp). Para tanto, aplicou-se uma equação em que a velocidade e o tempo de deslocamento da bolha são as variáveis, e o calibre e o volume do capilar, a pressão hidrostática e a área de superfície são as constantes. 
Tabela 2 - Ficha para o registro dos dados obtidos nos ensaios de condutividade hidráulica e respectivos cálculos de Lp e percentagem.

\section{Condutividade Hidráulica - ficha para registro de dados}

\begin{tabular}{|l} 
Projeto: $\begin{array}{l}\text { Avaliação da permeabilidade dentinária após tratamento de superfície com } \\
\text { diferentes agentes anti-hiperestésicos. Estudo in vitro. }\end{array}$ \\
\hline
\end{tabular}

Data - Analisada por - Angela Disco - $\quad$ Espessura - $\quad \mathrm{mm}$
Capilar - $25 \mu \mathrm{l} 65 \mathrm{~mm}$
Área de superfície -
$\mathrm{cm}^{2} \quad$ Pressão $-703,1 \mathrm{~cm} \mathrm{H} \mathrm{O}$

Experimento -

Condição - Smear-layer
\begin{tabular}{|clc|}
\hline $\mathrm{mm}$ & $\min$ \\
\hline $\mathrm{mm}$ & $\min$ \\
\hline $\mathrm{mm}$ & $\min$ \\
\hline $\mathrm{mm}$ & $\min$ \\
\hline & & $\mathrm{x}-$ \\
& & \\
\hline & & \\
\hline
\end{tabular}

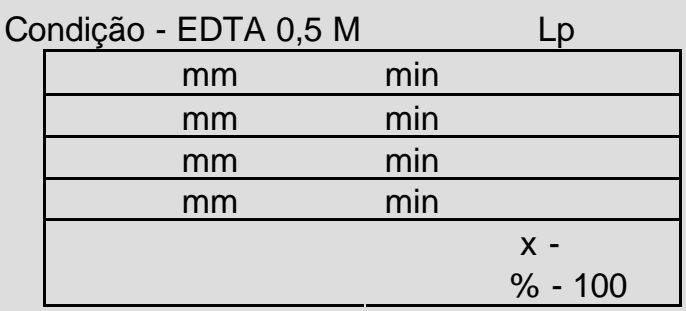

Condição - Material

Lp

\begin{tabular}{|c|c|}
\hline $\mathrm{mm}$ & $\min$ \\
\hline $\mathrm{mm}$ & $\min$ \\
\hline $\mathrm{mm}$ & $\min$ \\
\hline $\mathrm{mm}$ & $\min$ \\
\hline & $\begin{array}{l}x- \\
\%-\end{array}$ \\
\hline
\end{tabular}

\begin{tabular}{|c|c|c|}
\hline Condição - Ácido & a $6 \%$ & Lp \\
\hline $\begin{array}{r}\mathrm{mm} \\
\end{array}$ & $\min$ & \\
\hline $\mathrm{mm}$ & $\min$ & \\
\hline $\mathrm{mm}$ & $\min$ & \\
\hline $\mathrm{mm}$ & $\min$ & \\
\hline & & $\begin{array}{l}x- \\
\%-\end{array}$ \\
\hline
\end{tabular}

Os valores de Lp obtidos após a aplicação do EDTA representavam a filtração máxima (100\%), sendo os valores de Lp das demais condições experimentais calculados como uma proporção da permeabilidade máxima. Dessa forma, cada disco serviu como seu próprio controle, onde os valores de filtração na presença da smear layer, após o tratamento com os géis experimentais e após o desafio ácido, variavam percentualmente em relação ao valor obtido após o condicionamento com EDTA.

A condutividade hidráulica (Lp), expressa em $\mu \mathrm{cm}^{-2} \mathrm{~min}^{-1} \mathrm{~cm} \mathrm{H}_{2} 0$, é o resultado do quociente entre a filtração dentinária $(\mathrm{Q})$ e a pressão hidrostática $(P)$ multiplicada pela área de superfície dentinária exposta (SA). Essas medições podem ser expressas pela seguinte equação: 


$$
L p=\frac{Q}{P(S A)}
$$

onde,

$\mathrm{Lp}=$ condutividade hidráulica da dentina em $\mu \mathrm{cm}^{-2} \mathrm{~min}^{-1} \mathrm{~cm} \mathrm{H}_{2} \mathrm{O}$

$\mathrm{Q}=$ índice de filtração em $\mu \mathrm{l} \mathrm{min}^{-1}$

$\mathrm{SA}=$ área da superfície dentinária em $\mathrm{cm}^{2}$

$P=$ diferença da pressão hidrostática através da dentina em $\mathrm{cm} \mathrm{H}_{2} \mathrm{O}$

Como o capilar utilizado para medir o índice de filtração $(Q)$ tem diâmetro constante, dividindo o volume do capilar $(25 \mu \mathrm{l})$ pelo seu comprimento $(65 \mathrm{~mm})$, obtém-se uma proporcionalidade constante, que relacionada com a distância percorrida pela bolha $(x \mathrm{~mm})$ e o tempo gasto para tal (y minutos), converte o deslocamento linear em volume deslocado. Isto é,

$$
\mathrm{Q}=\frac{25 \mu \mathrm{l} .(\mathrm{x}) \mathrm{mm}}{65 \mathrm{~mm} \cdot(\mathrm{y}) \min }
$$

A pressão hidrostática $(\mathrm{P})$ foi convertida $\mathrm{em} \mathrm{cm} \mathrm{H}_{\mathrm{Q}} \mathrm{O}$ antes de se calcularem os valores de condutividade hidráulica, e mantida constante em $703,1 \mathrm{~cm} \mathrm{H} \mathrm{H}_{2} \mathrm{O}$ durante todo o experimento. A área de superfície (SA), determinada pelo diâmetro dos espaçadores da câmara de filtração e selecionada dependentemente das dimensões dos discos de dentina disponíveis, era padronizada em 0,178 ou $0,282 \mathrm{~cm}^{2}$.

Com o intuito de simplificar os cálculos de condutividade hidráulica e percebendo que parâmetros como a pressão, o calibre e o volume do capilar mantiveram-se constantes durante toda a experimentação, os cálculos preliminares incluindo esses valores foram pré- 
definidos em duas equações específicas para cada área de superfície utilizada. Assim, quando a área de superfície dentinária exposta pelo espaçador era de $0,282 \mathrm{~cm}^{2}$, a equação utilizada foi a A e, para o espaçador menor, de $0,178 \mathrm{~cm}^{2}$, a equação foi B. Esses cálculos de Lp foram realizados com o auxílio do programa Microsoft Excel $97^{24}$.

$$
L p=\frac{0,0019398155 .(x) \mathrm{mm}}{(y) \min }
$$

(y) $\min$
A

$$
L p=\frac{0,0030731909 \cdot(x) \mathrm{mm}}{(y) \min }
$$

(y) $\min$

\subsubsection{Planejamento Estatístico}

Devido à variabilidade biológica da dentina, da profundidade do esmalte e da altura dos cornos pulpares, cada disco é diferente de todos os outros discos. Isso introduz aos dados uma variabilidade biológica inerente quando analisados como um grupo. Para diminuir essa variabilidade, os dados foram calculados como a mudança percentual da condutividade hidráulica após cada etapa da seqüência experimental, em relação ao valor máximo de $100 \%$ obtido pelo EDTA, utilizando cada disco como seu próprio controle.

As médias e o desvio padrão das mudanças percentuais na $L p$ foram calculadas. As diferenças intergrupos foram identificadas através da análise de variância a dois critérios. As diferenças estatisticamente significantes entre os grupos foram rastreadas utilizando teste Múltiplo de Duncan. O mesmo teste foi utilizado para calcular as diferenças intragrupos. Para todos os testes convencionou-se o nível de significância de $5 \%(p<0,05)$, empregando-se o programa Statistica $5.1^{25}$.

\footnotetext{
${ }^{24}$ Microsoft Corporation, Redmond, USA.

${ }^{25}$ Statsoft, Tulsa, Oklahoma, USA.
} 


\subsection{Ensaios em Microscopia Eletrônica de Varredura}

\subsubsection{Seleção dos Dentes e Obtenção dos Espécimes}

As imagens da dentina analisada em microscopia eletrônica de varredura foram obtidas a fim de permitir a correlação entre os dados de filtração e os obtidos a partir da aparência das superfícies dentinárias.

Para o estudo microscópico, outros 20 dentes terceiros molares humanos hígidos foram selecionados, extraídos, armazenados e preparados como discos de dentina, secionando-os com disco de diamante e lixando-os na politriz, exatamente como foi descrito para os experimentos de condutividade hidráulica.

\subsubsection{Materiais e Seqüência Experimental}

A escolha do pré-tratamento superficial da dentina, previamente à aplicação do agente anti-hiperestésico, baseou-se na análise dos resultados alcançados pelos vários prétratamentos experimentados no teste de condutividade hidráulica. Assim, considerou-se que a dentina lavada e seca com ar após ter sido condicionada com EDTA a 0,5 M, obteve o melhor desempenho por proporcionar um percentual de filtração, após a aplicação dos agentes anti-hiperestésicos, o mais próximo ao obtido na presença da smear layer, independente do material utilizado.

Para os ensaios em microscopia eletrônica de varredura, 20 discos de dentina preparados da maneira já descrita foram divididos em quatro grupos de cinco espécimes, correspondentes a quatro materiais experimentais sob a condição de pré-tratamento superficial selecionada. Portanto, os agentes anti-hiperestésicos, Oxa-Gel, Experimental 1, Experimental 2 e Gel Fluoretado, foram aplicados sobre as superfícies oclusais dos discos de dentina, condicionadas, lavadas e secas com ar. 
A amostragem foi, então, distribuída entre os 20 discos de dentina, cada disco contendo as quatro etapas do experimento realizadas seqüencialmente, conforme a Tabela 3.

Tabela 3 - Distribuição dos materiais e seqüência experimental utilizados nos ensaios de microscopia eletrônica de varredura.

\section{Materiais}

1. Oxa-Gel

solução de oxalato de potássio mono-hidratado a $3 \%+$ carboximetilcelulose

Gel - pH 4,10

\section{Experimental 1}

solução de oxalato de potássio mono-hidratado a $6 \%+$ carboximetilcelulose

Gel - pH 4,03

\section{Experimental 2}

solução de oxalato de potássio mono-hidratado a $3 \%+$ carbopol

Gel - pH 2,52

\section{Nupro Acidulated Gel} solução de fluorfosfato de sódio acidulado a $1,23 \%$

$\mathrm{pH} \mathrm{3,6} \mathrm{a} \mathrm{3,9}$

\section{Seqüência Experimental}

№ de Espécimes
A. smear layer
B. condicionada com EDTA, lavada e seca com ar
5 discos
C. tratada com Oxa-Gel
D. desafio ácido
A. smear layer
B. condicionada com EDTA, lavada e seca com ar
5 discos
C. tratada com Experimental 1
D. desafio ácido
A. smear layer
B. condicionada com EDTA, lavada e seca com ar
5 discos
C. tratada com Experimental 2
D. desafio ácido
A. smear layer
B. condicionada com EDTA, lavada e seca com ar
C. tratada com Nupro Gel
D. desafio ácido

\subsubsection{Confecção das Canaletas de Fratura}

Imediatamente antes da realização dos ensaios foi realizada a limpeza de ambos os lados dos discos com EDTA 0,5 M durante um minuto, seguido do lixamento da superfície oclusal dos discos, com lixa 320 durante cinco segundos, a uma velocidade de 125 rpm, para a padronização da smear layer. As superfícies oclusais dos discos foram atentamente observadas sob magnificação de dez vezes, a fim de se delimitarem as regiões sob as quais estavam os cornos pulpares, discernidas por apresentarem-se mais escurecidas. 
Duas canaletas, paralelas entre si, interligando as regiões correspondentes aos cornos pulpares mesiais e distais, respectivamente, foram realizadas a fim de orientar a direção de fratura dos espécimes e expor longitudinalmente os canalículos dentinários nas áreas submetidas aos experimentos. Essas canaletas na superfície pulpar, realizadas com ponta diamantada esférica $\mathrm{n}^{\circ} 1014^{26}$ sob refrigeração, delimitaram os discos de dentina em três segmentos, como mostra a Figura 24, permitindo, ao mesmo tempo, a análise da superfície tratada e a espessura do disco fraturado.

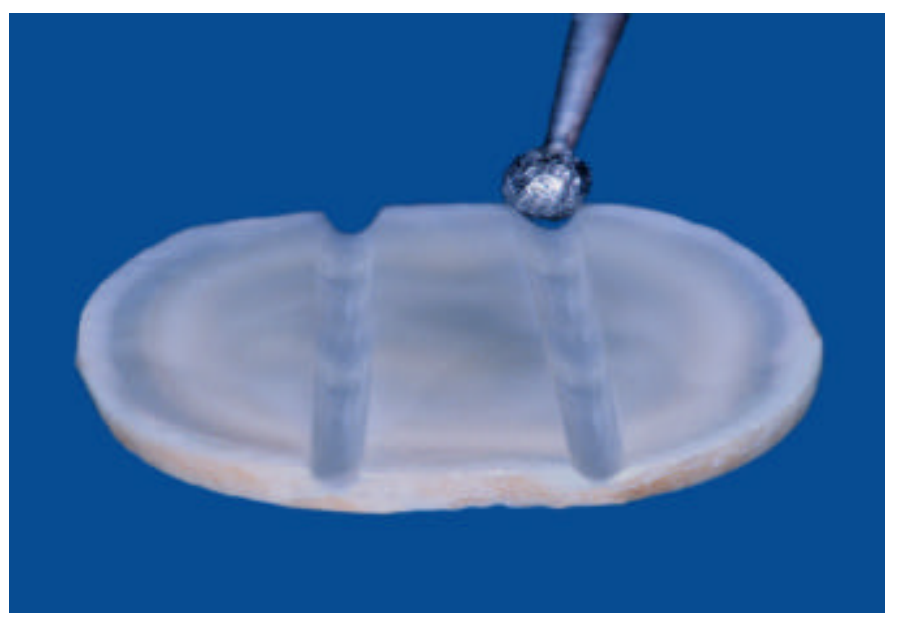

Figura 24 - Confecção de canaletas na superfície pulpar, com ponta diamantada esférica, direcionando a fratura para permitir a análise da espessura do disco

\subsubsection{Execução dos Testes}

O experimento foi realizado na superfície oclusal, na mesma seqüência de situações realizadas para os ensaios de condutividade:

a. na presença de smear layer;

b. após o condicionamento da smear layer com EDTA a 0,5 M, por um minuto;

c. após a aplicação passiva dos agentes anti-hiperestésicos em teste, diante da condição de pré-tratamento superficial escolhido;

d. após desafio com ácido cítrico a $6 \%$, por um minuto.

\footnotetext{
${ }^{26}$ K G Sorensen Indústria e Comércio, São Paulo, Brasil.
} 
Para acomodar essas situações na mesma amostra de dentina, o discos foram agora delimitados imaginariamente pelo lado oclusal em quatro partes, cada uma correspondendo a um dos cornos pulpares (Figura 25).

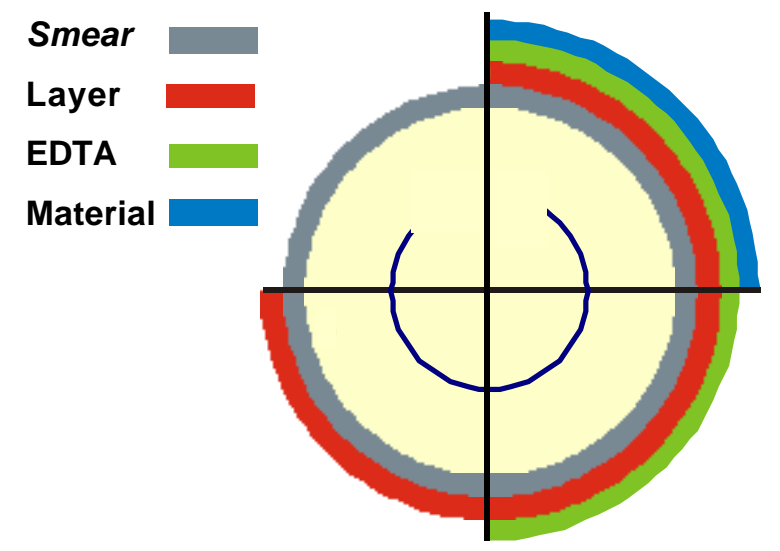

Figura 25 - Desenho esquemático do disco de dentina delimitado conforme a seqüência experimental executada.

Em seguida, 2/3 da superfície oclusal dos discos foram submetidos ao condicionamento com EDTA a $0,5 \mathrm{M}$, durante um minuto, deixando a quarta parte livre do condicionamento, reservada para a observação microscópica da smear layer. A fim de se preservar intacta a smear layer, os discos eram mantidos inclinados durante o condicionamento ácido e a lavagem para impedir que o ácido ou mesmo a água subseqüente à lavagem pudesse contaminar aquela superfície. Após o condicionamento, as superfícies eram lavadas com água deionizada, por dez segundos, e secas com cinco jatos de ar a uma distância aproximada de $10 \mathrm{~cm}$.

Dos $3 / 4$ do disco condicionados com EDTA, 2/4 foram submetidos à ação dos materiais anti-hiperestésicos. Os quatro materiais foram aplicados conforme as especificações do fabricante, da mesma maneira como foram aplicados para o experimento de condutividade hidráulica, mas mantendo o disco inclinado durante a lavagem a fim de se 
evitar que o escoamento do material interferisse nas superfícies ensaiadas do lado oposto: smear layer e EDTA.

$\mathrm{Na}$ quarta parte superior direita dos discos, após a aplicação do agente antihiperestésico, a superfície foi submetida ao desafio com ácido cítrico a $6 \%$ por um minuto, lavada e seca com ar. O desafio ácido, nessa etapa do experimento, teve a finalidade de verificar a resistência à dissolução dos precipitados decorrentes da reação dos agentes experimentais com a dentina. As superfícies assim tratadas eram codificadas para posterior identificação no momento da fratura.

\subsubsection{Preparo dos Espécimes e Análise em M.E.V.}

Uma vez terminados os ensaios, os discos foram acondicionados em recipientes individuais, contendo sílica gel ${ }^{27}$ envolta por papel filtro, e mantidos em uma câmara dessecadora ${ }^{28}$ a $37^{\circ} \mathrm{C}$, durante aproximadamente uma semana.

Depois de desidratados, os discos foram fraturados seguindo a orientação das canaletas pré-realizadas no lado pulpar, com o auxílio de um cinzel ${ }^{29}$, obtendo-se três fragmentos de cada disco. A Figura 26 ilustra um disco fraturado, expondo sua espessura transversalmente às áreas experimentadas.

Para viabilizar a captação das imagens pelo microscópio eletrônico de varredura ${ }^{30}$, os dois fragmentos mais externos de cada disco fraturado foram montados em portaamostras de alumínio com o auxílio de fitas adesivas de carbono ${ }^{31}$. Os fragmentos centrais foram reservados para eventual utilização, se necessário. Os espécimes receberam uma

\footnotetext{
${ }^{27}$ Henrifarma Produtos Químicos e Farmacêuticos Ltda., São Paulo, Brasil.

${ }^{28}$ Fanem Ltda., São Paulo, Brasil.

${ }^{29}$ SS White Artigos Dentários Ltda., Juiz de Fora, Brasil.

${ }^{30}$ LEO Stereoscan 440, LEO Electron Microscopy Ltda., England.

${ }^{31} 3 \mathrm{M}$, Minnesota, USA.
} 
cobertura de $20 \mathrm{~nm}$ de ouro-paládio ${ }^{32}$, utilizando-se uma corrente de $50 \mathrm{~mA}$, num tempo aproximado de 150 segundos de evaporação ${ }^{33}$ (Figura 27).
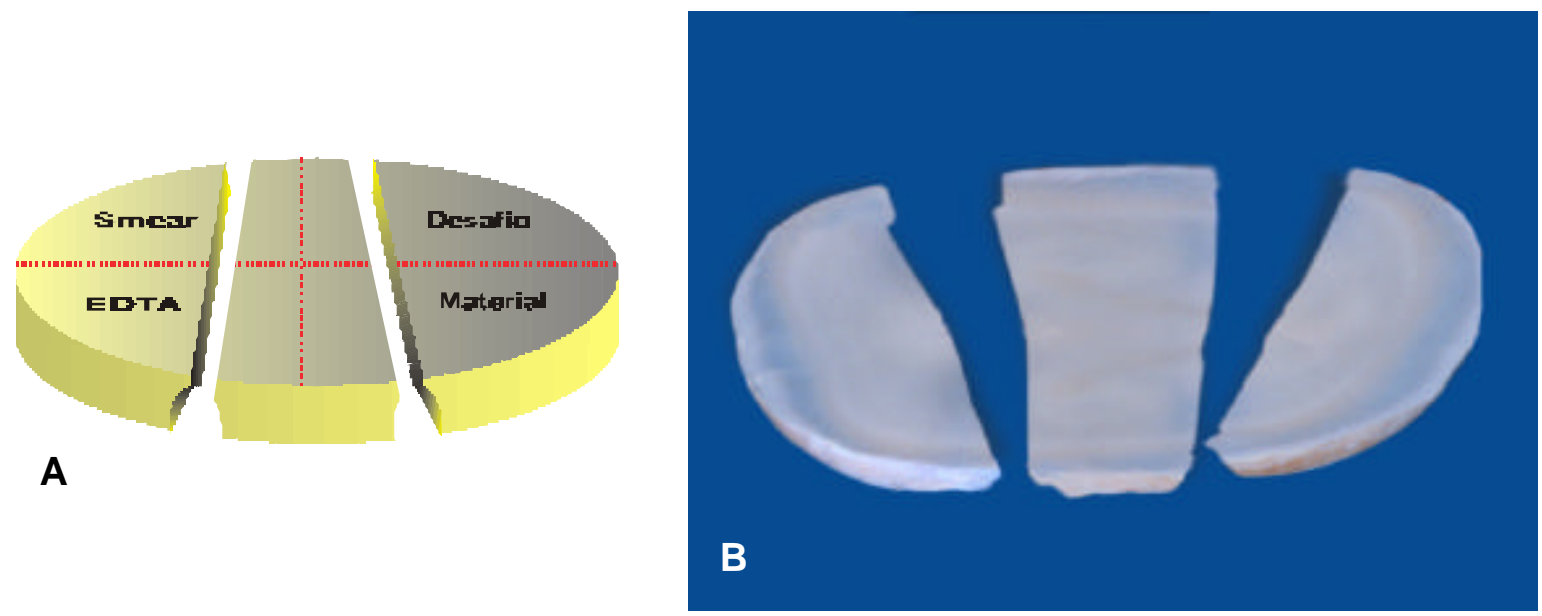

Figura 26 - A - Desenho esquemático do disco de dentina fraturado de acordo com a orientação das canaletas, mostrando as áreas da superfície e da espessura da fratura de cada etapa da seqüência experimental; B - Fragmentos do disco de dentina após ter sido desidratado e fraturado.

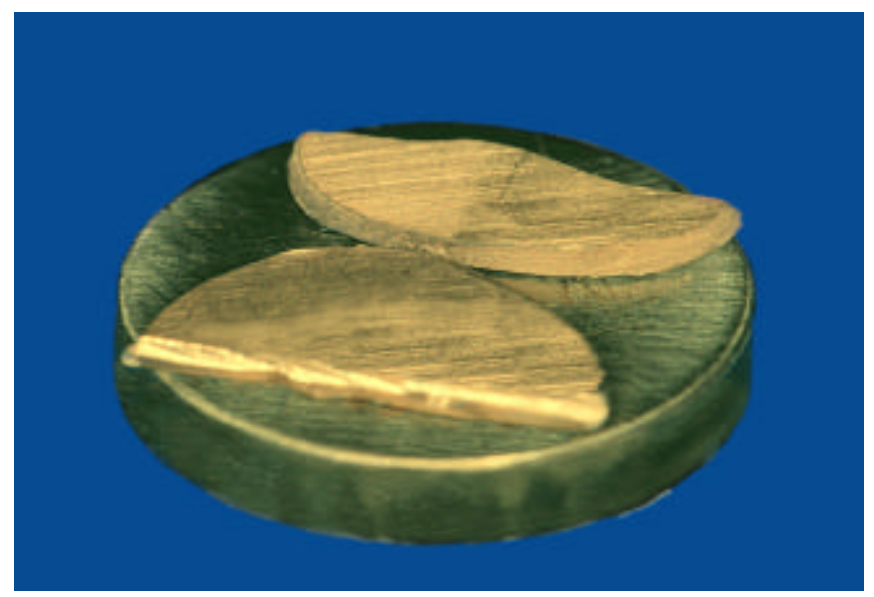

Figura 27 - Fragmentos externos do disco de dentina, montados no porta-amostra de alumínio e recobertos com ouro, para serem analisados no microscópio eletrônico de varredura.

Convém ressaltar que a cobertura com ouro foi executada em duas etapas. $\mathrm{Na}$ primeira, os fragmentos foram montados perpendicularmente à base do porta-amostras, com a área de fratura voltada em direção da saída da evaporação áurea. Na segunda etapa,

\footnotetext{
${ }^{32}$ Balzers, Germany.

${ }^{33}$ Balzers SDC 050, Germany.
} 
os espécimes foram acomodados paralelamente à base, permitindo que a superfície oclusal dos fragmentos dos discos de dentina fossem metalizadas.

\subsubsection{Obtenção das Imagens de MEV}

Foram obtidas quatro imagens da superfície de cada disco de dentina e outras quatro correspondentes às regiões da fratura, conforme a seqüência dos experimentos executada. Assim, as imagens foram capturadas da região da dentina coberta pela smear layer, da dentina após ser limpa com EDTA, outras após a aplicação dos materiais, e as últimas imagens foram obtidas dos segmentos dentinários que sofreram a seqüência completa dos experimentos, culminando com o desafio com ácido cítrico.

A fim de que as imagens fossem obtidas de regiões com padrões morfológicos semelhantes para cada condição superficial, a região selecionada para o registro da imagem foi sempre a meia distância entre o centro do disco e a junção amelodentinária, próxima à linha da fratura, tanto para as imagens da área de superfície quanto para a região de fratura.

Todas as imagens foram obtidas com 12.000 vezes de aumento e armazenadas digitalmente em CD-Room. Foram obtidas um total de 160 imagens, oito para cada espécime e duas para cada etapa da seqüência experimental, uma da superfície e outra da área fraturada.

\subsubsection{Análise dos Resultados de Microscopia Eletrônica de Varredura}

Mediante esse exame, observou-se o padrão da eventual deposição de cristais tanto na superfície dentinária, como na área de fratura, conforme os diferentes materiais antihiperestésicos estudados de acordo com a seqüência de execução dos experimentos na superfície oclusal dos discos de dentina. 
As imagens microscópicas foram transferidas para o programa de análise de imagens Image $\mathrm{Lab}^{34}$, armazenadas no formato BMP, permitindo o processamento e o cálculo de vários parâmetros. As oito imagens de cada um dos cinco espécimes de cada grupo foram agrupadas em quatro galerias, referentes a cada um dos materiais estudados.

As dimensões das imagens digitalizadas foram calibradas previamente, com as dimensões reais proporcionadas pelo microscópio eletrônico, determinando as dimensões do pixel em relação a cena real. Esse procedimento baseou-se na aquisição de uma imagem padrão com referências de distâncias conhecidas, representada pela barra de medida da própria imagem microscópica, obtendo-se as dimensões do pixel para aquela imagem, em micrometros. Assim, pôde-se também calcular e padronizar a área total das imagens a serem analisadas em $370 \mu \mathrm{m}^{2}$.

As estratégias para a análise das imagens da região da superfície dentinária e da região da fratura não foram as mesmas. A análise das imagens da região da superfície dentinária foi estabelecida conforme o padrão de obstrução canalicular, de maneira que a região não obstruída/desobstruída dos túbulos dentinários foi quantificada como uma percentagem da área total da imagem. Assim, a área não obstruída/desobstruída foi selecionada utilizando-se o recurso da segmentação da imagem, diferenciando os tons de cinza que compõem as diferentes estruturas a serem analisadas.

A informação visual obtida no processo de digitalização no ImageLab foi representada através do histograma de freqüências, que permite mostrar apenas a informação de intensidade da cor. As barras de intensidade, que compõem o histograma, variam em número de 0 a 256, sendo tanto maior a resolução da cor quanto maior for o número de barras (Figura 28).

\footnotetext{
${ }^{34}$ Softium Sistemas de Informática, São Paulo, Brasil.
} 
Como a imagem capturada no microscópio eletrônico de varredura estava em tons de cinza, os três histogramas $\mathrm{R}, \mathrm{G}$, e $\mathrm{B}$, que representam a quantidade de tons vermelho, verde ou azul da imagem, apareceram com a mesma distribuição, pois a cor foi formada pela combinação desses espectros. Portanto, como os três gráficos são iguais, pôde-se usar um único para representar a imagem.

Para fins ilustrativos e diferenciação das etapas de procedimento, a cor verde foi escolhida para demarcar os tons de cinza das regiões desobstruídas nas situações de dentina limpa com EDTA e das áreas não obstruídas pela smear layer, o azul para a análise do material e o vermelho para o desafio com ácido cítrico.

Assim que as fotomicrografias foram dispostas no programa, uma a uma para a análise, uma pequena região contendo o túbulo foi selecionada para a calibração dos tons de cinza que preenchem a região não obstruída/desobstruída dos túbulos dentinários a ser quantificada.

Para melhor definir, através dos tons de cinza, o que é superfície dentinária e o que é abertura tubular na imagem em maior aumento, além de utilizar a ferramenta do inverso da cor, o operador tenta definir o limite da cor que representa a estrutura através de tentativa e erro, aumentando e diminuindo os intervalos selecionados no histograma.

Assim que a região não obstruída/desobstruída da embocadura dos túbulos estiver preenchida pela marcação, dá-se o comando para a visualização completa da imagem com uma das cores vermelha, verde ou azul disponíveis, representando as regiões não obstruídas/desobstruídas dos túbulos dentinários a serem quantificadas (Figura 29). 


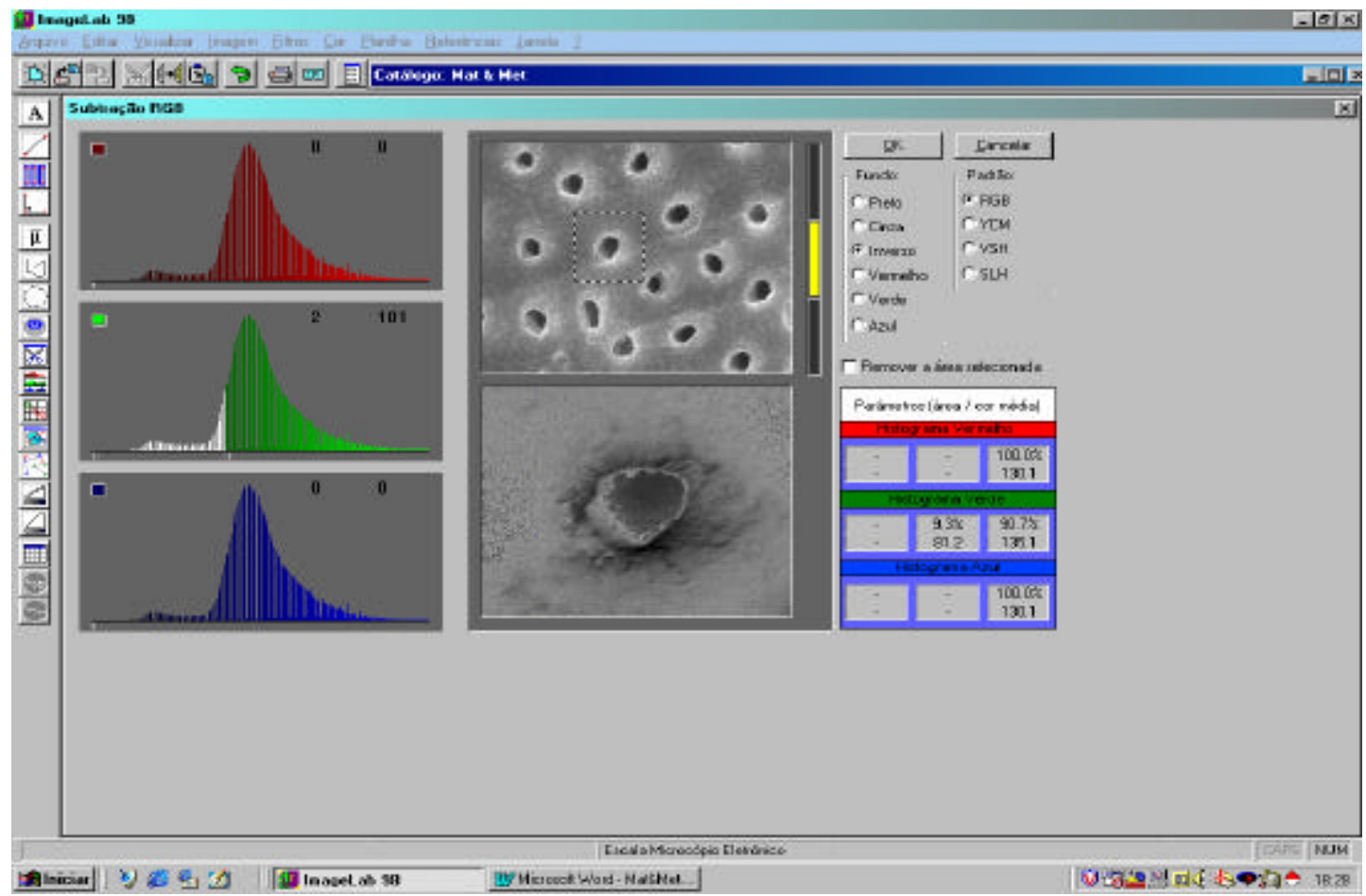

Figura 28 - Histograma de cores (à esquerda), imagem original (acima, à direita) e o resultado da segmentação utilizando tons de cinza para definir as áreas não obstruídas/desobstruídas dos túbulos dentinários (abaixo, à direita).

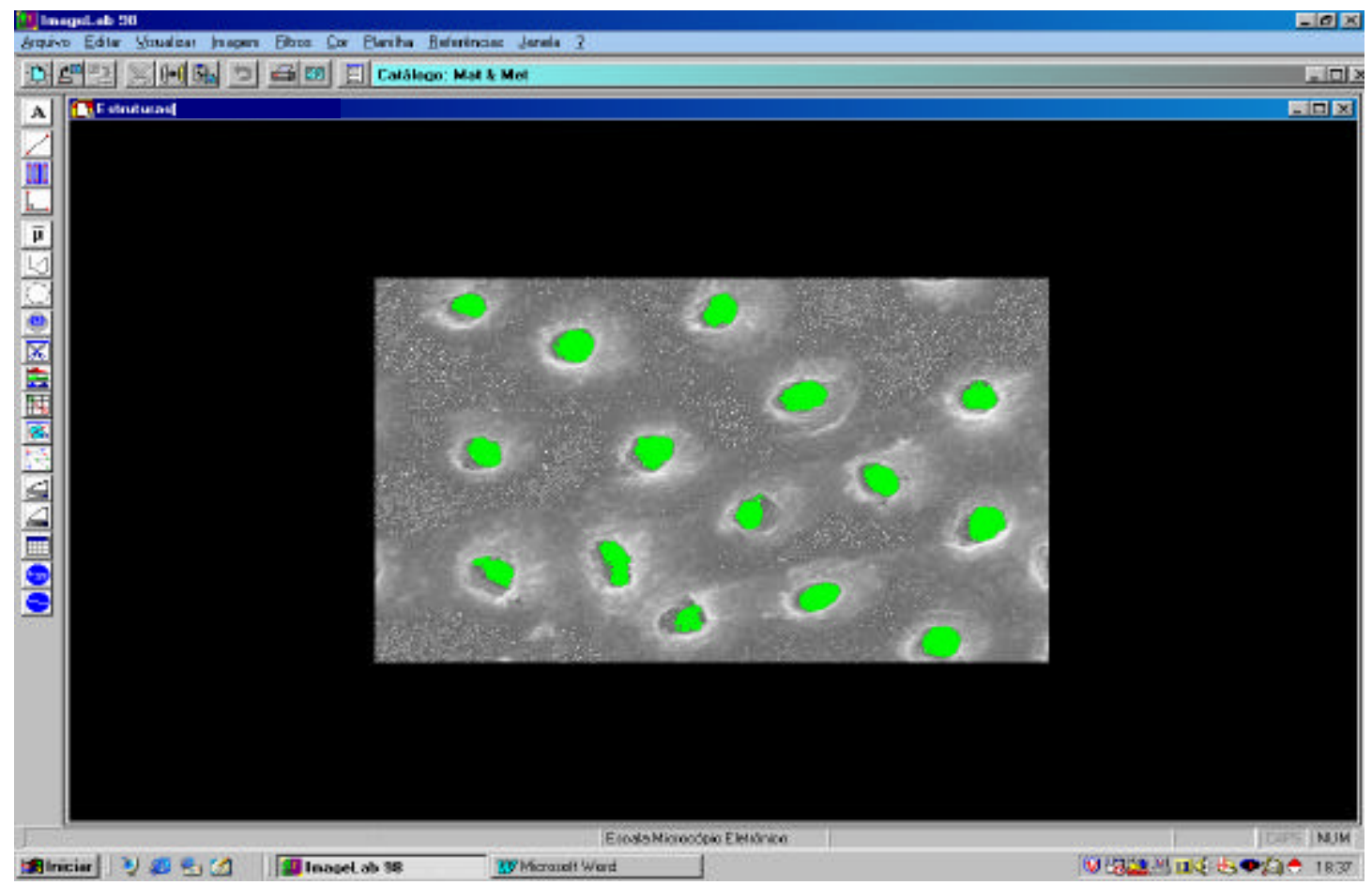

Figura 29 - Visualização da imagem das áreas não obstruídas/desobstruídas dos túbulos dentinários identificados automaticamente pelo computador. 
O programa efetua os cálculos requeridos na configuração e os apresenta na forma de uma planilha, fornecendo informações sobre a percentagem de regiões não obstruídas/desobstruídas em relação à área total da imagem, além de dados individuais e estatísticos sobre o número de túbulos, área e perímetro, medições de maior e menor diâmetro vistos em cada imagem (Figura 30).

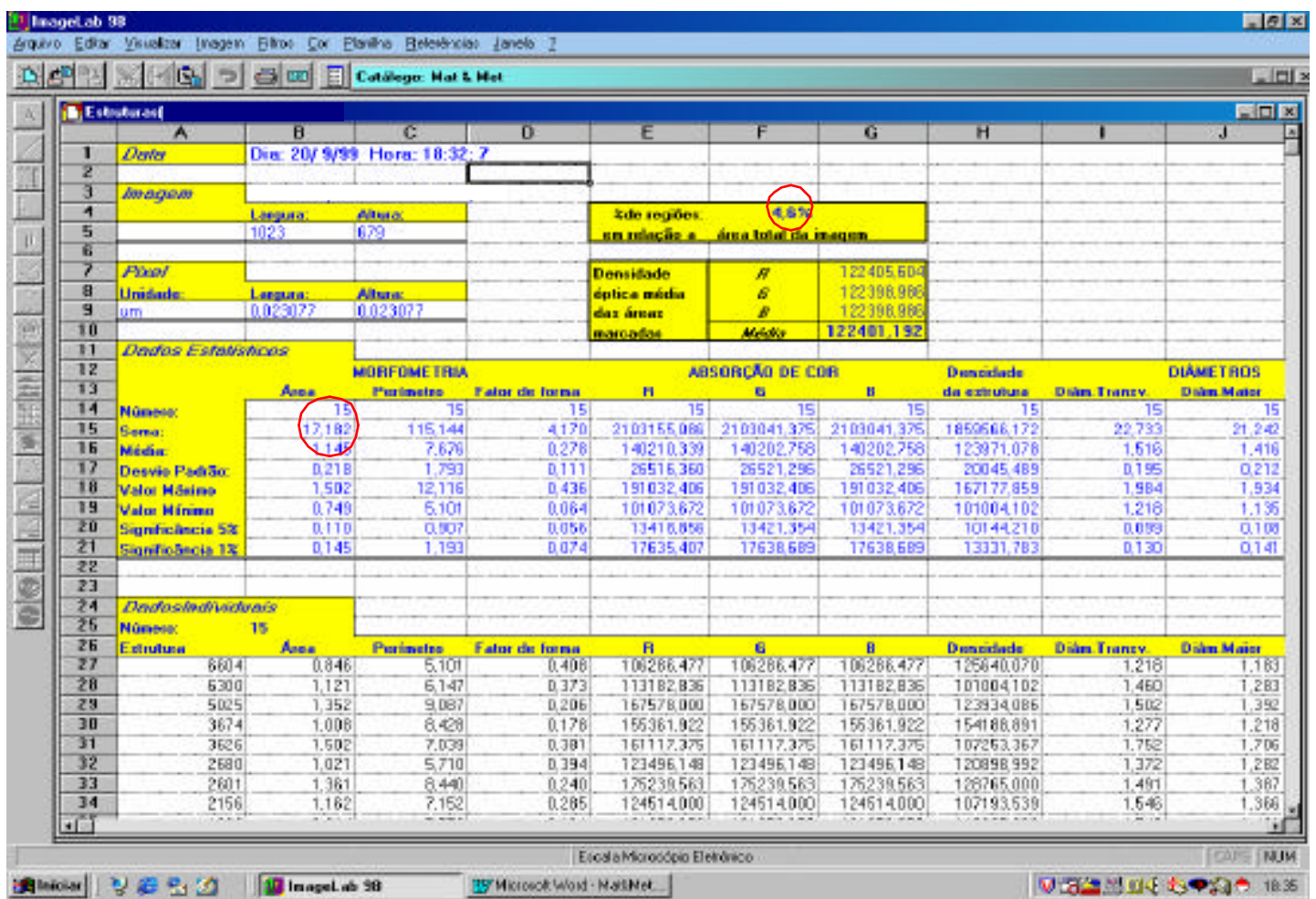

Figura 30 - Os cálculos efetuados são apresentados numa planilha que fornece uma variedade de informações sobre as áreas delimitadas no histograma.

Com esse recurso digital tornou-se possível minimizar a tendência à subjetividade, sempre presente quando se pretende qualificar ou quantificar resultados por intermédio do uso de imagens (Figura 31). 

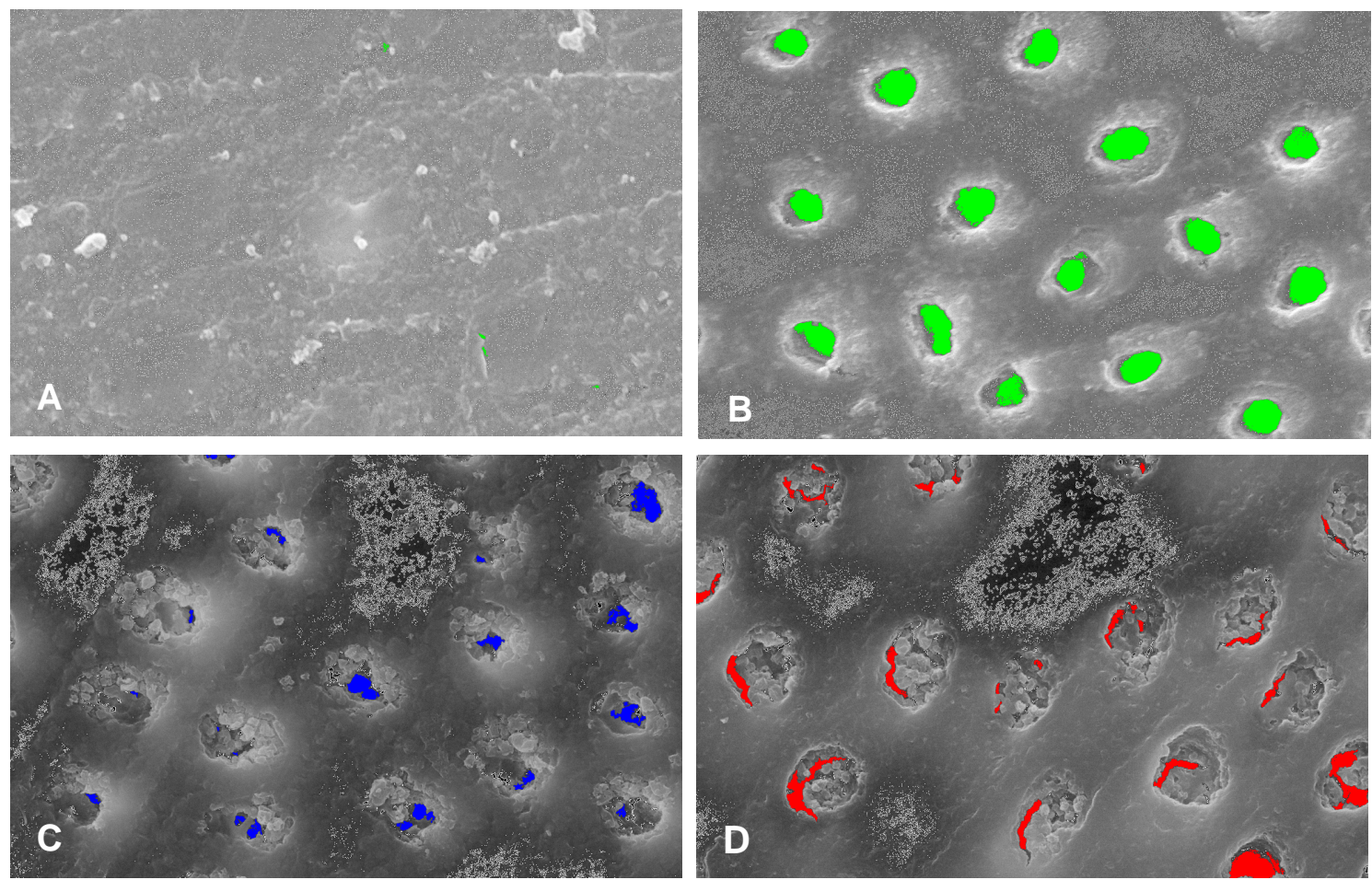

Figura 31 - Etapas da seqüência experimental executada: A - imagem característica da smear layer. Nota-se mínima área não obstruída demarcada com a cor verde; B - situação da dentina limpa com EDTA, cuja desobstrução canalicular foi também demarcada com verde; C regiões em azul representando as áreas não obstruídas após o tratamento da dentina com um dos materiais anti-hiperestésicos estudados; D - regiões desobstruídas após o desafio com ácido cítrico, delimitadas em vermelho.

As imagens da área fraturada de cada disco dentinário prestaram-se para fornecer, aproximadamente, até a que distância, no interior dos túbulos a partir da superfície, se estenderam os cristais, derivados dos agentes anti-hiperestésicos. A imagem era observada atentamente para que a formação cristalina mais profunda fosse detectada e, então, traçada a linha para medição da distância em micrometros, empregando-se ferramenta própria para definição de distâncias do ImageLab (Figura 32). 


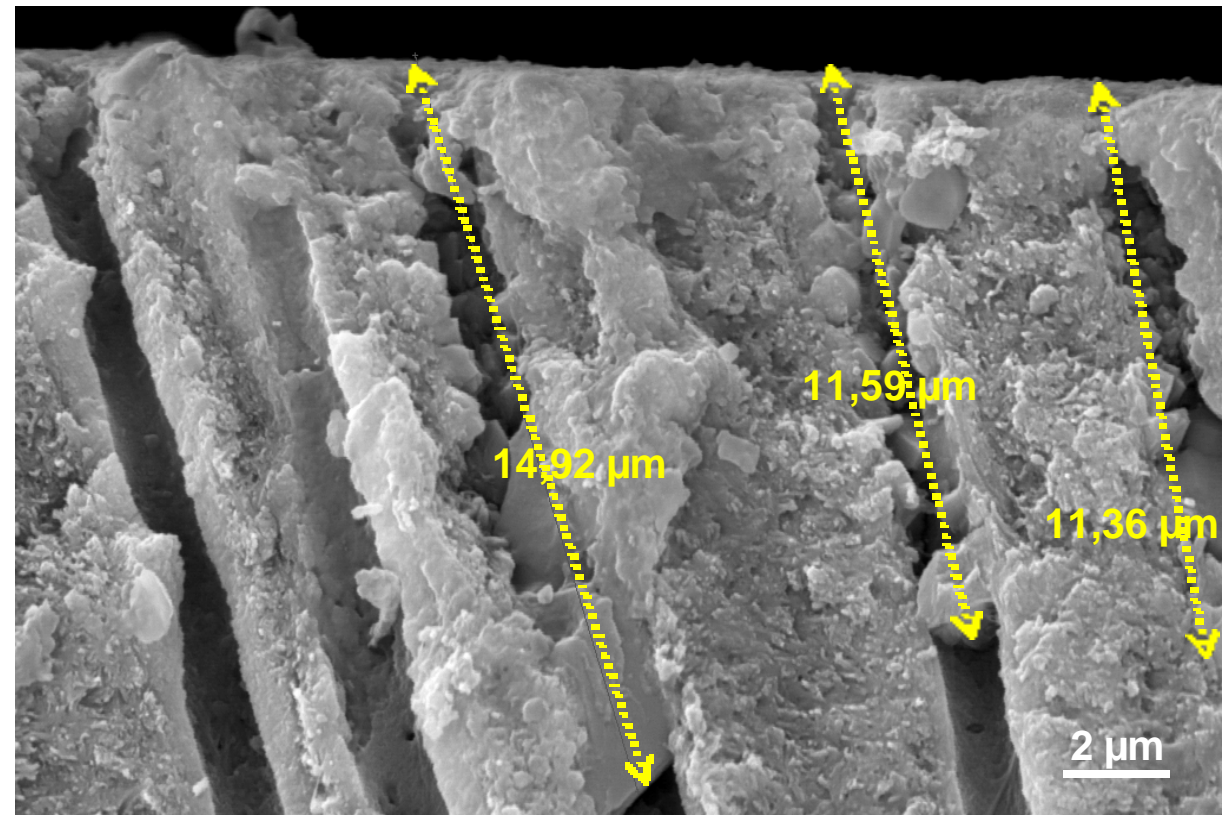

Figura 32 - Medição da profundidade alcançada pelos cristais, a partir da superfície, no interior dos túbulos.

\subsubsection{Planejamento Estatístico}

Como nos testes de condutividade hidráulica, para diminuir a variabilidade regional da dentina, os dados obtidos da análise de imagens das superfícies foram calculados como a mudança percentual da área não obstruída/desobstruída do túbulo dentinário após cada tratamento, em relação ao valor máximo de $100 \%$ de desobstrução obtido pelo EDTA, utilizando cada disco como seu próprio controle.

As médias e o desvio padrão das mudanças percentuais na percentagem de canalículos não obstruídos/desobstruídos foram calculados. As diferenças intergrupos foram identificadas empregando-se a análise de variância a um critério. As diferenças estatisticamente significantes entre os grupos foram rastreadas utilizando teste Múltiplo de Duncan. O mesmo teste foi utilizado para calcular as diferenças intragrupos. Para todos os testes convencionou-se o nível de significância de $5 \%(p<0,05)$.

A análise estatística foi realizada apenas sobre os dados obtidos da superfície dos espécimes. Os resultados apresentados para as imagens de fratura correspondem apenas às médias. 


\subsection{Execução da Microanálise de Raios $X$ por Espectroscopia de Energia Dispersiva (EDS)}

Para esta análise, foram utilizados dois discos de dentina para cada um dos quatro agentes anti-hiperestésicos, num total de oito espécimes. Os materiais foram aplicados na dentina condicionada, lavada, seca com ar, conforme as instruções do fabricante, abrangendo completamente a superfície oclusal dos discos. Esses discos foram preparados da mesma forma que para os ensaios de microscopia eletrônica de varredura, com exceção da cobertura da superfície que agora foi feita com uma camada condutora de aproximadamente $10 \mathrm{~nm}$ de espessura de carbono $^{32}$ termicamente evaporado em alta corrente $e^{33}$.

Procedeu-se à microanálise de energia dispersiva de raios $x^{35}$ pela emissão dos raios $\mathrm{X}$ a uma voltagem de $25 \mathrm{KV}$, a uma distância focal de $25 \mathrm{~mm}$, sob magnificação de mil vezes, pontualmente sobre um cristal ou aglomerado de cristais e na superfície dentinária livre de cristais. A análise englobou uma área superficial de $500 \mathrm{~nm}$, correspondente ao máximo diâmetro do feixe de elétrons, durante um tempo contínuo de cem segundos.

Basicamente, a microanálise de raios $X$ concentra-se no bombardeamento do espécime por um feixe de elétrons, provocando o deslocamento de elétrons dos átomos que compõem o espécime com a liberação de energia em forma de raios $X$. O sistema de detecção captura e discrimina os níveis de energia do raios $\mathrm{X}$, os quais são analisados por computador através do software Link $\operatorname{ISIS}^{36}$, fornecendo os espectros de raios $\mathrm{X}$. Determinado elemento sempre produzirá, invariavelmente, picos característicos em níveis específicos de energia, sendo a altura do pico proporcional ao teor do elemento capturado com uma sensibilidade em torno de $0,5 \%$. O software Link ISIS executou a análise qualitativa, identificando os elementos químicos do espécime, e semiquantitativa estimando

\footnotetext{
${ }^{35}$ Link Oxford EXL, England.

${ }^{36}$ Oxford Instruments, England.
} 
percentualmente o teor desses elementos. Os resultados são apresentados em forma de gráficos, cuja abcissa representa a intensidade (cps) e a ordenada, os níveis de energia $(\mathrm{keV})$.

\subsection{Ensaios de Difração de Raios X (XRD)}

Para os ensaios de difração de raios $X$ foram obtidas amostras de espécimes em duas diferentes apresentações: discos de dentina e pó de dentina.

Os 18 discos de dentina foram preparados da mesma maneira já descrita nos experimentos precedentes, sendo que em nove deles a smear layer foi simulada com lixa 320 , e os outros nove foram apenas limpos com EDTA. Essas condições superficiais que precedem a aplicação dos agentes anti-hiperestésicos foram executadas seguindo a seqüência de procedimentos empregada para os ensaios de condutibilidade e de microscopia eletrônica.

Um disco de cada condição, isto é, um limpo com EDTA e outro com a smear layer, foi reservado para controle. Cada material anti-hiperestésico foi aplicado em quatro espécimes de dentina seca com ar, dois durante três minutos e outros dois durante 12 minutos, um na dentina limpa e outro na dentina com smear layer, conforme a Tabela 4.

Tabela 4 - Distribuição da amostragem nos ensaios de difração de raios $X$, relacionando os agentes anti-hiperestésicos estudados e os espécimes em forma de disco ou pó de dentina.

\begin{tabular}{|c|c|c|c|c|c|c|}
\hline & \multicolumn{4}{|c|}{ Discos de Dentina } & \multirow{2}{*}{\multicolumn{2}{|c|}{ Pó de Dentina }} \\
\hline & \multicolumn{2}{|c|}{ Smear Layer } & \multicolumn{2}{|c|}{ EDTA } & & \\
\hline & 3 minutos & 12 minutos & 3 minutos & 12 minutos & 3 minutos & 12 minutos \\
\hline Oxa-Gel & 1 & 1 & 1 & 1 & 1 & 1 \\
\hline Experimental 1 & 1 & 1 & 1 & 1 & 1 & 1 \\
\hline Experimental 2 & 1 & 1 & 1 & 1 & 1 & 1 \\
\hline Gel Fluoretado & 1 & 1 & 1 & 1 & 1 & 1 \\
\hline Controle & 1 & 1 & & & & 1 \\
\hline
\end{tabular}


Os discos foram lavados com jatos indiretos de água deionizada por dez segundos e mantidos em recipientes individuais durante aproximadamente uma hora, até que a umidade fosse diminuída para que pudessem ser armazenados com sílica gel até o momento dos ensaios de difração de raios $\mathrm{X}^{37}$.

O pó de dentina foi preparado a partir da porção coronária de terceiros molares extraídos inclusos após a remoção do esmalte superficial, que foram deixados para desidratar durante dois dias. Uma prensa ${ }^{38}$ de dez toneladas reduziu os dentes à fragmentos menores que foram postos num triturador de bola ${ }^{39}$, funcionando por um período de cinco dias, até que estivessem completamente pulverizados e pudessem ser peneirados. $\mathrm{O}$ tamanho das partículas de dentina obtidas foi $420 \mu \mathrm{m}$, correspondente à peneira seriada ${ }^{40}$ mesh 35.

Aproximadamente cinco gramas de pó foram suficientes para compor cada uma das nove amostras estudadas: uma porção foi deixada sem tratar para controle, e outras duas foram reservadas para cada material, uma tratada durante três minutos e, outra, por 12 minutos. A mistura, depositada num funil analítico, foi filtrada a vácuo ${ }^{41}$ para a análise.

As amostras, depositadas sobre uma lâmina de vidro no interior do difratômetro (Figura 33) formando uma pastilha nas mesmas dimensões de um disco de dentina, foram bombardeadas por um feixe de raios $\mathrm{X}$ de alta ntensidade, aproximadamente $40 \mathrm{KV}$ e $40 \mathrm{~mA}$, durante um segundo. Variando-se o ângulo de incidência do feixe de raios $\mathrm{X}$, de 10 a $60^{\circ}$ 2è, através da rotação da amostra a uma velocidade predeterminada com um módulo de varredura contínuo, obteve-se o registro dos planos cristalográficos. A partir desse registro, uma análise comparativa com dados referência predeterminados pelo próprio aparelho fornece as fases presentes no material e apresenta os gráficos.

\footnotetext{
37 Siemens, Modelo D5000, Germany

38 Delfabro, Buenos Aires, Argentina.

${ }^{39}$ MLW KM 1, Wittenberg Lutherstadt, Germany.

${ }^{40}$ WS Wstyler Company, Ohio, USA.
} 

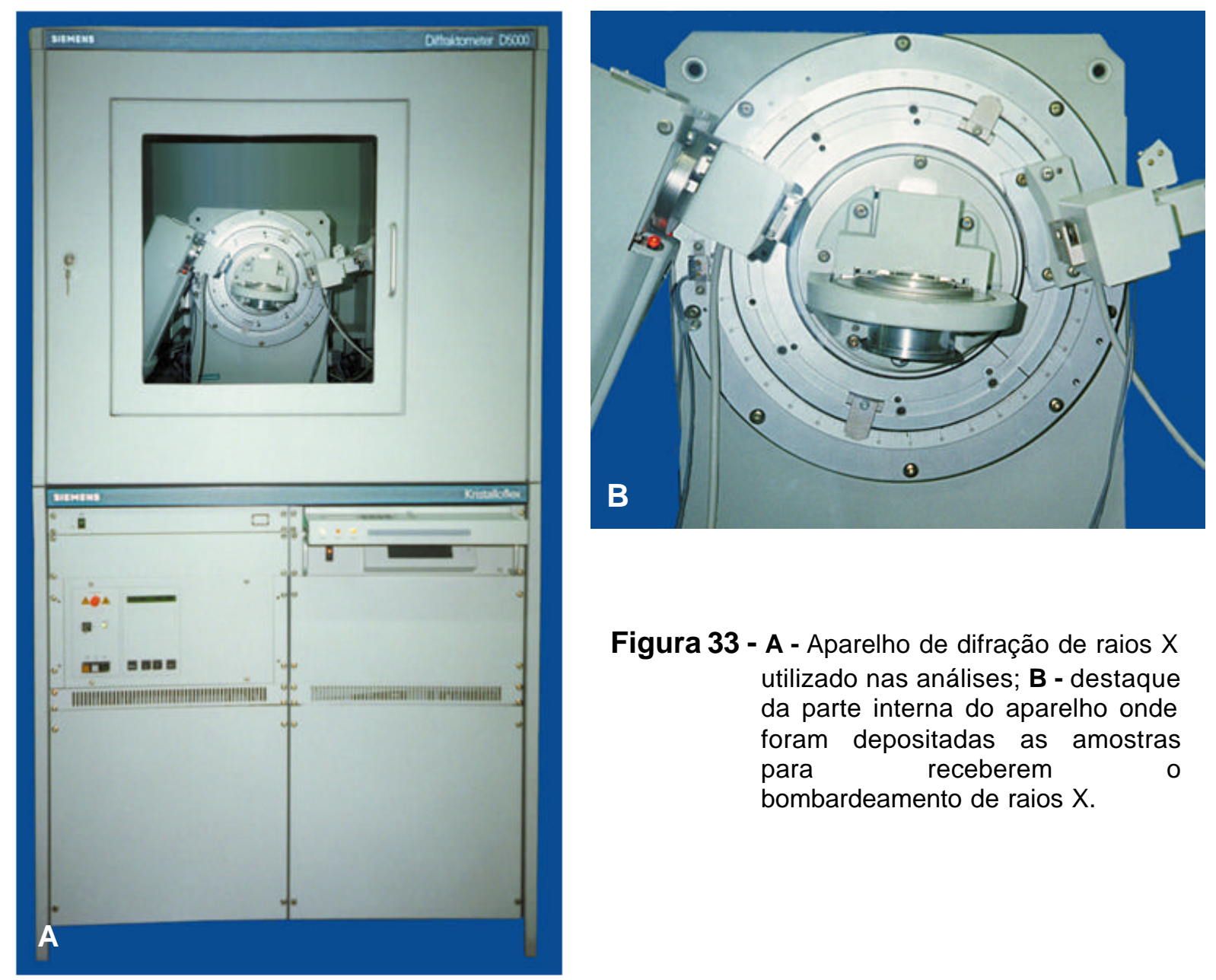

Figura 33 - A - Aparelho de difração de raios $X$ utilizado nas análises; $\mathbf{B}$ - destaque da parte interna do aparelho onde foram depositadas as amostras para receberem bombardeamento de raios $\mathrm{X}$.

${ }^{41}$ Procedimento realizado pelo laboratório do CCDM - UFSCar,, São Carlos, Brasil. 
Resultados 


\section{Resultados}

\subsection{Condutividade Hidráulica}

Os resultados dos ensaios de condutividade hidráulica foram analisados estatisticamente através da análise de variância a dois critérios, com nível de significância de $5 \%$, aplicada aos valores médios percentuais, identificando as diferenças intragrupos e intergrupos, sendo as diferenças individuais estatisticamente significantes rastreadas pelo teste Múltiplo de Duncan, também a um nível de significância de $5 \%$.

Os valores médios de condutividade hidráulica (Lp), expressos em percentagem, referentes ao comportamento da dentina frente aos quatro materiais com potencial antihiperestésico, sob as cinco condições de superfície, estão apresentados conforme a seqüência de experimentos executada. Assim, as médias e os respectivos desvios padrão de filtração do líquido através dos espécimes de dentina, acompanhados das significâncias estatísticas, logo após o condicionamento com EDTA, na presença da smear layer, imediatamente após a aplicação do material e, finalmente, seguido do desafio com ácido cítrico a $6 \%$, encontram-se nas Tabelas de 5 a 8 , respectivamente para o Oxa-Gel, Experimental 1, Experimental 2 e Gel Fluoretado.

Convém lembrar que os valores de permeabilidade obtidos quando a smear layer foi mantida traduzem a permeabilidade mínima de filtração e, logo após o condicionamento com o EDTA, representam o valor máximo de filtração, isto é, $100 \%$, individualmente, para cada espécime. Observa-se, também, que para todos os materiais e diante de todas as condições de pré-tratamento da superfície os valores de filtração obtidos na presença da smear layer, após a aplicação do material e após o desafio ácido são, em geral, significantemente menores do que os obtidos frente ao EDTA. 
Observa-se na Tabela 5 que sobre a dentina seca com ar o Oxa-Gel proporcionou um padrão médio de filtração, embora estatisticamente semelhante, numericamente inferior ao da smear layer. Após o desafio com ácido cítrico, o padrão de filtração foi significantemente mais elevado que os anteriores (Oxa-Gel e smear layer) mas, ainda assim, cerca de $65 \%$ menor que a filtração máxima.

Quando a dentina foi seca com papel absorvente, os valores médios de filtração tanto na presença da smear layer quanto após o desafio com ácido cítrico, foram estatisticamente semelhantes entre si e significantemente superiores à filtração de 14,4\%, observada após a aplicação do Oxa-Gel. Já na dentina molhada, a aplicação do Oxa-Gel proporcionou um índice de filtração de 10,3\%, ligeiramente superior, mas estatisticamente semelhante em relação ao observado na presença da smear layer e após condicionamento com ácido cítrico.

Quando a dentina foi previamente acidificada e seca com ar, o tratamento com OxaGel resultou numa filtração média de $38,5 \%$, numericamente superior mas não diferente estatisticamente do valor obtido na presença da smear layer. O desafio com ácido cítrico permitiu um aumento de quase $7 \%(45,3 \%)$ na filtração em relação ao Oxa-Gel, sem, no entanto, alcançar um valor estatisticamente diferente. Quando a dentina, também acidificada, foi seca com papel absorvente e tratada com Oxa-Gel, a média de filtração quase triplicou em relação àquela fornecida antes da remoção da smear layer (de 12,7\% para 33,5\%), acusando diferença estatisticamente significante. O efeito do ácido cítrico praticamente não alterou o padrão médio de filtração proporcionado pelo Oxa-Gel nesta condição (31\%), permanecendo com o valor quase $70 \%$ inferior ao valor máximo de filtração. 
Tabela 5 - Comparações intragrupos da condutividade hidráulica da dentina, expressas em percentagem, após tratamento com o Oxa-Gel, considerando as condições de prétratamento (Duncan, $\mathrm{p}<0,05$ ).

\begin{tabular}{|c|c|c|c|c|c|}
\hline & \multicolumn{5}{|c|}{ Oxa-Gel } \\
\hline & $\begin{array}{l}\text { Seca } \\
\text { com ar }\end{array}$ & $\begin{array}{c}\text { Seca } \\
\text { com papel }\end{array}$ & Molhada & $\begin{array}{l}\text { Acidificada e } \\
\text { seca com ar }\end{array}$ & $\begin{array}{l}\text { Acidificada e } \\
\text { seca com papel }\end{array}$ \\
\hline EDTA & 100,00 & 100,00 & 100,00 & 100,00 & 100,00 \\
\hline Smear Layer & $17,040 \pm 15,061$ & $29,026 \pm 11,372$ & $6,537 \pm 5,014$ & $31,819 \pm 18,447$ & $12,713 \pm 20,228$ \\
\hline Oxa-Gel & $10,593 \pm 6,738$ & $14,476 \pm 7,966$ & $10,317 \pm 5,013$ & $38,512 \pm 10,451$ & $|33,502 \pm 20,923|$ \\
\hline Ácido Cítrico & $34,895 \pm 15,061$ & $26,406 \pm 11,372$ & $9,649 \pm 5,014$ & $45,332 \pm 18,447$ & $|31,003 \pm 20,228|$ \\
\hline
\end{tabular}

Barras unem diferenças não significantes

Considerando o comportamento do Oxa-Gel na seqüência dos ensaios, para as condições em que a dentina foi condicionada, lavada e seca com ar, molhada e acidificada e seca com ar, as filtrações na presença da smear layer e após o emprego do Oxa-Gel mostraram-se estatisticamente semelhantes. Entretanto, o Oxa-Gel aplicado na dentina seca com ar, apesar de não se apresentar diferente estatisticamente, mostrou uma diminuição da filtração de $7 \%$ em relação à filtração na presença da smear layer. As condições da dentina, acidificada ou não, secas com papel absorvente, apresentaram diferenças significativas quando foram feitas as comparações entre smear layer e material. Nesse caso, observa-se que o fator da diferença é a condição de acidificação da dentina, já que a condição de apenas seca com papel absorvente manteve-se num nível de filtração cerca de $14 \%$ inferior ao da smear layer.

Nas condições molhada e acidificadas e secas com ar ou com papel absorvente, observou-se que o desafio ácido provocou valores de filtração estatisticamente semelhantes àqueles produzidos após a aplicação do Oxa-Gel. Já nos grupos em que a dentina não acidificada foi seca com ar ou com papel absorvente, o desafio ácido mostrou um aumento significante da filtração quando comparado com o Oxa-Gel. Ao mesmo tempo, as diferenças entre a percentagem de filtração na presença da smear layer e após o desafio ácido nos 
grupos onde a dentina foi seca com papel ou mantida molhada não foram consideradas significantes.

A Tabela 6 mostra os resultados da filtração referentes ao material Experimental 1. Observa-se nesta tabela que, exceto no grupo em que a dentina foi previamente acidificada e seca com papel, a percentagem de filtração proporcionada sob a ação do agente antihiperestésico foi estatisticamente semelhante à da smear layer. As percentagens de filtração foram, de fato, numericamente menores (14,5\% e $16,3 \%$, respectivamente) que as da smear layer para os grupos seca com ar ou molhada, embora não se tenham demonstrado estatisticamente diferentes. Esses valores representam percentuais de filtração respectivamente $85,5 \%$ e $83,7 \%$ menores que o da dentina não tratada (EDTA).

$\mathrm{Na}$ dentina seca com papel absorvente, a aplicação do agente Experimental 1 apresentou pequeno aumento dos valores de filtração quando comparados com a média de filtração na presença da smear layer, sem ser caracterizada uma diferença estatisticamente significante. O mesmo ocorreu após o desafio com ácido cítrico. Apesar de ter provocado um aumento de aproximadamente $7 \%$ na filtração, essa diferença não foi considerada significante quando comparada com o valor médio de filtração obtido após a aplicação do Experimental 1. O valor médio de filtração alcançado após o condicionamento com ácido cítrico foi de $11,6 \%$ a mais que o obtido na presença da smear layer, sendo essa diferença significante estatisticamente.

Quando a dentina foi acidificada e seca com ar, o gel Experimental 1, proporcionou valor médio de filtração de $26,1 \%$, estatisticamente semelhante ao obtido quando a smear layer foi mantida, embora razoavelmente superior a esta numericamente. Entretanto, quase duplicou após a atuação do ácido cítrico, acusando diferença estatisticamente significante quando comparado aos valores médios da smear layer e do gel Experimental 1 
Tabela 6 - Comparações intragrupos da condutividade hidráulica da dentina, expressas em percentagem, após tratamento com o material Experimental 1, considerando as condições de pré-tratamento (Duncan, $p<0,05$ ).

\begin{tabular}{|c|c|c|c|c|c|}
\hline \multicolumn{6}{|c|}{ Experimental 1} \\
\hline & $\begin{array}{l}\text { Seca } \\
\text { com ar }\end{array}$ & $\begin{array}{c}\text { Seca } \\
\text { com papel }\end{array}$ & Molhada & $\begin{array}{l}\text { Acidificada e } \\
\text { seca com ar }\end{array}$ & $\begin{array}{c}\text { Acidificada e } \\
\text { seca com papel }\end{array}$ \\
\hline EDTA & 100,00 & 100,00 & 100,00 & 100,00 & 100,00 \\
\hline Smear Layer & $17,857 \pm 18,010$ & $14,037 \pm 12,427$ & $17,350 \pm 7,795$ & $\mid 17,864 \pm 17,985$ & $8,563 \pm 6,054$ \\
\hline Experimental 1 & $14,538 \pm 11,402$ & $18,714 \pm 9,958$ & $16,322 \pm 7,414$ & $26,126 \pm 8,140$ & $14,561 \pm 7,143$ \\
\hline Ácido Cítrico & $19,250 \pm 18,010$ & $25,676 \pm 12,427$ & $17,293 \pm 7,795$ & $44,700 \pm 17,985$ & $12,585 \pm 6,054 \|$ \\
\hline
\end{tabular}

Barras unem diferenças não significantes

A dentina acidificada e seca com papel absorvente, quando tratada com o agente Experimental 1, mostrou um padrão médio de filtração de $14,5 \%$, estatisticamente superior ao da smear layer e semelhante à filtração provocada pelo ácido cítrico. A filtração de $12,5 \%$ após o desafio ácido foi considerada estatisticamente semelhante ao valor médio de filtração de $8,5 \%$, permitido pela barreira da smear layer.

Nas condições em que a dentina foi seca com ar e com papel absorvente, molhada e acidificada e seca com papel absorvente, a comparação dos valores de filtração após o tratamento com o Experimental 1 com os valores após o desafio com ácido cítrico não proporcionou diferenças estatisticamente significantes. Entretanto, os valores numéricos indicaram o aumento da filtração após o desafio ácido para as condições da dentina seca com ar, com papel absorvente e molhada. A filtração manteve-se semelhante estatisticamente para as condições seca com ar, molhada e acidificada e seca com papel, quando a comparação se deu entre a filtração na presença da smear layer e após ao desafio ácido. 
A Tabela 7 relaciona os valores obtidos com 0 material Experimental 2. Os percentuais de filtração apresentados nessa tabela mostram-se com pouca variabilidade quando se comparam os resultados da smear layer com os do agente anti-hiperestésico. Independentemente do grupo de pré-tratamento da dentina, o agente Experimental 2 proporcionou valores de filtração muito próximos dos da smear layer, semelhança essa confirmada estatisticamente. Essa tendência prosseguiu após o desafio ácido, exceto para o grupo em que a dentina foi previamente acidificada e seca com ar. Nesse caso, o índice de filtração foi cerca de $10 \%$ maior que aqueles obtidos na presença da smear layer (15,7\%) e do agente Experimental 2 (16,3\%). Observa-se, ainda, que na dentina mais acidificada os valores de filtração após o tratamento com o agente Experimental 2 foram sempre numericamente menores que os da smear layer e com pequena variabilidade mesmo após o desafio ácido. Contudo, foi na dentina molhada que o agente Experimental 2 permitiu a menor filtração de líquido em relação às outras condições de pré-tratamento superficial (4,3\%). O emprego do ácido cítrico praticamente não modificou o valor da filtração, ainda cerca de $2 \%$ inferior ao obtido na presença da smear layer.

Tabela 7-Comparações intragrupos da condutividade hidráulica da dentina, expressas em percentagem, após tratamento com o material Experimental 2, considerando as condições de pré-tratamento (Duncan, $\mathrm{p}<0,05$ ).

\begin{tabular}{l|c|c|c|c|c|}
\multicolumn{5}{c}{} & \multicolumn{5}{c}{ Experimental 2 } \\
\cline { 2 - 6 } & $\begin{array}{c}\text { Seca } \\
\text { com ar }\end{array}$ & $\begin{array}{c}\text { Seca } \\
\text { com papel }\end{array}$ & Molhada & $\begin{array}{c}\text { Acidificada e } \\
\text { seca com ar }\end{array}$ & $\begin{array}{c}\text { Acidificada e } \\
\text { seca com papel }\end{array}$ \\
EDTA & 100,00 & 100,00 & 100,00 & 100,00 & 100,00 \\
\cline { 2 - 7 } Smear Layer & $15,142 \pm 17,578$ & $16,552 \pm 16,877$ & $6,508 \pm 3,340$ & $15,723 \pm 18,291$ & $10,072 \pm 13,062$ \\
Experimental 2 & $12,355 \pm 12,222$ & $15,399 \pm 8,811$ & $4,331 \pm 3,244$ & $16,379 \pm 8,476$ & $10,158 \pm 9,543$ \\
\cline { 2 - 7 } Ácido Cítrico & $16,421 \pm 17,578$ & $19,437 \pm 16,877$ & $4,304 \pm 3,340$ & $26,975 \pm 18,291$ & $11,975 \pm 13,062$ \\
\cline { 2 - 6 }
\end{tabular}


Os valores de filtração proporcionados pelo Nupro Acidulated Gel a 1,23\%, ou Gel Fluoretado, estão apresentados na Tabela 8. Essa tabela proporciona uma visão geral bastante clara do desempenho do Gel Fluoretado na redução da permeabilidade da dentina. Pode-se observar que, independentemente do pré-tratamento da dentina, os percentuais de filtração foram sempre significantemente maiores que aqueles registrados na presença da smear layer, demonstrando baixa capacidade obstrutiva do Gel Fluoretado. No grupo da dentina seca com ar, o percentual de filtração foi de $41,4 \%$, ou seja, $29,3 \%$ maior que o da smear layer. Essas diferenças são ainda maiores nos outros grupos, especificamente na dentina acidificada e seca com papel absorvente, onde o percentual de filtração foi de $72,2 \%$ após o tratamento com o Gel Fluoretado, 61,6\% maior que o da smear layer. A despeito dessa tendência marcante, o desafio ácido não produziu alterações significantes na filtração nos grupos em que a dentina foi seca com ar, com papel absorvente ou mantida molhada. Mesmo nos grupos restantes, onde ocorreu diferença estatística, o desafio ácido proporcionou valores numéricos de filtração muito próximos daqueles observados após o tratamento com o Gel de Flúor.

Tabela 8 - Comparações intragrupos da condutividade hidráulica da dentina, expressas em percentagem, após tratamento com o Gel Fluoretado, considerando as condições de prétratamento (Duncan, $\mathrm{p}<0,05$ ).

\begin{tabular}{|c|c|c|c|c|c|}
\hline \multicolumn{6}{|c|}{ Gel Fluoretado } \\
\hline & $\begin{array}{l}\text { Seca } \\
\text { com ar }\end{array}$ & $\begin{array}{c}\text { Seca } \\
\text { com papel }\end{array}$ & Molhada & $\begin{array}{l}\text { Acidificada e } \\
\text { seca com ar }\end{array}$ & $\begin{array}{l}\text { Acidificada e } \\
\text { seca com papel }\end{array}$ \\
\hline EDTA & 100,00 & 100,00 & 100,00 & 100,00 & 100,00 \\
\hline Smear Layer & $12,493 \pm 19,708$ & $24,088 \pm 17,918$ & $16,497 \pm 19,296$ & $25,806 \pm 9,292$ & $10,605 \pm 16,226$ \\
\hline Gel Fluoretado & $41,472 \pm 14,438$ & | $62,890 \pm 14,599 \mid$ & $73,242 \pm 16,406$ & $77,474 \pm 8,227$ & $72,272 \pm 14,210$ \\
\hline Ácido Cítrico & $49,659 \pm 19,708$ & $70,283 \pm 17,918$ & $75,772 \pm 19,296$ & $67,327 \pm 9,292$ & $82,264 \pm 16,226$ \\
\hline
\end{tabular}

Barras unem diferenças não significantes 
Os Gráficos de 1 a 4 complementam a compreensão da tendência de comportamento dos diferentes materiais estudados, conforme a condição de pré-tratamento da dentina. Esses gráficos confirmam a menor variabilidade dos resultados obtidos com o material Experimental 2 nas diferentes condições de pré-tratamento.

Gráfico 1 - Valores médios de filtração, em percentagem, na presença da smear layer, após o tratamento com o Oxa-Gel e após o desafio ácido, sob os diferentes pré-tratamentos da dentina (Duncan, $p<0,05$ ).

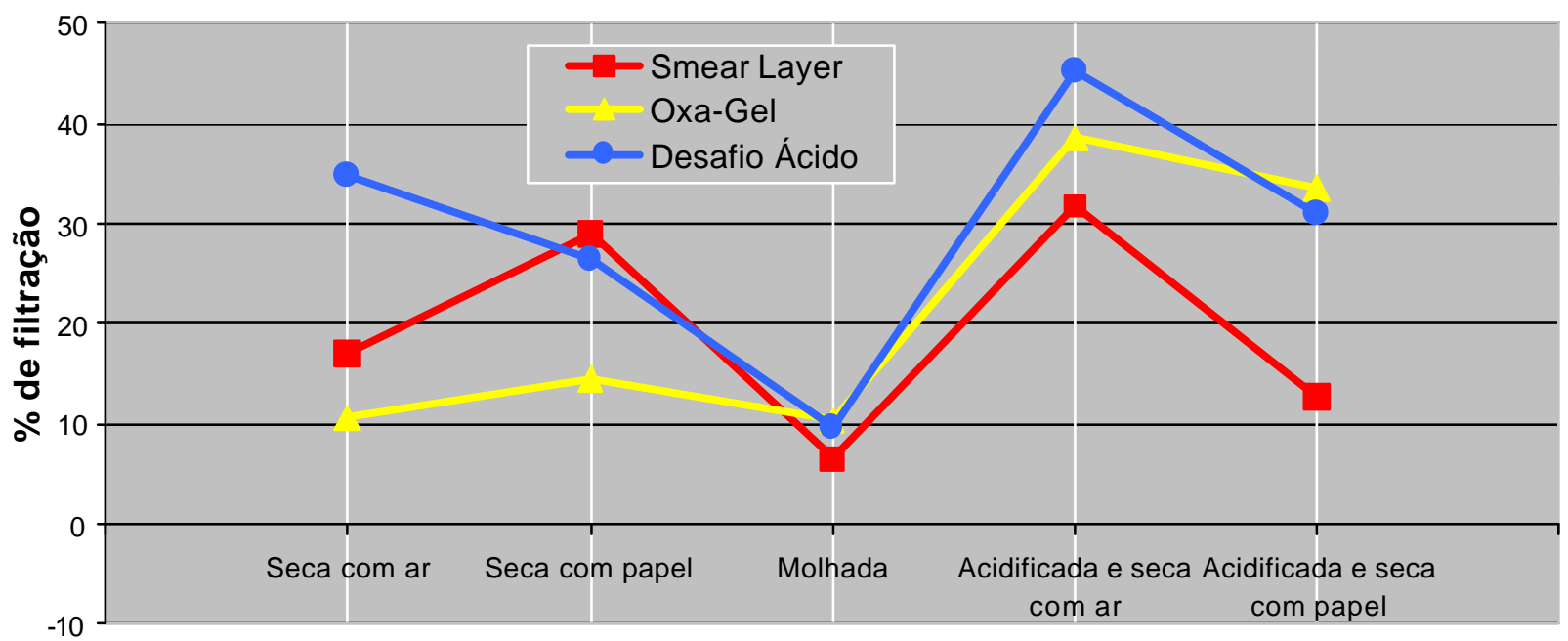

Oxa-Gel

Gráfico 2 - Valores médios de filtração, em percentagem, na presença da smear layer, após o tratamento com o material Experimental 1 e após o desafio com ácido cítrico, sob os diferentes pré-tratamentos da dentina (Duncan, $p<0,05$ ).

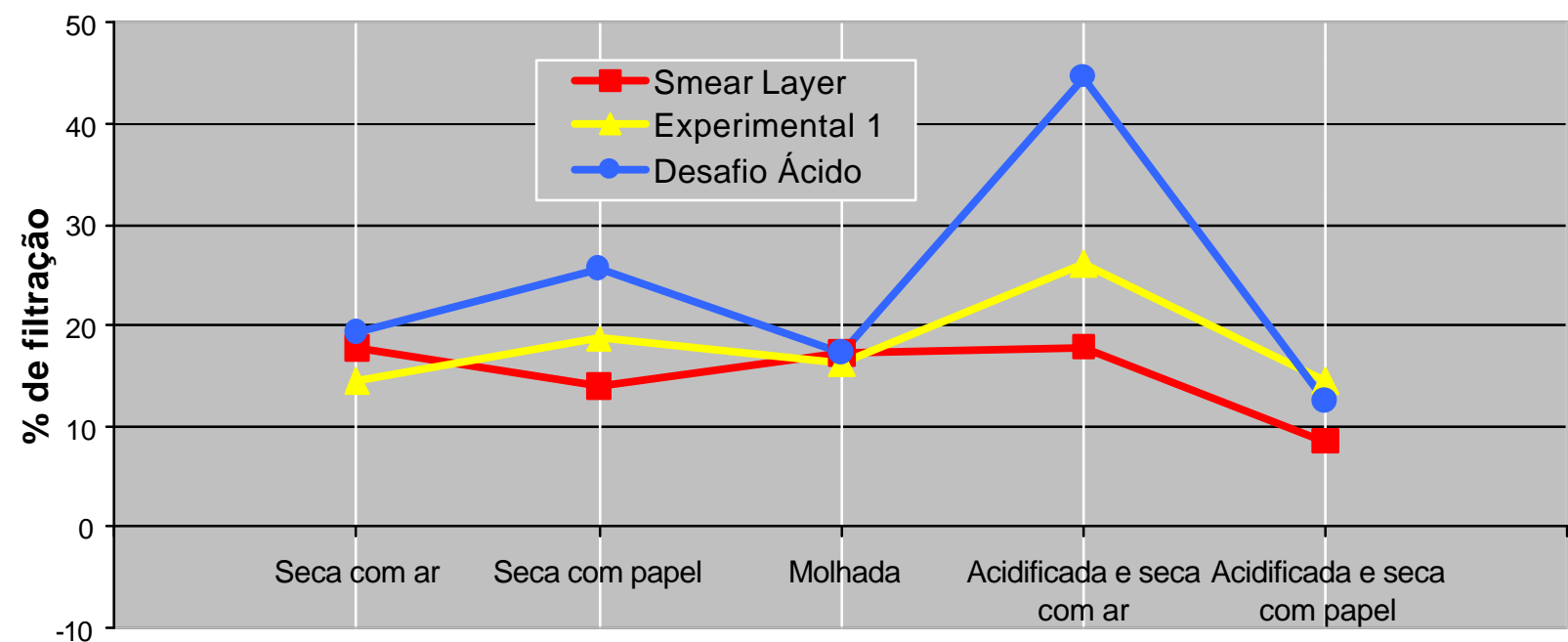

Experimental 1 
Gráfico 3 - Valores médios de filtração, em percentagem, na presença da smear layer, após o tratamento com o material Experimental 2 e após o desafio ácido, sob os diferentes prétratamentos da dentina (Duncan, $p<0,05$ ).

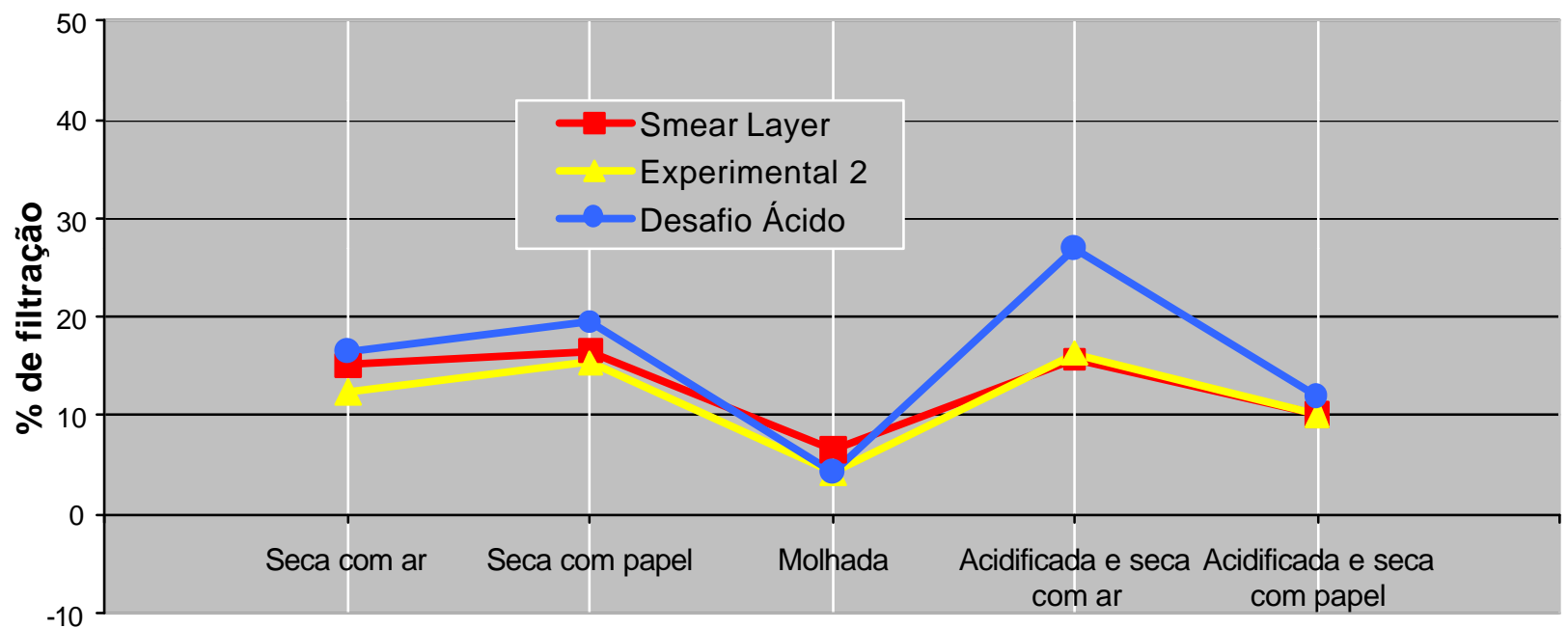

Experimental 2

Gráfico 4 - Valores médios de filtração, em percentagem, na presença da smear layer, após o tratamento com o Gel Fluoretado e após o desafio ácido, sob os diferentes pré-tratamentos da dentina (Duncan, $p<0,05$ ).

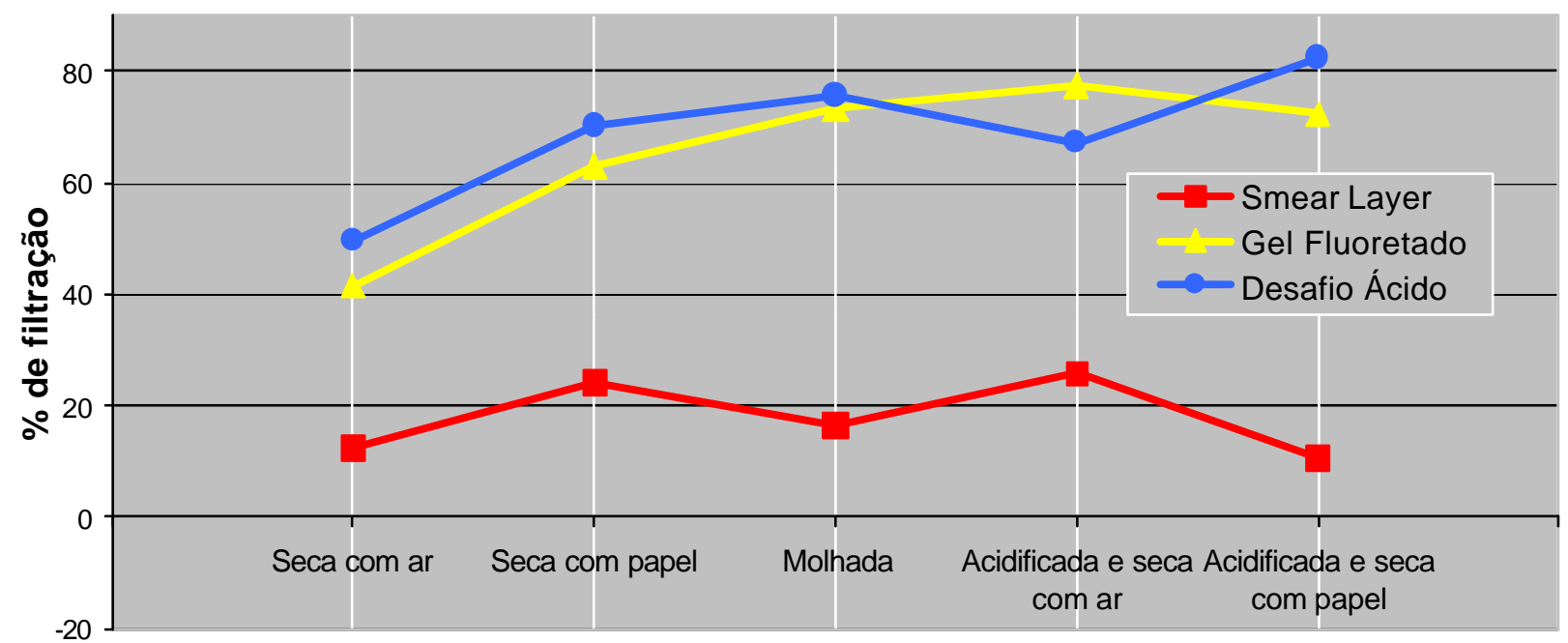

Gel Fluoretado

Para melhor entendimento do potencial obstrutivo de cada material estudado, desenvolveu-se a Tabela 9. Essa tabela expressa as diferenças e a significância estatística do efeito dos agentes estudados quando confrontados com os valores de filtração na presença da smear layer e após o desafio ácido. 
Tabela 9 - Diferença entre os valores médios de filtração, em percentagem, na presença da smear layer e após o tratamento com os materiais, e entre o tratamento com os materiais e 0 desafio ácido, sob os diferentes pré-tratamentos da dentina (Duncan, $p<0,05$ ).

\begin{tabular}{|c|c|c|c|c|c|c|c|c|c|c|c|}
\hline \multirow[b]{3}{*}{ Oxa-Gel } & \multicolumn{2}{|c|}{$\begin{array}{l}\text { Seca } \\
\text { com ar }\end{array}$} & \multicolumn{2}{|c|}{$\begin{array}{c}\text { Seca } \\
\text { com papel }\end{array}$} & \multicolumn{3}{|c|}{ Molhada } & \multicolumn{2}{|c|}{$\begin{array}{l}\text { Acidificada e } \\
\text { seca com ar }\end{array}$} & \multicolumn{2}{|c|}{$\begin{array}{c}\text { Acidificada e } \\
\text { seca com papel }\end{array}$} \\
\hline & \multicolumn{2}{|c|}{$\begin{array}{c}\text { smear desafio } \\
\text { material }\end{array}$} & \multicolumn{2}{|c|}{$\begin{array}{c}\text { smear desafio } \\
\text { material }\end{array}$} & \multicolumn{3}{|c|}{$\begin{array}{c}\text { smear desafio } \\
\text { material }\end{array}$} & \multicolumn{2}{|c|}{$\begin{array}{c}\text { smear desafio } \\
\text { material }\end{array}$} & \multicolumn{2}{|c|}{$\begin{array}{c}\text { smear desafio } \\
\text { material }\end{array}$} \\
\hline & \multicolumn{2}{|c|}{$17,0410,5934,89$} & \multicolumn{2}{|c|}{$29,0214,4726,40$} & \multicolumn{2}{|c|}{$6,53 \quad 10,31$} & 9,64 & \multicolumn{2}{|c|}{$31,8138,5145,33$} & \multicolumn{2}{|c|}{$12,7133,5031,00$} \\
\hline Diferença & 6,447 & $-24,302$ & $14,550^{*}$ & $-11,934$ & $-3,78 c$ & & 0,668 & $-6,693$ & $-6,82$ & $-20,789^{*}$ & 2,499 \\
\hline Experimental 1 & \multicolumn{2}{|c|}{$117,8514,5319,25$} & \multicolumn{2}{|c|}{$14,0318,7125,67$} & \multicolumn{3}{|c|}{ 17,35 16,32 17,29 } & \multicolumn{2}{|c|}{$17,8626,1244,70$} & \multicolumn{2}{|c|}{$\begin{array}{lll}8,56 & 14,56 & 12,58\end{array}$} \\
\hline Diferença & 3,319 & $-4,712$ & $-4,677$ & $-6,962$ & \multicolumn{3}{|c|}{1,028} & $-8,262$ & $-18,574$ & $-5,998^{*}$ & 1,976 \\
\hline Experimental 2 & \multicolumn{2}{|c|}{$215,1412,3516,42$} & \multicolumn{2}{|c|}{$16,5515,3919,43$} & \multicolumn{2}{|c|}{$6,50 \quad 4,33$} & 4,30 & \multicolumn{2}{|c|}{$15,7216,3726,97$} & \multicolumn{2}{|c|}{$10,07 \quad 10,1511,97$} \\
\hline Diferença & 2,780 & $-4,066$ & 1,153 & $-4,038$ & 2,177 & & 0,027 & $-0,656$ & $-10,596$ & $-0,086$ & $-1,817$ \\
\hline Gel Fluoretado & 12,4941, & 4749,65 & 24,0862 & 8970,28 & 16,497 & 73,24 & 475,77 & $25,8077,4$ & 4767,32 & 10,6072, & 2782,26 \\
\hline Diferença & $-28,979^{*}$ & $-8,187$ & $-38,802^{*}$ & $-7,393$ & $-56,745$ & $45^{*}$ & $-2,53$ & $-51,668^{*}$ & 10,147 & $-61,667^{*}$ & $-9,992$ \\
\hline
\end{tabular}

*Diferenças estatisticamente significantes

Na Tabela 10 estão os valores médios de filtração, considerando-se o material antihiperestésico como efeito principal, ou seja, independente da condição de pré-tratamento de superfície sobre o qual foram aplicados. Esses valores mostram que o Oxa-Gel e o gel Experimental 1 são estatisticamente semelhantes. Os géis, Experimental 2 e Fluoretado, mostraram diferenças estatisticamente significantes quando comparados entre si e aos demais. Contudo, o menor valor de filtração foi de 11,7\%, provocado pelo gel Experimental 2, considerando-o como efeito principal.

Quando os valores médios de filtração, após a aplicação dos géis, foram comparados aos obtidos na presença da smear layer, observou-se que apenas o gel Experimental 2 provocou decréscimo, mesmo que mínimo, na filtração. Enquanto o gel Experimental 1 e o Oxa-Gel aumentaram minimamente a condutividade hidráulica, o Gel Fluoretado aumentou a filtração em quase quatro vezes o seu valor na presença da smear layer. 
Tomando os pré-tratamentos de superfície como efeito principal, independentemente de que material foi utilizado, as atuações da dentina seca com papel absorvente e da dentina molhada foram consideradas estatisticamente semelhantes entre si, assim como foram as condições em que as superfícies dentinárias, previamente acidificadas ou lavadas, foram secas com papel absorvente. As superfícies dentinárias secas com ar, acidificadas ou não, mostraram-se diferentes entre si e das demais condições, sendo que a primeira (acidificada e seca com ar), proporcionou a maior filtração através da dentina dentre as condições estudadas, e a segunda foi a que mais restringiu a filtração. Todas as condições de prétratamento da dentina permitiram maior filtração quando comparadas à filtração na presença da smear layer. Entretanto, o percentual de filtração mostrado pela dentina seca com ar é bem próximo daquele proporcionado pela smear layer.

Tabela 10 - A - Efeito dos agentes anti-hiperestésicos na condutividade hidráulica da dentina, em percentagem, com relação ao pré-tratamento da superfície (Duncan, $p<0,05$ ).

B - Efeito do pré-tratamento da superfície na condutividade hidráulica da dentina, em percentagem, com relação aos agentes anti-hiperestésicos (Duncan, $p<0,05$ ).

\begin{tabular}{|c|c|c|c|c|c|}
\hline \multicolumn{3}{|c|}{ A - Efeito principal - MATERIAL } & \multicolumn{3}{|c|}{ B - Efeito principal - SUPERFÍCIE } \\
\hline & Média $\pm S D$ & near Layer & & Média $\pm S D$ & Smear Layer \\
\hline Oxa-Gel & $21,480 \pm 10,218$ & 19,427 & Seca com ar & $19,739 \pm 11,200$ & 15,633 \\
\hline Experimental 1 & $18,052 \pm 8,811$ & 15,134 & Seca com papel & $27,869 \pm 10,333$ & 20,925 \\
\hline Experimental 2 & $11,724 \pm 8,459$ & 12,799 & Molhada & $26,053 \pm 8,018$ & 11,723 \\
\hline \multirow[t]{2}{*}{ Gel Fluoretado } & $65,470 \pm 13,576$ & 17,897 & $\begin{array}{l}\text { Acidificada e } \\
\text { seca com ar }\end{array}$ & $39,622 \pm 8,823$ & 22,803 \\
\hline & & & $\begin{array}{l}\text { Acidificada e } \\
\text { seca com papel }\end{array}$ & $32,624 \pm 12,954$ & 10,488 \\
\hline
\end{tabular}

Barras unem diferenças não significantes

A Tabela 11 revela que, quanto ao comportamento intergrupos dos agentes antihiperestésicos, o Oxa-Gel produziu efeitos significantemente semelhantes aos valores médios de filtração quando aplicado sobre as superfícies dentinárias secas com ar (10,5\%), 
papel absorvente $(14,4 \%)$ e molhada $(10,5 \%)$. Também semelhantes estatisticamente foram os efeitos entre as superfícies acidificadas, entretanto, significantemente diferentes dos demais pré-tratamentos superficiais por filtrarem até três vezes mais líquido do que aqueles.

Para o gel Experimental 1, o valor da filtração na condição da dentina acidificada e seca com ar foi superior estatisticamente às demais $(26,1 \%)$, as quais variaram entre $14,5 \%$ e $18,7 \%$.

Os valores médios das filtrações após a aplicação do gel Experimental 2, sob as condições de dentina acidificada e seca com ar e de dentina molhada, 16,3\% e 4,3\%, respectivamente, mostraram-se diferentes estatisticamente. No entanto, são semelhantes estatisticamente às outras condições, cujos valores de filtração variaram de $10,1 \%$ até 15,3\%. Esses valores confirmam a pequena variabilidade nas percentagens de filtração proporcionada pelo gel Experimental 2, nas diferentes condições de pré-tratamento, conforme foi sugerido anteriormente.

Finalmente, o Gel Fluoretado produziu efeitos estatisticamente semelhantes entre as condições de superfície molhada e as acidificadas, secas com ar e com papel absorvente, todas permitindo uma filtração superior a $70 \%$. As superfícies secas com papel absorvente, acidificadas ou não, também mostraram-se semelhantes, porém estatisticamente diferentes das demais. A superfície dentinária seca com ar foi a condição de pré-tratamento que mais restringiu a filtração após a aplicação do Gel Fluoretado.

Ao se interpretarem os dados da Tabela 11 no sentido vertical, ou seja, comparando os agentes anti-hiperestésicos entre si, para cada condição de pré-tratamento da dentina, pôde-se constatar que os géis de oxalato de potássio apresentaram valores de filtração estatisticamente semelhantes entre si, nas condições da dentina seca com ar, seca com papel e molhada. Nas condições da dentina acidificada e seca com ar ou seca com papel absorvente, o Oxa-Gel apresentou desempenho estatisticamente inferior aos demais géis de oxalato de potássio. Por outro lado, o Gel Fluoretado comportou-se sempre menos 
efetivamente no bloqueio da filtração da dentina quando comparado com os demais agentes anti-hiperestésicos, em todas as condições de pré-tratamento. Essas diferenças foram estatisticamente significantes.

No Gráfico 5 estão representadas as médias percentuais de filtração sob as diferentes condições de pré-tratamento da dentina, em relação aos agentes antihiperestésicos. Mostra claramente a pouca resistência à filtração apresentada pelo Gel Fluoretado em relação aos agentes à base de oxalato de potássio, para todas as condições de pré-tratamento da dentina.

Tabela 11 - Comparação intergrupos da condutividade hidráulica da dentina, em percentagem, após diferentes pré-tratamentos de superfície (Duncan, $\mathrm{p}<0,05$ ).

\begin{tabular}{|c|c|c|c|c|c|}
\hline & $\begin{array}{l}\text { Seca } \\
\text { com ar }\end{array}$ & $\begin{array}{c}\text { Seca } \\
\text { com papel }\end{array}$ & Molhada & $\begin{array}{l}\text { Acidificada e } \\
\text { seca com ar }\end{array}$ & $\begin{array}{c}\text { Acidificada e } \\
\text { seca com papel }\end{array}$ \\
\hline & Média $\pm S D$ & Média $\pm S D$ & Média $\pm S D$ & Média $\pm S D$ & Média $\pm S D$ \\
\hline Oxa-Gel & $10,593 \pm 6,738^{a}$ & $\left|14,476 \pm 7,966^{a}\right|$ & $\left|10,512 \pm 5,013^{a}\right|$ & $38,512 \pm 10,451^{b}$ & ${ }^{b} 33,502 \pm 20,923$ \\
\hline Experimental 1 & $14,538 \pm 11,402^{a}$ & $18,714 \pm 9,958^{a}$ & $16,322 \pm 7,412^{a}$ & $26,126 \pm 8,140^{9}$ & $14,561 \pm 7,143^{a}$ \\
\hline Experimental 2 & $212,355 \pm \frac{12,222^{a}}{b}$ & $15,399 \pm 8,811^{a b}$ & $4,331 \pm 3,244^{a}$ & $16,379 \pm 8,476^{b}$ & $10,158 \pm 9,543^{a b}$ \\
\hline Gel Fluoretado & $41,472 \pm 14,438^{a}$ & $62,890 \pm 14,599^{b}$ & $73,242 \pm 16,406^{c}$ & $77,474 \pm 8,227^{c}$ & $72,272 \pm 14,210^{b}$ \\
\hline
\end{tabular}


Gráfico 5 - Médias percentuais de filtração proporcionadas pelos agentes anti-hiperestésicos nos diferentes pré-tratamentos da superfície de dentina (Duncan, $p<0,05$ ).

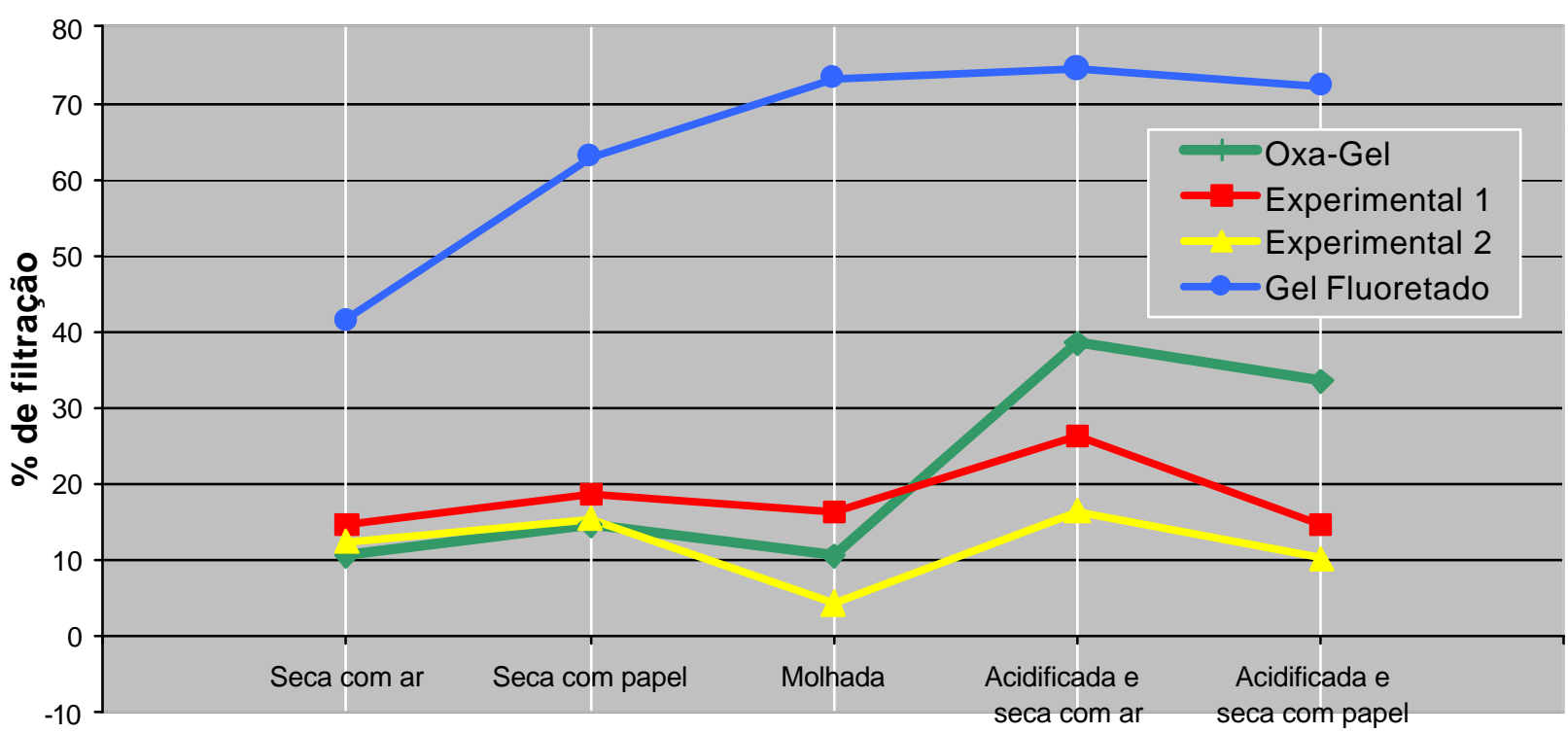

\section{Pré-tratamento da dentina}

O Gráfico 6 traduz geometricamente os dados apresentados na Tabela 11 e expõe, mais uma vez, a pequena variabilidade do gel Experimental 2 nos diferentes pré-tratamentos da dentina. Mostra, ainda, a tendência de ascensão da curva de filtração, provocada pelo Gel Fluoretado.

Gráfico 6 - Médias percentuais de filtração dos agentes anti-hiperestésicos em relação aos prétratamentos superficiais da dentina (Duncan, $p<0,05$ ).

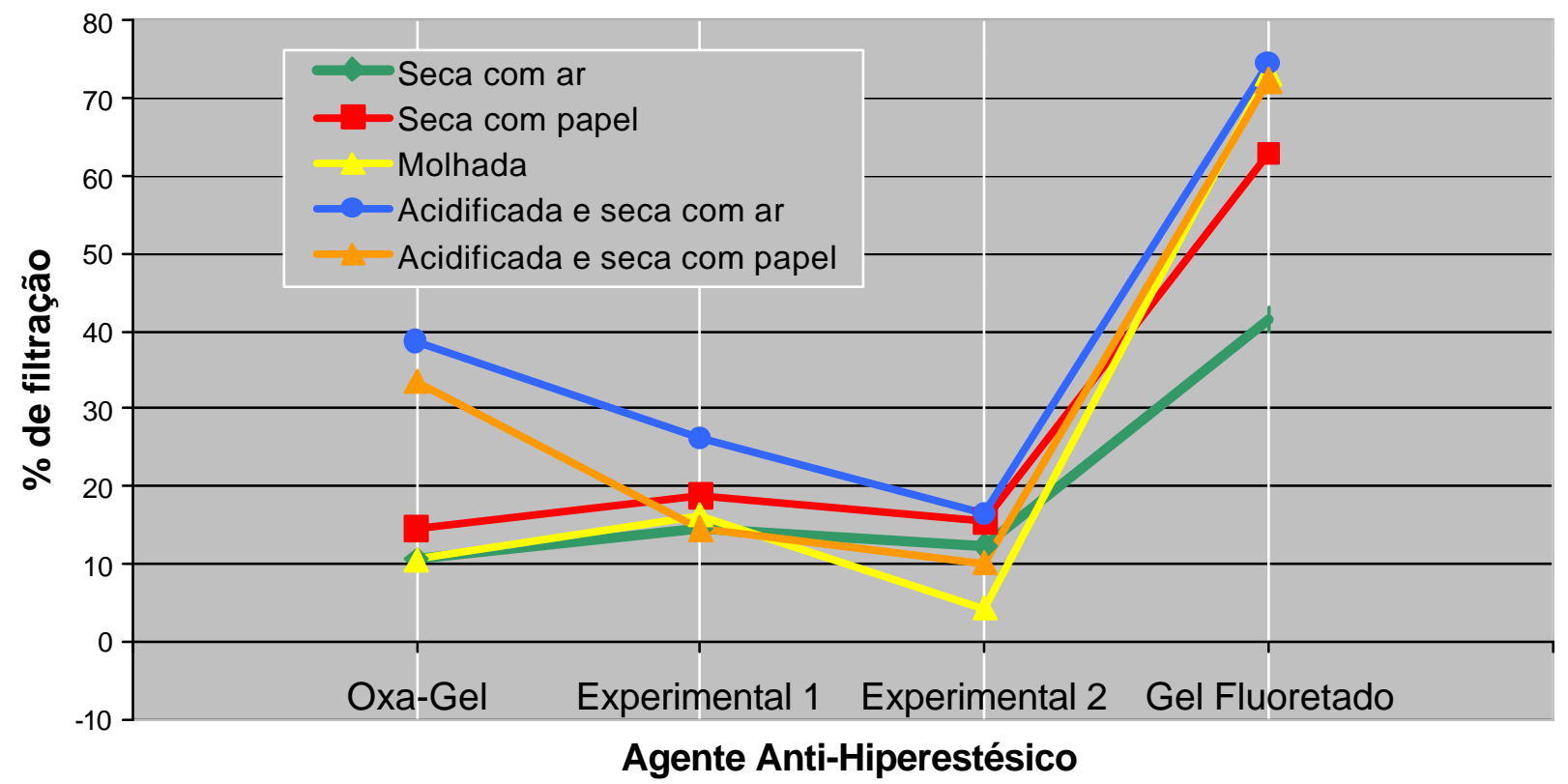




\subsection{Microscopia Eletrônica de Varredura}

Para a análise estatística dos ensaios de microscopia eletrônica de varredura utilizou-se da análise de variância a um e a dois critérios, aplicada aos valores percentuais, com nível de significância de 5\%, identificando as diferenças intragrupos e intergrupos, sendo as diferenças individuais estatisticamente significantes rastreadas pelo teste Múltiplo de Duncan, também com nível de significância de 5\%. Essa análise não detectou diferenças significantes entre as magens de microscopia eletrônica de varredura, nos efeitos dos materiais anti-hiperestésicos na obstrução da embocadura dos túbulos dentinários, mas encontrou significância estatística entre as etapas da seqüência experimental, quando analisadas intragrupos.

O comportamento dos agentes anti-hiperestésicos aplicados na superfície da dentina seca com ar está representado na Tabela 12 pelas médias percentuais e os respectivos desvios-padrão das áreas não obstruídas dos túbulos dentinários, acompanhados das significâncias estatísticas, e dispostos conforme a seqüência de experimentos executada. Os cálculos percentuais fornecidos pela análise digitalizada das imagens de microscopia eletrônica de varredura foram expressos em termos de percentagem da máxima desobstrução (100\%), obtida após a aplicação do EDTA.

Tabela 12 - Comparações intragrupos das áreas não obstruídas/desobstruídas dos túbulos dentinários, expressas em percentagem (média e desvio-padrão - Duncan, $p<0,05$ ).

\begin{tabular}{|c|c|c|c|c|}
\hline & Oxa-Gel & Experimental 1 & Experimental 2 & Gel Fluoretado \\
\hline EDTA & $100,000 \pm 00,000^{a}$ & $100,000 \pm 00,000^{a}$ & $100,000 \pm 00,000^{a}$ & $100,000 \pm 00,000^{a}$ \\
\hline Smear Layer & $08,789 \pm 11,758^{b}$ & $03,203 \pm 03,189^{b}$ & $02,179 \pm 00,687^{b}$ & $02,373 \pm 01,943^{b}$ \\
\hline Material & $15,647 \pm 10,719^{b c}$ & $14,030 \pm 09,856^{c}$ & $19,347 \pm 07,814^{c}$ & $20,195 \pm 06,504^{c}$ \\
\hline Desafio Ácido & $20,824 \pm 5,666^{c}$ & $21,704 \pm 07,746^{c}$ & $25,382 \pm 13,822^{c}$ & $42,017 \pm 20,199$ \\
\hline
\end{tabular}

Verticalmente, letras iguais representam diferenças não significantes 
Considerando os valores percentuais médios das áreas não obstruídas/desobstruídas em relação à área total das imagens, o Oxa-Gel foi o material com maior poder oclusivo (15,6\%), e estatisticamente semelhante à obstrução proporcionada pela smear layer $(8,7 \%)$. Os demais materiais mostraram sempre áreas não obstruídas estatisticamente maiores que as de suas respectivas smear layers. Após o desafio com ácido cítrico, a maior proporção de área desobstruída pertenceu ao Gel Fluoretado (42,0\%), e a menor ao Oxa-Gel (20,8\%). Do ponto de vista estatístico, todos os materiais tiveram desempenho semelhante quando se comparam as proporções de áreas não obstruídas de depois do tratamento e desobstruídas após desafio ácido, exceto para o Gel Fluoretado.

O Gráfico 7 representa os valores percentuais médios das áreas não obstruídas/desobstruídas após a aplicação dos agentes anti-hiperestésicos, dispostos na Tabela 12. Pode-se perceber que há uma considerável diferença após o desafio com ácido cítrico, especialmente no grupo do Gel Fluoretado. Em termos gerais, pode-se dizer que os materiais estudados proporcionaram áreas não obstruídas variando entre $15 \%$ e $20 \%$ da área desobstruída total (100\%), com ligeiro aumento após o desafio ácido nos espécimes tratados com os géis de oxalato de potássio (20\% a $25 \%$ ), e um aumento mais sensível com o Gel Fluoretado (42\%). 
Gráfico 7 - Representação gráfica das médias percentuais de áreas não obstruídas/desobstruídas após a execução da seqüência experimental, para cada material anti-hiperestésico (Duncan, < 0,05).

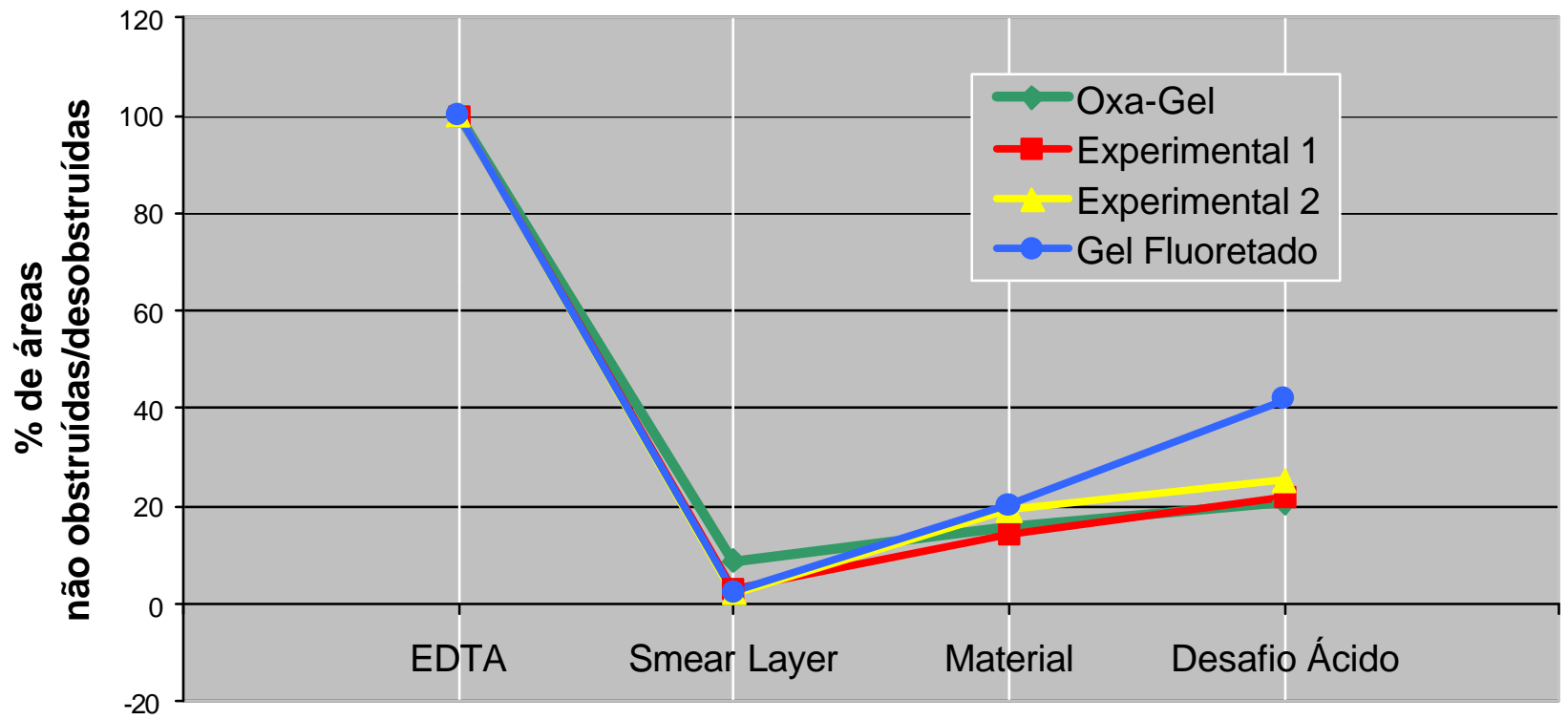

\section{Sequência Experimental}

A Tabela 13 ilustra a diferença entre os valores médios de áreas não obstruídas dos túbulos dentinários obtidos na presença da smear layer e após o tratamento com os materiais, e entre este e as áreas desobstruídas pelo desafio com ácido cítrico. A análise das diferenças permite a visão comparativa mais clara de desempenho dos diferentes materiais estudados, seguindo a seqüência dos experimentos, independentemente de suas significâncias estatísticas.

Tabela 13 - Diferença entre os valores médios de áreas não obstruídas/desobstruídas dos túbulos dentinários, em percentagem, nas diferentes etapas do experimento (Duncan, $p<0,05)$.

\begin{tabular}{r|ccccc} 
& \multicolumn{3}{c}{ Smear Layer } & Material & Desafio \\
\cline { 2 - 5 } Oxa-Gel & 8,789 & & 15,647 & & 20,824 \\
Diferença & & $-6,858$ & & $-5,177$ & \\
\cline { 3 - 6 } Experimental 1 & 3,203 & & 14,030 & & 21,704 \\
Diferença & & $-10,827$ & & $-7,674$ & \\
\cline { 5 - 6 } Experimental 2 & 2,179 & & 19,347 & & 25,382 \\
Diferença & & $-17,168$ & & $-6,035$ & \\
\cline { 5 - 6 } Gel Fluoretado & 2,373 & & 20,195 & & 42,017 \\
Diferença & & $-17,822$ & & $-21,822$ & \\
\end{tabular}


Para maior visualização do desempenho dos materiais em função da seqüência experimental, os valores proporcionais de áreas não obstruídas/desobstruídas, dispostos na Tabela 13, foram projetados no Gráfico 8, sem o percentual referente ao EDTA. Observa-se que houve, invariavelmente para todos os materiais, a ampliação das áreas não obstruídas/desobstruídas no decorrer do experimento, sendo na presença da smear layer a menor área de dentina não obstruída, seguida pelo tratamento com o material e, por último, após o desafio ácido. As Figuras de 34 a 37 ilustram a seqüência experimental, caracterizando a evolução da não obstrução/desobstrução dos túbulos dentinários. Essas figuras mostram também o padrão de obstrução intratubular dos espécimes tratados e desafiados com ácido.

Gráfico 8 - Representação gráfica das médias percentuais das áreas não obstruídas/desobstruídas na presença da smear layer, após a aplicação do material anti-hiperestésico e após o desafio com ácido cítrico (Duncan, $p<0,05$ ).

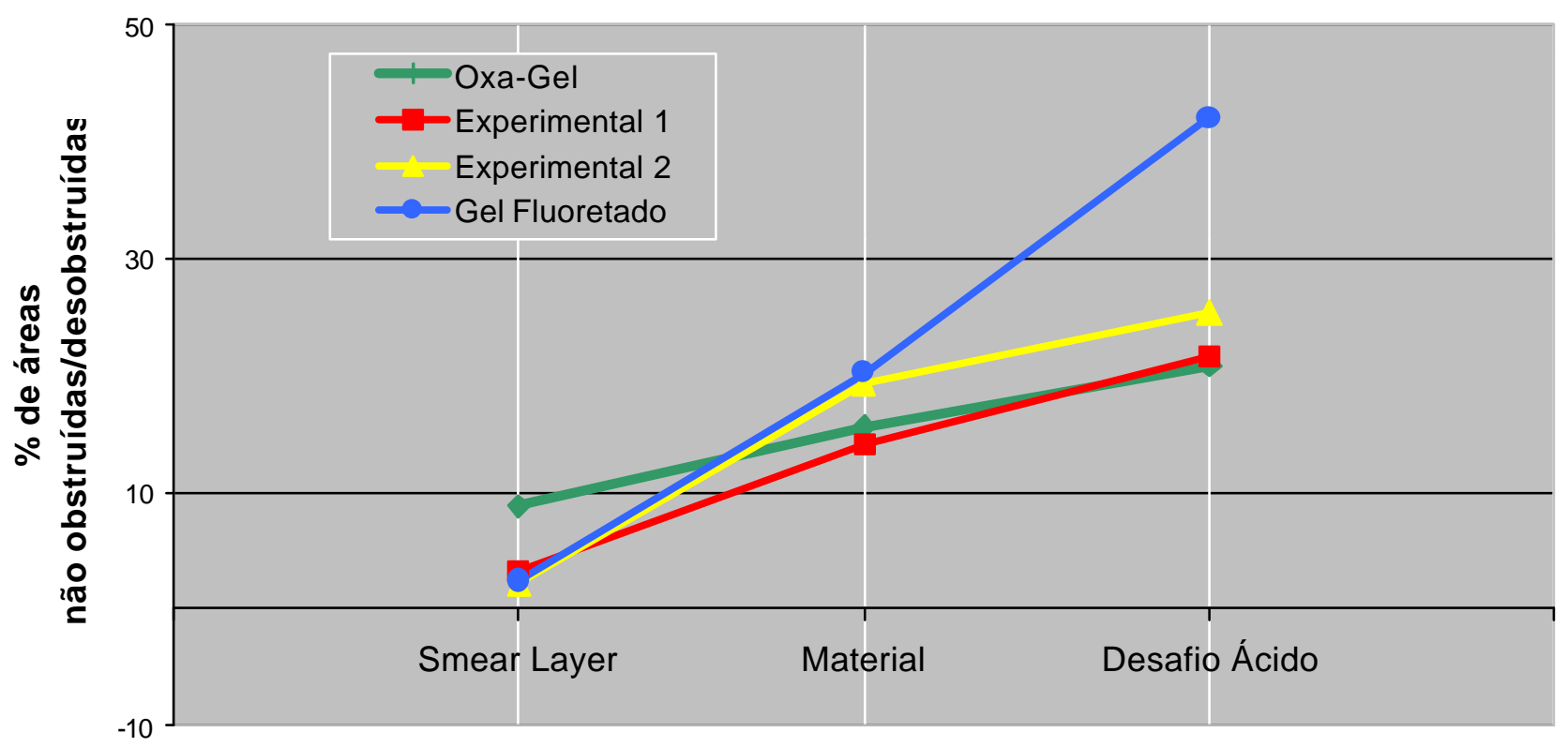

Seqüência Experimental

No Gráfico 9 percebe-se claramente a diferença no comportamento dos materiais anti-hiperestésicos com relação à seqüência experimental, quando a condição EDTA conferiu o valor máximo de desobstrução (100\%), e a smear layer o valor mínimo de áreas não obstruídas. Os materiais exerceram um efeito obstrutivo nos túbulos, alcançando 
valores mais próximos aos da smear layer, sendo que o desafio ácido, representando a resistência dos materiais estudados ao ambiente ácido, provocou um aumento da área não obstruída dos canalículos para todos os materiais, especialmente para o Gel Fluoretado.

Gráfico 9 - Representação gráfica das médias percentuais de áreas não obstruídas/desobstruídas após a aplicação dos materiais experimentais, em relação à seqüência experimental (Duncan, $p<0,05$ ).

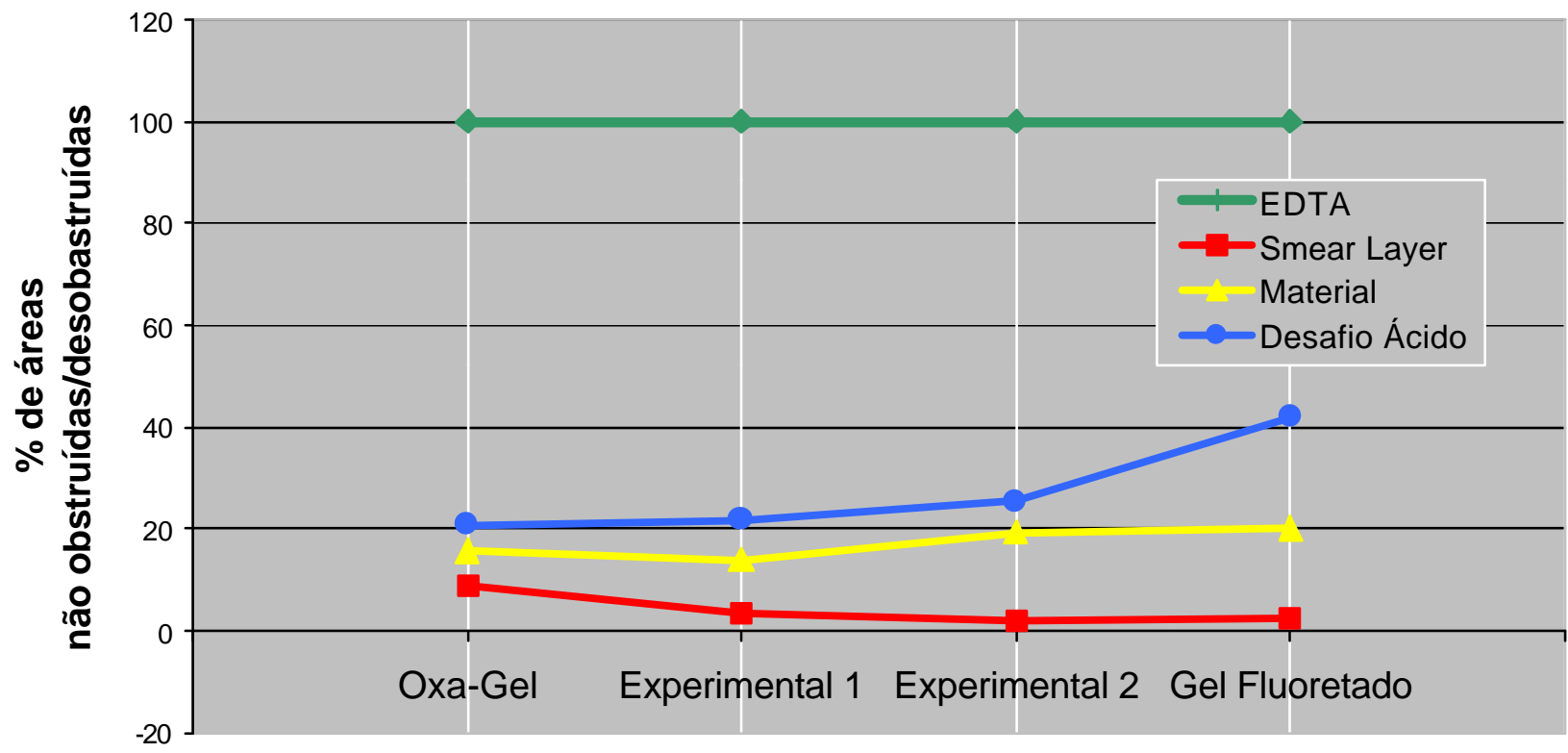

Seqüência Experimental

A Tabela 14A representa os valores percentuais médios de obstrução após o tratamento com os agentes anti-hiperestésicos, independentemente da seqüência experimental. Diferença estatisticamente significante foi detectada entre os valores dos Gel Fluoretado e do Experimental 1, enquanto entre este, o Oxa-Gel e o Experimental 2, os valores numéricos foram bastante semelhantes entre si e confirmados estatisticamente. 0 efeito das etapas experimentais na obstrução dos túbulos dentinários, analisado independentemente do material empregado, mostrou-se estatisticamente significante, como apresentado na Tabela 14B. Comparativamente ao condicionamento com EDTA, a simulação da smear layer proporcionou uma área não obstruída proporcional de 4,1\%. Ainda, comparativamente ao EDTA, a aplicação dos materiais anti-hiperestésicos reduziu a área de não obstrução para 17,3\%, aumentando para 27,3\% após o desafio ácido. 
Tabela 14 - A- Efeito dos agentes anti-hiperestésicos na obstrução dos túbulos dentinários, independentemente das condições analisadas, em percentagem de área não obstruída (Duncan, $\mathrm{p}<0,05$ ).

B - Percentagem de área não obstruída/desobstruída dos túbulos dentinários na seqüência experimental, independentemente do agente anti-hiperestésico (Duncan, $p<0,05)$.

\begin{tabular}{|c|c|c|c|}
\hline \multicolumn{2}{|c|}{ A - Efeito principal - MATERIAL } & \multicolumn{2}{|c|}{ B - Efeito principal - CONDIÇÃO } \\
\hline & Média \pm SD & & Média $\pm S D$ \\
\hline Oxa-Gel & $36,315 \pm 38,759^{a b}$ & EDTA & $100,000 \pm 00,000^{a}$ \\
\hline Experimental 1 & $34,734 \pm 39,689^{a}$ & Smear Layer & $04,136 \pm 06,316^{b}$ \\
\hline Experimental 2 & $36,727 \pm 39,168^{a b}$ & Material & $17,304 \pm 08,558^{c}$ \\
\hline Gel Fluoretado & $41,146 \pm 38,967^{b}$ & Desafio Ácido & $27,482 \pm 14,923$ \\
\hline
\end{tabular}

Verticalmente, letras iguais representam diferenças não significantes

A análise das superfícies fraturadas permitiu registrar a profundidade de precipitação de cristais no interior dos túbulos dentinários. Na Tabela 15 observa-se que os cristais foram registrados a uma profundidade média no interior dos túbulos de $9,41 \mu \mathrm{m}, 8,40 \mu \mathrm{m}$ e 7,52 $\mu \mathrm{m}$, respectivamente para o Oxa-Gel, Experimental 1 e Experimental 2. Nos espécimes tratados com o Gel Fluoretado foram detectadas raríssimas deposições de cristais no interior dos túbulos, a uma profundidade média de 12,32 $\mu \mathrm{m}$.

Tabela 15 - Profundidade de precipitação dos cristais mínima, máxima e média após o tratamento da dentina com os diferentes agentes anti-hiperestésicos.

\begin{tabular}{l|ccc}
\multicolumn{1}{c}{} & \multicolumn{3}{c}{ Profundidade dos cristais $(\boldsymbol{\mu m})$} \\
\cline { 2 - 4 } & Mínima & Máxima & Média \\
\cline { 2 - 4 } Oxa-Gel & 2,23 & 16,67 & 9,41 \\
\cline { 2 - 4 } Experimental 1 & 3,98 & 12,33 & 8,40 \\
Experimental 2 & 3,18 & 14,64 & 7,52 \\
\hline Gel Fluoretado & 6,02 & 16,13 & 12,32 \\
\hline
\end{tabular}


Também foram confrontados os resultados dos estudos de condutividade hidráulica e de microscopia eletrônica de varredura. Essa comparação restringiu-se aos valores percentuais médios obtidos após o emprego dos agentes anti-hiperestésicos na dentina seca com ar, representada pela Tabela 16 e ilustrada pelo Gráfico 10.

Os valores percentuais médios de filtração proporcionados pelos agentes antihiperestésicos variaram de $10,5 \%$ a $41,4 \%$, enquanto que para a análise em microscopia eletrônica de varredura as médias percentuais das áreas não obstruídas variaram entre $14,0 \%$ e $20,1 \%$. Como se pode ver, o valor de filtração foi estatisticamente maior no grupo do Gel Fluoretado do que nos demais grupos. Na análise ao microscópio eletrônico de varredura, entretanto, os valores de não obstrução foram considerados estatisticamente semelhantes entre todos os materiais. Pode-se perceber, também, que os materiais à base de oxalato de potássio estão localizados em uma faixa estreita de valores percentuais, valores esses observados tanto em relação às áreas de obstrução canalicular como à filtração.

Tabela 16 - Comparação entre os dados obtidos através dos experimentos de condutividade hidráulica e das imagens de microscopia eletrônica de varredura para os quatro materiais anti-hiperestésicos, sob a condição de pré-tratamento da dentina seca com ar.

\begin{tabular}{l|c|c|}
\multicolumn{1}{c}{} & \multicolumn{1}{c}{ Condutividade } & Microscopia \\
\cline { 2 - 3 } & Média \pm SD & Média \pm SD \\
\hline Oxa-Gel & $10,593 \pm 06,738$ & $15,647 \pm 10,719$ \\
Experimental 1 & $14,538 \pm 11,402$ & $14,030 \pm 09,856$ \\
\hline Experimental 2 & $12,355 \pm 12,222$ & $19,347 \pm 07,814$ \\
Gel Fluoretado & $41,472 \pm 14,438$ & $20,195 \pm 06,504$
\end{tabular}

Barras unem diferenças não significantes 
Gráfico 10 - Comparação entre as médias percentuais obtidas após a aplicação dos materiais antihiperestésicos na dentina seca com ar, analisadas por meio de ensaios em microscopia eletrônica de varredura e de condutividade hidráulica.

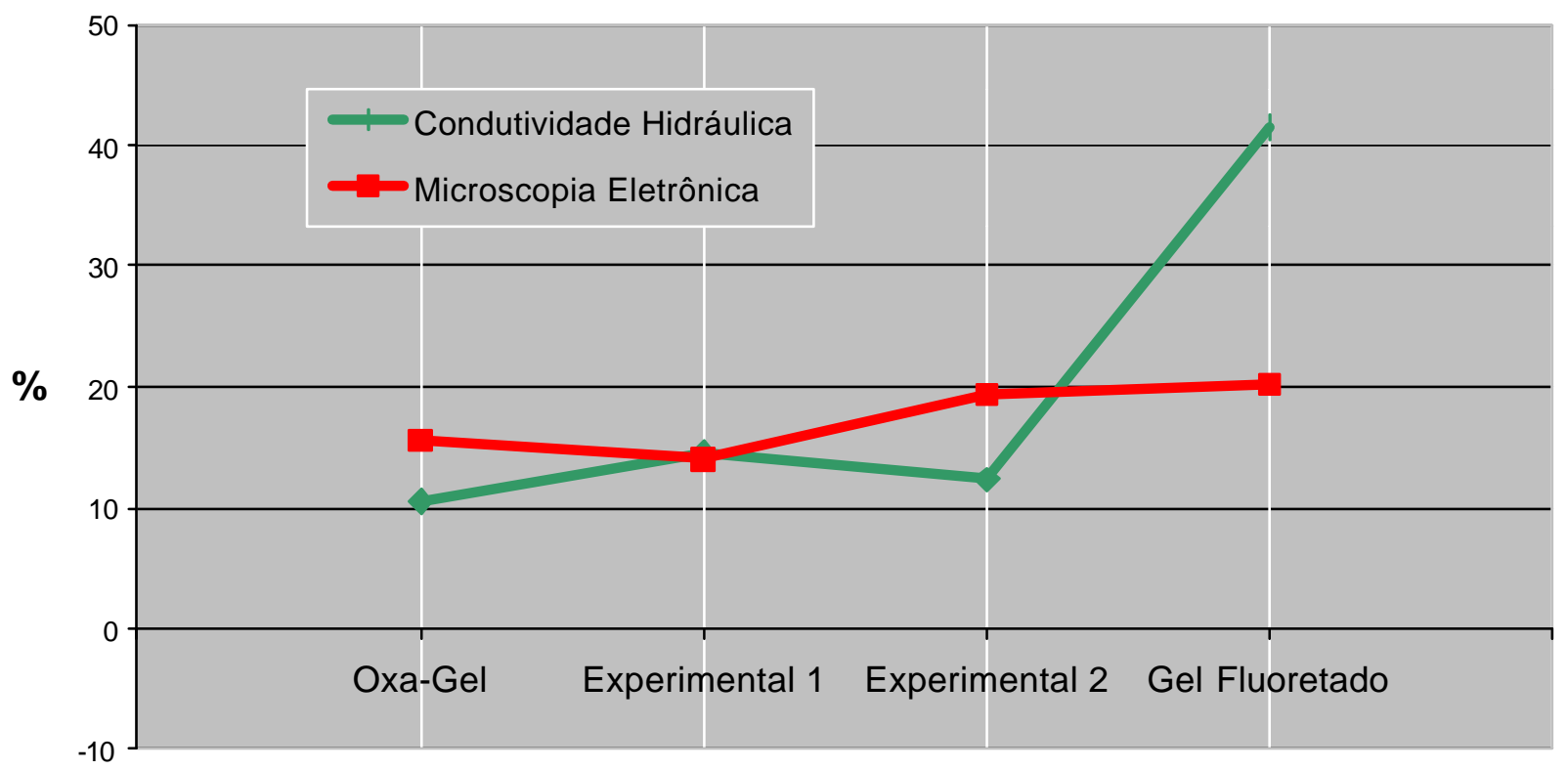

Agentes Anti-Hiperestésicos 

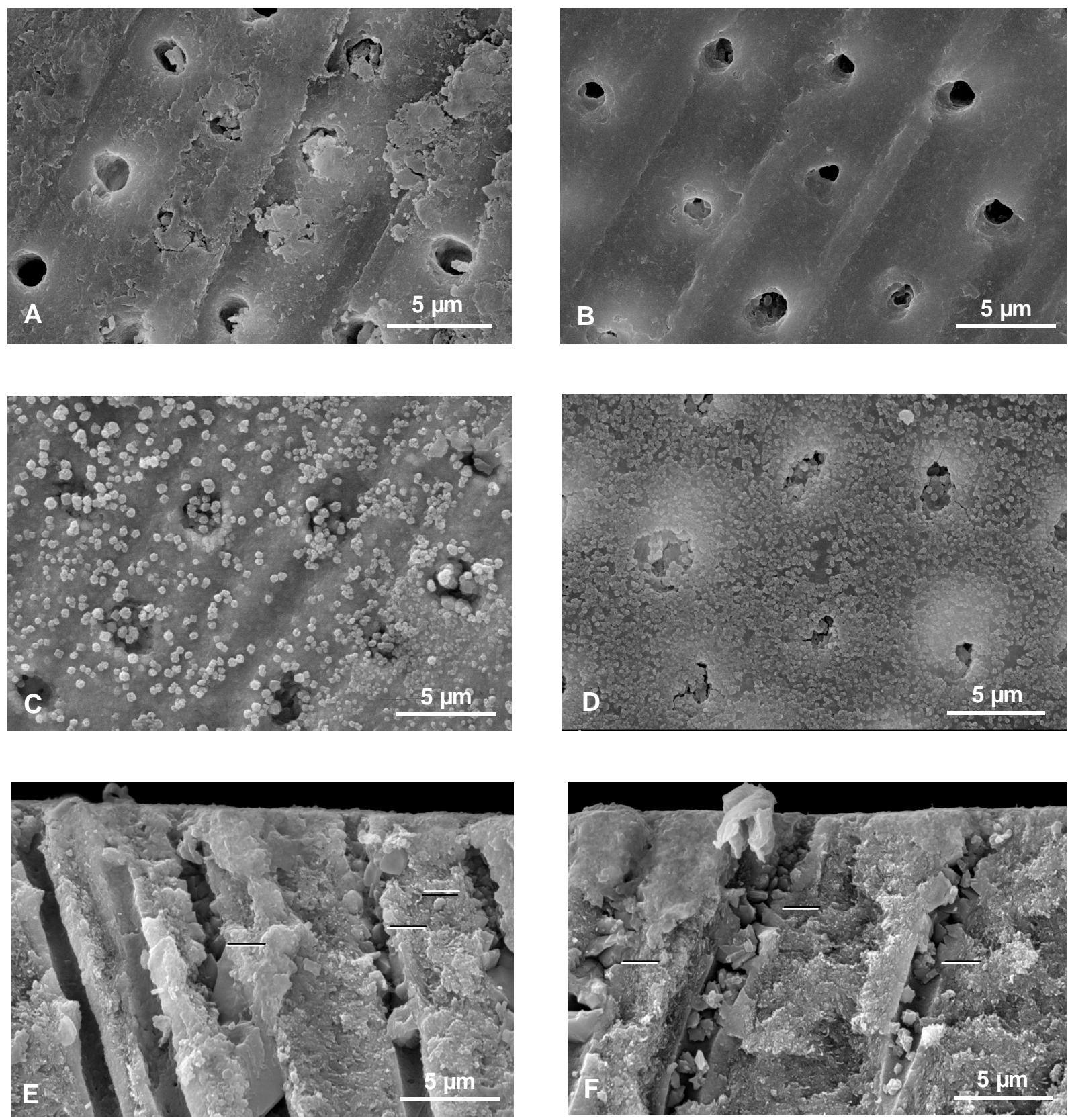

Figura 34 - Imagens microscópicas da seqüência experimental executada com o material OxaGel: A - imagem da smear layer simulada com lixas; B - aparência da dentina limpa com EDTA; C - aspecto da dentina tratada com Oxa-Gel. Observam-se cristais obstruindo as embocaduras dos túbulos dentinários; D - após o desafio com ácido cítrico a $6 \%$, percebe-se a remoção parcial dos cristais da superfície, permanecendo aqueles localizados nas embocaduras tubulares; $\mathbf{E}$ - imagem dos cristais de oxalato de cálcio acomodados no interior dos túbulos dentinários após a ação do OxaGel na superfície da dentina; $\mathbf{F}$ - não se observam, nesse espécime, modificações no padrão de obstrução intra-tubular após o desafio ácido. 

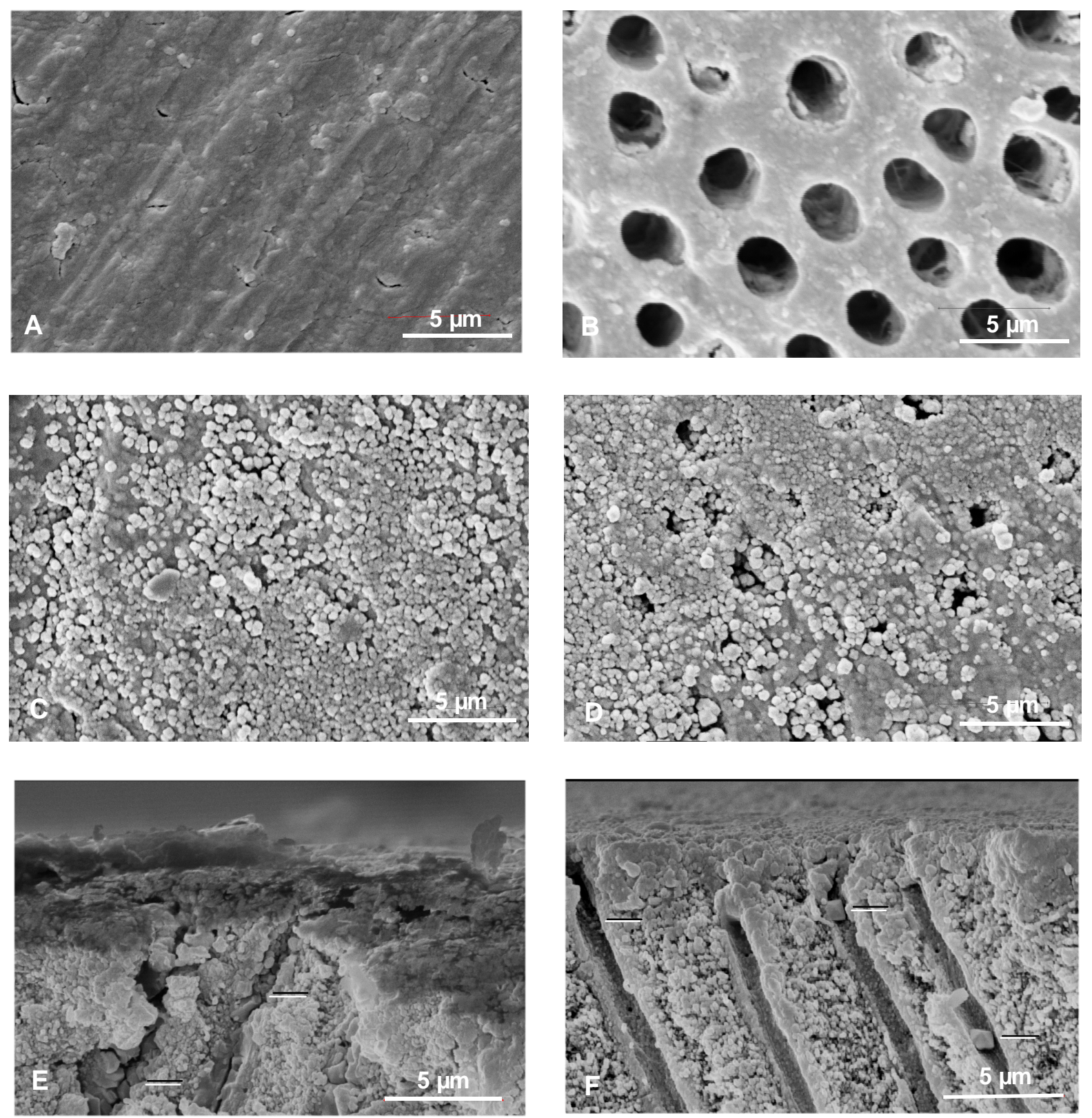

Figura 35 - Imagens microscópicas da seqüência experimental executada com o material Experimental 1: A - smear layer simulada in vitro; $\mathbf{B}$ - remoção da smear layer após o condicionamento com EDTA; C - aspecto da superfície da dentina tratada com o agente Experimental 1, obstruindo completamente as aberturas tubulares; D - pequenas modificações foram notadas após o desafio com ácido das superfícies tratadas; E-cristais puderam ser vistos no interior dos túbulos tratados com o Experimental 1; F - o ácido cítrico não modificou o padrão obstrutivo dos túbulos tratados com esse material. 

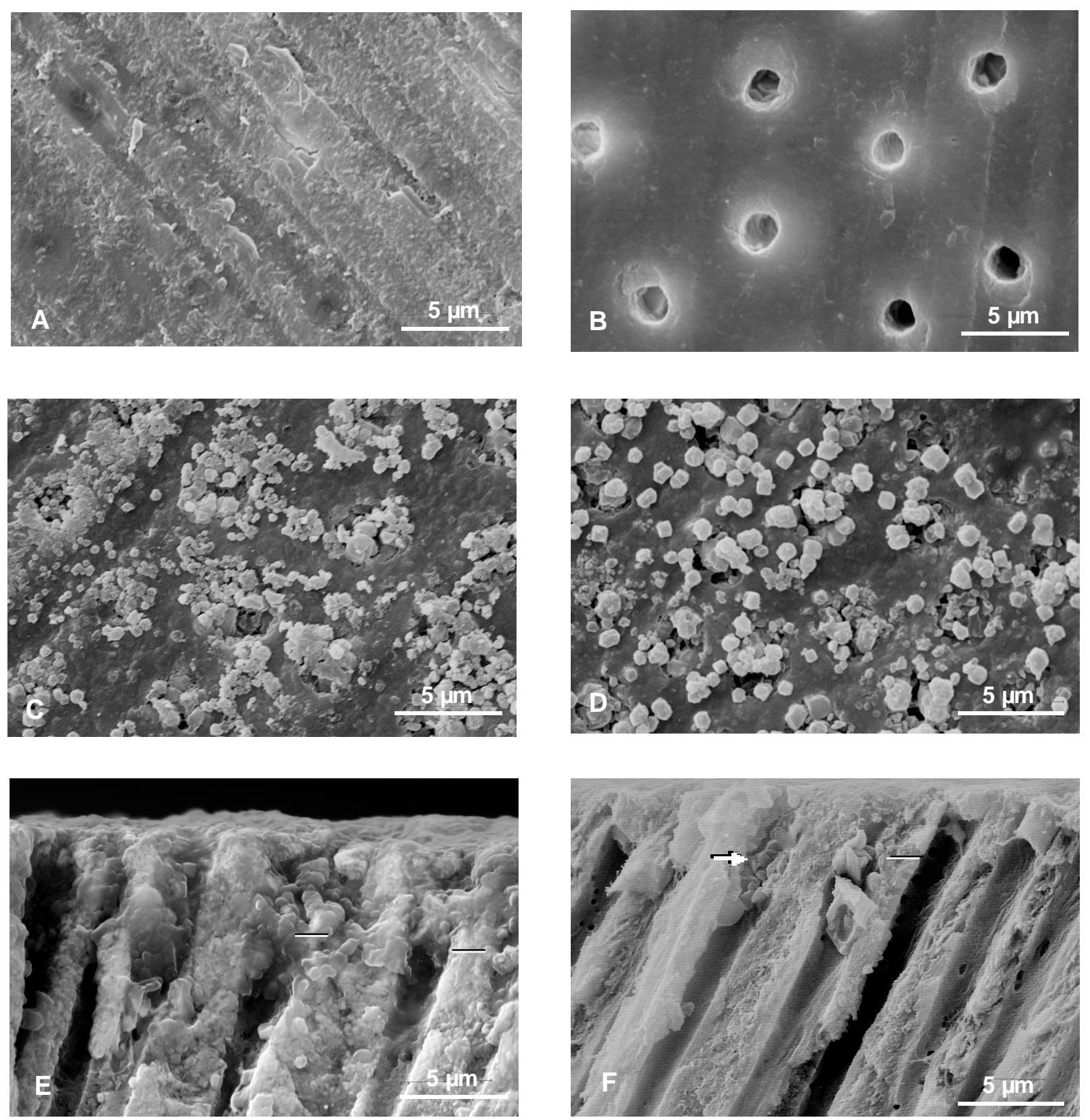

Figura 36 - Imagens microscópicas da seqüência experimental executada com o material Experimental 2: A - aspecto amorfo e homogêneo característico da smear layer; $\mathbf{B}$ remoção completa da smear layer após o condicionamento com EDTA; C - aspecto da superfície da dentina tratada com o agente Experimental 2, obstruindo as aberturas tubulares com formações cristalinas de diferentes tamanhos; D - após o desafio ácido, percebe-se que a maior parte das partículas menores foram removidas, e os cristais maiores permaneceram obstruindo as aberturas tubulares; $\mathbf{E}$ - presença de cristais no interior dos túbulos aglomerados com remanescentes do material; F - após a ação do ácido cítrico, os cristais ainda puderam ser observados intratubularmente. 

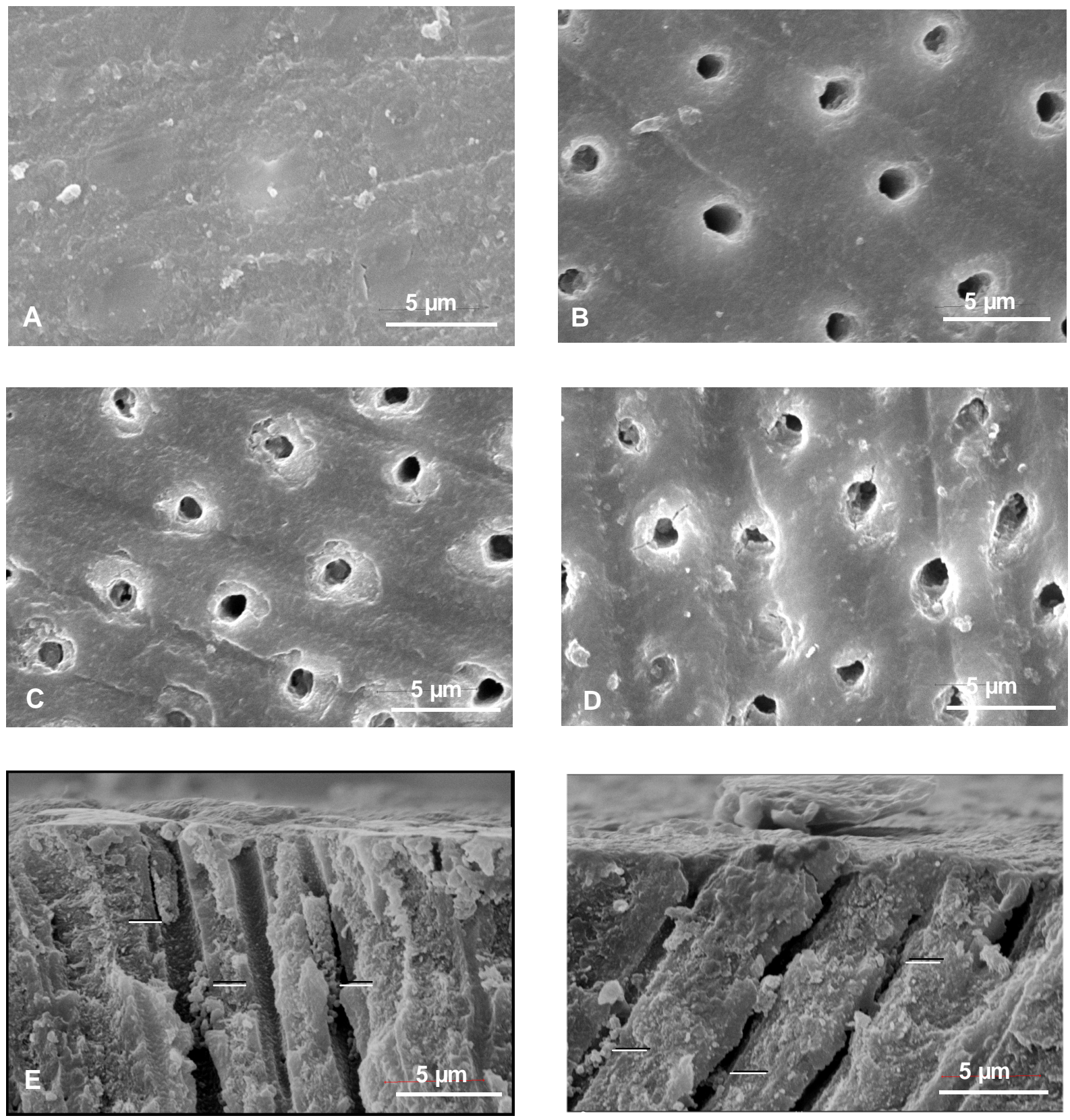

Figura 37 - Imagens microscópicas da seqüência experimental executada com o material Gel Fluoretado: A - dentina coberta pela smear layer; B - limpeza da superfície após o condicionamento com EDTA; $\mathbf{C}$ - aspecto da superfície da dentina tratada com o Gel Fluoretado, mostrando a ausência de cristais e o pequeno poder obstrutivo do material; D - o desafio ácido não modificou o padrão da superfície em relação ao da dentina tratada, observando-se apenas a superfície livre dos remanescentes do material; E - os pequenos cristais de fluoreto de cálcio puderam ser vistos no interior dos túbulos tratados com o Gel Fluoretado, formando uma espécie de tampão; F esse material não mostrou boa resistência ao desafio com ácido cítrico, apesar de ainda serem vistos cristais no interior dos túbulos.

\subsection{Microanálise de Raios X (EDS)}


A microanálise qualitativa dos elementos químicos que compõem os espécimes dentinários tratados com os agentes anti-hiperestésicos produziu espectros muito semelhantes entre si, sendo que os picos de cálcio e fósforo se destacaram dentre os demais elementos da análise, seguido pelo oxigênio, como mostra o Gráfico 11.

Gráfico 11 - Espectro de raios X mostrando picos característicos dos elementos em níveis específicos de energia.

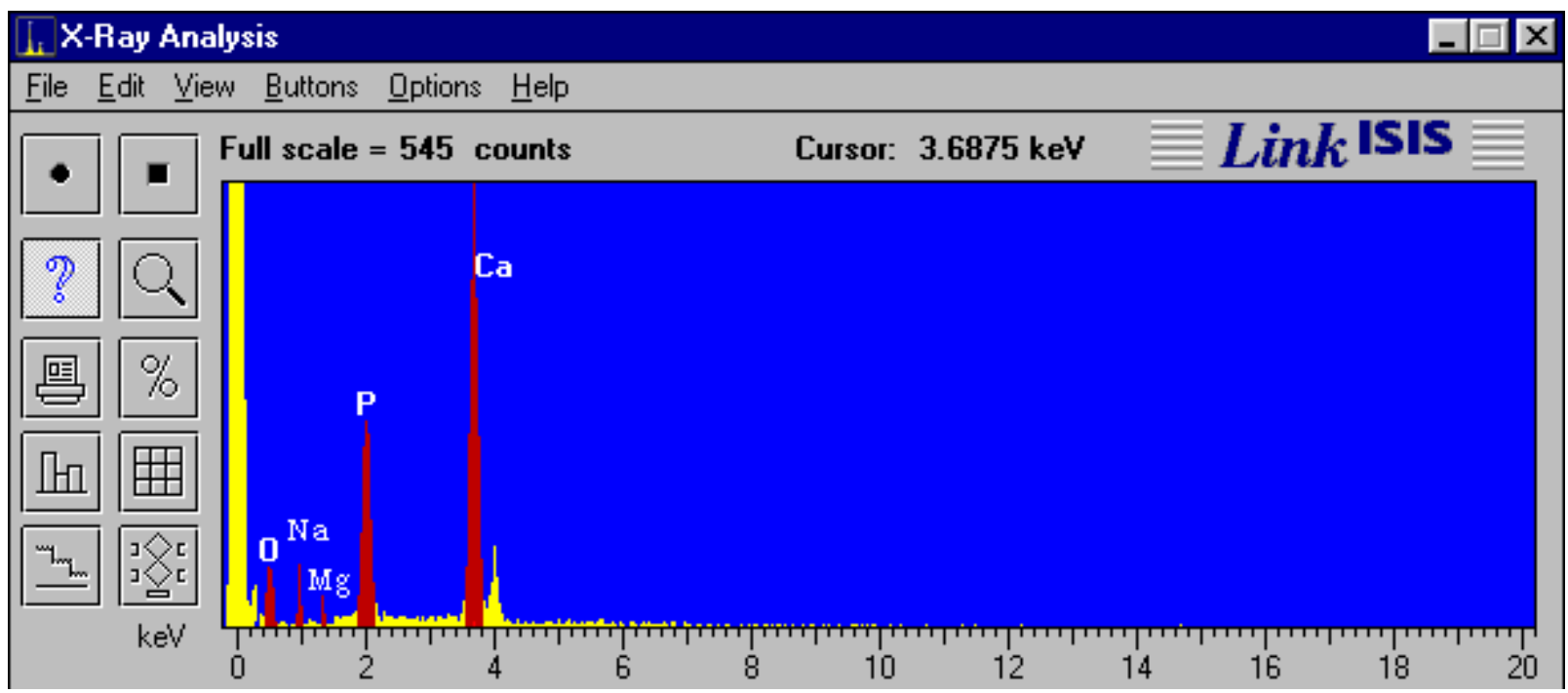

As percentagens dos elementos foram também fornecidas pela microanálise, mostrando valores variáveis para os principais componentes das amostras nos diferentes grupos. O cálcio foi o elemento que apareceu em maior percentagem, seguido pelo fósforo e pelo oxigênio. Pequenas percentagens de sódio e magnésio também foram observadas, como mostra a Tabela 17.

Tabela 17 - Percentagem dos elementos químicos encontrados após o tratamento da dentina com os agentes anti-hiperestésicos, através da microanálise semiquantitativa de raios $\mathrm{X}$.

\begin{tabular}{l|cccc}
\multirow{2}{*}{ Cálcio } & Oxa-Gel & Experimental 1 & Experimental 2 & Gel Fluoretado \\
\cline { 2 - 5 } Fósforo & 64,42 & 64,55 & 65,13 & 67,89 \\
\hline Oxigênio & 21,24 & 20,41 & 19,83 & 21,73 \\
\cline { 2 - 5 } Sódio & 8,06 & 8,43 & 8,13 & 4,47 \\
Magnésio & 1,05 & 1,42 & 2,28 & 1,77 \\
\cline { 2 - 5 } & 1,30 & 1,34 & 0,85 & 0,77
\end{tabular}

Observa-se por essa tabela que a variação na percentagem de cálcio é aproximada para os géis de oxalato de potássio e sensivelmente mais elevada para o Gel Fluoretado. 
Essa variação já não é tão nítida quando se observa a quantidade de fósforo. Quanto ao oxigênio, a análise semiquantitativa mostra que os géis à base de oxalato de potássio mantêm uma concentração maior desse elemento comparado com o Gel Fluoretado.

\subsection{Difração de Raios $X$}

A análise qualitativa da dentina através de ensaios de difração de raios $\mathrm{X}$ apresenta os resultados por meio de espectros, fornecendo as fases cristalinas presentes nos espécimes analisados, como exemplificado pelo Gráfico 12.

Gráfico 12 - Exemplo de espectro obtido nos ensaios de difração de raios X, identificando as fases cristalinas presentes nos espécimes analisados

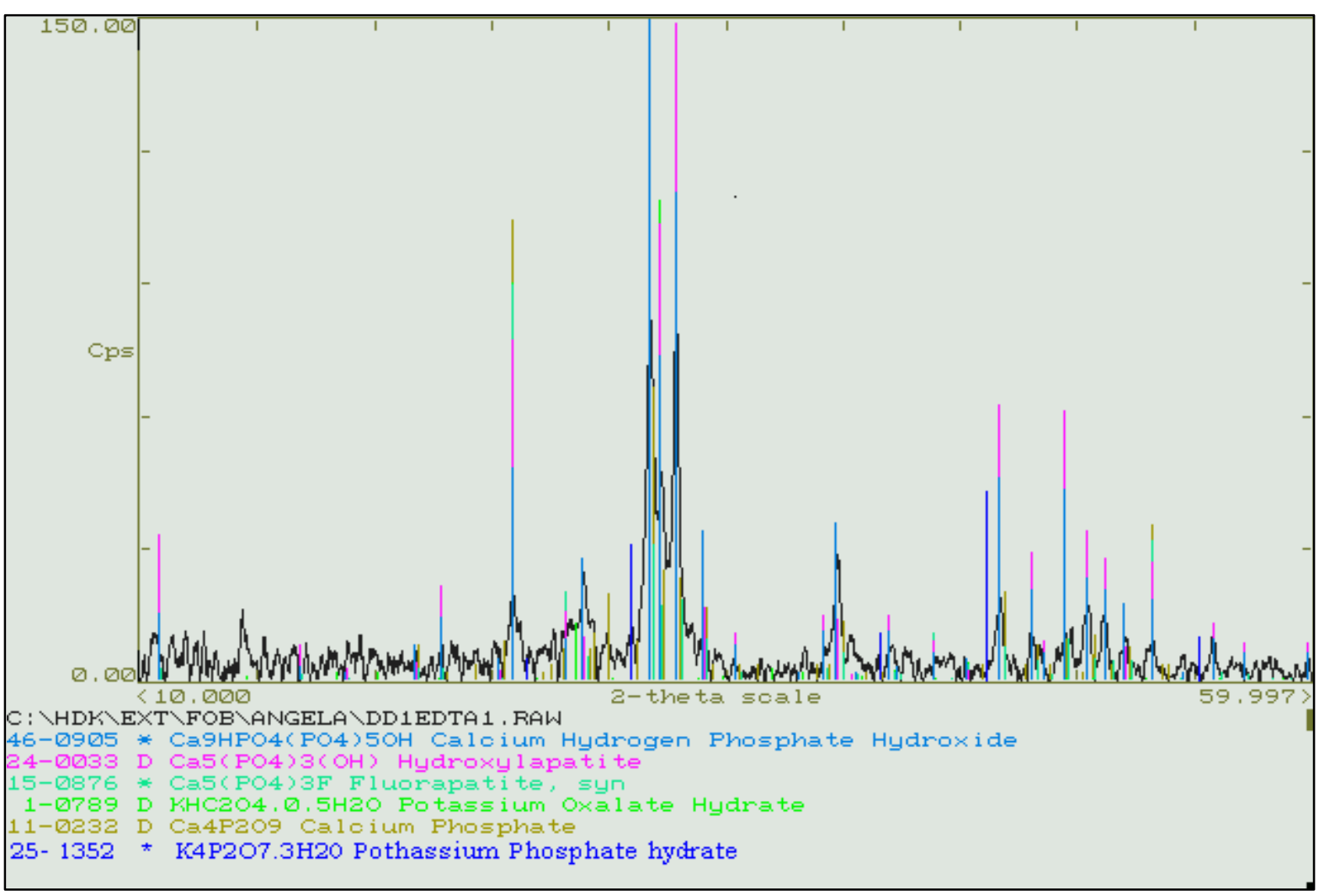

A análise de difração de raios $X$ aplicada sobre os discos de dentina, conforme relatado em material e métodos, mostra que alguns compostos 
encontrados após a aplicação dos materiais experimentais no substrato dentinário são comuns para todos os grupos, inclusive os correspondentes à dentina não tratada, condicionada ou não com EDTA. Esses compostos são a fluorapatita, a hidroxiapatita, a hidroxiapatita cálcio-deficiente e o pirofosfato de potássio trihidratado. A Tabela 18 mostra a ocorrência desses compostos nos espécimes estudados. É de maior interesse a observação daqueles compostos que sejam, em hipótese, decorrentes da reação dos géis experimentados com o substrato dentinário. Assim, a tabela mostra que a análise detectou a presença de fluoreto de cálcio nos espécimes tratados com Gel Fluoretado, seja nos espécimes submetidos ou não ao condicionamento prévio com EDTA, em ambos os períodos de tempo estudados (3 e 12 minutos).

Quanto aos espécimes tratados com os géis à base de oxalato de potássio, a expectativa de formação de oxalato de cálcio confirmou-se claramente no grupo do gel Experimental 2 e, parcialmente, no grupo do Oxa-Gel. Neste, não se observou a presença de oxalato de cálcio di-hidratado nos espécimes previamente condicionados com EDTA, nos quais o Oxa-Gel foi aplicado por três minutos. A presença de fosfato de cálcio potássio, também como provável produto da reação dos géis de oxalato de potássio com o substrato dentinário, é evidente nos espécimes tratados com esses géis, exceto naqueles com smear layer remanescente, tratados com Oxa-Gel por três minutos. É, ainda, de relevância destacar a permanência de resíduos de oxalato de potássio hidratado nos espécimes tratados com gel Experimental 1, nos quais foi observada também a presença de fosfato de cálcio. Diferentemente do Oxa-Gel e do gel Experimental 2, o oxalato de cálcio di-hidratado e o fosfato de cálcio potássio não foram detectados após a aplicação do gel Experimental 1.

Tabela 18 - Distribuição dos compostos químicos encontrados nos discos de dentina tratados com os agentes anti-hiperestésicos, conforme a condição da superfície e o tempo de aplicação, por meio de testes de difração de raios $X$ 


\begin{tabular}{|c|c|c|c|c|c|c|c|c|c|c|c|}
\hline \multicolumn{12}{|c|}{ Discos de Dentina } \\
\hline \multirow{2}{*}{$\begin{array}{l}\text { Material } \\
\text { Dentina }\end{array}$} & \multicolumn{2}{|c|}{ Condição Tempo } & \multicolumn{9}{|c|}{ Compostos encontrados } \\
\hline & Smear Layer & & - & $\mathrm{O}$ & 0 & $\bullet$ & & & & & - \\
\hline Dentina & EDTA & & - & 0 & - & ○ & & & & & - \\
\hline Flúor & Smear Layer & $3^{\prime}$ & - & 0 & - & 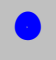 & & & & & ○ \\
\hline Flúor & Smear Layer & $12^{\prime}$ & ? & 0 & - & 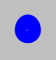 & & & & & $\bullet$ \\
\hline Flúor & EDTA & $3^{\prime}$ & - & 0 & - & - & & & & & - \\
\hline Flúor & EDTA & $12^{\prime}$ & ○ & 0 & ? & ○ & & & & & ○ \\
\hline Oxa-Gel & Smear Layer & $3^{\prime}$ & - & 0 & - & $\bullet$ & & 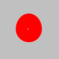 & & & \\
\hline Oxa-Gel & Smear Layer & $12^{\prime}$ & $\bullet$ & 0 & - & $\bullet$ & & - & - & & \\
\hline Oxa-Gel & EDTA & $3^{\prime}$ & - & 0 & - & - & & & - & & \\
\hline Oxa-Gel & EDTA & $12^{\prime}$ & - & 0 & - & - & & 0 & - & & \\
\hline Experimental 1 & Smear Layer & $3^{\prime}$ & 0 & $\mathrm{O}$ & 0 & 0 & ○ & & & 0 & \\
\hline Experimental 1 & Smear Layer & $12^{\prime}$ & - & 0 & - & - & ○ & & & 0 & \\
\hline Experimental 1 & EDTA & $3^{\prime}$ & - & 0 & - & 0 & $\odot$ & & & 0 & \\
\hline Experimental 1 & EDTA & $12^{\prime}$ & - & 0 & - & $\bullet$ & ○ & & & 0 & \\
\hline Experimental 2 & Smear Layer & $3^{\prime}$ & - & 0 & - & - & & - & $\bullet$ & & \\
\hline Experimental 2 & Smear Layer & $12^{\prime}$ & - & 0 & - & $\bullet$ & & $\bullet$ & - & & \\
\hline Experimental 2 & EDTA & $3^{\prime}$ & - & 0 & - & 0 & & - & - & & \\
\hline Experimental 2 & EDTA & $12^{\prime}$ & - & 0 & - & ○ & & $\bullet$ & - & & \\
\hline
\end{tabular}

Quando a mesma seqüência de experimentação e análise difratométrica foram realizadas sobre pó de dentina, não foram observadas ocorrências coerentes em relação à reatividade desses substratos com os géis experimentados (Tabela 19). Observou-se para as amostras de pó de dentina sem tratamento a presença de fases de hidroxiapatita, hidroxiapatita cálcio-deficiente e fluoreto de cálcio. Fluoreto de cálcio também foi encontrado 
no pó de dentina tratado com flúor por 3 e 12 minutos. Fluorapatita, pirofosfato de potássio tri-hidratado, hidroxiapatita e hidroxiapatita cálcio-deficiente foram eventos comuns a todos os espécimes. Todas as amostras tratadas com géis à base de oxalato de potássio apresentaram resíduos de oxalato de potássio hidratado.

Tabela 19 - Distribuição dos compostos químicos encontrados na dentina pulverizada tratada com os agentes anti-hiperestésicos, conforme o tempo de aplicação, através de testes de difração de raios $X$

\section{Pó de Dentina}

\begin{tabular}{|c|c|c|c|c|c|c|c|}
\hline Material & Tempo & \multicolumn{6}{|c|}{ Compostos encontrados } \\
\hline Dentina & & ? & O & - & & & \\
\hline Flúor & $3^{\prime}$ & - & O & - & $\bullet$ & & $\bullet$ \\
\hline Flúor & $12^{\prime}$ & - & O & - & - & & $\bullet$ \\
\hline Oxa-Gel & $3^{\prime}$ & ○ & O & - & - & $\mathrm{O}$ & \\
\hline Oxa-Gel & $12^{\prime}$ & - & O & - & - & O & \\
\hline Experimental 1 & $3^{\prime}$ & - & & - & - & 0 & \\
\hline Experimental 1 & $12^{\prime}$ & - & O & - & - & $\mathrm{O}$ & \\
\hline Experimental 2 & $3^{\prime}$ & - & 0 & - & - & $\mathrm{O}$ & \\
\hline Experimental 2 & $12^{\prime}$ & ? & $\mathrm{O}$ & - & • & 0 & \\
\hline
\end{tabular}

$\begin{array}{ll} & \text { Legenda } \\ \mathrm{Ca}_{5}\left(\mathrm{PO}_{4}\right)_{3} \mathrm{~F} & \text { Fluorapatita } \\ \mathrm{Ca}_{9} \mathrm{H} \mathrm{PO}_{4}\left(\mathrm{PO}_{4}\right)_{5} \mathrm{OH} & \text { Hidroxiapatita cálcio-deficiente } \\ \mathrm{Ca}_{5}\left(\mathrm{PO}_{4}\right)_{3} \mathrm{OH} & \text { Hidroxiapatita } \\ \mathrm{K}_{4} \mathrm{P}_{2} \mathrm{O}_{7} \cdot 3 \mathrm{H}_{2} \mathrm{O} & \text { Pirofosfato de potássio tri-hidratado } \\ \mathrm{Ca}_{4} \mathrm{P}_{2} \mathrm{O}_{9} & \text { Fostato de cálcio } \\ \mathrm{K} \mathrm{H} \mathrm{C}_{2} \mathrm{O}_{4} \cdot 5 \mathrm{H}_{2} \mathrm{O} & \text { Oxalato de potássio penta-hidratado } \\ \mathrm{C}_{2} \mathrm{Ca} \mathrm{O}_{4} \cdot 2 \mathrm{H}_{2} \mathrm{O} & \text { Oxalato de cálcio di-hidratado } \\ \mathrm{Ca}_{10} \mathrm{~K}\left(\mathrm{PO}_{4}\right)_{7} & \text { Fosfato de cálcio potássio } \\ \mathrm{Ca}_{2} & \text { Fluoreto de cálcio }\end{array}$


Discussão 


\section{Discussão}

\subsection{Discussão da Metodologia}

\subsubsection{Escolha do Tema}

Muitos aspectos relacionados com a hiperestesia dentinária, centrados na grande diversidade de respostas sensoriais, permanecem ainda sem explicação definitiva, confundindo o profissional e comprometendo os resultados clínicos ${ }^{203}$. O acompanhamento das publicações atuais leva, mesmo, a crer que o controle da hiperestesia dentinária cervical representa não somente um problema clínico de difícil resolução, mas também um fenômeno fisiológico de grande complexidade.

As teorias mais freqüentemente sugeridas para explicar o mecanismo da hiperestesia dentinária são: a Teoria das Terminações Nervosas, a Teoria Odontoblástica e a Teoria Hidrodinâmica. A Teoria das Terminações Nervosas e a Teoria Odontoblástica perderam suporte em favor da Teoria Hidrodinâmica, pois foi demonstrado não existir arranjo sináptico entre as terminações nervosas sensoriais e os prolongamentos odontoblásticos, uma vez que estes não se estendem além da metade do comprimento dos túbulos dentinários, que são desprovidos de processos ou nervos, mas preenchidos por fluido extracelular ${ }^{44,231,234,261,266}$. Por esse raciocínio não se explica claramente como um estímulo aplicado à dentina pode estimular fibras nervosas que, aparentemente, não penetram em toda extensão dos túbulos dentinários ou de maneira uniforme na dentina ${ }^{232}$.

Assim, o mecanismo de estimulação nervosa mais aceito, relacionado com a hiperestesia dentinária, é hidrodinâmico por natureza. Ao revisar as evidências que dão suporte à teoria hidrodinâmica da dor, advogadas pelo Dr. Brännström e seus colaboradores $^{24-33}$, pode-se perceber que, em essência, reintroduziram o conceito de Gysi de que as mínimas alterações de movimento do fluido dentinário ou do conteúdo tubular, em 
qualquer direção, ocorrem em resposta aos estímulos térmicos, táteis, osmóticos e evaporativos que atuam na dentina exposta de lesões não cariosas. Porém, diferentemente de Gysi, Brännström acumulou uma grande quantidade de evidências laboratoriais e clínicas para suportar o conceito de que, apesar da metade periférica da dentina ser desprovida de nervos ou processos odontoblásticos, o movimento do fluido na dentina transfere o estímulo superficial deformando os mecanorreceptores pulpares, os quais, em resposta, causam dor ${ }^{175}$. Uma hipótese tacitamente aceita é a de que os túbulos dentinários, para responderem com dor a esses estímulos, devem estar abertos. Assim, uma importante premissa subjacente à teoria hidrodinâmica da dor é que a dentina hiperestésica é uma dentina permeável.

Se o mecanismo de transmissão dos estímulos através da dentina for realizada por meio da movimentação de fluidos, entre outros fatores, a hiperestesia dentinária está diretamente relacionada à dimensão, número e grau de desobstrução dos túbulos. Brännström e colaboradores ${ }^{25,26,30,32}$ e Ishikawa ${ }^{103}$, em 1994, mostraram que o grau de oclusão tubular está relacionado com a permeabilidade dentinária. Vários autores, de fato, reforçaram a teoria hidrodinâmica mostrando microscopicamente a relação positiva entre túbulos abertos na superfície cervical exposta e a hiperestesia ${ }^{1,27,30,32,41,103,160,161,221,226,282,283}$. Ainda, Absi, Addy e Adams ${ }^{1}$, em 1987 e Rimondini, Baroni e Carasi ${ }^{21}$, em 1995, observaram que túbulos dentinários da dentina hiperestésica parecem ser mais numerosos e amplos. Absi, Addy e Adams², em 1989, utilizando-se de réplicas confirmaram esses achados clinicamente. Entretanto, túbulos abertos também foram observados em dentes não hiperestésicos, possivelmente por estarem ocluídos na subsuperfície intratubular ${ }^{1,41,280,281,284}$. Yoshiyama, Suge e Ebsu' ${ }^{284}$, em 1996, observaram estruturas chamadas tubulares ou lâminas limitantes em $75 \%$ dos casos de dentina hiperestésica e especularam a possibilidade dessas estruturas impedirem a precipitação fisiológica de cristais minerais no interior dos túbulos, mantendo-os abertos. 
Essas características dão suporte à teoria da permeabilidade hidrodinâmica da dentina hiperestésica, apoiando a relação entre a hiperestesia e permeabilidade dentinária e antecipam o raciocínio de que o tratamento da dentina hiperestésica depende, em princípio e como conclusão lógica, da compreensão e aceitação da teoria hidrodinâmica e da obliteração dos túbulos dentinários. Assim, torna-se claro o interesse em se estudarem e se aperfeiçoarem procedimentos que modifiquem o padrão hidrodinâmico da dentina e de métodos que possam analisar qualitativa e quantitativamente 0 efeito de agentes terapêuticos da hiperestesia dentinária.

\subsubsection{Escolha dos Materiais}

Uma vez que a hiperestesia dentinária é um fenômeno sensorial complexo, dependente de fatores fisiológicos e emocionais não completamente definidos, não se dispõe até o momento de um produto ou uma terapia que preencha todos os requisitos mencionados por Grossman ${ }^{84}$, em 1935, o que denota, em princípio, que nenhum deles é completamente eficaz. Entretanto, como a teoria mais aceita para explicar o mecanismo da hiperestesia dentinária é a Hidrodinâmica, os agentes mais utilizados e objetos desse estudo são os que interagem com a condutividade hidráulica da dentina, promovendo a obliteração dos túbulos dentinários.

Apesar da escolha dos materiais a serem analisados, considerando as evidências já comprovadas, estar previamente inclinada para os agentes de efeito oclusivo sobre a dentina, não se dispensou uma criteriosa revisão das publicações correntes abrangendo os materiais mais usuais, já que nenhum agente ou terapia foi, ainda, considerado autosuficiente para o alívio da dor hiperestésica da dentina.

Isso posto, dos agentes e terapias expostos o oxalato de potássio foi o material que mais proximamente correspondeu às características de um agente anti-hiperestésico ideal. Por outro lado, o fluorfosfato de sódio acidulado, por ser um agente de larga utilização e 
pela controvérsia sobre sua efetividade, também foi selecionado para este estudo. Além disso, como se percebe no relato histórico de Pashley e Galloway ${ }^{181}$, em 1985, a efetividade dos oxalatos e dos fluoretos há muito vem sendo confrontada na literatura.

Ao longo de anos de estudo, a maioria das propostas para o controle clínico da hiperestesia dentinária tem explorado técnicas que tentam, por diferentes mecanismos, impedir ou limitar o deslocamento do fluido dentinário. Suportado por muitos estudos da literatura mundial sobre o assunto, especialmente os publicados por Pashley e colaboradores $^{159-197}$, desenvolveu-se um produto à base de oxalato de potássio, comercializado com o nome de Oxa-Gel .

O Oxa-Gel tem como componente principal o produto de nome químico oxalato de potássio mono-hidratado, da família química do sal do ácido oxálico, e fórmula $\mathrm{K}_{2} \mathrm{C}_{2} \mathrm{O}_{4} \cdot \mathrm{H}_{2} \mathrm{O}$. É um sal com forma física de cristais incolores, inodoro, com peso molecular de 184,24 e solubilidade de 30 gramas em 100 gramas de água. A solução a 3\% de diluição, preparada a partir desse sal, apresenta $\mathrm{pH} 6,0$, ou seja, próximo da neutralidade, sendo, portanto, necessário ajustá-la para 2,0. Isso porque, em estudo prévio*, a solução de oxalato de potássio mono-hidratado a $3 \%$ e pH 6,0, mostrou alguns aspectos de aplicação negativos, a despeito dos promissores resultados clínicos. O primeiro aspecto diz respeito ao curto tempo de validade da solução, cerca de 30 dias, mesmo quando armazenada sob refrigeração, uma vez que invariavelmente ocorreram contaminação e floculação do produto. O outro fator negativo está relacionado com o aspecto incolor da solução e sua instabilidade na superfície dentinária, o que dificultava sua visualização e o processo de aplicação, respectivamente.

Ainda quanto às características hidrogeniônicas, teoricamente a reatividade das formulações à base de oxalato de potássio com a dentina é também equilibrada pelo $\mathrm{pH}$ do

\footnotetext{
*Pereira, J. C. - comunicação pessoal
} 
medicamento ácido que, somada à natural afinidade do potássio com o cálcio e fosfato, promovem a precipitação de cristais insolúveis sobre a dentina e no interior dos túbulos dentinários $^{113,164,181,277}$. Fica, então, claro o emprego da solução de oxalato de potássio com baixo $\mathrm{pH}$, na expectativa de que o caráter ácido dessa solução produzisse íons livres para a reação de síntese propriamente dita.

Assim, o produto desenvolvido à base da solução de oxalato de potássio monohidratado a 3\%, apresenta como características originais o ajuste do $\mathrm{pH}$ para 2,0 com ácido clorídrico fumegante a $37 \%$, peso molecular 36,46, e a incorporação de carboximetilcelulose em quantidade suficiente para obtenção de um gel com viscosidade desejável para a aplicação clínica. Com a incorporação de carboximetilcelulose, o pH sobe naturalmente para 4,0 o que oferece ao produto uma condição de biocompatibilidade mais favorável, sem perder o potencial reativo. Por outro lado, sob a forma de gel, o oxalato potássio monohidratado tem um prazo de validade maior que dois anos, se armazenado em condições favoráveis de temperatura.

A possibilidade de formular géis mais reativos por influência da variação na concentração das soluções de oxalato de potássio foi reforçada pelas observações de Pashley e Galloway ${ }^{181}$, em 1985, e também Muzzin e Johnson ${ }^{150}$, em 1989, quando mostraram a formação de cristais de tamanhos diferentes, dependendo da concentração do agente ativo. O resultado foi uma obliteração mais efetiva, com cristais depositando-se tanto na embocadura quanto no interior dos túbulos dentinários.

Assim, a partir da composição química original do Oxa-Gel, produto já comercializado derivado do oxalato de potássio mono-hidratado a $3 \%$ e carboximetilcelulose, duas novas formulações à base de oxalato de potássio foram originadas, variando-se a concentração do agente ativo entre $3 \%$ ou $6 \%$ e também o espessante da carboximetilcelulose para o carbopol. As soluções acidificadas de oxalato de potássio mono-hidratado foram obtidas da mesma maneira já descrita para o Oxa-Gel, pela 
solubilização a 3\% e a 6\%do sal de oxalato em água destilada e ajustando-se o pH para 2,0 com ácido clorídrico. Numa das formulações empregada neste trabalho e correspondente ao material Experimental 1, a viscosidade da solução de oxalato de potássio mono-hidratado a $6 \%$ foi aumentada pela adição da carboximetilcelulose, com $\mathrm{pH}$ originalmente neutro, resultando num gel com pH 4,03. Em outra formulação, o material Experimental 2, a reação deu-se entre a solução de oxalato de potássio mono-hidratado a 3\% e o carbopol, com pH mais baixo e mais viscoso, resultando na manutenção do $\mathrm{pH}$ em torno de 2,52 após a formação do gel.

A carboximetilcelulose, do ponto de vista químico, é um polímero aniônico solúvel em água que pode formar um hidrogel orgânico relativamente consistente e, por isso, utilizado como um espessante inerte. Apresenta-se sob a forma de pó ou grânulos de coloração branca e se transforma num gel transparente de aparência acetinada, higroscópico, hidrofílico e resistente a baixas temperaturas. Algumas de suas principais características químicas são o peso molecular médio de aproximadamente 700.000 , pH de 6,5 a 8,5 e viscosidade, ou resistência para fluir, de 1750 cps para a solução a $1 \%$ *.

O carbopol é um polímero acrílico ácido-básico que forma um gel orgânico. É um sistema de fase única, isto é, consiste de macromoléculas orgânicas completamente dispersas de maneira uniforme no líquido. Apresenta-se em forma de pó branco, macio e seco, possui alto peso molecular, pKa 6,0 e pH para a dispersão aquosa de 0,5\% e 1,0\% de 2,7-3,5 e 2,5-3,0, respectivamente. É muito higroscópico e sua viscosidade varia entre 0 a $80.000 \mathrm{cps}$.

Com as variações feitas a partir da formulação do Oxa-Gel, outras alterações além do $\mathrm{pH}$ e da composição química foram observadas nas características dos géis experimentais. A estabilidade térmica dos componentes dos géis, verificada pela análise termogravimétrica (TGA), evidenciou que a maior porcentagem de material orgânico se

\footnotetext{
*Dados fornecidos pela Henrifarma Produtos Químicos e Farmacêuticos Ltda. - SP
} 
volatiliza até uma temperatura média de $100^{\circ} \mathrm{C}$, atingindo um total de $83,33 \%$ para o OxaGel, $74,28 \%$ para o Experimental 1 e $62,85 \%$ para o Experimental 2. Pode-se sugerir, então, que o Oxa-Gel, sob as condições em que foi analisado, é o gel menos estável termicamente, e o Experimental 2, o mais estável. A viscosidade também é diferente entre os géis, variando conforme a taxa de cisalhamento de 0,5 a 100 rpm, de 240.000 a 14.800 cP para o Oxa-Gel, 290.000 a 18.200 cP para o Experimental 1 e de 890.000 a 7.600 cP para o Experimental $2^{*}$.

Em conclusão, na tentativa de produzir melhores formulações para o alívio da hiperestesia e baseando-se em estudos e suposições expostas na literatura, as alterações na composição do Oxa-Gel seguiram o raciocínio de que modificações na concentração e $\mathrm{pH}$ do agente ativo resultaria em alterações na precipitação e na forma dos cristais ${ }^{150,160,181}$. As variações no $\mathrm{pH}$ são responsáveis pela velocidade e quantidade com que os cristais são formados, já que essa reação depende da presença do cálcio ionizado ${ }^{113,181}$. O espessante comanda as diferenças na viscosidade entre os materiais, alterando teoricamente o grau de contato da droga com a dentina, sua difusão para o interior dos túbulos dentinários e sua reatividade com o substrato ${ }^{277}$.

6.1.3. Escolha dos Métodos In Vitro (condutividade hidráulica, microscopia eletrônica de varredura, microanálise de raios $\mathrm{X}$ e difração de raios $\mathrm{X}$ )

A utilização da permeabilidade dentinária como ferramenta para o estudo de agentes terapêuticos deve-se iniciar com um entendimento lógico do papel da permeabilidade na hiperestesia dentinária. O maior protagonista da Teoria Hidrodinâmica e do papel da permeabilidade dentinária, seguindo Martin Brännström ${ }^{24-33}$, é David Pashley ${ }^{159-197}$, construindo o elo entre a permeabilidade dentinária e a avaliação e desenvolvimento dos agentes terapêuticos para o tratamento da hiperestesia dentinária. Também é importante ressaltar a contribuição de Martin $\mathbf{A d d y}^{1-6}$ apresentando muitos artigos sobre a avaliação

\footnotetext{
*Pesquisa realizada no CCDM-UFSCar.
} 
clínica dos agentes anti-hiperestésicos. De acordo com a Teoria Hidrodinâmica, a hiperestesia dentinária deve ser proporcional à permeabilidade dentinária, isto é, se o movimento do fluido no interior dos túbulos dentinários aumenta, também aumenta a hiperestesia, sendo a condição de abertura dos túbulos a variável mais importante ${ }^{175,235}$.

A história da hiperestesia dentinária, suas implicações clínicas e seu tratamento não podem ser descritos sem uma revisão dos métodos experimentais utilizados para avaliar a permeabilidade dentinária laboratorialmente. A revisão da literatura sugere que, ao menos durante os primeiros anos de pesquisa ativa sobre hiperestesia dentinária, as técnicas in vitro se desenvolveram a passos mais rápidos do que a investigação clínica, abrindo novas linhas de pesquisa. Ademais, como exposto por Sena ${ }^{235}$, em 1990, na maioria das pesquisas científicas, o uso de um modelo de laboratório para ilustrar a operação de um mecanismo postulado e testar sua validade pela aplicação dos fatores físicos e químicos esperados é essencial para o entendimento da natureza das observações clínicas. Conforme declararam Pashley et al. ${ }^{167}$, em 1981, é mais conveniente estudar a permeabilidade dentinária in vitro porque, exceto a variabilidade inerente à dentina, outras importantes variáveis e algumas características da superfície dentinária podem ser mais facilmente controladas. Considera-se, ainda, que os dentes recém-extraídos não contêm processos odontoblásticos nem variações de pressão intrapulpar, presentes na dentina estudada in vivo, e que podem alterar a permeabilidade ${ }^{72}$.

A importância dos métodos laboratoriais é aumentada pela natureza usualmente difícil de se estudar a situação clínica da hiperestesia dentinária. Além do que, a despeito do consenso publicado por Holland et al. $^{97}$, em 1997, fruto da discussão de um comitê sobre hiperestesia dentinária, a dificuldade de execução e a subjetividade são características inerentes aos experimentos clínicos sobre permeabilidade e hiperestesia dentinária. Quando se considera a diversidade das metodologias empregadas, o recrutamento e o manejo do pacientes, a correlação entre o diagnóstico versus resposta do paciente e observação clínica dos sintomas, a dificuldade de mensuração da dor e, ainda, a influência do 
largamente discutido efeito placebo, fica claro que os métodos de laboratório são parte essencial do processo de pesquisa ${ }^{235}$.

Entretanto, apesar das consideráveis informações obtidas sobre as características de permeabilidade da dentina humana por intermédio de técnicas laboratoriais, estudos clínicos $^{38,46,47,59,69,70,96,148,150,204,205,206,241,263,272}$ comparativos são necessários para a avaliação da efetividade dos métodos e aplicabilidade dos resultados obtidos in vitro. Também importantes são os estudos realizados in vivo, especialmente em cães $^{128,167,170,172,173,182,192,277}$, pois alguns ensaios requerem, por exemplo, o uso de isótopos radioativos, que não podem ser praticados em humanos.

A permeabilidade dentinária, segundo Pashley e seus colaboradores ${ }^{166,188,197}$, pode ser mensurada quantitativamente mediante de três coeficientes independentes. São eles: a condutividade hidráulica, o coeficiente de permeabilidade dos solutos e o coeficiente de reflexão dos solutos sendo que o transporte de solutos através da dentina pode se dar por filtração, difusão e iontoforese. Geralmente, os estudos quantitativos de permeabilidade envolvem medições por difusão e filtração através da dentina. Apesar de serem valiosas as informações oferecidas considerando o transporte difusivo, as medições da permeabilidade difusiva da dentina consomem muito tempo, tanto in vitro quanto in vivo. Além de que, conforme a teoria hidrodinâmica, é o movimento do líquido, ou a filtração, o responsável pela transformação de uma variedade de estímulos em resposta sensorial ${ }^{166,177}$. Esse tipo de movimento de fluido, objeto desse estudo, pode ser adequadamente quantificado pela medição da condutividade hidráulica da dentina.

A razão mais significativa para que a condutividade hidráulica tenha sido selecionada dentre os métodos quantitativos de estudo da permeabilidade dentinária, além da facilidade de execução, foi a possibilidade de que essa metodologia permite de padronização de variáveis importantes. Pode-se controlar a área da superfície dentinária a ser experimentada, a espessura da dentina e a pressão hidrostática aplicada ${ }^{166}$. 


\subsubsection{Condutividade Hidráulica}

Na tentativa de minimizar a grande variação na permeabilidade de dente para dente e de uma região do mesmo dente para outra ${ }^{76,186}$, procurou-se nesse estudo utilizar, preferencialmente, terceiros molares não irrompidos de paciente jovens, acreditando-se que teriam quantidade mínima de dentina secundária e esclerosada ${ }^{53,243,252}$.

A solução determinada para a preservação dos dentes no melhor estado de conservação possível e utilizada por vários autores foi a solução de timol $^{131,195,286}$. A solução de azido de sódio também é muito utilizada pelos autores ${ }^{61,63,75,179,180,189,200,213,215,239,253,255}$. Já que o armazenamento dos dentes pode interferir na permeabilidade dentinária ${ }^{73,76,247}$, é largamente admitido que tanto a solução de timol quanto a de azido de sódio não exercem efeito, seja no conteúdo orgânico ou inorgânico da dentina ${ }^{85}$, além de impedirem eficientemente o crescimento bacteriano ${ }^{76}$. Os dentes se mantiveram a uma temperatura de $4^{\circ} \mathrm{C}$, como se refere a grande maioria dos estudos ${ }^{73}$.

Procurou-se, no presente trabalho, limitar o tempo em que os dentes ficaram imersos em solução de timol a $4^{\circ} \mathrm{C}$ a um mês pós-extração, ainda que isso pareça ter uma mínima influência na permeabilidade dentinária ${ }^{156}$, pois a maior parte da dentina utilizada é de uma região provavelmente livre de processos odontoblásticos ${ }^{27,266}$. Reforçando essas informações, o trabalho de Pashley, Livingston e Greenhill ${ }^{186}$, em 1978, estabelece que a presença de processos odontoblásticos nos túbulos dentinários é responsável apenas por $7,48 \%$ da redução da filtração. Já para Goodis, Marshall e White ${ }^{76}$, em 1991, e Goodis et al. $^{73}$, em 1993, o tempo de armazenamento prolongado dos dentes pode reduzir a permeabilidade dentinária. De qualquer modo, os dentes foram utilizados o mais rapidamente possível após sua extração.

Os espécimes dentinários destinados aos ensaios de condutividade hidráulica in vitro podem estar na forma de discos ou de segmentos coronários, sendo que os discos de dentina, escolhidos para esta investigação, têm sido empregados por muitos 
ser o modelo in vitro o mais representativo da condição in vivo.

Os discos de dentina, segundo Mordan, Barber e Gillam ${ }^{146}$, e Gillam, Mordan e Newman ${ }^{72}$, em 1997, apesar das aparentes limitações, são reconhecidamente um sistema adequado para experimentar, in vitro, o efeito dos agentes anti-hiperestésicos na deposição superficial e na oclusão tubular, assim como os efeitos desses agentes no deslocamento do fluido através da dentina. Aespessura uniforme, passível de ser reduzida por desgaste, e a área de superfície, definida e padronizada pela própria câmara de filtração, são características que elegem o disco de dentina como um modelo reprodutível ${ }^{166}$.

Segmentos coronários também foram o modelo na investigação de diversos pesquisadores $^{73,75,76,80,131,161,171,179,186,198,200,213,239,253,286}$ e podem ser utilizados para experimentos de diferentes propostas, relacionadas à permeabilidade dentinária, como estudos sobre adesão ${ }^{171,201}$ e microinfiltração de materiais ${ }^{180}$. Entretanto, a complexidade geométrica dos segmentos coronários exerce influências importantes na caracterização quantitativa da permeabilidade dentinária. Quando os segmentos coronários são utilizados, a área total de superfície dentinária é quase impossível de ser quantificada e mantida constante em função da variabilidade da espessura de esmalte e da irregularidade do contorno da junção amelodentinária. Além disso, as variações biológicas da morfologia 260,262 do corno e da câmara pulpar provocam, também, variações importantes na espessura dentinária, entre a cavidade ou a superfície a ser estudada e o teto da câmara. Via de regra, a espessura dentinária é maior no centro e menor na altura dos cornos pulpares, isto é, nas áreas mais permeáveis. Como os cálculos de permeabilidade requerem um conhecimento preciso tanto da área de superfície quanto da espessura dentinária, o uso de cavidades é evitado para os testes de filtração. Por essa razão, vários autores indicam a utilização de discos de dimensões conhecidas ${ }^{156}$. 
O método para a obtenção dos discos de dentina, a partir de terceiros molares extraídos e, adotado por diversos autores ${ }^{36,81,134,156,185,217}$, foi descrito primeiramente por Outhwaite, Livingston e Pashley ${ }^{156}$, em 1976, que seccionava transversalmente a coroa dos terceiros molares com brocas em alta velocidade e sob refrigeração, produzindo discos exclusivamente de dentina na sua porção central, porém de mais difícil padronização e acabamento. No presente estudo, a exemplo de outros ${ }^{37,135,161,174,181,189,190,191,194,196}$, foram utilizados discos de diamante adaptados a uma máquina de corte específica para adquirir espécimes de aproximadamente $1 \mathrm{~mm}$ de espessura, com características padronizadas e de fácil obtenção.

Como a permeabilidade dentinária e a área de superfície podem ser diferentes, dependendo da distância da câmara pulpar, cuidados necessários foram tomados para que os discos fossem removidos da porção de dentina coronária mais central entre o esmalte oclusal e a polpa, evitando que remanescessem resíduos de esmalte decorrentes das cicatrículas e fissuras ou de áreas correspondentes aos cornos pulpares, que poderiam, respectivamente, reduzir de forma significativa a filtração através da dentina, ou exacerbá-la, de modo a comprometer de forma grosseira a padronização e os cálculos de condutividade.

Complementarmente, dados fornecidos por Outhwaite, Livingston e Pashley ${ }^{156}$, em 1976, mostraram que as reduções na espessura dentinária dos discos no lado do esmalte oclusal promoveram um aumento de 6 a 8 vezes na permeabilidade, suportando a idéia de que a metade pulpar da espessura dos discos é mais permeável do que a metade oclusal, mesmo quando ambas têm medidas semelhantes, pois a área de superfície de dentina tubular aumenta devido à redução relativa da quantidade de dentina intertubular, ou seja, há maior número de túbulos por unidade de área, além da diminuição da tortuosidade em direção à polpa.

No presente trabalho, a etapa de obtenção dos discos foi marcada como uma das mais importantes de todo o procedimento. $\mathrm{Na}$ eventualidade de terem remanescido restos 
de esmalte oclusal ou dos espaços dos cornos pulpares, os discos eram reduzidos com lixas para que fosse garantida sua padronização e uniformidade quanto à espessura e às características de superfície.

Os discos de dentina, apesar de serem reprodutíveis, têm como característica a permeabilidade heterogênea, mesmo tendo espessura uniforme e nenhuma evidência de cornos pulpares ou de esmalte, na superfície oclusal ${ }^{161,217}$. Mordan, Barber e Gillam ${ }^{146}$, em 1997, explicam que as variações na superfície dentinária ocorrem não apenas nos túbulos de um disco para o outro, mas também ao longo da superfície de um mesmo disco, pois os túbulos das regiões próximas aos cornos pulpares têm um maior diâmetro e número do que os da periferia e são orientados perpendicularmente à superfície do disco. Verificaram que a permeabilidade da dentina coronária é maior nas proximidades dos cornos pulpares e, portanto, oferecem uma superfície mais apropriada para o teste. Também Maroli, Khera e Krell ${ }^{130}$, em 1992, concordam com essa variabilidade da dentina, reforçando ainda que o terço cervical é o mais permeável e microscopicamente apresenta maior quantidade de túbulos abertos.

Pashley et al. ${ }^{161}$, em 1987, para compensar a variabilidade regional da dentina, sugeriram que os estudos de condutividade hidráulica da dentina utilizem a maior área de superfície possível, pois as medições no centro do disco geralmente superestimam a Lp, uma vez que o anel de borracha pode coincidir parcialmente com as áreas dos cornos pulpares. Conscientes do problema, sempre que as dimensões dos discos de dentina permitiram, a área de dentina exposta de $0,282 \mathrm{~cm}^{2}$ era utilizada preferencialmente a área de $0,178 \mathrm{~cm}^{2}$, reservada para uma minoria de espécimes.

Um dos fatores significantes para o estudo da permeabilidade dentinária é a criteriosa seleção dos discos, pois a caracterização da dentina após os tratamentos pode ser confundida por diversos fatores resultantes das variações morfológicas inerentes a esse substrato $^{140,146}$ ou mesmo decorrente de artefatos produzidos pelos procedimentos de 
preparo $^{146}$. A seleção dos discos abrangeu, além do exame visual da superfície dentinária com lupa estereoscópica, também a análise dos índices de filtração previamente aos ensaios de condutividade hidráulica propriamente dito, objetivando a homogeneidade da amostragem do ponto de vista da permeabilidade dentinária, facilitando a comparação dos resultados. Esse procedimento resultou na utilização de discos com índices de filtração menos discrepantes entre si, além de possibilitar a remoção de resíduos do interior dos túbulos pelo fluxo de líquido, minimizando as interferências dessas variáveis nos valores de filtração.

Uma ilimitada linha de pesquisa abriu-se, em 1974, quando Outhwaite, McKenzie e Pashley ${ }^{157}$, planejaram e desenvolveram um dispositivo para estudar a permeabilidade dentinária, padronizando a área de superfície para a filtração ou difusão.

Muitas alterações no desenho da câmara de filtração e do sistema desenvolvidos foram propostas para acomodar as variações na forma dos espécimes e de pressão necessárias para diferentes aplicações. Nos estudos iniciais, a pressão era regulada variando-se a altura do reservatório da solução de filtração, situada acima do espécime de dentina, adaptado numa câmara fechada de ambos os lados ${ }^{81,135,186,190,191,193,217}$. Mais tarde, utilizando a câmara preconizada por Outhwaite, McKenzie e Pashley ${ }^{157}$, em 1974, foi adicionada ao sistema uma micro-seringa, facilitando o posicionamento da bolha de ar previamente às medições ${ }^{172,194,196}$. Pashley e Galloway ${ }^{181}$, em 1985, novamente modificaram o sistema, introduzindo uma câmara de pressão ligada a um cilindro de nitrogênio para a simulação da pressão hidrostática. Esse modelo, utilizado para vários estudos subseqüentes ${ }^{61,63,183,184,237}$, foi reproduzido para a realização dos ensaios de condutividade hidráulica da presente investigação. Outros modelos ainda surgiram, utilizando o mesmo sistema pressurizado para a adaptação de segmentos coronários ao invés de discos de dentina ${ }^{75,161,179,180,200,213,215,239,255}$. Na tentativa de tornar mais precisa a mensuração do deslocamento da bolha de ar, especialmente quando o fluxo é mais lento, 
sob pressões mais baixas produzidas sem a câmara de pressão, em alguns trabalhos $^{42,169,286}$ as medições foram realizadas utilizando-se um sistema computadorizado denominado Flodec, onde raios infravermelhos e receptores foto-sensíveis, acoplados ao capilar de vidro, detectam qualquer movimento da bolha de ar na ordem de micrometros.

Em quase todos os experimentos realizados por Pashley ${ }^{166}$, as medições são quantitativas e reprodutíveis dentro de um mesmo espécime. Se uma informação controle é coletada, e forem expressas respostas às variáveis experimentais como percentagem dos valores controle, tem-se uma excelente medição relativa da permeabilidade dentinária, utilizando cada espécime como seu próprio controle. Assim, a permeabilidade mínima pôde ser prevista por meio da criação de uma smear layer experimental, simulando as condições clínicas. Para definir o outro extremo, isto é, a máxima permeabilidade, a remoção da smear layer foi viabilizada utilizando o EDTA a 0,5 M com pH 7,4. Corroborando esses critérios, Pashley, Livingston e Greenhill ${ }^{186}$, em 1978, observaram que a alteração na superfície provocada pela smear layer foi responsável por $86 \%$ da resistência total à movimentação dos fluidos e, Reeder et al. ${ }^{217}$, em 1978 e Pashley et al. $^{167}$, em 1981, informaram que sua remoção com ácidos provoca um aumento significante de 5 a 40 vezes nos valores de filtração. Na ausência destes pontos de referência, isto é, permeabilidade dentinária mínima e máxima, a interpretação dos dados de condutividade hidráulica referentes ao potencial de ação dos agentes anti-hiperestésicos torna-se mais crítica ${ }^{166}$.

In vivo, a smear layer provavelmente resulta do desgaste, escovação, aglomerações de proteínas, placa, etc ${ }^{52,160,161,176}$. In vitro, no espécime de dentina, essa camada é meramente um artefato resultante do corte ou do desgaste do espécime e varia dependendo da superfície que está sendo cortada ou desgastada, das irregularidades da lâmina de corte ou do instrumento de desgaste, da pressão aplicada e da refrigeração ${ }^{58,177,214}$.

Ficou clara a necessidade de simular uma smear layer padronizada e não exageradamente espessa ao se constatar que sua espessura, quando simulada com lixas in 
vitro, pode variar de 0,5 a $5 \mu m^{29,33}$ e que, se obtidas com discos de diamante para a obtenção dos espécimes, como neste estudo, pode alcançar de 10 a $15 \mu \mathrm{m}^{190}$.

Pashley, em $1990^{166}$, observou que a granulação da lixa tem uma profunda influência no efeito da smear layer resultante na redução da permeabilidade dentinária. De acordo com esse autor, quanto mais fina a lixa, maiores serão as reduções nos valores da permeabilidade. Vários autores acreditam que o método mais adequado de simular in vitro a condição in vivo da smear layer seria utilizando uma lixa abrasiva de granulação 320, adaptada a uma máquina para desgaste que permita um controle preciso da pressão e da temperatura, sugerindo o lixamento do espécime por cinco segundos a uma velocidade de 108 rpm, sob 500 gramas de força vertical e em água corrente $160,171,179,189,215,239$. De acordo com esses estudos e adaptados à nossa realidade, a smear layer, nesse estudo, foi simulada da mesma maneira prescrita por Pashley, porém sob pressão digital de um mesmo operador.

A presença da smear layer proporciona grande quantidade de íons cálcio e fosfato disponíveis para reagir com os diferentes agentes aplicados sobre a dentina. Em contrapartida, sua remoção com agentes químicos diminui o número de íons e, conseqüentemente, número de precipitados. Assim, dependendo do pré-tratamento da smear layer, a reatividade da superfície dentinária será diferente e também a quantidade de íons cálcio e fosfato disponíveis para participar de reações químicas ${ }^{56}$. Entretanto, Yamamoto et al. ${ }^{277}$, em 1996, ressaltaram que se a smear layer não for removida com condicionamento ácido previamente ao tratamento, a maior parte dos cristais estará localizada apenas na superfície dentinária e não no interior dos túbulos, indicando que a condição da dentina exposta pode ser crítica quando se estuda clinicamente o tratamento da dentina hiperestésica. Em estudo preliminar ${ }^{208}$, observou-se a completa cristalização da smear layer superficial e a obliteração dos túbulos pelos smear plugs. (Figura 38). 

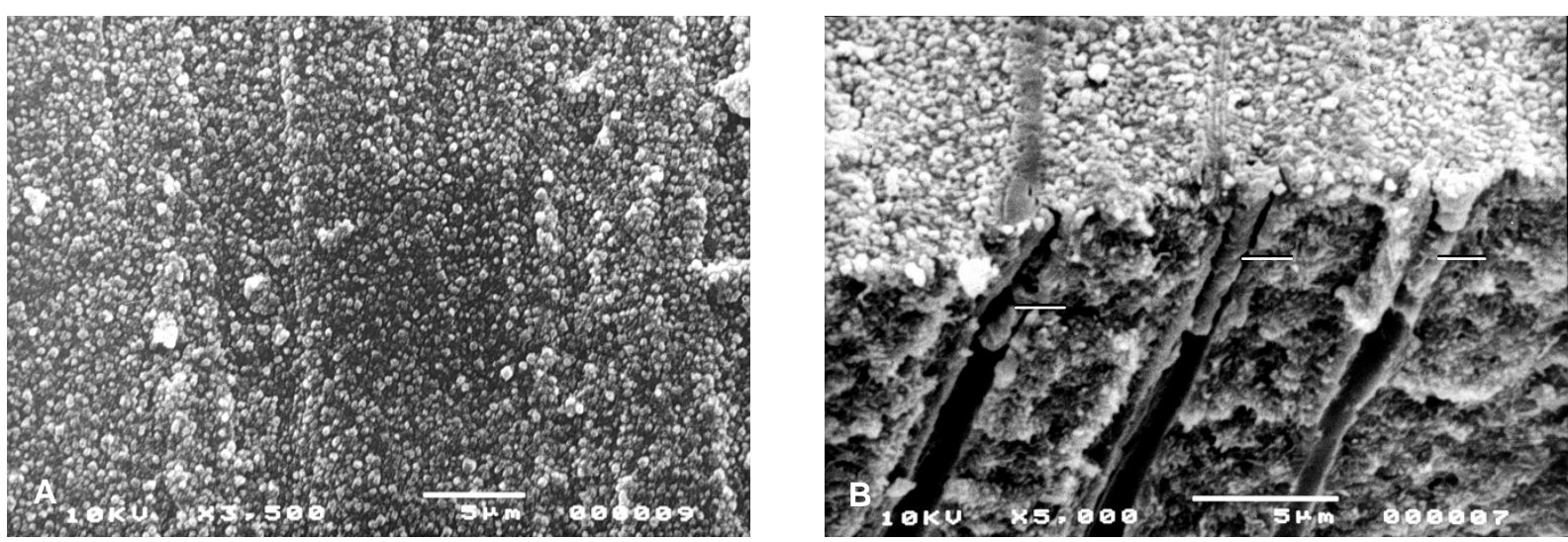

Figura 38 - A - Aparência da smear layer cristalizada devido à reação com o oxalato de potássio; B - no espécime fraturado, notam-se densos smear plugs no interior dos túbulos dentinários impedindo a penetração dos cristais depositados nas embocaduras.

Os autores, para remover a smear layer e simular a dentina hiperestésica, têm utilizado vários agentes como o EDTA a $0,5 \mathrm{M}^{112,159,179,253}$, ácido cítrico a $6 \% \%^{61,131,170,173,180,181,183,184,190,193,194,196,200}$ ou a $50 \%{ }^{63,81,134,135,161,174,186,192,217}$ e ultra-som ${ }^{1,166,248}$. Segundo Blomlof e Lindskov ${ }^{15}$, em 1997, dos condicionadores ácidos utilizados clinicamente o EDTA é o único que exerce efeito desmineralizante por meio de cátions quelantes bivalentes em $\mathrm{pH}$ neutro, enquanto que o ácido fosfórico atua através de $\mathrm{pH}$ baixo e dissolve ou erosiona a superfície mineralizada, e o ácido cítrico funciona pela combinação dos dois mecanismos. Com relação ao ultra-som, os autores observam incompleta remoção dos resíduos com esse recurso físico ${ }^{72,146,166}$.

Com relação ao condicionamento com ácido cítrico, Brännström e Johnson ${ }^{29}$, em 1974 e Pashley, Michelich e Kehl ${ }^{190}$, em 1981, relataram a remoção de praticamente toda a smear layer, assim como da superfície dentinária peritubular dos túbulos, desobstruindo e ampliando excessivamente a abertura dos túbulos dentinários. Em estudos de Pashley ${ }^{174,217}$, a condutividade hidráulica aumentou de 15 a 32 vezes após o condicionamento com ácido cítrico a 50\%. McAndrew e Kourkouta ${ }^{132}$, em 1995, relataram que a concentração de ácido cítrico a 0,2\%, aplicado durante dois minutos, é insuficiente 
para remoção da smear layer e, a $50 \%$, torna-se excessivamente desmineralizante e erosivo.

O condicionamento da dentina com ácidos fracos e agentes quelantes como o EDTA, além do aumento da permeabilidade dentinária devido à remoção da smear layer, preserva boa quantidade da matriz dentinária mineral subjacente ${ }^{166}$, revela as embocaduras dos túbulos dentinários e exibe as fibras colágenas mantendo, eventualmente, os smear plugs $^{15,33,167,172}$. Além desses fatores, foram consideradas a recomendação de Pashley ${ }^{171}$, em 1988, e a divulgação de Brännström, Nordenvall e Glantz $^{33}$, em 1980, de que as soluções contendo EDTA possuem a capacidade de remover a smear layer de dentes humanos, in vivo, sem ampliar demasiadamente a abertura dos túbulos ou destruir a dentina peritubular. Essas recomendações fizeram com que o EDTA fosse eleito para o presente estudo, tanto para a limpeza da dentina previamente à obtenção da smear layer experimental quanto na simulação da dentina hiperestésica, para a medição da permeabilidade máxima (Figura 39).

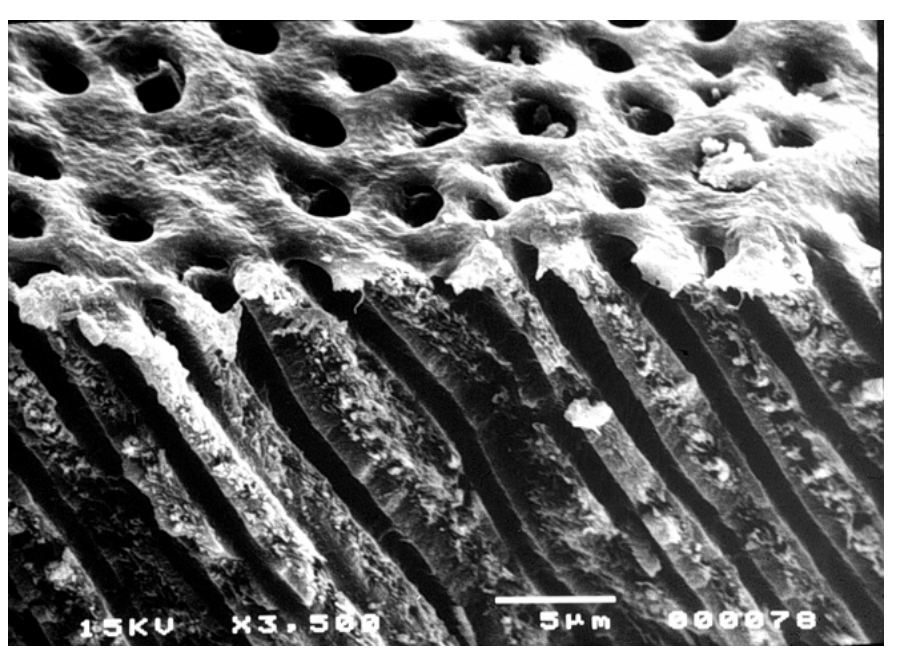

Figura 39 - Aspecto da dentina após ter sido limpa com EDTA a $0,5 \mathrm{M}$. Percebe-se a ausência da smear layer superficial revelando as embocaduras tubulares desobstruídas e eventuais resíduos dos smear plugs no interior dos túbulos.

As observações a respeito dos efeitos da dieta ácida na dentina hiperestésica ajudam a explicar porque os benefícios dos tratamentos anti-hiperestésicos são tão rapidamente revertidos. Segundo Addy, Absi e Adams³, em 1995, as dietas ácidas, 
especialmente o suco de laranja, removem os componentes dos dentifrícios das superfícies dentinárias e abrem os túbulos pela dissolução da smear layer, particularmente quando combinada com a escovação.

Estudo recente sobre condutividade hidráulica, utilizando a mesma metodologia do presente trabalho, revelou que os sucos de laranja natural e artificial, com pH em torno de 4,0 têm ação significante na dissolução da smear layer, abertura tubular e aumento da permeabilidade*. Pashley, Michelich e KehI ${ }^{190}$, em 1981, também observaram que o condicionamento com ácido cítrico a $6 \%$ durante um minuto, remove praticamente toda a smear layer assim como pequena porção da superfície dentinária peritubular.

Isso posto, e agindo em conformidade com outros trabalhos encontrados ${ }^{181,183,184}$ a dentina após ter sido tratada com os agentes anti-hiperestésicos, foi desafiada com ácido na intenção de quantificar a resistência da obstrução tubular oferecida pelo tratamento. O ácido cítrico a $6 \%$, aplicado por um minuto, foi selecionado para simular os efeitos da exposição da dentina ao ambiente oral, uma vez que está presente nas frutas cítricas e por compor parte das bebidas de teor ácido, reconhecidamente coadjuvantes da hiperestesia dentinária ${ }^{3,132}$.

As soluções de filtração utilizadas na maior parte dos estudos de condutividade hidráulica variam principalmente entre a solução Krebs-Ringer ${ }^{81,134,135,156,174,185,186,190,217}$, solução salina ${ }^{63,161,170,181,183,184,189,191,193,198,200,201255}$ e água ${ }^{131,194}$.

Após ensaios de condutividade hidráulica, Pashley, Stewart e Galloway ${ }^{194}$, em 1984, concluíram que a presença tanto de sais inorgânicos como de proteínas nas soluções de filtração, em comparação com a água, são responsáveis por mais de $50 \%$ de redução na filtração na dentina exposta a jatos de ar. Isso ocorre porque, presumivelmente, a evaporação da água das soluções leva ao aumento da concentração dos sais inorgânicos ou orgânicos remanescentes, levando a cristalização ou precipitação de sais desconhecidos 
quando seus componentes excedem seus respectivos produtos de solubilidade. Na presente investigação, a filtração foi realizada com água deionizada, desprovida de qualquer componente mineral ou orgânico que pudesse interferir na filtração ou reagir com os agentes anti-hiperestésicos. Além disso, o reservatório de água da câmara de pressão era periodicamente limpo e a água deionizada trocada a intervalos regulares para reduzir a possibilidade de obstrução retrógrada dos túbulos dentinários, seja por bactérias ou por resíduos inorgânicos.

A maioria dos estudos laboratoriais emprega pressões bem maiores do que a pressão pulpar fisiológica $35,36,81,134,168,181,186,191,196,217$, estimada em valores muito variáveis que vão de $32,6 \mathrm{~cm} \mathrm{H}_{2} \mathrm{O}^{192}$ e $42 \mathrm{~cm} \mathrm{H}_{2} \mathrm{O}^{128}$ em dentes cães, $15 \mathrm{~cm} \mathrm{H}_{2} \mathrm{O}$ em gatos ${ }^{269}$ e 14,1 $\mathrm{cm} \mathrm{H}_{2} \mathrm{O}$ em humanos ${ }^{42}$. Nesse estudo, a pressão aplicada de $703,1 \mathrm{~cm} \mathrm{H}_{2} \mathrm{O}$ ou 10 psi é muito superior as pressões fisiológicas, mas como justificam Merchant, livingston e Pashley ${ }^{134}$, em 1977, e Richardson, Tao e Pashley ${ }^{220}$, em 1991, é uma pressão utilizada por conveniência, proporcionando suficiente movimentação de líquido para uma medição precisa em poucos minutos.

A pressão hidrostática aplicada não deve ser motivo de grandes preocupações na opinião de Pashley et al. ${ }^{173}$, em 1983, pois estudando a permeabilidade dentinária de cães in vivo, concluíram que a pressão do tecido pulpar não varia o suficiente para causar grandes erros nos cálculos de Lp. Entretanto, in vitro, Reeder et al. ${ }^{217}$, em 1978, demonstraram que a filtração através da dentina, condicionada ou não, aumenta linearmente conforme o aumento gradual da pressão hidrostática de 60 para 120 e para $240 \mathrm{~cm} \mathrm{H} \mathrm{H}_{2} \mathrm{O}$. Já para Camps et al. ${ }^{35,37}$, em 1996 e em 1997, além da variação da pressão, também o tempo de filtração pode, de certa maneira, alterar os valores de condutividade hidráulica da dentina. Explicaram que as pressões mais altas provocam o aumento da resistência intratubular por meio da compressão do conteúdo interno dos túbulos contra 
suas paredes, possivelmente subestimando os valores de filtração. In vivo, utilizando pressão fisiológica pulpar, os resultados são mais próximos da realidade, pois o conteúdo intratubular não é afetado e nem há alteração dos valores com o tempo de filtração. Ao recomendar a utilização de pressão e tempo de filtração reduzidos, os autores alertam para a necessidade da utilização de um dispositivo de alta precisão, que permita a medição de pequenos deslocamentos de fluido.

Apesar de não haver diferença nas medições da condutividade hidráulica in vitro quando a direção de filtração foi invertida, há diferença nas medições in vivo, nas quais a condutividade hidráulica medida da polpa para o esmalte é maior do que a alcançada na direção oposta ${ }^{169,192,269}$. Segundo os resultados de Pashley, Livingston e Greenhill ${ }^{186}$, em 1978, a reversão da direção de filtração in vitro após uma semana da extração dos dentes produziu menor mudança no grau de filtração do que por filtrações realizadas imediatamente após a extração devido, presumivelmente, à autólise dos remanescentes do tecido pulpar, que se desintegram lentamente após esse intervalo de tempo, diminuindo a resistência do fluido e eliminando o efeito direcional sobre o deslocamento do fluido ${ }^{186}$. Assim, levando em conta as informações mencionadas em estudos anteriores ${ }^{186}$, na presente investigação os dentes ficaram armazenados por mais de uma semana antes de serem obtidos os discos de dentina. Os discos foram selecionados após sofrerem uma pré-filtração, eliminando-se os que proporcionaram as medições iniciais mais discrepantes. Essa conduta contribuiu provavelmente para a eliminação do conteúdo remanescente dos túbulos dentinários antes dos testes de filtração propriamente ditos. Além disso, como a fonte de pressão que movimenta os líquidos através da dentina in vivo é a polpa e a maior parte dos estímulos externos provoca o movimento em direção ao meio externo, no presente estudo a direção da filtração foi conduzida no sentido polpa-esmalte.

A eleição das condições de pré-tratamento impostas ao substrato dentinário antes da aplicação do oxalato de potássio ou do fluoreto de sódio baseou-se em estudo preliminar 
realizado por Pereira, Segala e Carvalho ${ }^{208}$, em 1996, onde os materiais antihiperestésicos foram aplicados na dentina sob cinco condições prévias: seca com ar, seca com papel, mantida molhada, acidificada e seca com ar, acidificada e seca com papel e, finalmente, sobre a smear layer remanescente. A análise da dentina, em quaisquer dessas condições de pré-tratamento, analisadas sob microscopia eletrônica de varredura, mostrou escores de precipitação cristalina e de oclusão tubular similares, exceto frente ao fluoreto de cálcio, que não evidenciou formação de cristais. Esses resultados, qualitativos e subjetivos quanto ao método de análise, estimularam a investigação quantitativa da condutividade hidráulica desses materiais e condições de pré-tratamento, objetivando a interpretação dos resultados por intermédio de um método de análise de imagens computadorizadas ${ }^{18}$.

\subsubsection{2 - Microscopia Eletrônica de Varredura}

Ao estudar os diferentes aspectos relacionados com a permeabilidade dentinária, comumente os autores têm associado o método de análise quantitativa de condutividade hidráulica com outros métodos de avaliação qualitativas e/ou quantitativas, envolvendo, especialmente, a microscopia eletrônica de varredura. Nos experimentos em que participam Pashley e seus colaboradores ${ }^{60,63,81,135,174,181,183,184,190,200,213,237,239,253,286}$, um dos autores que mais publicou sobre este assunto, freqüentemente se encontram as medições de condutividade hidráulica associadas às imagens de microscopia eletrônica de varredura, assim como outros autores que também se utilizaram desta associação ${ }^{141,144,246,248,249}$. A microscopia eletrônica pode ser suplementada pelas microanálises de raios $\mathrm{X}$, identificando os componentes químicos resultantes do tratamento da superfície dentinária e pelo estudo da difração de raios $\mathrm{X}$, quando se procura identificar as fases resultantes das reações sobre a dentina ${ }^{141,144,251,268}$

Discos de dentina, obtidos da mesma maneira que para os testes de condutividade hidráulica, são também recomendados para as observações em microscopia eletrônica de varredura. Absi, Addy, Adams ${ }^{3}$, em 1995, sugerem que esse modelo seja adotado como 
método usual, na tentativa de padronizar os experimentos que avaliam in vitro o potencial dos agentes anti-hiperestésicos na oclusão dos túbulos dentinários.

Outra preocupação na condução desse experimento, também manifestada por Ling et al. $^{124}$ e outros investigadores ${ }^{69,146}$, foi a utilização de um mesmo disco de dentina para fornecer, ao mesmo tempo, as superfícies experimentais e os controles correspondentes. Convém lembrar que para essa etapa do experimento elegeu-se a dentina seca com ar como condição de pré-tratamento, variando-se apenas o agente anti-hiperestésico, na seqüência dos ensaios. Dessa maneira, as quatro situações a que cada espécime foi submetido, representadas pela manutenção da smear layer, limpeza com EDTA, aplicação do agente experimental e desafio com ácido cítrico, foram todas realizadas sobre o mesmo substrato dentinário. Para tanto, o disco de dentina foi delimitado de forma que cada uma das quatro situações fosse acomodada em seus respectivos quadrantes na superfície do disco. Ao mesmo tempo, a fratura dos discos, da maneira com que foi planejada, possibilitou a visualização longitudinal dos túbulos dentinários nas mesmas regiões em que a superfície foi analisada, facilitando o estudo e a correlação entre as imagens. Encontrou-se grande dificuldade para obtenção de imagens longitudinais que pudessem ser analisadas, pois a fratura via de regra ocorria na região de dentina intertubular, sem expor os túbulos em toda sua extensão ou mascarando-os nas regiões de maior concentração de cristais.

Ainda do ponto de vista da utilização do mesmo espécime para os procedimentos simultâneos de teste e controle, seja para a análise da superfície ou da espessura dos espécimes, entende-se que esta seja uma condição que permite avaliar efeitos idênticos de condicionamento e de defeitos de superfície dos espécimes, em regiões em que o diâmetro, a orientação e a extensão dos túbulos são semelhantes ${ }^{146}$.

Para minimizar o efeito das diferenças topográficas, também se propõe que a área de exame seja localizada na altura dos cornos pulpares, pois os túbulos nesse local possuem maior diâmetro do que os da periferia do disco dentinário e estão, geralmente, 
orientados perpendicularmente à superfície dentinária, fornecendo uma excelente área de teste. E, ainda, Greenhill e Pashley ${ }^{81}$, em 1981, posicionaram-se afirmando que a avaliação da profundidade de penetração pode ser enganosa devido à possibilidade de que durante o processo de fratura do disco os precipitados se desloquem dos túbulos.

A escolha da condição de pré-tratamento do substrato dentinário para a análise microscópica da reatividade da dentina com o oxalato de potássio ou com o fluoreto de cálcio obedeceu à indicação dos resultados da análise quantitativa de condutividade hidráulica. Dessa forma, a condição da dentina seca com ar, como pré-tratamento à aplicação dos agentes experimentais, foi a escolhida pois, como exposto na Tabela 10, essa condição obteve o melhor desempenho quando se considerou o tratamento de superfície como efeito principal. Também nos Gráficos 5 e 6 observa-se que a dentina seca com ar, comparativamente às demais condições, é a que proporciona filtrações menos discrepantes entre os materiais anti-hiperestésicos, além de ser viável clinicamente.

Em estudos prévios, os investigadores têm analisado qualitativamente os efeitos da oclusão tubular dos agentes anti-hiperestésicos pela observação das imagens em microscopia eletrônica de varredura, proporcionando apenas resultados descritivos ou por meio de simbologias ${ }^{3}$ ou, ainda, índices baseados em percentagens de túbulos ocluídos $^{104,114,221}$. Uma análise morfológica, para ser avaliada estatisticamente com maior precisão, necessita de dados numéricos complementares, menos subjetivos do que os obtidos por simples análise visual e conferência de escores, como a análise realizada nos testes preliminares ${ }^{208}$.

Dados menos subjetivos puderam ser agora obtidos por intermédio da digitalização das imagens de microscopia eletrônica de varredura, nas quais foram feitas medições através do programa de análise de imagem ImageLab, consagrando-se como um método de avaliação que proporciona total objetividade e maior credibilidade nos resultados. O método de análise computadorizada das imagens $^{221}$, fornecidas pela microscopia eletrônica de varredura, como fez 
também Ip et al. $^{102}$, em 1997, refinou a metodologia que envolve a análise das características superficiais da dentina tratada com agentes anti-hiperestésicos, fornecendo dados quantitativos de avaliação.

Outra observação interessante foi feita por Ling et al. $^{124}$, em 1997, quando observaram que os agentes anti-hiperestésicos previamente analisados como tendo efeito limitado ou pouco efeito na superfície dentinária proporcionaram redução significante na largura e área do túbulo quando analisados por meio da análise de imagens. Isso parece dar suporte às observações de Gillam et al. ${ }^{69}$, em 1997, de que apenas a análise descritiva ou qualitativa da superfície dentinária pode ser insuficiente para a avaliação das propriedades de oclusão tubular dos agentes anti-hiperestésicos.

\subsubsection{Microanálise de Raios $X$}

A microanálise de raios $X$ pode ser utilizada para caracterizar os elementos que compõem uma determinada amostra ${ }^{86,104,124}$. Baseia-se na captação de raios $X$ característicos, emitidos por determinada região da amostra após bombardeamento por um feixe de elétrons. Teoricamente, o bombardeamento da amostra por feixe de elétrons, entre outros fenômenos, produz o deslocamento de elétrons das camadas orbitais mais internas dos átomos que compõem a amostra. Os elétrons deslocados ou vacantes tendem a ser imediatamente substituídos por elétrons das camadas orbitais mais externas que, para tanto, liberam parte de sua energia característica na forma de raios X. A perda de energia em tais condições é característica particular de cada elemento de tal sorte que, o espectro ou os espectros de energia captados por detectores especiais, podem ser qualificadas e quantificadas por meio de programas de computador $^{20}$. Outros investigadores têm utilizado esse tipo de microscopia para avaliar a morfologia dentinária ou as características superficiais após a aplicação de agentes anti-hiperestésicos ${ }^{103,158,279,280,282,283}$. 
Há vários aspectos negativos relacionados com esse método de análise, principalmente no que se refere a erros de interpretação devido ao registro de elementos que não fazem parte da amostra ou pela baixa resolução entre elementos de peso atômico muito próximos, quando ocorre a sobreposição de picos de energia ${ }^{20}$. Ling et al. $^{124}$, em 1997, consideram, ainda, que a dificuldade de interpretação das microanálises de raios X pode ocorrer devido às falhas na detecção de componentes presentes em pequenas quantidades ou de agentes mascaradores.

A opção pelo uso desse método, no presente trabalho, apesar dos problemas mencionados e encontrados na prática, decorreu da oportunidade de melhor distinguir as interações dos agentes anti-hiperestésicos com o substrato dentinário, dando às observações um caráter menos objetivo ou especulativo.

\subsubsection{Difração de Raios $X$}

Segundo Le Geros ${ }^{121}$, os ensaios de difração de raios $X(X R D)$ já foram utilizados nos idos 1926 para a identificação da fase mineral do esmalte, dentina e osso humanos. Nos dias atuais, apesar do surgimento de técnicas sofisticadas para a análise das fases minerais dos dentes e ossos como as microscopias, ressonâncias e infravermelho, a difração raios $X$ continua sendo um dos métodos físicos mais conclusivos para a caracterização de fases cristalinas. Como no presente estudo, Tung et al. ${ }^{268}$, em 1993 e Suge et al. ${ }^{250}$, em 1999, também associaram os métodos de condutividade, microscopia eletrônica e difração de raios $X$ para estudar o poder obstrutivo de materiais quando em contato com a dentina.

Nesses ensaios, procurou-se seguir as mesmas estratégias empregadas nas outras fases desse experimento para a preparação das amostras, utilizando discos de dentina. Os pré-tratamentos da dentina foram realizados com a intenção de verificar se a condição do substrato, na presença da smear layer ou após sua remoção com EDTA, interfere com a 
composição dos cristais após a reação com os agentes anti-hiperestésicos. Outra curiosidade foi investigar se há variação na intensidade de precipitação cristalina e na composição dos cristais formados conforme o tempo de permanência do agente antihiperestésico em contato com o substrato dentinário, por 3 e 12 minutos.

Por outro lado, como fizeram Mongiorgi et al. ${ }^{141}$, em 1992, nesse estudo optou-se, também pela utilização de espécimes obtidos a partir de dentina pulverizada a fim de se investigar a composição das fases que caracterizam as reações dos agentes antihiperestésicos com a smear layer. Sabe-se, entretanto, que a utilização de pó de dentina ou de hidroxiapatita para simular a dentina normal está muito distante de replicar as reações que podem ocorrer sobre a dentina intacta em função da sua estrutura única. Quando se utiliza dentina pulverizada, há uma alta probabilidade de que o material colocado sobre as partículas se difundirá ao redor das mesmas e não reaja com elas. Já a dentina intacta tem uma enorme área de superfície interna disponível para reação com os materiais. Assim, pode-se teorizar que, para um disco de dentina com $1 \mathrm{~cm}^{2}$ de área de superfície e $1 \mathrm{~mm}$ de espessura, como empregados neste trabalho, ter-se-ia uma área interna de aproximadamente $94 \mathrm{~cm}^{2}$ disponível para reação. Assim, pode-se esperar que a dentina em pó seja menos efetiva do que a mesma espessura de dentina intacta ${ }^{159}$. 


\section{2 - Discussão dos Resultados}

\subsection{1 - Condutividade Hidráulica}

O modelo in vitro utilizado nesse estudo de condutividade hidráulica considera constantes todos os parâmetros da equação da Lei de Poiseuille-Hagen. Essa Lei determina as importantes variáveis que influenciam a filtração quais sejam a pressão hidrostática, raio dos túbulos dentinários, viscosidade do fluido e comprimento dos túbulos ou espessura dentinária. Nesses experimentos, algumas variáveis são inerentes ao próprio dente e não podem ser alteradas, como o tamanho e o número de túbulos dentinários ${ }^{156}$, a variabilidade regional da permeabilidade dentinária ${ }^{161}$ e a disposição dos túbulos. Outras variáveis podem ser controladas pelo pesquisador e têm sido corretamente padronizadas. Por exemplo, o disco de dentina deve ser removido da região central da dentina, o mais próximo possível da polpa $^{62}$, ser de pequena espessura ${ }^{255}$ e estar livre da smear layer ${ }^{190}$. Para a filtração podem ser utilizados a água ${ }^{73}$, solução salina ${ }^{89}$ ou soro eqüino de viscosidade conhecida. A área de exposição dentinária deve ser conhecida e a maior possíve $\left.\right|^{217}$ e o dente deve ser recémextraído ${ }^{36}$. Outro parâmetro de fundamental importância e que deve estar sob absoluto controle durante os testes é a pressão hidrostática de filtração. Como discutido anteriormente, a pressão ideal ainda não foi definida e tem-se encontrado na literatura valores variáveis sem qualquer justificativa e sem qualquer comparação com a pressão fisiológica do tecido pulpar ${ }^{37,108}$, que é de aproximadamente $14,1 \mathrm{~cm} \mathrm{H}_{2} \mathrm{O}$ em humanos ${ }^{42}$.

Dessa maneira, as variáveis que se mantiveram constantes durante todo o experimento são representadas pela área de superfície, espessura dos discos de dentina, pressão de filtração e a viscosidade do fluido. Apenas dois parâmetros variaram: o deslocamento de líquido, considerado a variável dependente, que se altera proporcionalmente ao raio dos túbulos, esta a variável independente ${ }^{81}$. Devido a essas variáveis biológicas dadas pela espessura do esmalte e altura dos cornos pulpares, cada 
disco, apesar de possuir $1 \mathrm{~mm}$ de espessura, é sempre diferente de qualquer outro disco. Segundo Greenhill e Pashley ${ }^{81}$, em 1981, isso introduz nos dados uma variabilidade biológica inerente quando analisados como um grupo. Para diminuir a variabilidade, os dados foram calculados como percentuais da condutividade hidráulica (Lp) máxima, onde cada disco é seu próprio controle. Assim, após calculados a média e o desvio padrão das mudanças percentuais de Lp, os dados percentuais foram submetidos à análise de variância a dois critérios e ao teste de Duncan, como utilizado em outros experimentos ${ }^{131,168,179,199,201,213,239,253}$.

$\mathrm{Na}$ literatura, a redução da permeabilidade dentinária in vitro, em termos de percentagem da condutividade hidráulica, proporcionada pelos agentes à base de oxalato de potássio, varia de $88,70 \%$ a $98,40 \%{ }^{61,63,81,161,180,181,184,286}$ e de 0 a $54 \%$ quando a dentina é tratada com fluoretos de sódio ${ }^{81,161,184,248 ;}$

Nesse experimento, os valores de fltração obtidos com os géis de oxalato de potássio nas cinco condições de pré-tratamento consideradas, variaram de $4,33 \%$ a $38,51 \%$, respectivamente, para o agente Experimental 2 sobre dentina molhada e o Oxa-Gel sobre dentina seca com ar (Tabelas 5 a 12). Esses valores representam índices de redução da condutividade hidráulica da ordem de 61,48\% a 95,66\% respectivamente, valores aproximados àqueles relatados na literatura. Para o fluoreto de sódio, os valores variaram de $41,47 \%$ a $77,47 \%$, respectivamente, para as condições da dentina acidificada e seca com ar e seca com papel.

É importante mais uma vez salientar que os valores de condutividade hidráulica, principalmente os obtidos após a aplicação dos materiais, podem fornecer conclusões equivocadas se interpretados isoladamente. Como o objetivo do tratamento com os agentes anti-hiperestésicos é reduzir a filtração a valores que se equiparem aos $10 \%$ a $20 \%$ daqueles obtidos na presença da smear layer ${ }^{174,186,217}$, a proximidade a esses valores pode ser considerada um bom parâmetro de análise do poder obstrutivo dos materiais anti- 
hiperestésicos. Assim, na Tabela 9, os valores de filtração dos materiais, expressos em valores percentuais da permeabilidade máxima, foram comparados aos valores de filtração na presença da smear layer e após o desafio ácido. De uma maneira geral, pôde-se verificar que quando os valores de condutividade obtidos após o tratamento com os materiais experimentais estão próximos aos valores de filtração na presença da smear layer, mais distantes estavam dos valores após o desafio ácido e vice-versa. A observação das diferenças entre esses valores permite uma visão aproximada entre a ação dos agentes anti-hiperestésicos, comparativamente ao efeito da smear layer e ao desafio ácido, aproximando-se de uma condição clínica em que a smear layer proporciona proteção natural da dentina exposta e o desafio ácido, às variações do $\mathrm{pH}$ bucal e seu possível papel na degradação das estruturas mineralizadas e no estímulo da hiperestesia.

A comparação entre os valores de filtração na presença da smear layer e após o tratamento com os agentes anti-hiperestésicos nos permite verificar claramente, por meio das Tabelas 9 e 16, que os agentes derivados do oxalato de potássio e o fluoreto de sódio mais se aproximam da filtração mínima quando aplicados sobre a dentina lavada e seca com ar, lavada e seca com papel ou mantida molhada e fornecem, invariavelmente, valores de filtração mais discrepantes em relação à smear layer quando a acidez da dentina é promovida pela permanência do EDTA previamente ao tratamento.

Ao contrário do esperado, a dentina acidificada não se tornou mais reativa aos agentes anti-hiperestésicos estudados. No caso dos derivados do oxalato de potássio, podese sugerir que a dentina excessivamente acidificada não garante a disponibilidade de íons cálcio e fosfato, suficientes para intensificar a deposição de precipitados de oxalato de cálcio na superfície da dentina e no interior dos canalículos dentinários, a ponto de reduzir a permeabilidade da dentina. Outra hipótese para essa maior permeabilidade seria a formação de uma barreira à penetração do oxalato de potássio pela deposição dos produtos da dissolução da dentina, oriundos do condicionamento ácido prévio e que, por não terem sido 
subseqüentemente lavados, permaneceram na superfície. Por conseqüência, a precipitação cristalina produzida pela subseqüente aplicação dos géis de oxalato de potássio pode ter se concentrado mais na superfície do que no interior dos túbulos, como sugere a Figura 40, proporcionando menor resistência à filtração do líquido e maior facilidade de deslocamento dos cristais da superfície da dentina.

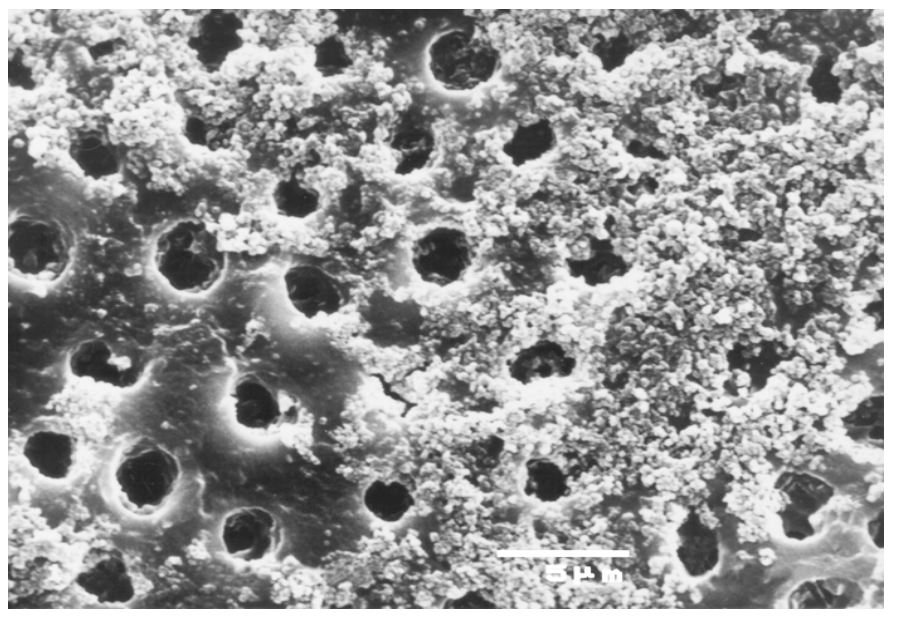

Figura 40 - Dentina acidificada com EDTA e não lavada, previamente à aplicação do oxalato de potássio. Percebese 0 aspecto granuloso da superfície, sugerindo a permanência dos produtos da dissolução da dentina pelo ácido.

Há outras duas possíveis razões para que não se tenham obtido os resultados positivos nos níveis esperados com a acidificação prévia da dentina. Em primeiro lugar, a acidificação da dentina ocorreu concomitantemente com a dissolução da smear layer e durante o tempo de ação do EDTA procedeu-se as quatro medições da filtração. Isso pode ter provocado o deslocamento rápido, pela pressão de filtração, dos produtos da reação da smear layer com o ácido, exaurindo os íons reativos com os materiais experimentais de modo geral, e particularmente daqueles à base de oxalato de potássio. Outra hipótese está relacionada com as características de desmineralização com EDTA, já que esse remove íons da dentina por quelação do cálcio em pH neutro, não disponibilizando rapidamente esse elemento para combinação com os agentes estudados.

O mesmo pode ter ocorrido nos espécimes tratados com o Gel Fluoretado, porém em maiores proporções. Pode-se observar que os valores de filtração obtidos imediatamente após o tratamento com o Gel Fluoretado variaram de 41,47\% a 77,47\%, e 
foram tanto mais altos quanto mais úmida ou acidificada foi a dentina, e significativamente maiores que os de suas respectivas smear layers. Pode-se adicionar ainda que, sendo muito instável, os cristais de fluoreto de cálcio eventualmente precipitados na superfície dos espécimes, tenham sido rapidamente dissolvido no ambiente aquoso da dentina úmida ou molhada. Essa condição está, provavelmente, relacionada com a curta duração do efeito anti-hiperestésico obtido com os produtos à base de fluoreto de sódio, como relatado por outros autores $^{4,60,203,265}$.

Clinicamente, o tratamento da hiperestesia dentinária por meio de agentes que promovem a obstrução dos túbulos dentinários tem a intenção de promover a precipitação de cristais que reduzam a movimentação do fluido pulpodentinário e, ao mesmo tempo, resistam ao poder de dissolução próprio de eventos ácidos recorrentes no meio bucal. Assim, nos testes in vitro de condutividade hidráulica da dentina, o desafio ácido é incluído com a intenção de experimentar a resistência dos depósitos cristalinos à solubilidade e, de certa forma, a longevidade do efeito obstrutivo. Por esse raciocínio, quanto mais próximos entre si forem os valores de filtração da dentina obtidos depois do tratamento e depois do desafio ácido, teoricamente mais durável será o efeito obstrutivo. A exata idéia dessa relação é dada na Tabela 11, onde se constata, de fato, que os valores de filtração após o desafio variam desuniformemente, mas mostram sua tendência de se aproximarem dos valores da filtração obtidos com o tratamento, conforme esses sejam mais elevados. Essa tendência pode ser explicada pelo fato de que naquelas situações em que os valores de filtração tenham sido inicialmente mais elevados (menor precipitação de cristais) o desafio ácido tem menores depósitos cristalinos com que reagir.

As Tabelas 20 e 21 foram desenvolvidas para auxiliar a visualização da ordenação dos melhores resultados dos materiais e das condições de pré-tratamento de forma independente, tendo como referência as diferenças com a smear layer e com o condicionamento ácido. Mostram, então, que o agente Experimental 2 foi o que melhor 
resistiu à pressão da filtração, seguido do Oxa-Gel, do Experimental 1 e do Gel Fluoretado. Quando se considera a comparação com os valores após o desafio ácido, a menor diferença foi observada para o Experimental 2, seguido pelo Experimental 1, Gel Fluoretado e OxaGel. Convém salientar, como já mencionado anteriormente, que a colocação do Gel Fluoretado numa posição de melhor desempenho que o Oxa-Gel, após o desafio ácido, não garante ao primeiro a condição de maior resistência à dissolução, mas simplesmente que há menos substrato para ser atacado pelo ácido.

Tabela 20 - A- Ordenação dos materiais experimentais, do melhor para o pior, em função das diferenças de filtração comparativamente a smear layer e ao desafio ácido.

B - Ordenação das condições de pré-tratamento, da melhor para a pior, em função das diferenças de filtração comparativamente a smear layer e ao desafio ácido.

\begin{tabular}{|c|c|c|c|}
\hline \multicolumn{2}{|c|}{ A - Material Experimental } & \multicolumn{2}{|c|}{ B - Pré-tratamento } \\
\hline $\begin{array}{l}\text { Smear Layer } \\
\text { e Material }\end{array}$ & $\begin{array}{c}\text { Material e } \\
\text { Desafio Ácido }\end{array}$ & $\begin{array}{l}\text { Smear Layer } \\
\text { e Material }\end{array}$ & $\begin{array}{c}\text { Material e } \\
\text { Desafio Ácido }\end{array}$ \\
\hline Experimental 2 & Experimental 2 & seca com ar & molhada \\
\hline Oxa-Gel & Experimental 1 & seca com papel & $\begin{array}{l}\text { acidificada e } \\
\text { seca com papel }\end{array}$ \\
\hline Experimental 1 & Gel Fluoretado & Molhada & $\begin{array}{l}\text { acidificada e } \\
\text { seca com ar }\end{array}$ \\
\hline \multirow[t]{2}{*}{ Gel Fluoretado } & Oxa-Gel & $\begin{array}{l}\text { acidificada e } \\
\text { seca com ar }\end{array}$ & seca com pape \\
\hline & & $\begin{array}{l}\text { acidificada e } \\
\text { seca com papel }\end{array}$ & seca com ar \\
\hline
\end{tabular}

A modificação da hidratação da dentina foi considerada como uma das variáveis que possivelmente afetam a reação para a formação dos precipitados, como aparece na Tabela 21, mostrando as diferenças dos resultados frente às variações na umidade dentinária. A ausência do fluido dentinário nas amostras de dentes extraídos pode influir nas características dos precipitados quando comparados com os formados pela reação com a dentina in vivo ${ }^{56}$. Conforme os comentários de Hodgkinson ${ }^{92}$, em 1977, e de Dragolich, Pashley e Brennan ${ }^{56}$, em 1993, a hidratação da dentina reflete no tipo de cristal de oxalato de cálcio que se forma, sendo o trihidratado mais instável e solúvel do que ao di-hidratado e 
o mono-hidratado. As micrografias representadas na Figura 41 mostram que os cristais formados pelos agentes à base de oxalato de potássio experimentados na dentina seca com ar apresentam forma tetragonal ou octogonal, compatível com a forma di-hidradata de precipitação $^{56}$. O entendimento de que variações nas condições de umidade e acidez pudessem, então, interferir no padrão de reação do oxalato de potássio com o substrato dentinário, constituiu um grupo de variáveis desse trabalho. Os resultados de filtração mostram, de fato, que a dentina seca com ar é passível de reação com o oxalato de potássio, levando à precipitação de cristais de oxalato de cálcio di-hidratados, condição que pode ser aplicada clinicamente.

Tabela 21 - Seqüência dos materiais frente às condições de pré-tratamento que produziram as menores diferenças, em ordem crescente, entre os parâmetros A - smear layer e material e, também, B - material e desafio ácido.

\section{A - Smear Layer - Material}

1. Oxa-Gel, seca com papel

2. Oxa-Gel, seca com ar

3. Experimental 1, seca com ar

4. Experimental 2, seca com ar

5. Experimental 2, molhada

6. Experimental 2, seca com papel

7. Experimental 1, molhada

8. Experimental 2, acidificada e seca com papel

9. Experimental 2, acidificada e seca com ar

10. Oxa-Gel, molhada

11. Experimental 1, seca com papel

12. Experimental 1, acidificada e seca com papel

13. Oxa-Gel, acidificada e seca com ar

14. Experimental 1, acidificada e seca com ar

15. Oxa-Gel, acidificada e seca com papel

16. Flúor, seca com ar

17. Flúor, seca com papel

18. Flúor, acidificada e seca com ar

19. Flúor, molhada

20. Flúor, acidificada e seca com papel
B - Material - Desafio Ácido

1. Flúor, acidificada e seca com ar

2. Oxa-Gel, acidificada e seca com papel

3. Experimental 1, acidificada e seca com papel

4. Oxa-Gel, molhada

5. Experimental 2, molhada

6. Experimental 1, molhada

7. Experimental 2, acidificada e seca com papel

8. Flúor, molhada

9. Experimental 2, seca com papel

10. Experimental 2, seca com ar

11. Experimental 1, seca com ar

12. Oxa-Gel, acidificada e seca com ar

13. Experimental 1, seca com papel

14. Flúor, seca com papel

15. Flúor, seca com ar

16. Flúor, acidificada e seca com papel

17. Experimental 2, acidificada e seca com ar

18. Oxa-Gel, seca com papel

19. Experimental 1, acidificada e seca com ar

20. Oxa-Gel, seca com ar 

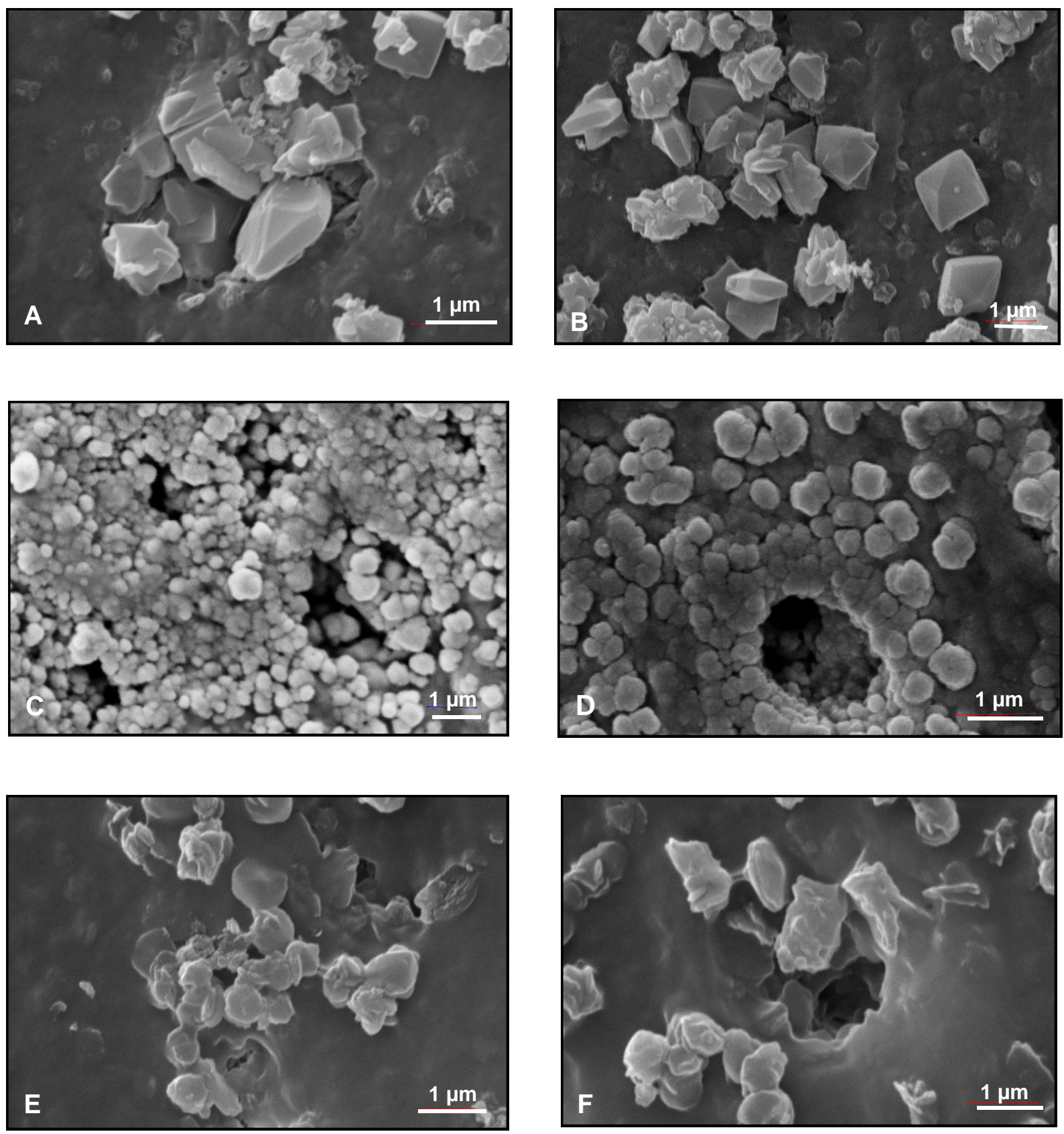

Figura 41 - Precipitações cristalinas derivadas da reação dos géis à base de oxalato de com o substrato dentinário: A e B - cristais com formato romboédrico e contorno definido são formados pela reação do material Oxa-Gel com a dentina; C e D-percebe-se a forma mais globular dos cristais formados pelo material Experimental 1; E e F - precipitação característica do material Experimental 2, mostrando cristais romboédricos envoltos por estruturas semelhantes a resíduos do gel. 
Os resultados desse estudo podem ser comparados aos da literatura, apesar de apresentarem diferenças na metodologia principalmente quanto à concentração dos agentes anti-hiperestésicos experimentados, à pressão hidrostática, ao líquido filtrado através da dentina, e à presença ou não da smear layer previamente à aplicação dos materiais. Além disso, nenhum dos estudos relata sobre a condição de umidade da dentina sobre a qual foram aplicados os agentes. Quanto à acidificação, todos os experimentos levantados procedem a remoção do ácido por lavagem previamente ao tratamento com os agentes antihiperestésicos.

De uma maneira geral, com base nos dados da literatura, os agentes derivados do oxalato de potássio atuam reduzindo o fluxo de fluido em proporções similares, comparativamente à permeabilidade máxima. Aparentemente, um dos fatores de discrepância entre os valores apareceu quando se dá a variação entre a remoção ou não da smear layer previamente à aplicação dos materiais. Pashley e Galloway ${ }^{181}$, em 1985, por exemplo, não efetuaram o condicionamento ácido prévio para a remoção da smear layer, e encontraram valores de filtração de $26 \%$, $23 \%$ e $12 \%$, respectivamente, para o tratamento com os oxalatos de potássio a $30 \%$ e a $3 \%$ ou com a combinação de ambos. Valores igualmente maiores de filtração, após o tratamento com oxalato de potássio a 3\%, foram obtidos por Fogel e Pashley ${ }^{61,63}$, em 1990, e em 1993, permitindo a passagem de $11,30 \%$ a $38,70 \%$ de líquido. Entretanto, os experimentos foram realizados, respectivamente, em dentina radicular interna e externa e utilizando uma pressão hidrostática mais elevada. Esses valores foram elevados em relação aos valores obtidos por outros autores que removeram a smear layer antes de tratar a dentina, obtendo índices de filtração variando de $1,6 \%$ a $8 \%{ }^{81,161,180,184,248}$.

A filtração após o tratamento com oxalato de potássio a $30 \%$ apresentada por Greenhill e Pashley ${ }^{81}$, em 1981, na dentina isenta da smear layer, foi de 1,60\%. Pashley e Depew $^{180}$, em 1986, com a oxalato de potássio a 3\%, conseguiram uma filtração de 1,75\%. 
Em 1984, Pashley et al. ${ }^{168}$ obtiveram $4,29 \%$ com o oxalato de potássio a $2 \%$ e Pashley, Leibach e Hornert ${ }^{184}$, em 1987, filtraram $4 \%$ de líquido após os tratamento da dentina com o oxalato de potássio a $3 \%$. Mongiorgi et al. $^{141}$, em 1992, para três formulações à base de oxalato de potássio, obtiveram valores de filtração entre 2,2\% a 3,9\%. Mongiorgi e Prati ${ }^{144}$, em 1994, obtiveram 3,9\% de filtração para o oxalato de monopotássio mono-hidratado a $3 \%, 3,5 \%$ para o oxalato dipotássio a $30 \%$ e $2,2 \%$, para a combinação das formulações. $\mathrm{Na}$ atual pesquisa, o valor mais baixo de filtração foi de $4,33 \%$, com a dentina mantida molhada e tratada com o agente Experimental 2, à base de oxalato de potássio mono-hidratado a $3 \%$.

Santiago ${ }^{227}$, em 1999, utilizando metodologia muito semelhante à utilizada no presente estudo, aplicando formulações à base de oxalato de potássio na dentina seca com papel, alcançou valores de filtração variando entre $21,76 \%$ e $29,71 \%$. No presente estudo, a média dos valores para a mesma condição de pré-tratamento da dentina variou entre $14,47 \%$ e $18,71 \%$, respectivamente para os mesmos materiais.

$\mathrm{Na}$ literatura, os estudos que obtiveram melhores resultados foram os que utilizaram o ácido cítrico para a remoção da smear layer, previamente ao tratamento com os derivados do oxalato de potássio ${ }^{81,168,180,184}$. No presente estudo, assim como no experimento realizado por Santiago ${ }^{227}$, em 1999, a remoção da smear layer foi realizada com EDTA, por ter ação mais branda do que o ácido cítrico, evitando a excessiva desmineralização da dentina intertubular e a destruição da dentina peritubular (Figura 39). Entretanto, a smear layer pode não ter sido suficientemente removida, dificultando a penetração do oxalato de potássio para a reação de precipitação dos cristais de oxalato de cálcio no interior dos túbulos (Figura 38). Essa suposição pode ser reforçada pelos achados de Shono et al. ${ }^{237}$, em 1994, que após examinarem microscopicamente espécimes fraturados, relataram não encontrar cristais muito profundamente no interior dos túbulos após o tratamento da smear layer com uma 
solução de oxalato de potássio, ao contrário do observado quando a smear layer foi removida.

Os trabalhos que estudaram o comportamento dos fluoretos nos ensaios de condutividade hidráulica invariavelmente obtiveram resultados inferiores quando comparados aos valores obtidos com o oxalato de potássio ${ }^{81,168,184}$. Greenhill e Pashley ${ }^{81}$, em 1981, obtiveram valores de filtração de $67 \%$ a $92,33 \%$ após a atuação do fluoreto de sódio a $1,23 \%$ e a $2 \%$, variando ainda a acidez e a forma de aplicação. Pashley et al. ${ }^{168}$, em 1984, com o fluoreto de sódio a 0,2\% puro, obtiveram $98,09 \%$ de filtração de líquido através da dentina. Quando foi aplicado na forma de dentifrícios, em três diferentes diluições, o fluoreto de sódio apresentou valores de filtração que variaram entre $43,03 \%$ e $52,45 \%$. Pashley, Leibach e Hornert ${ }^{184}$, em 1987, utilizando uma mistura de fluoreto de sódio com glicerina e Kaolin, mediram valores de $32,70 \%$ a $46 \%$ de filtração. Assim, os resultados obtidos nesse estudo podem ser comparados àqueles encontrados na literatura ${ }^{81,168,184}$, já que o melhor resultado de filtração obtido para o Gel Fluoretado foi $41,47 \%$ para a dentina seca com ar, alcançando $77,47 \%$ quando a dentina foi previamente acidificada.

A ação anti-hiperestésica dos compostos fluoretados não está bem clara quando se analisam os resultados encontrados na literatura, seja do ponto de vista de estudos clínicos $^{70,263,272}$, in vivo ou de pesquisas laboratoriais ${ }^{81,168}$, in vitro. Os resultados do presente estudo mostram que o fluorfosfato acidulado a $1,23 \%$ promove redução da filtração da dentina de cerca de $22 \%$ a $58 \%$, independentemente da condição de pré-tratamento da superfície dos espécimes. Esses valores, se associados aos resultados clínicos relatados por outros autores, podem corresponder ao potencial anti-hiperestésico relativo desse material. Entretanto, seja qual for o mecanismo de ação, o flúor não demonstra o mesmo padrão obstrutivo dos derivados do oxalato de potássio, uma vez que não se observam depósitos cristalinos na superfície da dentina, e apenas escassas precipitações no interior 
dos túbulos foram percebidas quando os espécimes foram analisados por microscopia eletrônica de varredura. É possível que a redução da filtração conseguida com o Gel Fluoretado no presente trabalho, ainda que de baixas proporções, se deva à penetração do gel e parcial obstrução dos túbulos dentinários (Figura 41).

\subsubsection{Microscopia Eletrônica de Varredura}

Os valores de condutividade hidráulica confrontados com a capacidade obstrutiva dos géis experimentais mostrados em microscopia eletrônica encontram-se dispostos na Tabela 22, para maior facilidade de compreensão. Esses dados são exclusivos da dentina seca com ar, considerada a condição que permitiu melhores resultados de filtração, independentemente do material estudado e, portanto, a escolhida para o estudo em microscopia eletrônica de varredura. Nota-se uma certa coerência entre os valores de condutividade hidráulica e os de microscopia eletrônica de varredura, exceto para o grupo do Gel Fluoretado, na seqüência de experimentos: smear layer, material e desafio ácido (Tabela 22). Há, entretanto, uma diferença que precisa ser destacada entre os valores de condutividade e o cálculo das áreas desobstruídas evidenciadas em microscopia eletrônica. Pelas imagens vistas microscopicamente (Figuras 34-37A) o efeito obstrutivo da smear layer é completo enquanto seus valores de condutividade hidráulica variam de $12,4 \%$ a $17,8 \%$. Isso mostra que, embora notavelmente presente, a smear layer não se fixa à dentina e no interior dos túbulos com a força suficiente para barrar o deslocamento de líquido durante a filtração (Gráfico 13). Quando se compara, pelo mesmo raciocínio, o efeito dos materiais em ambos os ensaios (de filtração e de MEV), observa-se que ambos os valores são bem próximos para os materiais à base de oxalato de potássio, o que não acontece com o Gel Fluoretado. Neste, a percentagem de filtração $(41,47 \%)$ é o dobro do percentual de área não obstruída (20,19\%), mostrando que, à semelhança do que acontece com a smear layer, a obstrução demonstrada visualmente não garante um estado de impermeabilização da dentina. A concentração de resíduos no interior dos túbulos foi insuficiente para resistir à 
pressão de filtração, que é um teste dinâmico, ao contrário da natureza estática das imagens de microscopia eletrônica de varredura (Gráfico 13). Por outro lado, os géis de oxalato de potássio mostraram que os depósitos cristalinos na embocadura e, provavelmente no interior dos túbulos dentinários, são mais resistentes à pressão hidrostática de filtração, o que se demonstra pela semelhança dos resultados para ambos os critérios de avaliação.

Tabela 22 - Comparação entre as médias percentuais obtidas após a aplicação dos materiais na dentina seca com ar, conforme a seqüência experimental, analisadas por meio dos ensaios em microscopia eletrônica de varredura e de condutividade hidráulica.

\begin{tabular}{|c|c|c|c|c|c|}
\hline & & Oxa-Gel & Experimental 1 & Experimental 2 & Gel Fluoretado \\
\hline \multirow{2}{*}{ Smear Layer } & Filtração & 17,04 & 17,85 & 15,14 & 12,49 \\
\hline & MEV & 08,78 & 03,20 & 02,17 & 02,37 \\
\hline \multirow{2}{*}{ Material } & Filtração & 10,59 & 14,53 & 12,35 & 41,47 \\
\hline & MEV & 15,64 & 14,03 & 19,34 & 20,19 \\
\hline \multirow{2}{*}{ Desafio Ácido } & Filtração & 34,89 & 19,25 & 16,55 & 49,65 \\
\hline & MEV & 20,82 & 21,70 & 25,38 & 42,01 \\
\hline
\end{tabular}

Quando se considera o desafio ácido, alguma variação é observada dos resultados de filtração para as imagens de microscopia eletrônica de varredura. Parece que, nesse caso, o eventual conteúdo intratubular produzido pelo Oxa-Gel e pelo Gel Fluoretado é mais facilmente deslocado pela pressão de filtração, já que os valores de filtração para esses materiais $(34,8 \%$ e $49,6 \%)$ são maiores que os respectivos percentuais de área desobstruída (20,8\% e 42,0\%). Os géis experimentais 1 e 2 apresentaram desempenho inverso, mostrando áreas proporcionais desobstruídas maiores que seus percentuais de filtração. Isso pode significar que, apesar de pouco resistentes ao condicionamento superficial, visualmente esses géis mantêm depósitos cristalinos no interior dos túbulos, mais resistentes à dissolução pelo ácido cítrico. 
Gráfico 13 - Comparação entre as médias percentuais obtidas conforme a seqüência experimental, independentemente do material utilizado na dentina seca com ar, por meio dos ensaios em microscopia eletrônica de varredura e de condutividade hidráulica. (representação gráfica das Tabelas 10 e 14)

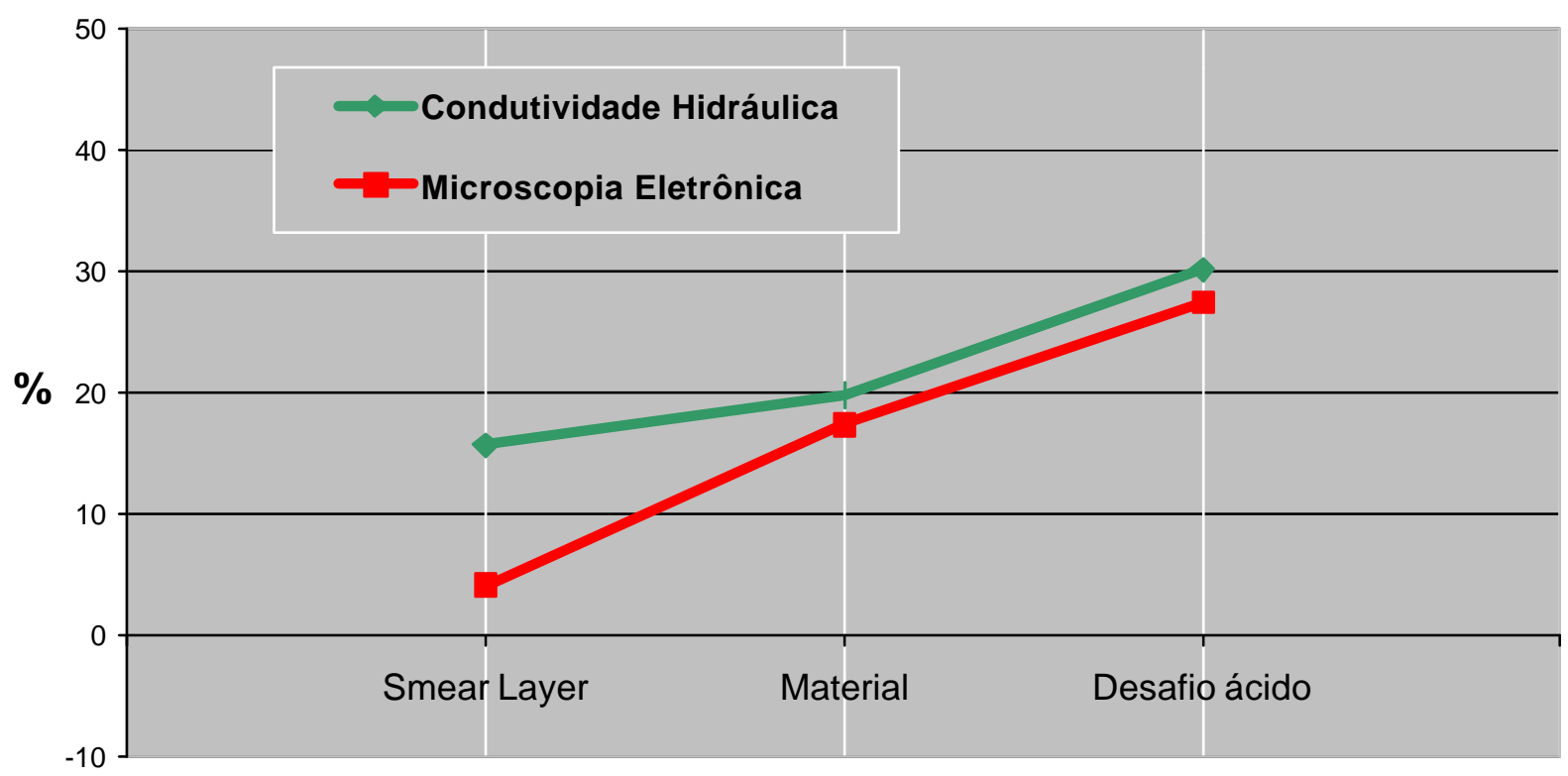

Agentes Anti-Hiperestésicos

Com relação ao mecanismo de ação, acredita-se que quando o oxalato acidificado é aplicado na superfície dentinária, penetra até a subsuperfície imediata da dentina, que está livre de cálcio e fosfato devido ao tratamento ácido prévio, interferindo na penetração do ácido oxálico. O trajeto do ácido oxálico através dos túbulos dentinários segue até que o ácido encontre e reaja com a dentina mineralizada, isto é, dentina que contenha fosfato de cálcio, freqüentemente de 3 a $15 \mu \mathrm{m}$ abaixo da superfície dentinária. Nesse local de subsuperfície, o oxalato acidificado dissolve cálcio e forma cristais de oxalato de cálcio subsuperficiais. Como o oxalato acidificado penetra além da superfície dentinária, cristais maiores de oxalato de cálcio são formados quanto mais o ácido oxálico encontra o cálcio. 0 crescimento cristalino em muitos casos pode quase completamente ocluir o lúmen dos túbulos, iniciando-se 5-8 $\mu \mathrm{m}$ abaixo da superfície dentinária e estendendo-se a aproximadamente 15-20 $\mu \mathrm{m}$. A dentina, então, torna-se substancialmente impermeável ao movimento do fluido através dos túbulos preenchidos com oxalato de cálcio. Entretanto, apesar do oxalato de cálcio ser relativamente insolúvel, pois sua solubilidade é tão baixa 
quanto $0,58 \mathrm{mg}$ em 100 gramas $^{248}$, a dentina não permanece impermeável indefinidamente, devido aos efeitos de dissolução provocados pela saliva e estímulos mecânicos do meio oral, provocando a perda da oclusão tubular pelos cristais.

A reação do oxalato de potássio a $3 \%, \mathrm{pH} 2$ com a dentina foi analisada microscopicamente por vários autores. Dentre eles estão Pashley, Leibach e Horner ${ }^{168}$, em 1987; por Fogel e Pashley ${ }^{61,63}$, em 1990 e em 1991; Knight et al. ${ }^{114}$, em 1993; Haveman e Charlton ${ }^{88}$, em 1994; Mordan, Barber e Gillan ${ }^{146}$, em 1997; Ling et al. ${ }^{124}$, em 1997. Outros como Greenhill e Pashley ${ }^{81}$, em 1981; Pashley e Galloway ${ }^{181}$, em 1985; Mongiorgi et al. ${ }^{142,143}$, em 1991, analisaram também o oxalato de potássio a $30 \%$.

Quando empregaram o oxalato de potássio a 3\% na dentina, os autores encontraram depósitos cristalinos na superfície e dentro dos túbulos dentinários. Mordan, Barber e Gillan ${ }^{146}$, em 1997, entretanto, relataram que encontraram depósitos cristalinos na superfície e dentro dos túbulos dentinários apenas após várias aplicações de oxalato. Nos experimentos realizados em dentina radicular por Fogel e Pashley ${ }^{63}$, em 1990, o oxalato de potássio $3 \%$ cobriu completamente a superfície com um fino precipitado cristalino. Mongiorgi et al. ${ }^{142,143}$, em 1991 e em 1992, utilizando oxalato de potássio a $30 \%$ e a 3\%, respectivamente, descreveram cristais irregulares recobrindo a superfície dentinária e ocluindo parcialmente os túbulos, enquanto Mongiorgi e Prati ${ }^{144}$, em 1994, relataram que as soluções a $3 \%$ e a $30 \%$, e ainda a combinação de ambas, cobrem a dentina com uma espessa camada de precipitados cristalinos.

Como o tamanho das embocaduras dos túbulos dentinários na dentina exposta varia de quase totalmente obstruídos a amplamente abertos ${ }^{283}$, uma das variáveis críticas na determinação da falha ou do sucesso do potencial dos agentes anti-hiperestésicos é o tamanho dos cristais relativamente ao tamanho dos túbulos dentinários ${ }^{81}$. Greenhill e Pashley $^{81}$, em 1981, trabalhando com o oxalato de potássio a $30 \%$, mostraram que o tamanho dos cristais formados tem aproximadamente as mesmas dimensões das aberturas 
tubulares e que, eventualmente, aparecem estruturas semelhantes a uma teia, conectando o cristal às paredes dos túbulos. A visualização em microscopia eletrônica revelou um precipitado moderadamente denso e homogêneo cobrindo a superfície dentinária, fechando as aberturas tubulares e penetrando para o interior dos túbulos. Apesar dos cristais normalmente não penetrarem mais do que a porção afunilada dos túbulos, ocluíram uma grande parte do seu diâmetro, reduzindo o diâmetro funcional. Acredita-se que os cristais que penetram para o interior dos túbulos dentinários reduzam mais a $\mathrm{Lp}$ do que os precipitados superficiais. Entretanto, a capacidade de obstruir a embocadura dos túbulos pode ter efeito definitivo na redução da Lp, mesmo que não ocorra precipitação de cristais profundamente no interior dos mesmos. Evidentemente, a combinação das duas possibilidades pode significar a otimização do poder obstrutivo dos depósitos cristalinos. Assim, um dos aspectos de maior importância no estudo da Lp e dos depósitos cristalinos é a consideração do tamanho médio dos cristais formados com relação ao diâmetro dos túbulos dentinários. No presente trabalho, o tamanho médio dos cristais foi em torno de 0,5 $\mu \mathrm{m}$ para um diâmetro tubular médio de 1,56 $\mu \mathrm{m}$, aproximadamente.

O fator principal de influência no tamanho dos cristais a serem formados é a concentração dos reagentes ou a combinação da concentração e pH. Fogel e Pashley ${ }^{63}$, em 1990, relataram que o tratamento da dentina radicular mais interna com oxalato potássio a $3 \%$ foi mais efetivo do que na dentina mais externa, pois a primeira possui túbulos levemente mais amplos que mais se aproximam do tamanho dos cristais de oxalato de cálcio. Para Pashley e Galloway ${ }^{181}$, em 1985, o tratamento da smear layer com oxalato de potássio a $30 \%$, leva à formação de cristais maiores, de 1 a $5 \mu \mathrm{m}$, sendo que o desafio com ácido cítrico leva à dissolução da smear layer homogênea e amorfa ao redor dos cristais que permanecem ocluindo os túbulos. Quando a concentração do oxalato é reduzida para 3\%, o precipitado se torna menos granuloso, e aparentemente não se modifica após o desafio ácido. Quando a smear layer é tratada com a combinação dos oxalatos de potássio a 3\% e a $30 \%$, a superfície fica densamente coberta por uma mistura heterogênea de cristais, 
ocorrendo uma leve mudança após o desafio ácido. Os menores cristais são formados pelo oxalato de potássio a 3\%, que provavelmente, por ser mais ácido, ioniza maior quantidade de íons cálcio e fosfato e forma uma mistura de cristais de fosfato de cálcio e de oxalato de cálcio.

No trabalho ora em discussão, as concentrações das soluções de oxalato de potássio eram bastante semelhantes entre si, variando de $3 \%$ para $6 \%$. Em decorrência disso, os cristais formados eram de tamanhos reduzidos viabilizando a obstrução da embocadura dos túbulos dentinários e, eventualmente, facilitando a precipitação ao longo das formações tubulares. Como relatado em Resultados, a formação de cristais no interior dos túbulos se deu em profundidades semelhantes para os agentes à base de oxalato de potássio. As variações do $\mathrm{pH}$ desses agentes não parecem produzir diferenças significantes nas características de deposição e forma dos cristais. Apenas o material Experimental 2, com $\mathrm{pH} 2$, mostrou formações cristalinas ligeiramente menores e mais regulares, com aspecto romboédrico, unidos entre si por estruturas que se assemelham a resíduos do gel (Figura 41).

Quanto ao $\mathrm{pH}$ das soluções, Pashley ${ }^{181}$ sugere que uma solução mais próxima da neutralidade, como o oxalato de potássio a $30 \%$, reage com o cálcio ionizado do fluido dentinário ${ }^{43}$, sendo que o grau de produção dos cristais é baixa devido à limitada concentração de cálcio ionizado. Em contraste, o oxalato de potássio a 3\% reage como um condicionador ácido moderado, aumentando o grau de cálcio ionizado que resulta numa formação acelerada de cristais ${ }^{150,181}$. De fato Knight et al. ${ }^{114}$, em 1993, observaram após aplicarem o oxalato de potássio a $3 \%$ em dentina que os cristais tendem à deslocação com spray de água por um minuto. Em outra investigação, a associação dos oxalatos de potássio a $3 \%$ e a $30 \%$ exibe uma densa cobertura com cristais, cuja quantidade diminuiu após sete dias em contato com a saliva em ambiente bucal ${ }^{112}$. A ação solubilizadora da saliva foi confirmada por Suge et al. ${ }^{248}$, em 1995, quando verificaram que os valores de filtração da 
dentina tratada com oxalato de potássio aumentaram de $8 \%$ para $39 \%$, depois de sete dias de imersão em saliva.

Os espécimes tratados com Gel Fluoretado no presente trabalho não mostraram deposições cristalinas na superfície, apenas escassas deposições no interior dos túbulos foram observadas (Figura 42). As micrografias dos espécimes desse grupo revelaram que as embocaduras dos túbulos, quando obstruídas, apresentavam uma massa amorfa sugerindo resíduos do gel, não compatível com a morfologia cristalina. Provavelmente, os cristais formados na superfície dentinária são mais suscetíveis a lavagem do material após o tratamento. A mesma dificuldade em encontrar partículas depositadas nos espécimes tratados com fluoreto de sódio foi reportada por Knigth et al. ${ }^{114}$, em 1993.
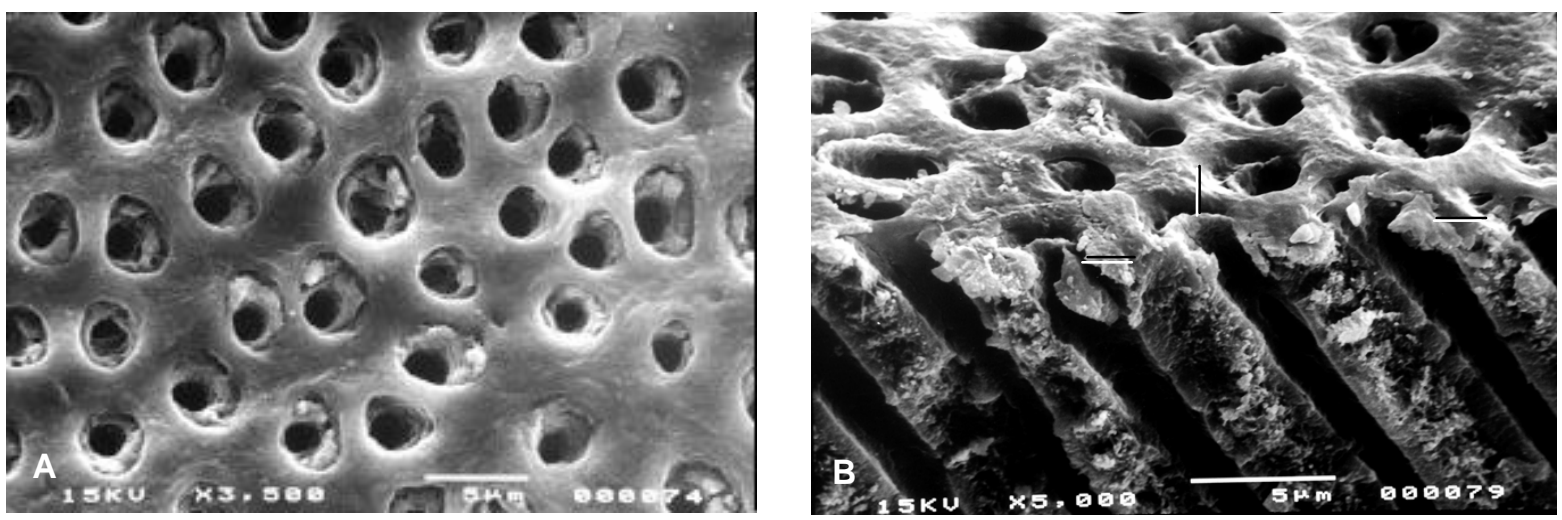

Figura 42 - Aparência da dentina tratada com o Gel Fluoretado: A - superfície dentinária e as aberturas tubulares livres de cristais, mostrando um massa amorfa circundando as embocaduras; $\mathbf{B}$ - massa amorfa aderida às paredes dos túbulos fraturados, na região próxima à embocadura, sugerindo resíduos do material.

Contrariamente, Lukomsky ${ }^{127}$, em 1941, encontrou precipitações granulares em dentes tratados clinicamente com fluoreto de sódio e extraídos a diferentes intervalos, atribuindo a essas formações o efeito anti-hiperestésico conseguido. Também, Zaimoglu e Aydin ${ }^{285}$, em 1992, revelaram a presença de precipitados arredondados formando densos smear plugs quando observados em microscopia eletrônica de varredura. 
Nesse trabalho, a confrontação dos resultados de filtração com os de microscopia eletrônica de varredura mostram que o tênue efeito do Gel Fluoretado na redução da condutividade hidráulica da dentina não tem correspondência com as imagens de microscopia eletrônica, do ponto de vista da deposição de cristais. Como sugerido por Pashley ${ }^{164}$, em 1986, provavelmente, o tamanho reduzido dos cristais de fluoreto de sódio que, quando formados, se aproximam de $0,05 \mu \mathrm{m}$, não tenha efeito consistente para reduzir a filtração da dentina nos mesmos patamares do oxalato de potássio. Essas observações são consonantes com os resultados observados no presente trabalho, onde os cristais, quando presentes, não representavam uma real obstrução mecânica dos túbulos dentinários. Supõe-se que, por essa razão, os cristais penetraram em média, mais profundamente que os cristais formados pelos derivados do oxalato de potássio. Essas características explicam a redução da filtração dentinária em níveis inferiores comparativamente aos géis à base de oxalato de potássio, cujos cristais representavam, via de regra, o tamponamento mecânico dos túbulos dentinários.

\subsubsection{Microanálise de Raios $X$}

A microanálise de raios $X$ assim como a difração, são testes que têm auxiliado de alguma maneira na compreensão dos produtos da reação de diferentes materiais com o substrato dentinário. Na literatura, os autores ${ }^{69,124}$ comumente relatam sobre a dificuldade de interpretação das microanálises de raios $X$ devido, especialmente, a falhas na detecção de componentes presentes em pequenas quantidades. A dificuldade persiste quando são analisados os espectros dos resultados que podem apresentar sobreposição de picos decorrentes de elementos presentes em maior quantidade ou proximidade na amostra, ou a dificuldade de se diferenciar os elementos do espécime daqueles próprios do porta-amostra ou da cobertura condutora.

Desde que o principal componente da dentina é o fosfato de cálcio, é natural que os componentes mais encontrados nesse estudo sejam o cálcio, fósforo e oxigênio, comuns de 
serem observados nesse tipo de análise da dentina ${ }^{69}$. O potássio e o flúor não apareceram em nenhum dos espectros porque, provavelmente, ambos aparecem em menor quantidade. Segundo Hals, Tveit e $\operatorname{Totdal}^{86}$, em 1988, as áreas peritubulares da dentina coronária são mais mineralizadas, apresentando maior quantidade de cálcio, fósforo e magnésio. As altas concentrações de flúor e potássio freqüentemente aparecem em superfícies muito mineralizadas (esclerosadas), próximas a lesões cariosas ${ }^{86}$. Também Jain et al. ${ }^{104}$, em 1997, ao realizar a microanálise de raios $X$ de materiais de diferentes naturezas aplicados na dentina, encontraram essencialmente os componentes da dentina, cálcio, fósforo e oxigênio, sem diferenças do grupo controle. Zaimoglu e Aydin ${ }^{285}$, em 1992, realizaram a microanálise dos smear plugs após a aplicação de fluoreto de sódio, demonstrando um espectro característico da superfície dentinária, com proporções de cálcio o fósforo quase idênticas e sem detectar flúor.

Essas observações coincidem parcialmente com os dados obtidos da microanálise de raios $\mathrm{X}$ no presente trabalho. Aqui observa-se também espectros correspondentes à existência de cálcio, fósforo e oxigênio típicos da dentina. Porém, um aspecto importante se ressalta dessas observações. As microanálises pontuais de raios $\mathrm{X}$ revelaram baixos traços correspondentes ao oxigênio nas áreas da dentina livres de cristais. A mesma análise pontual realizada sobre os cristais revelou aumento dos picos de oxigênio, comparativamente à situação anterior. Isso pode revelar que os cristais, teoricamente estruturas de oxalato de cálcio, tenham naturalmente maiores concentrações de oxigênio que a superfície dentinária. As amostras tratadas com Gel Fluoretado não detectaram a presença de flúor. Os espécimes tratados com oxalato de potássio apresentaram o dobro do valor de oxigênio encontrado naqueles tratados com flúor, quando submetidos à análise semiquantitativa. 


\subsubsection{Difração de Raios $X$}

Diferentemente da microanálise, os testes de difração de raios $X$ permitem 0 reconhecimento aproximado dos compostos que fazem parte do substrato dentinário ou de sua interação com outros materiais. A exata forma molecular com a qual os vários elementos estão presentes nos cristais dos tecidos mineralizados é controversa. Muitas estruturas tem sido sugeridas, mas surge a dificuldade de escolher entre elas, pois suas fórmulas empíricas e propriedades como solubilidade, índice de refração e padrões de difração de raios $X$ das várias substâncias sugeridas não são similares. Uma das razões para essa dificuldade de identificação molecular dos cristais é que as apatitas biológicas são não-estoiquiométricas e sofrem constantes alterações por adsorção e trocas iônicas ${ }^{106}$.

As análises de difração de raios $\mathrm{X}$ podem ser feitas empregando-se pó de dentina ou os próprios fragmentos dentinários, tratados com os diferentes agentes. Mongiorgi et al. ${ }^{141}$, em 1992 e Mongiorgi e Prati ${ }^{144}$, em 1994, verificaram, por meio de ensaios de difração de raios $\mathrm{X}$ na dentina transformada em pó e tratada com oxalato de potássio a $30 \%$, a deposição de quantidades detectáveis, mas não abundantes, de oxalato de cálcio. A morfologia dos cristais demonstra a presença de partículas iso-orientadas, por isso poucas reflexões puderam aparecer.

A análise de difração de raios $X$ realizada no presente trabalho, utilizando como substrato o pó de dentina, trouxe informações semelhantes àquelas registradas pelos autores acima citados, isto é, não foi possível detectar precipitados de oxalato de cálcio, o principal produto de reação do oxalato de potássio com a dentina. Entretanto, pôde-se observar fluoreto de cálcio quando se empregou pó de dentina tratado com o Gel Fluoretado.

Quando a mesma análise foi realizada sobre os discos de dentina, a reatividade desse substrato com os géis experimentais em comparação com o pó mostrou resultados 
mais completos, isto é, encontrou-se oxalato de cálcio di-hidratado nos espécimes tratados com Oxa-Gel e Gel Experimental 2, e fluoreto de cálcio naqueles tratados com o Gel Fluoretado. Outros trabalhos na literatura relatados na publicação de Pashley ${ }^{159}$, em 1988, têm demonstrado a baixa reatividade do oxalato de potássio com a dentina em pó, provavelmente pela dispersão da solução ou do gel ao redor das partículas de dentina e pela menor área real de contato para reação. Além disso, quando o dente é pulverizado, as partículas oriundas de todas as regiões da coroa são misturadas, podendo fornecer um substrato com composição mineral diferente daquela oferecida pelo disco de dentina intacto. Sabe-se, ainda, que o oxalato de potássio quando é posto em contato por um minuto com a superfície de discos de dentina livres de smear layer, $60 \%$ do cálcio é adsorvido na superfície e $40 \%$ no interior dos túbulos. Quando o experimento é repetido na presença da smear layer, cerca de $84 \%$ do cálcio é adsorvido na superfície pela smear layer, deixando apenas $16 \%$ para ser adsorvido no interior dos túbulos ${ }^{159}$. Esses experimentos indicam a reatividade da smear layer e a habilidade dos túbulos de interagirem com os solutos que passam através deles, caracterizando a maior reatividade da estrutura dentinária completa em comparação com o pó de dentina.

Basicamente, as diferenças entre as três formulações de oxalato de potássio residem na concentração e no pH. Como o Oxa-Gel e o material Experimental 1 possuem $\mathrm{pH}$ semelhantes, a diferença entre eles está na concentração que varia de $3 \%$ para $6 \%$, respectivamente. Pode-se sugerir que o material Experimental 1 na concentração de $6 \%$ provoca alteração da força iônica com relação ao substrato dentinário resultando na formação de fosfato de cálcio e resíduos de oxalato de potássio penta-hidratado ao invés de cristais de oxalato de cálcio di-hidratado e fosfato de cálcio potássio, como formados pelo Oxa-Gel e pelo material Experimental 2. Por outro lado, Oxa-Gel e material Experimental 2 apresentam concentrações semelhantes (3\%), porém com pH 4 e 2 , respectivamente. $\mathrm{O}$ pH mais baixo do material Experimental 2 é, provavelmente, a causa principal de sua maior reatividade com o substrato dentinário resultando na precipitação de cristais de oxalato de 
cálcio di-hidratado e fosfato de cálcio potássio independente da condição em que foi experimentado.

A interpretação das diferentes etapas do presente trabalho e a interação das informações delas resultantes permitem considerar, em última análise, que os baixos índices de condutividade hidráulica da dentina tratada com os géis de oxalato de potássio encontram correspondência com os resultados de precipitação de compostos sobre a dentina e no interior dos túbulos, observados por meio da microscopia eletrônica de varredura, da microanálise de raios $\mathrm{X}$ e da difração de raios $\mathrm{X}$. Em contrapartida, o pequeno efeito do Gel Fluoretado na redução da permeabilidade dentinária não pode ser relacionada com a presença proporcional de depósitos cristalinos, uma vez que estes foram muito escassos quando observados em microscopia eletrônica de varredura. Sabe-se, entretanto, da ocorrência de precipitação de fluoreto de cálcio, provavelmente em quantidades muito pequenas, como evidenciado nas análises de difração de raios $\mathrm{X}$ e mais profundamente em dentina dificultando a visualização em microscopia eletrônica de varredura.

Fica, ainda, evidente que todas as formulações experimentadas alteraram o padrão de permeabilidade da dentina em um experimento de laboratório que deverá ser extrapolado para a realidade clínica com a devida consideração das diferenças e da fisiologia do complexo dentinopulpar. A experiência com esses agentes empregados clinicamente mostra que são efetivos no controle da hiperestesia ${ }^{205,206}$. A confrontação dos resultados clínicos e laboratoriais evidencia a dificuldade de simular laboratorialmente a multifatoriedade que envolve hiperestesia dentinária.

Assim, os agentes que conferem uma resposta positiva laboratorialmente, isto é, uma oclusão dos túbulos dentinários significativa, são facilmente identificados como agentes que podem ser efetivos clinicamente. Os agentes que não bloqueiam os túbulos dentinários dos discos de dentina podem, ainda, ser efetivos in vivo, desde que possam operar via outro mecanismo de oclusão tubular, ou bloquear os túbulos in vivo por um mecanismo que não 
pode ser simulado em modelos de laboratório ${ }^{124}$. Portanto, a extrapolação para situações clínicas da interpretação das modificações observadas in vitro precisa ser feita com cautela. 
Conclusões 


\section{Conclusões}

Baseados nos resultados obtidos, pode-se concluir:

\section{1. com relação à Condutividade Hidráulica:}

7.1.1. todas as formulações sob os diferentes pré-tratamentos de superfície estudados, com exceção do Gel Fluoretado, reduziram o índice de filtração através da dentina para níveis similares àqueles obtidos na presença da smear layer;

7.1.2. quanto maior o poder obstrutivo do Oxa-Gel e do material Experimental 1, mais notável foi o efeito do desafio ácido, com exceção do material Experimental 2 que apresentou boa obstrução e boa resistência ao ácido, e diferente do Gel Fluoretado que mostrou pouco poder obstrutivo e pouca diferença na filtração do líquido após o desafio ácido;

7.1.3. o material Experimental 2 alcançou o índice mais baixo de filtração dentinária, independentemente do pré-tratamento de superfície, seguido do Oxa-Gel, do material Experimental 1 e do Gel Fluoretado;

7.1.4. as formulações de oxalato de potássio mostraram melhor desempenho nas dentinas secas com ar, secas com papel e molhada. O Gel Fluoretado teve melhor desempenho quando aplicado na dentina seca com ar;

7.1.5 entre os pré-tratamentos de superfície, a dentina seca com ar mostrou o índice mais baixo de filtração de fluido, independentemente do material utilizado, seguida pela dentina seca com papel e molhada;

7.1.6 material Experimental 2 foi o menos sensível às variações do pré-tratamento da superfície dentinária e o Oxa-Gel foi o material que sofreu maiores alterações, mostrando melhor desempenho quando a dentina foi seca com ar e pior quando a dentina foi previamente acidificada; 


\section{2. com relação às análises de Microscopia Eletrônica de Varredura:}

7.2.1. os agentes anti-hiperestésicos apresentaram padrão de precipitação cristalina similar nas aberturas tubulares assim com no seu interior, com exceção do Gel Fluoretado que apresentou escassa deposição dentro dos túbulos e ausência de precipitação cristalina nas aberturas tubulares;

7.2.2. o Oxa-Gel foi o material que produziu obstrução das aberturas tubulares a índices mais próximos daqueles obtidos pela smear layer, seguido pelo Experimental 1, Experimental 2 e pelo Gel Fluoretado;

7.2.3. observou-se, invariavelmente para todos os materiais, a ampliação das áreas não obstruídas após o desafio com ácido cítrico. Entretanto, o Oxa-Gel mostrou maior resistência à desobstrução, seguido pelo Experimental 1, Experimental 2 e pelo Gel Fluoretado;

7.2.4. no interior dos túbulos dentinários, foram observadas deposições cristalinas formadas pelos derivados do oxalato de potássio com tamanho e profundidade similares; o Gel Fluoretado mostrou uma precipitação escas sa de cristais de menor tamanho e a uma maior profundidade no interior dos túbulos;

\section{3. com relação à Microanálise de Raios $X$ :}

7.3.1 os elementos cálcio, fósforo e oxigênio eram comuns aos cristais precipitados por quaisquer dos materiais anti-hiperestésicos estudados, sendo o cálcio em maior quantidade, seguido pelo fósforo e pelo oxigênio; 


\section{4. com relação à Difração de Raios $X$ :}

7.4.1. a presença de cristais de fluorapatita, hidroxiapatita, fosfato de potássio hidratado e fosfato de cálcio hidrogenado foram identificados tanto na dentina tratada com qualquer dos materiais anti-hiperestésicos quanto na dentina não tratada, independentemente das condições em que foram avaliados;

7.4.2. os materiais Oxa-Gel e Experimental 2 precipitaram cristais de oxalato de cálcio hidratado e fosfato de cálcio potássio;

7.4.3. ao contrário do esperado, o gel Experimental 1 não mostrou a presença de cristais de oxalato de cálcio hidratado, mas somente de fosfato de cálcio;

7.4.4. os cristais precipitados nos espécimes tratados com o Gel Fluoretado foram identificados como sendo de fluoreto de cálcio;

7.4.5. o pó de dentina não mostrou os mesmos padrões de precipitação cristalina observados para os discos de dentina, caracterizando-se como um substrato não apropriado para esse tipo de ensaio.

\section{5. com relação à Aplicabilidade Clínica}

Com base nas características de filtração da dentina e nas imagens de microscopia eletrônica de varredura, pode-se concluir ainda que as formulações à base de oxalato de potássio, especialmente o material Experimental 2 aplicado na dentina seca com ar, podem representar uma boa opção clínica para o tratamento da hiperestesia dentinária, diferentemente do Gel Fluoretado que demonstrou baixo poder obstrutivo e tênue deposição cristalina. 


\section{Referências Bibliográficas}




\section{Referências Bibliográficas}

1. ABSI, E. G.; ADDY, M.; ADAMS, D. Dentine hypersensitivity. A study of the patency of dentinal tubules in sensitive and non-sensitive cervical dentine. J. clin. Periodont., v.14, n.5, p.280-4, 1987.

2. ABSI, E. G.; ADDY, M.; ADAMS, D. Dentine hypersensitivity. The development and evaluation of a replica technique to study sensitive and non-sensitive cervical dentine. J. clin. Periodont., v.16, n.3, p.190-5, 1989.

3. ABSI, E. G.; ADDY, M.; ADAMS, D. Dentine hypersensitivity: uptake of toothpastes onto dentine and effects of toothbrushing, washing e dietary acid - SEM in vitro study. $\boldsymbol{J}$. oral Rehab., v.22, n.3, p.175-82, 1995.

4. ADDY, M.; MOSTAFA, P. Dentine hypersensibility I: effects produced by the uptake in vitro of metal ions fluoride and formaldehyde onto dentine. J. oral Rehab., v.15, n.6, p.575-85, 1988.

5. ADDY, M.; MOSTAFA, P.; ABSI, E. G.; ADAMS, D. Cervical dentin hypersensitivity. Etiology and management with particular reference to dentifrices. In: Proceedings of symposium on hypersensitive dentin. Origin and management. London, Livingstone Limited, 1985. p.147-67.

6. ADDY, M.; MOSTAFA, P.; NEWCOMBE, R. G. Dentine hypersensibility: the distribution of recession sensitivity and plaque. J. Dent., v.15, n.6, p.242-8, 1987.

7. ANDERSON, D. J.; MATTHEWS, B. An investigation into the reputed desensitizing effect of applying silver nitrate and strontium chloride to human dentine. Arch. oral Biol., v.11, n.11, p.1129-35, 1966.

8. ANDERSON, D. J.; MATTHEWS, B.; SHELTON, L. E. Variations in the sensitivity to osmotic simulation of human dentin. Arch. oral Biol., v.12, n.1, p.43-7, 1967.

\footnotetext{
Normas recomendadas para o uso no âmbito da Universidade de São Paulo, com base no documento "Referências Bibliográficas: exemplos", emanado do Conselho Supervisor do Sistema Integrado de Bibliotecas da USP, em reunião de 20 de setembro de 1990.
} 
9. AZEVEDO, V. M. N. N. Avaliação clínica de pacientes portadores de lesões dentárias cervicais não cariosas, relacionadas com alguns aspectos físicos, químicos e mecânicos da cavidade bucal. Bauru, 1994. 103p. Tese (Doutorado) Faculdade de odontologia de Bauru, Universidade de São Paulo.

10. BASSIOUNY, M. A.; POLLACK, R. L. Esthetic management of perimolysis with porcelain laminate veneers. J. Amer. dent. Ass., v.115, n.3, p.412-7, 1987.

11. BERGDTRÖM, J.; ELIASSON, S. Cervical abrasion in relation to tooth brushing and periodontal health. Scand. J. dent. Res., v.96, n.5, p.405-11, 1988.

12. BERMAN, L. H. Dentinal sensation and hypersensitivity-A review of mechanisms and treatment alternatives. J. Periodont., v.56, n.4, p.216-22, 1985.

13. BEVENIUS, J.; L'ESTRANGE, P.; ANGMAR-MANSSON, B. Erosion: guidelines for the general practioner. Aust. Dent. J, v.33, n.5, p.407-11, 1988.

14. BISSADA, N. J. Syntomatology and clinical features of hypersensitive teeth. Arch. oral Biol., v.39, p.31S-32S, 1994. Supplement.

15. BLOMLÖF, J.; BLOMLÖF, L.; LINDSKOG, S. Effect of different concentrations of EDTA on smear removal and collagen exposure in periodontitis-affected root surfaces. $J$. clin. Periodont., v.24, n.8, p.534-7, 1997.

16. BLONG, M. A. et al. Effects of a gel containing 0,4 percent stannous fluoride on dentinal hypersensitivity. Dent. Hyg., v.59, n.11, p.489-92, 1985.

17. BOKSMAN, L. et al. The treatment of perimolysis using resin bonded etched metal onlays. Quintessence Int., v.17, n.2, p.69-74, 1986.

18. BORRA, R. C. ImageLab: sistema de processamento e análise de imagens. São Paulo, Softium Informática. 1998. 85 p.

19. BOWERS, G. M.; ELLIOT, J. R. Topical use of prednisolone in periodontics. $\boldsymbol{J}$ Periodont., v.35, n., p.486, 1964.

20. BOZZOLA, J. J.; RUSSELL, L. D. Electron microscopy: principles and techniques for biologists. Toronto, Jones and Bartlett, 1998. 
21. BRADY, J. M.; WOODY, R. D. Scanning microscopy of cervical erosion. J. Amer. dent. Ass., v.94, n.4, p.726-9, 1977.

22. BRAEN, M.; LAMBRECHTS, P.; van HERLE, G. Stress-induced cervical lesions. J. prosth. Dent., v.67, n.5, p.718-22, 1992.

23. BRANDAU, H. E.; ZIEMIECKI,T. L.; CHARBENEAU, G. T. Restauration of cervical contorns on non prepared teeth using glass ionomer cement: 4 1/2 year report. $J$. Amer. dent. Ass., v.104, n.5, p.782-3, 1984.

24. BRÄNNSTRÖM, M. Dentin and pulp in restorative dentistry. London, Wolf Medical, 1982. p.22-37.

25. BRÄNNSTRÖM, M. Sensitivity of dentin. Oral Surg., v.21, n.4, p.517-26, 1966.

26. BRÄNNSTRÖM, M.; ASTRÖM, A. The hydrodynamics of the dentine; its possible relationship to dentinal pain. Int. dent. J., v.22, n.2, p.219-27, 1972.

27. BRÄNNSTRÖM, M.; GARBEROGLIO, R. The dentinal tubules and the odontoblast processes: a scanning electron microscopic study. Acta odont. scand., v.30, n.3, p.291-311, 1972.

28. BRÄNNSTRÖM, M.; ISACSSON, G.; JOHNSON, G. The effect of calcium hydroxide and fluorides on human dentine. Acta odont. scand., v.34, n.2, p.56-7, 1976.

29. BRÄNNSTRÖM, M.; JOHNSON, G. Effects of various conditioners and cleaning agents on prepared dentin surfaces: a scanning electron microscopic investigation. J. prosth. Dent., v.31, n.4, p.422-30, 1974.

30. BRÄNNSTRÖM, M.; JOHNSON, G.; LINDEN, L. A Fluid flow and pain response in the dentin produced by hydrostatic pressure. Odont. Revy, v.20, n.1, p.15-30, 1969.

31. BRÄNNSTRÖM, M.; JOHNSON, G.; NORDENVALL, K. J. Transmission and control of dentinal pain: resin impregnation for the desensitization of dentin. J. Amer. dent. Ass., v.99, n.4, p.612-8, 1979.

32. BRÄNNSTRÖM, M.; LINDEN, L. A.; ASTRÖM, A. The hydrodynamics of the dental tubule and of pulp fluid. A discussion of its significance in relation to dentinal sensitivity. Caries Res., v.1, n.4, p.310-7, 1967. 
33. BRÄNNSTRÖM, M.; NORDENVALL, K. J.; GLANTZ, P. O. The effect of EDTAcontaining surface-active solutions on the morphology of prepared dentin: an in vivo study. J. dent. Res., v.59, n.7, p.1127-31, 1980.

34. BURKE, F. J. T. et al. Contemporary concepts in the pathogenesis of the class $\mathrm{V}$ noncarious lesions. Dent. Update, v.22, n.1, p.28-32, 1995.

35. CAMPS, J. et al. Effects of pulsatile versus non-pulsatile pulpal pressure simulation on diffusional transport across human dentine in vitro. Arch. oral Biol., v.41, n.8/9, p.837-43, 1996.

36. CAMPS, J. et al. Influence of tooth criopreservation on human dentin permeability in vitro. Dent. Mat., v.10, n.3, p.210-4, 1994.

37. CAMPS, J. et al. Low versus high pressure for in vitro determination of hydraulic conductance of human dentine. Arch. oral Biol., v.42, n.4, p.293-8, 1997.

38. CARVALHO, Z.; DIAS, K. Avaliação da eficácia de três substâncias no tratamento da hipersensibilidade dentinária. In: Encontro do Grupo Brasileiro de Professores de Dentística, XIII, Recife, 1999. Anais. /Resumo $n^{\circ}$ 32/

39. CHABANSKI, M. B. et al. Prevalence of cervical dentine sensitivity in a population of patients referred to a specialist periodontology department. J. clin. Periodont., v.23, n.11, p.989-92, 1996.

40.CHARBENEAU, G. T.; BOZELL, R. R. Clinical evaluation of a glass ionomer cement for restoration of cervical erosion. J. Amer. dent. Ass., v.98, n.6, p.936-9, 1979.

41. CIUCCHI, B. et al. Clinical and histological observations of human teeth with cervically exposed dentine. Arch. oral Biol., v.39, p.148S, 1994. Supplement.

42. CIUCCHI, B. et al. Dentinal fluid dynamics in human teeth, in vivo. J. Endod., v.21, n.4, p.191-4, 1995.

43. COFFEY, C. T.; INGRAM, M. J.; BJORNDALL, A. Analysis of human dentinal fluid. Oral Surg., v.30, n.6, p.835-7, 1970.

44. COLLAERT, B.; FISCHER, C. Dentine hypersensitivity: a review. Endod. dent. Traumat., v.7, n.1, p.145-52, 1991. 
45. CONCEIÇÃO, E. N.; SCUR, A.; VIDOR, M. M. Avaliação clínica do uso de ionômero de vidro na hipersensibilidade dentinária cervical. Rev. bras. Odont., v.51, n.4, p.39-42, 1994.

46. COOLEY, R. L.; SANDOVAL, V. A. Effectiveness of potassium oxalate treatment on dentin hypersensitivity. Gen. Dent., v.37, n.4, p.330-3, 1989.

47. CUENIN, M. F. et al. An in vivo study of dentin sensitivity: the relation of dentin sensitivity and the patency of dentin tubules. J. Periodont., v.62, n.11, p.668-73, 1991.

48. CURRO, F. A. Tooth hypersensitivity in the spectrum of pain. Dent. Clin. N. Amer., v.34, n.3, p.429-37, 1990.

49. DALL'OROLOGIO, G. D. et al. Dentin desensitizing effects of gluma alternate, healthdent desensitizer and scotchbond multi-purpose. Amer. J. Dent., v.12, n.3, p.103-6, 1999.

50. DAVIDSON, D. F.; SUZUKI, M. The gluma bonding system: a clinical evaluation of its various components for the treatment for the hypersensitive root dentin. J. Canad. dent. Ass., v.63, n.1, p.38-41, 1997.

51. DIJKMAN, G. E. H. M. et al. Closing the dentinal tubules by glutaraldehyde treatment, a scanning electron microscopy study. Scand. J. dent. Res., v.102, n.3 , p.144-50, 1994.

52. DIPPEL, M.; BORGGREVEN, J. M P. M.; HOPPENBROUWERS, P. M. M. Morphology and permeability of the dentinal smear layer. J. prosth. Dent., v.52, n.5, p.657-62, 1984.

53. DOURDA, A. O.; MOULE, A. J.; YOUNG, W. G. A morphometric analysis of the crosssectional area of dentine occupied by dentinal tubules in human third molar teeth. Int. Endod. J., v.27, n.4, p.184-9, 1994.

54. DOWELL, P., ADDY, M. Dentine hypersensitivity: a review aetiology, symptoms and theories of pain production. J. clin. Periodont., v.10, n.4, p.341-50, 1983.

55. DOWELL, P., ADDY, M.; DUMMER, P. Dentine hypersensitivity: aetiology, differential diagnosis and management. Brit. dent. J., v.158, n.3, p.92-6, 1985. 
56. DRAGOLICH, W. E.; PASHLEY, D. H.; BRENNAN, W. A. An in vitro study of dentinal tubule occlusion by ferric oxalate. J. Periodont., v.64, n.11, p.1045-51, 1993.

57. ECCLES, J. D.; JENKINS, W. G. Dental erosion and diet. J. dent. Res., v.2, n.4, p.153-9, 1974.

58. EICK, J. D. et al. Scanning electron microscopy of cut tooth surface and identification of debris by use of the electron microprobe. J. dent. Res., v.49, ,n.6, p.1359-68, 1970. Supplement.

59. ESTRELA, C. et al. Análise da redução da dor pós-tratamento da hipersensibilidade dentinária. ROBRAC, v.6, n.17, p.4-9, 1996.

60. EVERETT, F. G., HALL, W. B.; PHATAK, N. M. Treatment of hypersensitive dentin. J. Oral Ther. Pharmacol., v.2, n.4, p.300-10, 1966.

61. FOGEL, H. M., PASHLEY, D. H. Effect of periodontal root planing on dentin permeability. J. clin. Periodont., v.20, n.9, p.673-7, 1993.

62. FOGEL, H. M.; MARSHALL, F. J.; PASHLEY, D. H. Effects of distances from the pulp and thickness on the hydraulic conductance of human radicular dentin. J. dent. Res., v.67, n.11, p.1381-5, 1988.

63. FOGEL, H. M.; PASHLEY, D. H. Dentin permeability: effects of endodontic procedures on root slabs. J. Endod., v.16, n.9, p.442-5, 1990.

64. GANGAROSA Sr., L. P. Current strategies for dentist-applied treatment in the management of hypersensitive dentine. Arch. oral Biol., v.39, p.101S-106S, 1994. Supplement.

65. GANGAROSA Sr., L. P.; PARK, N. H. Practical considerations in iontophoresis of fluoride for desensitizing dentin. J. prosth. Dent., v.39, n.2, p.173-8, 1978.

66. GARBEROGLIO, R.; BRÄNNSTRÖM, M. Scanning electron microscopic investigation of human dentinal tubules. Arch. oral Biol., v.21, n.6, p.355-62, 1976.

67. GARONE, W. Lesões cervicais e hipersensibilidade dentinária. In: Atualização na Clínica Odontológica. São Paulo: Artes Médicas, 1996. p.35-75. 
68. GEDALIA, L. et al. The effect of fluoride and strontium application on dentin: in vivo and in vitro studies. J. Periodont., v.49, n.5, p.269-72, 1978.

69. GILLAM, D. G. et al. Comparison of two desensitizing agents for the treatment of cervical dentine sensitivity. Endod. dent. Traumat., v.13, n.1, p.36-9, 1997.

70. GILLAM, D. G. et al. Efficacy of a potassium nitrate mouthwash in alleviating cervical dentine sensitivity. J. clin. Periodontol., v.23, n.11, p.993-7, 1996.

71. GILLAN, D. G.; BULMAN. J. S.; NEWMAN, H. N. A pilot assessment of alternative methods of quantifying dental pain with particular reference to dentine hypersensitivity. Community dent. HIth. , v.14, n.2, p.92-6, 1997.

72. GILLAN, D. G.; MORDAN, N. J.; NEWMAN, H. N. The dentin disc surface: a plausible model for dentin physiology and dentin sensitivity evaluation. Advanc. dent. Res., v.11, n.4, p.487-501, 1997.

73. GOODIS, H. E et al. Storage effects on dentin permeability and shear bond strength. Dent. Mater., v.9, p.79-84, 1993.

74. GOODIS, H. E. et al. Dentin surface modification by the Nd:YAG laser. Trans. Acad. Dent. Mater., v.2, p.246, 1989. /Abstract 019/

75. GOODIS, H. E.; TAO, L.; PASHLEY, D. H. Evaporative water loss from human dentine in vitro. Arch. oral Biol., v.35, n.7, p.523-7, 1990.

76. GOODIS, H. E; MARSHALL, G. W.; WHITE, J. M. Post-extraction history effects on dentin permeability. Archs. oral Biol., v.36, p.561-6, 1991.

77. GORMAN, W. J. Prevalence and etiology of gengival recession. J. Periodont., v.38, n.4, p.316-22, 1967.

78. GRAF, H.; GALASSE, R. Morbidity, prevalence and intra-oral distribution of hypersensitive teeth. J. dent. Res., v.56, p.162, 1977. Special Issue. /Abstract 479/.

79. GRANDO, L. J. Estudo in vitro da erosão causada por refrigerantes e suco de limão no esmalte de dentes decíduos humanos. Análises bioquímicas e morfológicas. Florianópolis, 1992. Dissertação (Mestrado) - Faculdade de Odontologia da Universidade Federal de Santa Catarina. 
80. GREEN, B. L.; GREEN, M. L.; MCFALL JUNIOR, W. T. Calcium hydroxide and potassium nitrate as desensitizing agents for hypersensitivity root surfaces. $J$. Periodont., v.48, n.10, p.667-72, 1977.

81. GREENHILL, J. D.; PASHLEY, D. H. The effects of desensitizing agents on the hydraulic conductance of human dentin in vitro. J. dent. Res., v.60, n.3, p.686-98, 1981.

82. GRIPPO, J. O. Abfraction: a new classification of hard tissues lesions of teeth. J. Esthet. Dent., v.3, n.1, p.14-9, 1991.

83. GRIPPO, J. O.; SIMRING, M. Dental erosion revisited. J. Amer. dent. Ass., v.126, n.5, p.619-28, 1995.

84. GROSSMAN, L. I. A systematic method for the treatment of hypersensitive dentin. J. $\boldsymbol{A m}$. Dent. Assoc., v.22, p.592-602, 1935.

85. HAHN, C.; OVERTON, B. The effects of immunoglobulins on the convective permeability of human dentine in vitro. Arch. oral Biol., v.42, n.12, p.835-43, 1997.

86. HALS, E.; TVEID, A. B.; TOTDAL, B. X-ray microanalysis of dentin: a review. Scanning Microsc., v.2, n.1, p.357-69, 1988.

87. HANSON, R. E.; BYE, F. L.; SMITH, B. A. Four different pain rating scales used to evaluated dentin hypersensitivity. J. dent. Res., v.67, p.282, 1988. Special Issue. /Abstract 1433/.

88. HAVEMAN, C. A.; CHARLTON, D. G. Dentin treatment with an oxalate solution and glass ionomer bond strength. Amer. J. Dent., v.7, n.5, p.247-51, 1994.

89. HELLSTRÖM, I. Oral complications in anorexia nervosa. Scand. J. dent. Res., v.85, n.1, p.71-86, 1977.

90. HEYMANN, H. O. Examining tooth flexure effects. J. Amer. dent. Ass., v.12, n.6, p.41-7, 1991.

91. HIRVONEN, T. J.; NÄRHI, M. V. O.; HAKUMÄKI, M. O. K. The excitability of dog pulp nerves in relation to the condition of the dentin surface. J. Endod., v.10, n.7 ,p.294-8, 1984. 
92. HODGKINSON, A. Oxalic acid in biology and medicine. London, Academic Press Inc., 1977. 323p.

93. HODOSH, M. et al. Potassium nitrate gel-sleeve: an effective procedure for dentinal hypersensitivity. Quintessence Int., v.13, n.11, p.1251-4, 1982.

94. HODOSH, M. A superior desensitizer - Potassium Nitrate. J. Amer. dent. Ass., v.88, n.4, p.831-2, 1974.

95. HODOSH, M.; HODOSH, S.; HODOSH, A. J. About dentin hypersensitivity. Comp. Continuing Educ. Dent., v.15, n.5, p.658-62, 1994.

96. HOLBOROW, D. W. A clinical trial of a potassium oxalate system in the treatment of sensitive root surfaces. Arch. oral Biol., v.39, p.134S, 1994. Supplement.

97. HOLLAND, G. R. et al. Guidelines for the design and conduct of clinical trials on dentine hypersensitivity. J. clin. Periodont., v.24, n.11, p.808-13, 1997.

98. HOLLAND, G. R. Morphological features of dentine and pulp related to dentine sensitivity. Arch. oral Biol., v.39, p.3S-11S, 1994. Supplement

99. HOTZ, P. R. Erosion des Zahnschmelzes. S S O, v.97, p.219-22, 1987.

100.IDE, M. The rôle of a dentine-bonding agent in reducing cervical dentine sensitivity. J. clin. Periodont., v.25, n.5, p.286-90, 1998.

101.IDE, M.; WILSON, R. F.; ASHLEY, F. P. Assessment of deposits formed on dentine components. Arch. oral Biol., v.39, p.150S, 1994. Supplement.

102.IP, T. et al. Quantification of dentinal tubules using image analysis: a laboratory study. J. dent. Res., v.76, p.180, 1997. Special Issue. /Abstract 1334/.

103. ISHIKAWA, K. et al. Occlusion of dentinal tubules with calcium phosphate using acidic calcium phosphate solution followed by neutralization. J. dent. Res., v.73, n.6, p.1197-204, 1994.

104.JAIN, P. et al. Dentin desensitizing agents: SEM and Xray microanalysis assessment. Amer. J. Dent., v.10, n.1, p.21-7, 1997. 
105.JÄRVINEN, V. K.; RYTÖMAA, I. I.; HEINONEN, O. P. Risk factors in dental erosion. J. dent. Res., v.70, n.6, p.942-7, 1991.

106.JENKINS, G. N. The physiology and biochemistry of the mouth. London, Blackwell Scientific Publications, 1978. 559p.

107.JOHNSON, G.; BRÄNNSTRÖM, M. The sensitivity of dentin. Changes in relation to conditions at exposed tubule apertures. Acta odont. scand., v.32, n.1, p.29-38, 1974.

108.JOHNSON, G.; OLGART, L.; BRÄNNSTRÖM, M. Outward fluid flow in dentin under a physiologic pressure gradient: experiments in vitro. Oral Surg., v.35, n.2, p.238-48, 1973.

109.JONES, R. R. H.; CLEATON-JONES, P. D. Depth and area of dental erosions, and dental caries in bulimic women. J. Dent. Res., v.68,, n.8, 1275-8, 1989.

110.KANAPKA, J. A. Over-the-counter dentifrices in the treatment of tooth hypersensitivity Review of clinical studies. Dent. Clin. N. Amer., v.34, n.3, p.545-60, 1990.

111.KAWASAKI, A. et al. Effects of hexafluorosilicate on the precipitate composition and dentine tubule occlusion by calcium phosphate. J. Dent., v.24, n.6, p.429-34, 1996.

112.KERNS, D. G. et al. Dentinal tubule occlusion and root hypersensitivity. J. Periodont., v.62, n.7, p.421-8, 1991.

113.KIM, S. Hypersensitive teeth: desensitization of pulpal sensory nerves. J Endod., v.12, n.10, p.482-5, 1986.

114.KNIGHT, N. N. et al. Hypersensitive dentin: testing of procedures for mechanical and quimical obliteration of dentinal tubuli. J. Periodont., v.64, n.5, p.366-73, 1993.

115.KRAUSER, J. T. Hypersensitive teeth. Part I: etiology. J. prosth. Dent., v.56, n.2, p.153$6,1986$.

116.KRAUSER, J. T. Hypersensitive teeth. Part II: treatment. J. prosth. Dent., v.56, n.3, p.307-11, 1986. 
117.LAN, W.; LIU, H.; LIN, C. The combined occluding effect of sodium fluoride varnish na Nd:YAG laser irradiation on human dentinal tubules. J. Endod., v.25, n.5, p.424-6, 1999.

118.LAWSON, B. F.; HUFF, T. W. Desensitization of teethwith a topically applied glucocorticoid drug: a preliminnary study. J. Oral Ther. Pharmacol., v.2, n.4, p.2959, 1966.

119.LEE, W. C.; EAKLE, W.S. Possible role of tensile stress in the etiology of cervical erosive lesions of teeth. J. prosth. Dent., v.52, n.3, p.374-80, 1984.

120.LEE, W. C; EAKLE, W. S. Stress-induced cervical lesions: review of advances in the past 10 years. J. prosth. Dent., v.75, n.5, p.487-94, 1996.

121.LEGEROS, R. Z. Calcium phosphates in oral biology and medicine. In: Monographs in oral science. Basel, Karger, 1991., v.15, 201p.

122.LEVIN, M. P.; YEARWOOD, L. L.; CARPENTER, W. N. The desensitizing effect of calcium hydroxide and magnesium hydroxide on hypersensitive dentin. Oral Surg., v.35, n.5 p.741-6, 1973.

123.LEVITCH, L. C. et al. Non-carious cervical lesions. J. Dent., v.22, n.4, p.195-207, 1994.

124.LING, T. Y. Y. et al. An investigation of potential desensitizing agents in the dentine disc model: a scanning electron microscopy study. J. oral Rehab. v.24, n.3, p.191-203, 1997.

125. LINKOSALO, E; MARKKANEN, H. Dental erosions in relation to lactovegerarian diet. Scand. J. dent. Res.,v.93, n.5, p.436-41, 1985.

126.LÖE, H.; ÄNERVERD, Ä; BOYSEN, H. The natural history of periodontal disease in man: prevalence, severity and extent of gingival recession. J. Periodont., v.63, n.6, p.489-95, 1992.

127.LUKOMSKY, E. H. Fluoride therapy for exposed dentin and alveolar therapy. J. dent. Res., v.20, n., p.649-59, 1941.

128.MAITA, E. et al. Fluid and protein flux across the pulpodentine complex of the dog in vivo. Arch. oral Biol., v.36, n.2, p.103-10, 1991. 
129.MARKOWITZ, K.; KIM, S. The effects of various ionic solutions on pulpal nerve sensitivity. J. dent. Res., v.64, p.309, 1985. Special Issue. /Abstract 1213/

130.MAROLI, S.; KHERA, S. C.; KRELL, K. V. Regional variation in permeability of young dentin. Oper. Dent., v.17, n.3, p.93-100, 1992.

131.MATTHEWS, W. G.; SHOWMAN, C. D.; PASHLEY, D. H. Air blast-induced evaporative water loss from human dentine, in vitro. Arch. oral Biol., v.38, n.6, p.517-23, 1993.

132. MCANDREW, R.; KOURKOUTA, S. Effects of toothbrushing prior and/or subsequent to dietary acid application on smear layer formation and the patency of dentinal tubules: an SEM study. J. Periodont. , v.66, n.6, p.443-8, 1995.

133.MEFFERT, R.M.; HOSKINS JUNIOR., S. W. Effect of a strontium chloride dentifrice in relieving dental hypersensitivity. J. Periodont., v.35, n., p.232-5, 1964.

134.MERCHANT, V. A.; LIVINGSTON, M. J.; PASHLEY, D. H. Dentin permeation: comparison of diffusion with filtration. J. dent. Res., v.56, n.10, p.1161-4, 1977.

135.MICHELICH, V.; PASHLEY, D. H.; WHITFORD, G. M. Dentin permeability: a comparison of functional versus anatomical tubular radii. J. dent. Res., v.57, n.11/12, p.1019-24, 1978.

136. MIDDA, M.; RENTON-HARPER, P. Lasers in Dentistry. Brit. dent J, v.170, n.9, p.343-6, 1991.

137.MINKOV, B. et al. The effectiveness of sodium fluoride treatment with and without iontophoresis on the reduction of hypersensitive dentin. J. Periodont., v.46, n.4, p.246-9, 1975.

138.MJÖR, I. A. Histologic studies of human coronal dentine following the insertion of various materials in experimentally prepared cavities. Arch. oral Biol., v.12, n.4, p.441-52, 1967.

139.MJÖR, I. A.; FURSETH, R. The inorganic phase of calcium hydroxide and corticosteroidcovered dentine studied by electron microscopy. Arch. oral Biol., v.13, n.7, p.75563, 1968. 
140.MJÖR, I. A.; NORDAHL, I. The density and branching of dentinal tubules in human teeth. Arch. oral Biol., v.41, n.5, p.401-12, 1996.

141.MONGIORGI, R. et al. Calcium oxalate smear layer: mineralogical and crystallographic study. Boll. Soc. It. Biol. Sper., v.68, n.2, p.99-103, 1992.

142.MONGIORGI, R. et al. Oxalate desensitizing treatment of dentinal surface. Boll. Soc. It. Biol. Sper., v.67, n.4, p.403-7, 1991.

143. MONGIORGI, R. et al. Oxalate solution and collagen-oxalate solution as protective liners for dentine. Boll. Soc. It. Biol. Sper., v.67, n.5, p.475-9, 1991.

144.MONGIORGI, R.; PRATI, C. Mineralogical and Crystallographical study of $\gamma$-cálcio oxalate on dentin surface in vitro. Arch. oral Biol., v.39, p.152S, 1994. Supplement.

145.MONGIORGI, R.; PRATI, C; FERRIERI, P. Effects of desensitizing toothpastes on dentine permeability. Arch. oral Biol., v.39, p.144S, 1994. Supplement.

146.MORDAN, N. J.; BARBER, P. M.; GILLAM, D. G. The dentine disc. A review of its applicability as a model for the in vitro testing of dentine hypersensitivity. J. oral Rehab., v.24, n.2, p.148-56, 1997.

147.MORITZ, A. Long-term effects of $\mathrm{CO}_{2}$ laser irradiation on treatment of hypersensitive dental neck: results of an in vivo study. J. Clin. Laser Med. Surg., v.16, n.4, p.2115,1998 .

148.MORRIS, M. F.; DAVIS, R. D.; RICHARDSON, B. W. Clinical efficacy of two dentin desensitizing agents. Amer. J. Dent., v.12, n.2, p.72-6, 1999.

149. MOSTELLER, J. H. Use of prednisolone in the elimination of postoperative thermal sensitivity. J. prosth. Dent., v.12, n., p.1176, 1962.

150.MUZZIN, K. B.; JOHNSON, R. Effects of potassium oxalate on dentin hypersensitivity in vivo. J. Periodont., v.60, n.3, p.151-8, 1989.

151.MYERS, T. D.; McDANIEL, J. D. The pulsed Nd:YAG dental laser: Review of clinical applications. J. Calif. dent. Ass., v.19, n.11, p.25-30, 1991. 
152.NAKABAYASHI, N.; PASHLEY, D. H. Hybridization of dental hard tissues. Quintessence, p.21-35, 1998.129p

153.NORDENVALL, K-L; BRÄNNSTRÖM, M. In vivo resin impregnation of dentinal tubules. J. prosth. Dent., v.44, n.6, p.630-7, 1980.

154.ORCHARDSON, R. et al. Dentine hypersensitivity into the $21^{\text {st }}$ century. Arch. oral Biol., v.39, p113S-119S, 1994. Supplement.

155.ORCHARDSON, R.; COLLINS, W. J. N. Clinical features of hypersensitive teeth. Brit. dent. J., v.162, n.7, p.253-6, 1987.

156.OUTHWAITE, W. C.; LIVINGSTON, M. J.; PASHLEY, D. H. Effects of changes in surface area, thickness, temperature and post-extraction time on human dentine permeability. Arch. oral Biol., v.21, n.10, p.599-603, 1976.

157.OUTHWAITE, W. C.; MCKENZIE, D. M.; PASHLEY, D. H. A versatile split-chamber device for studying dentin permeability. J. dent. Res., v.53, n.6, p.1503, 1974.

158.OYAMA, T.; MATSUMOTO, K. A clinical and morphological study of cervical hypersensitivity. J. Endod., v.17, n.10, p.500-2, 1991.

159.PASHLEY, D. H. Consideration of dentine permeability in cytotoxicity testing. Int. Endod. J., v.21, n.2 , p.143-54, 1988.

160.PASHLEY, D. H. et al. Dentin: a dynamic substrate - A review. Scanning Microsc. Int., v.3, n.1, p.161-76, 1989.

161.PASHLEY, D. H. et al. Regional variability in the permeability of human dentine. Arch. oral Biol.. v.32, n.7, p.519-23, 1987.

162.PASHLEY, D. H.; CARVALHO, R. M. Dentine permeability and dentine adhesion. J. Dent., v.25, n.5, p.355-72, 1997.

163.PASHLEY, D. H. Dentin permeability and dentin sensitivity. Proc. Fin. dent. Soc., v.88, p.31-7, 1992. Supplement 1.

164.PASHLEY, D. H. Dentin permeability, dentin sensitivity, and treatment through tubule occlusion. J. Endod., v.12, n.10, p.465-74, 1986. 
165.PASHLEY, D. H. Dentine permeability and its role in the pathobiology of dentine sensitivity. Arch. oral Biol., v.39, p.73S-80S, 1994. Supplement.

166.PASHLEY, D. H. Dentine permeability: theory and practice. In: Experimental endodontics. Spangberg, LSW. ed. Boca Raton, FL, CRC Press, 1990.

167.PASHLEY, D. H. et al. Comparison of in vitro and in vivo dog dentin permeability. J. dent. Res., v.60, n.3, p.763-8, 1981.

168.PASHLEY, D. H. et al. Dentin permeability. Effects of desensitizing dentifrices in vitro. J. Periodont., v.55, n.9, p.522-5, 1984.

169.PASHLEY, D. H. et al. Fluid shifts across human dentin in vitro in response to hydrodynamic stimuli. Arch. oral Biol., v.41, n.11, p.1065-72, 1996.

170.PASHLEY, D. H. et al. Progressive decrease in dentine permeability following cavity preparation. Arch. oral Biol., v.28, n.9, p.853-8, 1983.

171.PASHLEY, D. H. et al. Scanning electron microscopy of the substructure of smear layers in human dentine. Arch. oral Biol., v.33, n.4, p.265-70, 1988.

172.PASHLEY, D. H. et al. The effect of dentine permeability of time following cavity preparations in dogs. Arch. oral Biol., v.29, n.1, p.65-8, 1984.

173.PASHLEY, D. H. et al. The effects of acid-etching on the in vivo permeability of dentine in the dog. Arch. oral Biol., v.28, n.7, p. 555-9, 1983.

174.PASHLEY, D. H. et al. The effects of the degree of tubule occlusion on the permeability of human dentine in vitro. Arch. oral Biol., v.23, n.12, p.1127-33, 1978.

175.PASHLEY, D. H. Mechanism of dentin sensitivity. Dent. Clin. N. Amer., v.34, n.3, p.44973, 1990.

176.PASHLEY, D. H. Smear layer: overview of structure and function. Proc. Fin. dent. Soc., v.88, p.215-24, 1992. Supplement 1.

177.PASHLEY, D. H. Smear layer: physiological considerations. Oper. Dent., p.13-29, 1984. Supplement 3. 
178.PASHLEY, D. H. The influence of dentin permeability and pulpal blood flow on pulpal solute concentrations. J. Endod., v.5, n.12, p. 355-61, 1979.

179.PASHLEY, D. H.; ANDRINGA, H. J.; EICHMILLER, F. Effects of ferric and aluminum oxalates on dentin permeability. Amer. J. Dent., v.4, n.3, p.123-6, 1991.

180.PASHLEY, D. H.; DEPEW, D. D. Effects of the smear layer, copalite, and oxalate on microleakage . Oper. Dent., v.11, n.3, p.95-102, 1986.

181.PASHLEY, D. H.; GALLOWAY, S. E. The effects of oxalate treatment on the smear layer of ground surfaces of human dentine. Arch. oral Biol., v.30, n.10, p.731-7, 1985.

182.PASHLEY, D. H.; GALLOWAY, S. E.; STEWARD, F. Effect of fibrinogen in vivo on dentine permeability in the dog. Arch. oral Biol., v.29, n.9, p.725-8, 1984.

183.PASHLEY, D. H.; KALATHOOR, S.; BURNHAM, D. The effects of calcium hydroxide on dentin permeability. J. dent. Res., v.65, n.3, p.417-20, 1986.

184.PASHLEY, D. H.; LEIBACH, J. G.; HORNERT, J. A. The effects of burnishing $\mathrm{NaF/Kaolin/Glycerin} \mathrm{paste} \mathrm{on} \mathrm{dentin} \mathrm{permeability.} \mathrm{J.} \mathrm{Periodont.,} \mathrm{v.58,} \mathrm{n.1,} \mathrm{p.19-23,}$ 1987.

185.PASHLEY, D. H.; LIVINGSTON, M. J. Effect of molecular size on permeability coefficients in human dentine. Arch. oral Biol., v.23, n.5, p.391-5, 1978.

186.PASHLEY, D. H.; LIVINGSTON, M. J.; GREENHILL, J. D. Regional resistances to fluid flow in human dentine in vitro. Arch. oral Biol., v.23, n.9, p.807-10, 1978.

187.PASHLEY, D. H.; LIVINGSTON, M. J.; OUTHWAITE, W. C. Rate of permeation of isotopes through human dentin, in vitro. J. dent. Res., v.56, n.1, p.83-8, 1977.

188.PASHLEY, D. H.; LIVINGSTON, M. J.; WHITFORD, G. M. The effect of molecular size on reflection coefficients in human dentin. Arch. oral Biol., v.24, n.3, p.455-60, 1979.

189.PASHLEY, D. H.; MATTHEWS, W. G. The effects of outward forced convective flow on inward diffusion in human dentine in vitro. Arch. oral Biol., v.38, n.7, p.577-82, 1993. 
190.PASHLEY, D. H.; MICHELIN, V.; KEHL T. Dentin permeability: effects of smear layer removal. J. prosth. Dent., v.46, n.5, p.531-7, 1981.

191.PASHLEY, D. H.; NELSON, R.; KEPLER, E. E. The effects of plasma and salivary constituents on dentin permeability. J. dent. Res., v.61, n.8, p.978-81, 1982.

192.PASHLEY, D. H.; NELSON, R.; PASHLEY, E. L. In-vivo fluid movement across dentine in the dog. Arch. oral Biol., v.26, n.9, p.707-10, 1981.

193.PASHLEY, D. H.; NELSON, R.; WILLIAMS, E. C. Dentin hydraulic conductance: changes produced by red blood cells. J. dent. Res., v.60, n.10, p.1797-1802, 1981.

194.PASHLEY, D. H.; STEWART, F. P.; GALLOWAY, S. E. Effects of air-drying in vitro on human dentine permeability. Arch. oral Biol., v.29, n.5, p.379-83, 1984.

195.PASHLEY, D. H.; TAO, L.; PASHLEY, E L. Sterilization of human teeth: Its effects on permeability and bond strength. Amer. J. Dent., v.6, n.4, p.189-91, 1993.

196.PASHLEY, D. H.; THOMPSON, S. M.; STEWART, F. P. Dentin permeability: effects of temperature on hydraulic conductance. J. dent. Res., v.62, n.9, p.956-9, 1983.

197.PASHLEY, D. H.; WHITFORD, G. M. Permeability of human dentine in vitro interpreted from reflection coefficients. Arch. oral Biol., v.25, n.2, p.141-4, 1980.

198.PASHLEY, E. L. et al. Dentin permeability: sealing the dentin in crown preparations. Oper. Dent., v.17, n.1, p.13-20, 1992.

199.PASHLEY, E. L. et al. Effects of $\mathrm{CO}_{2}$ laser energy on dentin permeability. J. Endod., v.18, n.6, p.257-262, 1992.

200.PASHLEY, E. L. et al. Permeability of normal versus carious dentin. Endod. dent. Traumat., v.7, n.5, p.207-11, 1991.

201.PASHLEY, E. L.; TAO, L.; PASHLEY, D. H. Effects of oxalate on dentin bonding. Amer. J. Dent., v.6, n.3, p.116-8, 1993.

202.PEACOCK, J. M.; ORCHARDSON, R. Action potential conduction block of nerves in vitro by potassium citrate, potassium tartrate and potassium oxalate. J. clin. Periodont., v.26, n.1, p.33-7, 1999. 
203.PEREIRA, J. C. Hiperestesia dentinária. Aspectos clínicos e formas de tratamento. Maxi-Odonto Dentística, v.1, n.2, p.1-24, 1995. 24p.

204.PEREIRA, J. C. et al. Avaliação clínica de quatro métodos de dessensibilização dentinária. Relatório CNPq, processo n 802281/88-5, 1990.

205.PEREIRA, J. C. et al. Treatment of dentinal hypersensitivity in patients submitted to periodontal treatment. J. dent. Res., v.73, p.729, 1994. Special Issue. /Abstract 54/

206.PEREIRA, J. C.; MARTINELI, A. C. B. F. Treatment of hypersensitive dentin with different potassium oxalate formulations: a clinical study. J. dent. Res., v.78, p.251, 1999. Special Issue. /Abstract 1168/.

207.PEREIRA, J. C.; NICOLAU, M. R. Effect of potassium oxalate on dentin - SEM study. J. dent. Res., v.72, p.274, 1993. Special Issue. /Abstract 1367/.

208.PEREIRA, J. C.; SEGALA, A. D.; CARVALHO, R. M. Improving dentine reaction with potassium oxalate: S.E.M. study. J. dent. Res., v.75, p.197, 1996. Special Issue. /Abstract 1436/.

209.POLHAGEN, L.; BRÄNNSTRÖM, M. The liquid movement in desiccated and rehydrated dentine in vitro. Acta. odont. scand., v.29, n.1, p.95-102, 1971.

210.POWELL, L. V.; GORDON, G. E.; JOHNSON, G. H. Sensitive restored of Class V abrasion/erosion lesions. J. Amer. dent. Ass., v.121, n.6, p.694-6, 1990.

211.POWELL, L. V.; JOHNSON, G. H.; GORDON, G. E. Factors associated with clinical surfaces success of cervical abrasion/erosion restorations. Oper. Dent., v.20, n.1, p.7-13, 1995.

212.PRATI, C. et al. Effects of dentin surface treatments on the shear bond strength of Vitrabond. Dent. Mat., v.8, n.1, p.21-6, 1992.

213.PRATI, C. et al. Measurement of dentin permeability and wetness by use of the Periotron device. Dent. Mat., v.7, n.4, p.268-73, 1991.

214.PRATI, C. et al. Scanning electron microscopy and dentinal permeability analysis of smear layer. Boll. Soc. It. Biol. Sper., v.67, n.5, p.481-5, 1991. 
215.PRATI, C.; PASHLEY, D. H. Dentin wetness, permeability and thickness and bond strength of adhesive systems. Amer. J. Dent., v.5, n.1, p.33-8, 1992.

216.RANDENTZ, W. H.; BARNES, G. P.; CUTRIGHT, D. E. A survey of factors possibly associated with cervical abrasion of tooth surfaces. J. Periodont., v.47, n.3, p.148$54,1976$.

217.REEDER et al. Dentin permeability: determinants of hydraulic conductance. J. dent. Res., v.57, n.2, p.187-93, 1978.

218.REID, J. S., SIMPSON, M. S.; TAYLOR, G. S. The treatment of erosion using porcelain veneers. J. Dent. Child., v.58, n.4, p.289-92, 1991.

219.RICHARDSON, D. W.; TAO, L.; PASHLEY, D. H. Bond strength of luting cements to potassium-oxalate treated dentin. J. prosth. Dent., v.63, n.4, p.418-22, 1990.

220.RICHARDSON, D.; TAO, T.; PASHLEY, D. H. Dentin permeability: effects of crown preparation. Int. J. Prosth., v.4, n.3, p.219-25, 1991.

221.RIMONDINI, L.; BARONI, C.; CARRASSI, A. ultrastructure of hypersensitive and nonsensitive dentine. A study on replica models. J. clin. Periodont., v.22, n.12, p.899902, 1995.

222. ROSENTHAL, M. W. Historic review of the management of tooth hypersensitivity. Dent.

Clin. N. Amer., v.34, n.3, p.403-27, 1990.

223.RUSSO, E. M. A. Avaliação clínica de restaurações cervicais com cimento de ionômero de vidro. São Paulo, 1994. 138p. Tese (Doutorado) - Faculdade de Odontologia de São Paulo, Universidade de São Paulo.

224.RYTÖMAA, I. et al. In vitro erosion of bovine enamel caused by acidic drinks and other foodstuffs. Scand. J. dent. Res., v.96, n.4, p.324-33, 1988.

225.SANCHES, G. Traumatization of teeth and gengiva relates to habitual tooth changing procedures. J. clin. Periodont., v.3, n.2, p.94-103, 1976.

226.SANCHES, G.; GJERMO, P. Prevalence of oral soft and hard tissue lesions related to mechanical toothcleasing procedures. Community Dent. oral Epidem., v.4, n.2, p.77-83, 1976. 
227.SANTIAGO,S. L. Efeito de diferentes agentes anti-hiperestésicos, comercial e experimentais, sobre a permeabilidade dentinária em função do tempo pósaplicação. Bauru, 1999. 137p. Dissertação (Mestrado) - Faculdade de Odontologia de Bauru - Universidade de São Paulo.

228.SCHAEFFNER, M. et al. Epidemiology of dental erosion and tooth brush abrasion. J. dent. Res., v.66, p.388, 1988. Special Issue.

229.SCHAEFFNER, M. et al. The effectiveness of iontophoresis in reducing cervical hypersensitivity. J. Periodont., v.42, n.11, p.695-700, 1971.

230.SCHALLER, H. G.; WEIHING, T.; STRUB, J. R. Permeability of dentine after Nd:YAG laser treatment: an in vitro study. J. oral Rehab., v.24, n.4, p.274-81, 1997.

231.SELTZER, S. Dental conditions that cause head and neck pain. Pain control in Dentistry. Philadelphia, JB Lippincott, 1978. p.105-36.

232.SELTZER, S. Hypotetic mechanisms for dentine sensitivity. Oral. Surg., v.31, n.3, p.388-99, 1971.

233.SELTZER, S.; BENDER, I. B. The nerve supply of the pulp and pain perception. The Dental Pulp. Philadelphia, JB Lippincott, 1975. p.131-51.

234.SELTZER, S.; BOSTON, D. Hypersensitivity and pain induced by operative procedures and the "cracked tooth" syndrome. Gen. Dent., v.45, n.2, p.148-59, 1997.

235.SENA, F. J. Dentinal permeability in assessing therapeutic agents. Dent. Clin. $\boldsymbol{N}$. Amer., v.34, n.3, p.475-90, 1990.

236. SHAPIRO, W. B. et al. Controlled clinical comparison between a strontium chloride and a sodium monofluorophosphate toothpaste in diminishing root hypersensitivity. $J$. Periodont., v.41, n.9, p.523-25, 1970.

237.SHONO et al. A new oxalate treatment for dentine tubule occlusion. Arch. oral Biol., v.39, p.135S, 1994. Supplement.

238. SILVERMAN, G. et al. Assessing the efficacy of three dentifrices in the treatment of dentinal hypersensibility. J. Amer. dent. Ass., v.127, n.2, p.191-201, 1996. 
239.SIMPSON, M. D. et al. Effects of aluminum oxalate/glycine pretreatment solutions on dentin permeability. Amer. J. Dent., v.5, n.6, p.324-8, 1992.

240.SIMPSON, M. D.; CIARLONE, A. E.; PASHLEY, D. H. Effects of dentin primers on dentin permeability. J. dent. Res., v.72, n., p.127, 1993.

241.SOBRAL, M. A. P. Aspectos clínicos da etiologia da hipersensibilidade dentinária cervical e avaliação clínica de algumas técnicas de tratamento. São Paulo, 1997. 142p. Tese (Doutorado) - Faculdade de Odontologia de São Paulo, Universidade de São Paulo.

242.SPIGSET, O. Oral symptoms in bulimia nervosa. Acta odont. scand., v.49, n.6, p.3359, 1991.

243.STANLEY, H. R.; PEREIRA, J. C.; SPIEGEL, E. The detection and prevalence of reactive and fisiological sclerotic dentin, reparative dentin and dead tracts beneath various types of dental lesions according to tooth surface and age. J. oral Path., v.12, n.4, p.257-89, 1983.

244.STEAD, W. J.; ORCHARDSON, R.; WARREN, P. B. A mathematical model of potassium ion diffusion in dentinal tubules. Arch. oral Biol., v.41, n.7, p.679-87, 1996.

245.STEGE, P.; VISCO-DANGLER, L.; RYE, L. Anorexia nervosa: review including oral and dental manifestations. J. Amer. dent. Ass., v.104, n.5, p.648-52, 1982.

246.STEVENSON, T. S. Fluid movement in human dentine. Arch. oral Biol., v.10, n.6, p.935-44, 1965.

247.STRAWN, S. E. et al. Spectroscopic changes in human dentine exposed to various storage solutions - short term. J. Dent., v.24, n.6, p.417-23, 1996.

248.SUGE, T. et al. Duration of dentinal tubule occlusion formed by calcium phosphate precipitation method: in vitro evaluation using synthetic saliva. J. dent. Res., v.74, n.10, p.1709-14, 1995.

249.SUGE, T. et al. Effects of fluoride on the calcium phosphate precipitation method for dentinal tubule occlusion. J. dent. Res., v.74, n.4, p.1079-85, 1995. 
250.SUGE, T. et al. Evaluation of post-treatment solutions for clinical use with the calcium phosphate precipitation method. J. Dent., v.27, n.7, p.487-96, 1999.

251.SUGGS, A. K. Colloidal MSE for differential diagnosis and treatment of dentin hypersensitivity. In: Proceeding of International Conference on Dentin/Pulp Complex. Tokyo, Quintessence, 1996. p.245-7.

252.TAGAMI, J. et al. Effect of aging and caries on dentin permeability. Proc. Fin. dent. Soc., v.88, p.149-54, 1992. Supplement 1.

253.TAGAMI, J. et al. Effects of high-speed cutting on centin permeability and bonding. Dent. Mat., v.7, n.4, p.234-9, 1991.

254.TAGAMI, J.; NAKAJIMA, M.; HOSODA, H. Influence of dentin primers on fluid flow of bovine serum through dentin. Arch. oral Biol., v.39, p. 146S, 1994. Supplement.

255.TAGAMI, J.; TAO, L.; PASHLEY, D. H. Correlation among dentin depth, permeability, and bond strength of adhesive resins. Dent. Mat., v.6, n.1, p.45-50, 1990.

256.TAL, M. et al. X-ray diffraction and scanning electron microscope investigations of fluoride-treated dentine in man. Arch. oral Biol., v.21, n.5, p.285-90, 1976.

257.TAO, L.; PASHLEY, D. H.; BOYD, L. The effect of different types of smear layers on dentin and enamel bond strengths. Dent. Mat., v.4, n.4, p.208-16, 1988.

258.TARBET, W. J.; SILVERMAN, G.; STOLMAN, J. M. Clinical evaluation of a new treatment for dentinal hypersensitivity. J. Periodont., v.51, n.9, p.535-40, 1980.

259.TELLES, D. M. Prevalência de lesões cervicais não cariosas em estudantes de odontologia e sua relação com aspectos oclusais. Bauru, 1997 70p. Dissertação (Mestrado) - Faculdade de Odontologia de Bauru, Universidade de São Paulo.

260.THOMAS, H. F. The dentin-predentin complex and its permeability: anatomical overview. J. dent. Res., v.64, p.607-12, 1985. Special Issue.

261. THOMAS, H. F. The extent of odontoblastic process in human dentin. J. dent. Res., v.58, p.2207-18, 1979. Special Issue

262.THOMAS, H. F.; CARELA, P. Correlation of scanning and transmission electron microscopy of human dentinal tubules. Arch. oral Biol., v.29, n.8, p.641-6, 1984. 
263.THRASH, W. J.; JONES, D. L.; DODDS, W. J. M. Effect of a fluoride solution on dentinal hypersensibility. Amer. J. Dent., v.5, n.6, p.299-302, 1992.

264.TROWBRIDGE, H. O.; EDWALL, L. Effect of zinc oxide-eugenol and calcium hydroxide on intradental nerve activity. J. Endod., v.8, n.9, p.403-6, 1982.

265.TROWBRIDGE, H. O.; SILVER, D. R. A review o current approaches to in-office management of tooth hypersensitivity. Dent. Clin. N. Amer., v.34, n.3, p.561-81, 1990.

266.TSATSAS, B. G.; FRANK, R. M. Ultrastructure of the dentinal tubular substances near the dentino-enamel junction. Calcif. Tiss. Res., v.9, n.3, p.238-43, 1972.

267.TUNG, M. S. et al. Dentin desensitization by in situ formation of calcium phosphate. J. dent. Res., v.76, p. 387, 1997. Special issue. /Abstract 2985/.

268.TUNG, M. S. et al. Effects of calcium phosphate solutions on dentine permeability. J. Endod., v.19, n.8, p.383-7, 1993.

269.VONGSAVAN, N.; MATTHEWS, B. The relation between fluid flow through dentine and the discharge of intradental nerves. Arch. oral Biol., v.39, p.140, 1994. Supplement. /Abstract/.

270.WALKER, T. M.; JENSEN, M. E.; KILLIP, D. Evaluation of potassium oxalate cavity liner for glass ionomer restorations. J. dent. Res., v.66, p.212, 1987. /Abstract. 846/.

271.WATANABE, T. et al. The effects of primers on the sensitivity of dentin. Dent. Mat., v.7, n.3, p. $148-50,1991$.

272.WEST, N. X. et al. Dentin hypersensitivity and the placebo response. J. clin. Periodont., v.24, n.3, p.209-15, 1997.

273.WHITE, J.; GOODIS, H; ROSE, C. Efect of Nd:YAG laser treatment on hidraulic conductance of dentin. J. dent. Res., v.69, p.169, 1990. Special issue. /Abstract/.

274.WICHGERS, T. G.; EMERT, R. L. Dentin hypersensitivity. Gen. Dent., v.44, n.3, p. 22530, 1996.

275.WOTGenS, J. N. et al. Enamel erosion and saliva. Clin. Prev. Dent., v.7, n.3, p.8-10, 1985. 
276.XHONGA, F. A.; VAN-HERLE, A. The influence of hyperthyroidism on dental erosions. Oral Surg., v.36, n.3, p.349-57, 1973.

277.YAMAMOTO, $\mathrm{H}$. et al. precipitation of oxalates in dog dentinal tubules in vivo. In: Proceeding of International Conference on Dentin/Pulp Complex. Tokyo, Quintessence, 1996. p.278-9.

278.YATES, R. et al. A split-mouth placebo-controlled study to determine the effect of amorphous calcium phosphate in the treatment of dentine hypersensitivity. J. clin. Periodont., v.25, n.8, p.687-92, 1998.

279. YOSHIYAMA, M. et al. Morphological characterization of hypersensitive human radicular dentin and the effect of a light curing resin liner on tubular occlusion. Proc. Fin. dent. Soc., v.88, p.337-44, 1992. Supplement 1.

280. YOSHIYAMA, M. et al. Process-like structures in the tubules of hypersensitive human dentine. Arch. oral Biol., v.39, p.153S, 1994. Supplement.

281.YOSHIYAMA, M. et al. Regional strengths of bonding agents to cervical sclerotic root dentin. J. dent. Res., v.75, n.6 , p.1404-13, 1996.

282. YOSHIYAMA, M. et al. Scanning electron microscopic characterization of sensitive vs. insensitive human radicular dentin. J. dent. Res., v.68, n.11, p.1498-1502, 1989.

283.YOSHIYAMA, M. et al. Transmission electron microscopic characterization of hypersensitive human radicular dentin. J. dent. Res., v.69, n.6, p.1293-7, 1990.

284.YOSHIYAMA, M.; SUGE, T.; EBISU, S. Morphological characterization of tube-like structures in hypersensitive human radicular dentin. J. Dent.., v.24, n.1-2, p.57-63, 1996.

285.ZAIMOGLU, A; AYDIN, A. K. An evaluation of smear layer with various desensitizing agents after tooth preparation. J. prosth. Dent., v.68, n.3, p.450-7, 1992.

286.ZHANG, Y. et al. The effects of pain-free desensitizer on dentine permeability and tubule occlusion over time, in vitro. J. clin. Periodont., v.25, n.11, p.884-91, 1998.

287.ZHANG, C. Effects of $\mathrm{CO}_{2}$ laser in treatment of cervical dentinal hypersensitivity. J. Endod., v.24, n.9, p.595-7, 1998. 
Abstract 


\title{
Effect of potassium oxalate based dessensitizing agents on human dentin permeability. In vitro study.
}

\begin{abstract}
Potassium oxalate has been used to reduce dentin hypersensitivity. Studies have shown that the reaction of this salt with dentin substrate may result in calcium oxalate crystals deposits over and inside dentin tubules, reducing fluid filtration and dentin hypersensitivity. The aim of this study was to evaluate the variation of fluid filtration of dentin treated with different formulations of potassium oxalate gels, under five different pre-conditioned dentin surfaces It was used the method suggested by Pashley, Steward e Galloway (1984) for the measurement of hydraulic conductance of dentin. The dentin reaction with the gels were also evaluated by means of Scanning Electron Microscopy, X-Ray Microanalysis (EDS) and X-Ray Diffraction (XRD). Two hundred dentin discs $1 \mathrm{~mm}$ in thickness, obtained from human extracted third molars, were divided into 20 groups of ten specimens each. The groups corresponded to the following experimental materials: $3 \%$ potassium oxalate gel - $\mathrm{pH} 4 ; 6 \%$ potassium oxalate gel - $\mathrm{pH} 4 ; 3 \%$ potassium oxalate gel - $\mathrm{pH} 2,5$ and 1,23\% fluoride gel - $\mathrm{pH} 3,6-3,9$, applied to dentin under the following surface conditions: air-dried, blot dried, wet, acidic air-dried and acidic blot-dried.
\end{abstract}

Other 40 dentin discs were prepared for SEM analysis using the same experimental materials under one of the surface treatments studied in the hydraulic conductance. Dry dentin discs were then chosen for SEM and XRay studies. The specimens were divided in five groups of ten corresponding to the five materials used. The pattern of crystals deposition on the dentin surface and inside the tubules were assessed by SEM images and analyzed thought a digital analysis software. At the same time eight new dentin discs reproducing the same conditions as for SEM were prepared for EDS (Electron Dispersive Spectroscopy) in order to asses the elemental analysis of the crystals. Eighteen complementary discs were prepared for $\mathrm{X}$ Ray 
Diffraction Analysis for the study of the molecular composition of the crystals produced by the different experimental materials. This analysis was complemented with nine pellets of powdered dentin to compare the reactivity and the basic composition of dentin substrate. General MANOVA and post-hoc Duncan tests were performed on the dada of hydraulic conductance. Regardless of surface pre-treatment the $3 \%$ potassium oxalate gel - $\mathrm{pH} 2,5$ showed the lowest dentin filtration $(p<0,05)$ even after citric acid challenge. In general, air-drying the dentin was the best surface pre-treatment $(p<0,05)$. The interaction between the material and surface pretreatment showed values of hydraulic conductance similar for most of combinations, but the $3 \%$ potassium oxalate gel - $\mathrm{pH} 2,5$ under wet condition assumed the best tendency for filtration decreasing. The Fluoride Gel showed the weakest performance when compared with the other materials, regardless surface pre-treatment. The potassium oxalate gels used in this investigations significantly reduced dentin filtration.

MANOVA and Duncan tests were also performed to the SEM results and showed that the potassium oxalate gels precipitated crystals deposits over the dentin surface and inside the dentin tubules as well in statistically similar patterns. No crystals were seen on dentin surface in the specimens treated with Fluoride Gel, but only a few crystals inside the tubules. The range of crystal average penetration into the tubules was 7,52 to $9,41 \mu \mathrm{m}$. The X-Ray Microanalysis of crystals evidenced the presence of calcium, phosphorus and oxygen equally for the four materials used. The XRay Diffraction of the dentin discs evidenced the presence of calcium oxalate and calcium potassium phosphate. Calcium fluoride was observed in the specimens treated with Fluoride Gel. The dentin discs were more reactive with the materials studied then the dentin powdered specimens. One may conclude that the potassium oxalate gels studied in this investigation applied on dry dentin have a great potential for tubule occlusion and consequently a clinical applicability on dentin hypersensitivity. 